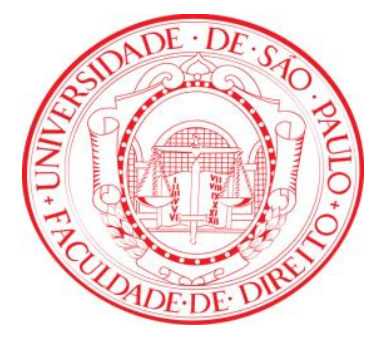

FÁBIO GUSMAN

A PRISÃo PREVENTIVA DE OFÍCIO: ANÁLISE CRÍTICA À LUZ DO SISTEMA CONSTITUCIONAL ACUSATÓRIO

Dissertação de Mestrado

Orientador: Professor Titular Dr. Antonio Magalhães Gomes Filho

UNIVERSIDADE DE SÃO PAULO

FACULDADE DE DIREITO

São Paulo-SP

2015 
FÁBIO GUSMAN

\section{A PRISÃO PREVENTIVA DE OFÍCIO: ANÁLISE CRÍTICA À LUZ DO SISTEMA CONSTITUCIONAL ACUSATÓRIO}

Dissertação apresentada à Banca Examinadora do Programa de Pós-Graduação em Direito, da Faculdade de Direito da Universidade de São Paulo, como exigência parcial para a obtenção do título de Mestre em Direito, na área de concentração Direito Processual sob orientação do Professor Titualr Dr. Antonio Magalhães Gomes Filho.

Versão corrigida em 8 de junho de 2015.

\section{UNIVERSIDADE DE SÃO PAULO \\ FACULDADE DE DIREITO \\ São Paulo-SP \\ 2015}


Para minha querida mãe. Para minha amada esposa.

Para meu saudoso avô. 


\section{AGRADECIMENTOS}

O presente trabalho não poderia ser realizado sem a concorrência de algumas pessoas especiais.

Minha querida esposa Carolina Oliboni Bastos e meu grande amigo Fábio Cordeiro Villar deram-me a oportunidade de ler os rascunhos e opinarem sobre o conteúdo de forma melhorar sensivelmente o texto.

Agradeço à Luiza Cristina Fonseca Frischeisen que me introduziu ao mundo do processo penal e incentivou minha matrícula do Centro de Estudios de Justicia de las Américas. Da mesma forma, agradeço à Mônica Nicida Garcia e ao Pedro Barbosa Pereira Neto, pela oportunidade que me concederam de continuar aprendendo junto a esta magnífica instituição que é o Ministério Público Federal.

Foram de grande valia as consultas que me concedeu meu amigo Paulo Thadeu Gomes da Silva, cujo acervo intelectual (tanto em sua mente quanto em sua biblioteca) parece inesgotável. Também auxiliou a encaminhar as ideias iniciais da dissertação a professora de processo penal Paula Bajer Martins da Costa.

Ao Professor Aury Lopes Jr. agradeço pela aula que me concedeu na discussão sobre meu tema em seu escritório de Porto Alegre. Suas observações foram de imensa importância para a estrutura da dissertação.

Agradeço ao Professor Antonio Magalhães Gomes Filho pela valiosa oportunidade de poder elaborar uma dissertação de mestrado sob sua orientação. Foram de grande valia, também, as observações do Professor Associado Gustavo Henrique Righi Ivahy Badaró e da Professora Doutora Marta Cristina Cury Saad Gimenes por ocasião da banca de qualificação do trabalho.

Sem a formação que tive no Centro de Estudios de Justicia de las Americas este trabalho nunca poderia ser levado a cabo. Dos meus companheiros de curso recebi aportes importantes. Agradeço, a Javier Gómez Cervantes, Juiz de Impugnação em 
Guanajuato, Hugo Antolin Almirón, Promotor e Professor da Universidad de Córdoba e Roberto Adrián Barrios, Juiz na Provincia de Chubut. Também ofereceram grande contribuição meus amigos Guillermo Nicora, promotor de Mar del Plata, Eduardo Gallardo, juiz em Santiago, Javier Ignacio Reyes Lopes, juiz em Valencia e a pesquisadora Letícia Lorenzo.

Agradeço aos meus amigos de trabalho no Ministério Público Federal que tornam prazeroso trabalhar todos os dias.

Obrigado a todos. 


\section{RESUMO}

\section{GUSMAN, Fábio. A prisão preventiva de ofício: análise crítica à luz do sistema}

constitucional acusatório. 2015. Dissertação de Mestrado. Faculdade de Direito da Universidade de São Paulo.

O presente trabalho tem como objetivo a análise da validade das normas infraconstitucionais que possibilitam ao julgador penal a decretação da prisão preventiva sem o requerimento do Ministério Público ou do querelante. O maior ou menor grau de atribuições de ofício ao juiz está diretamente ligado ao sistema processual penal vigente em cada jurisdição. Desta forma, importa definir os sistemas processuais penais acusatório, inquisitório e misto, os princípios que os regem, e identificar qual deles foi o escolhido pela Constituição Federal de 1988 e pelas normas supralegais. A partir da conclusão de que a Constituição Federal institui o princípio acusatório que condiciona todas as normas infraconstitucionais, identificamos as normas que não encontram sua fundamentação neste princípio e, por isso, destoam do sistema. A norma que dá ao juiz o poder de decretar de ofício a prisão preventiva é uma delas. O trabalho, então, analisa criticamente alguns dos argumentos que comumente são utilizados para fundamentar a posição da constitucionalidade ou inconstitucionalidade da norma, concluindo que as bases que sustentam o poder de ofício do juiz é o ideal inquisitório de um sistema de justiça que implementa políticas públicas em que a imparcialidade do juiz é um atributo de somenos importância. Por fim, colacionam-se algumas notas de direito comparado a respeito de como a questão é tratada em diferentes jurisdições. O trabalho conclui que o poder de decretar a prisão preventiva de ofício está em contradição com os valores processuais acusatórios típicos dos Estados Democráticos de Direito. Indica-se uma possível solução para a modernização do método de tomada de decisão de medidas cautelares consistente nas audiências prévias que oferecem um ambiente mais propício ao exercício das garantias processuais.

Palavras-chave: Processo penal, sistemas processuais penais, sistema inquisitório, sistema acusatório, prisão preventiva, poderes de ofício do juiz. 


\begin{abstract}
This study aims to analyze the validity of the infra-constitutional norms that allow the criminal judge to issue a remand without the request of the prosecutor or the plaintiff. The greater or lesser degree of power assigned to the judge is directly connected to the current actual justice system in each jurisdiction. Thus, it is relevant to define the criminal procedural systems accusatorial, inquisitorial and mixed, their governing principles, and identify which one was chosen by the Federal Constitution of 1988 and the rules that are higher in hierarchy. From the assumption that the Brazilian Constitution establishes the adversarial principle which determines norms in our law systems, the study identifies rules that do not find their justification in this principle and, therefore, diverge from the system. The rule that gives the judge the power to issue a preventive detention order is one of them. The work then critically examines some of the arguments that are commonly used to support the position of the constitutionality or unconstitutionality of this rule, concluding that the basis supporting the judge's power is the inquisitorial ideal of a policy implementing justice system in which the judge's impartiality is a minor attribute. Finally, some notes of comparative law are collected in regard to how the issue is assessed in different jurisdictions. The paper concludes that the power to issue the order is contrary to the typical values of the accusatory procedural law of Democratic States. At the end, the study indicates a possible solution to the modernization of the decision-making method for precautionary measures consistent in previous hearings that offer an environment more conducive to the exercise of procedural safeguards.
\end{abstract}

Key words: Criminal procedure, criminal procedure systems, inquisitorial system, accusatorial system, remand, preventive detention order, ex officio powers of the judge. 


\section{SUMÁRIO}

\section{INTRODUÇÃO}

\section{SISTEMAS PROCESSUAIS PENAIS}

1.1. Modelo acusatório

1.1.1. Delieneamento histórico

1.1.2. Características definidoras do sistema acusatório

1.1.2.1. A imparcialidade do juiz

1.1.2.2. A relevância do contraditório

1.1.2.3. Correlação entre acusação e decisão

1.1.2.4. Prisão preventiva como medida cautelar

1.1.2.5. Oralidade e simplificação dos ritos processuais

1.1.3. O sistema acusatório "puro" e o sistema do common Law

1.2. Modelo inquisitório

1.2.1. Delineamento histórico

1.2.2. O papel do juiz no sistema inquisitório

1.2.3. A importância da custódia cautelar processual e o processo como início de aplicação da pena

1.2.4. A noção de expediente escrito, burocrático, hierarquizado e secreto como caractaerísticas do sistema inquisitório

1.3. O modelo misto 


\section{A PRISÃO PREVENTIVA DE OFÍCIO NO BRASIL}

2.1. Breve delineamento histórico do processo penal brasileiro e da prisão preventiva

2.2. Plano da Constituição Federal de 1988

2.3. Plano atual das normas internacionais

2.4. Sentido das reformas das leis processuais penais: o reflexo do mandamento constitucional acusatório no plano infraconstitucional

3. ANÁlISE DOS ARGUMENTOS SOBRE A VALIDADE OU INVALIDADE DA DECRETAÇÃO DA PRISÃO PREVENTIVA DE OFÍCIO

3.1. Avanço e retrocesso

3.2. Argumento do interesse público e sua refutação

3.2.1. O impulso oficial

3.2.2. Poder geral de cautela do juiz penal

3.2.3. O princípio da obrigatoriedade

3.2.4. O requerimento implícito

3.3. A representação da polícia como uma provocação suficiente da jurisdição

3.4. A separação entre as fases "inquisitória" e "acusatória"

3.5. A inércia da jurisdição

3.6. O reflexo da prisão preventiva decretada de ofício na imparcialidade do julgador

3.7. Argumento do esvaziamento do contraditório

4. NOTAS SOBRE A PRISÃo CAUTELAR DE OFÍCIO NO DIREITO COMPARADO

4.1. Itália 
4.2. Espanha

4.3. Portugal

4.4. Chile

\section{CONCLUSÕES}

5.1. Inconstitucionalidade das normas que dispõe sobre a possibilidade de decretação de prisão preventiva de ofício por parte do juiz

5.2. Solução possível de acordo com o sistema acusatório

BIBLIOGRAFIA 
"La mayor virtud de un saber sobre el proceso penal debe consistir en la capacidad de orientar nuevas prácticas y ello solo lo logra si tiene, a su vez, capacidad de desplazar a los saberes anteriores."

Alberto M. Binder

"Juez y pena se encuentran siempre juntos" James Goldschmidt

"Cada vez que un imputado inocente tiene razón para temer a un juez, quiere decir que éste se halla fuera de la lógica del estado de derecho: el miedo, y también la sola desconfianza y la no seguridad del inocente, indican la quiebra de la función misma de la jurisdicción penal y la ruptura de los valores políticos que la legitiman" Luigi Ferrajoli

"Il provvedimento [cautelare] ex officio nasce nullo" Franco Cordero 


\section{INTRODUÇÃO}

Ao introduzir sua obra Era dos Direitos em 1990, Norberto Bobbio lembra teses fundamentais do Direito enunciadas em 1951 e das quais nunca se afastou: a) "os direitos naturais são direitos históricos"; b) "nascem no início da era moderna, juntamente com a concepção individualista da sociedade"; c) "tornam-se um dos

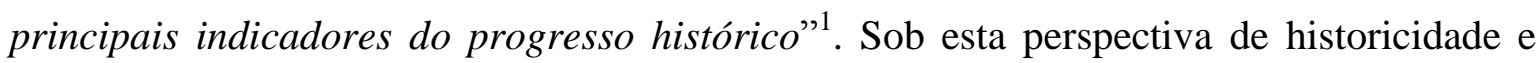
conquista dos direitos e garantias individuais, a presente monografia busca analisar um dispositivo específico do Código de Processo Penal vigente no Brasil que consiste na (im)possibilidade jurídica do decreto de ofício da prisão preventiva por parte do julgador, ou seja, sem requerimento de qualquer das partes. Para isso, partamos de premissas teóricas e normativas que permearão todo o estudo.

\footnotetext{
${ }^{1}$ BOBBIO, N. Era dos Direitos. p. 22.
} 
No esteio da gradual conquista de direitos $^{2}$, o movimento constitucionalista do ocidente partiu da ideia racional iluminista de limitação do poder, ou seja, de resguardo do indivíduo contra o Estado $^{3}$, de maneira que a Constituição - norma hierarquicamente superior - serve de parâmetro de validade jurídica a todo o sistema de normas de um dado ordenamento jurídico. Trata-se da aplicação do princípio da supremacia da Constituição, diploma que incorporou os direitos e garantias de tutela das liberdades públicas enunciados nos pactos internacionais de direitos humanos.

A Constituição brasileira atualmente vigente, promulgada após circunstâncias políticas e jurídicas autoritárias, representou a mudança de paradigma e o movimento de adequação de todo o ordenamento infraconstitucional aos superiores princípios e regras dispostos na nova Lei Maior.

Trabalhamos, então, com o direito processual penal como um direito constitucional aplicado ${ }^{4}$. Encontramos na Constituição Federal os preceitos fundamentais deste ramo do direito público que o situam como um fator limitador do poder punitivo estatal $^{5}$. Tais preceitos condicionam um modelo processual específico, um modelo de processo legítimo, um due process of $l a w^{6}$, em cuja arqueologia identificamos a limitação do poder estatal e o direito de defesa ${ }^{7}$. Por isso as leis processuais devem sempre ser

\footnotetext{
2 A tese está ancorada na ideia kantiana da tendência de progresso moral da humanidade expressada, dentre outros textos, em An old question raised again: is the human race constantly progressing? In KANT, I. The conflict of the faculties. p. 141. Para Kant, embora haja inegáveis momentos de retrocesso, a humanidade como um todo (universorum) caminha para dar a si mesma uma boa constituição. Cf. BOBBIO, N. op. cit. 66 e seguintes.

3 CANOTILHO, J.J.G. Direito Constitucional..., p. 51., define constitucionalismo como "teoria (ou ideologia) que ergue o princípio do governo limitado indispensável à garantia dos direitos em dimensão estruturante da organização político-social de uma comunidade".

${ }^{4}$ HASSEMER, W. Introdução aos fundamentos do Direito Penal. p. 172

${ }^{5}$ DIAS, J.F. Direito processual penal. p. 64/65. "Deste modo [elevando o acusado a sujeito do processo] $o$ direito processual penal torna-se em uma ordenação limitadora do poder do Estado em favor do indivíduo acusado, numa espécie de Magna Charta dos direitos e garantias individuais do cidadão. Pois o Estado, protegendo o indivíduo, protege-se a si próprio contra a hipertrofia do poder e os abusos no seu exercício."

${ }^{6}$ A mudança trazida pela Constituição de 1988 passou a exigir que o processo não mais fosse conduzido prioritariamente, conforme OLIVEIRA, E.P. Curso de Processo Penal. p. 8/9, "como mero veículo de aplicação da lei penal, mas, além e mais que isso, que se transformasse em um instrumento de garantia do individuo em face do Estado. $O$ devido processo penal constitucional busca, então, realizar uma Justiça Penal submetida à exigência de igualdade efetiva entre os litigantes. O processo justo deve atentar, sempre, para a desigualdade material que normalmente ocorre no curso de toda persecução penal, em que o Estado ocupa posição de proeminência, respondendo pelas funções investigatórias e acusatórias. Como regra, e pela atuação da jurisdição, sobre a qual exerce o monopólio".

${ }^{7}$ CANOTILHO, op. cit. p. 496. Cita-se também GRINOVER, A.P. Liberdades públicas. p. 15-21. "Mas se, do ponto de vista da persecução penal, os direitos do acusado se colocam como limite à função jurisdicional,
} 
produzidas e aplicadas à luz das normas que lhe dão validade: a Constituição Federal (bloco constitucional) e as normas internacionais supralegais definidoras dos direitos e garantias fundamentais.

Estas garantias do processo passaram a fazer parte da esfera individual ao longo de largo processo histórico de elaborações teóricas, lutas e conquistas que têm como marco o pensamento iluminista do século XVIII e definem, por si, o progresso das sociedades, como explica Bobbio na Era dos Direitos.

Além da observação de que alguém só pode ser privado dos direitos fundamentais da liberdade e propriedade por meio de um processo criado por lei (process oriented theory), deve-se consignar que o processo deve ser justo e adequado, ou seja, orientado pelos princípios da justiça, ostentando esta característica até mesmo no momento da criação da norma processual (dimensão material ou substantiva do processo) ${ }^{8}$.

Claro está que se adere neste trabalho ao que se chama de escola da orientação constitucional do processo penal, que supera o mérito do saber prático das formas e trâmites do processo penal para adequar as normas processuais penais aos sistemas de garantias enunciados na Constituição e nos pactos internacionais de direitos humanos. A Constituição de 1988 superou a concepção processual que animou a produção do Código de Processo Penal de 1941 e já não se pode pensar o direito processual penal com "objetivo de maior eficiência e energia da ação repressiva do Estado contra os que delinquem", como propunha Francisco Campos na exposição de motivos do Código ainda vigente $^{9}$. Pelo contrário, adotaremos nesta análise o garantismo penal como modelo

de outro lado é o próprio processo penal que se constitui em instrumento de tutela da liberdade jurídica do réu. (...) A lei do processo é o prolongamento e a efetivação do capítulo constitucional sobre os direitos fundamentais e suas garantias."

${ }^{8}$ De acordo com CANOTILHO, op. cit. p. 494, "o problema nuclear da exigência de um due process não estaria tanto - ou pelo menos não estaria exclusivamente - no procedimento legal mediante o qual alguém é declarado culpado e castigado ("privado da vida, da liberdade e da propriedade") por haver violado a lei, mas sim no facto de a lei poder ela própria transportar a "injustiça” privando uma pessoa de direitos fundamentais. Às autoridades legiferantes deve ser vedado o direito de disporem arbitrariamente da vida, da liberdade e da propriedade das pessoas, isto é, sem razões materialmente fundadas para o fazerem."

${ }^{9}$ Prelecionava o idealizador do Código de Processo Penal de 1941 em suas exposições de motivos: "as nossas vigentes leis de processo penal asseguram aos réus, ainda que colhidos em flagrantes ou confundidos pela evidência das provas, um tão extenso catálogo de garantias e favores, que a repressão se torna, necessariamente, defeituosa e retardatária, decorrendo daí um indireto estímulo à expansão da criminalidade. Urge que seja abolida a injustificável primazia do interesse do indivíduo sobre o da tutela social. Não se pode continuar a contemporizar com pseudo-direitos individuais em prejuízo do bem comum. 
teórico de um processo penal constitucional que enseja um sistema de limites da autoridade punitiva $^{10}$.

Diante do quadro constitucional do processo penal, para a análise da prisão preventiva decretada de ofício, além da cláusula do devido processo legal já citada, partiremos da premissa do direito à liberdade (enunciada no caput do artigo $5^{\circ}$ da Constituição) e da presunção de inocência (produto das conquistas do pensamento liberal no sistema punitivo no século XVIII ${ }^{11}$ já presente na Declaração dos Direitos do Homem e do Cidadão de $1798^{12}$ e disposta no inciso LVII do artigo $5^{\circ}$ da Constituição brasileira de 1988). Por fim, não é possível discutir poderes ex officio do juiz sem se falar no princípio acusatório, "opção inequívoca" ${ }^{13}$ da Constituição Federal de 1988, cujo estudo forma a base desta monografia e sobre o qual nos debruçaremos com mais vagar. Estudar a prisão preventiva de ofício significa estudar como a Constituição vai delinear ou demarcar de maneira exata as condições e o procedimento sob os quais estes direitos fundamentais poderão ser excepcionados: através de um sistema acusatório autêntico.

Neste contexto de recepção das normas pela nova ordem constitucional, o processo penal encontra vários "pontos de choque" entre a antiga tradição da estrutura processual de corte fascista e inquisitória do Estado Novo (que sói encontrar sectários até hoje e que deriva da concepção do delito como infração) com um novo processo penal garantista e acusatório (que deriva da tradição de concepção do delito como conflito). Dentre estes "pontos de choque" temos a prisão preventiva de ofício.

A importância do estudo e delimitação da prisão provisória cautelar, gênero do qual a preventiva é a principal espécie, releva-se pelas preocupações mais

O indivíduo, principalmente quando vem de se mostrar rebelde à disciplina jurídico-penal da vida em sociedade não pode invocar, em face do Estado, outras franquias e imunidades além daquelas que o assegurem contra o exercício do poder público fora da medida reclamada fora do interesse social. Este o critério que presidiu à elaboração do presente projeto de código". Destaca-se do trecho, além da característica marcante autoritária e repressiva que informava a criação do Código, a regressão, o "passo atrás", que a nova lei representava em relação aos diplomas anteriores.

${ }^{10}$ Ver FERRAJOLI, L. Derecho y razón. p. 851 e seguintes.

${ }^{11}$ GOMES Filho, A.M. Presunção de inocência e prisão cautelar. p. 9.

12 Art. 9. Tout homme étant présumé innocent jusqu'à ce qu'il ait été déclaré coupable, s'il est jugé indispensable de l'arrêter, toute rigueur qui ne serait pas nécessaire pour s'assurer de sa personne doit être sévèrement réprimée par la loi.

${ }^{13}$ Supremo Tribunal Federal, ADI 5104 MC, Relator(a): Min. ROBERTO BARROSO, Tribunal Pleno, julgado em 21/05/2014, PROCESSO ELETRÔNICO DJe-213 DIVULG 29-10-2014 PUBLIC 30-10-2014. 
latentes dos estudiosos do processo e dos defensores dos direitos humanos. Em sua feição prática, a prisão preventiva se mostra análoga à pior sorte do réu ao final de todo o processo penal: o encarceramento. Trata-se da medida mais severa a ser tomada durante um processo ${ }^{14}$.

De acordo com os dados oficiais de dezembro de $2012^{15}$, mais de $40 \%$ da população carcerária do Brasil era formada por presos provisórios. O relatório da Comissão Interamericana de Direitos Humanos da OEA, editado em dezembro de 2013, adverte que "uno de los principales desafios que enfrentan la absoluta mayoría de los Estados de la región es el uso excesivo de la detención preventiva, por eso, en razón de la complejidad y trascendencia de esta temática"16.

O poder ex officio do juiz é outro dos assuntos mais debatidos na doutrina processual penal por representar de forma direta o sistema a qual está filiado dado ordenamento. Trata-se de um dos temas centrais na análise da própria identidade da administração da justiça criminal em uma dada jurisdição ${ }^{17}$. A doutrina revela que a tripartição de funções entre os atores processuais e a concentração maior ou menor de tais funções na mão do julgador é de extrema complexidade, pois diz respeito ao poder do Estado-juiz, detentor do poder de punir ${ }^{18}$. "A história do processo pode ser traçada também em termos de quem o domina, ou seja, de quem são seus atores relevantes no seu

\footnotetext{
14 “... l'aplicazione di una misura cautelare significa che lo Stato è intervenuto pesantemente, in maniera repressiva e in funzione di difesa, privando taluno dei suoi beni o addirittura della sua libertà personale.". BERRI, G. Formulario delle misure cautelari personali e reali. p. V. Como observa o processualista estadunidense Joel Samaha, embora haja riscos para a liberdade de um acusado, também é preciso levar em consideração que "[b]eing locked up before trial is a major loss of freedom, but it's more than that. Temporary loss of wages and even permanent loss of a job, separation from family and friends, restrictions on aiding in their own defense, and loss of reputation are also possible consequences for detained defendants. And-all of these take place before defendants are convicted" SAMAHA, J. Criminal Procedure. p. 399/400.

15 Dados extraídos do sítio eletrônico do Ministério da Justiça (http://portal.mj.gov.br/data/Pages/MJD574E9CEITEMID598A21D892E444B5943A0AEE5DB94226PTBR IE.htm) acessados em 15 de outubro de 2014.

${ }^{16}$ p. 5 .

17 "The fundamental difference between the procedural models is the role of the parties and of the judges.". CRYER, R. et alii An introdution to International Criminal Law and Procedure. p. 426. Confiram-se, também as perguntas iniciais das quais parte o jurista croata-americano, Professor da Universidade de Yale, Mirjan Damaška em sua clássica obra de 1986 The faces of justice: "For the process to retain its legal nature, is it necessary that it be controlled, directly or indirectly, by a state 'judge'? What are the essential attributes and functions of this official? Is he primarily a conflict resolver, or an enforcer of state policy, an educator, and a therapeuta?" (loc. 117 of 6774).

${ }^{18}$ GOLDSCHMIDT, J. Problemas jurídicos y políticos del proceso penal.
} 
desenvolvimento" 19 . Como deve ser aplicado o princípio da inércia da jurisdição (ne procedat judex ex officio) e como a atividade do juiz ameaça sua imparcialidade? Esta talvez seja uma das questões mais difíceis a serem enfrentadas pelo processualista, com reflexos para a feição do processo em si, para a atividade probatória e para a aplicação de medidas cautelares.

A natureza do cargo do julgador e seu papel na cena processual levam inevitavelmente ao estudo do processo de substituição do sistema inquisitivo pelo sistema acusatório, tarefa que vem sendo empreendida paulatinamente, com avanços (reformas) e retrocessos (contrarreformas) na maioria dos países da Europa Continental e da América Latina desde a era do Iluminismo. Nos ordenamentos latino-americanos (assim como em Portugal, Espanha e Itália) esse processo de reformas foi intensificado após a redemocratização dos regimes ao final do século XX. Como assumimos, no rastro do pensamento de Bobbio, que os direitos e garantias ${ }^{20}$ fundamentais representam conquistas históricas, importa delinear o processo pelo qual o princípio do acusatório - e não temos dúvida de afirmar que o processo acusatório também representa uma garantia fundamental $^{21}$ - passou a fazer parte dos ordenamentos ocidentais. Este trabalho parte do pressuposto de que a instauração de sistemas acusatórios e a consequente superação dos inquisitórios é um fenômeno do mundo ocidental e que o direito comparado tem muito a

19 LOPES, J.R.L. Uma introdução à história social e política do processo. In WOLKMER, A.C. Fundamentos de História do Direito. p. 352.

${ }^{20}$ Quanto à diferença conceitual entre direito e garantia, adotamos a construída por Rui Barbosa e citada por Scarance FERNANDES, A. Processo penal constitucional, p. 21: "os direitos são disposições meramente declaratórias, imprimindo existência legal aos bens e valores por elas reconhecidos, enquanto as garantias são disposições assecuratórias que têm como finalidade proteger os direitos".

21 Filiamo-nos, conforme ficará claro durante a dissertação, à opinião de que o direito a um processo acusatório configura uma garantia fundamental de nível constitucional no Brasil, assim como defende, para a Espanha, o ex-magistrado do Tribunal Constitucional (1988-1998) Jose Vicente GIMENO Sendra. A Constituição espanhola de 1978, assim como a brasileira de 1988, nem sequer menciona a palavra "acusatório" (tampouco a menciona a Convenção Europeia de Direitos Humanos a que o Reino da Espanha é signatário), diferente da Portuguesa de 1976, que estabelece ipsis litteris: “Art. 32. 5. O processo criminal tem estrutura acusatória, estando a audiência de julgamento e os actos instrutórios que a lei determinar subordinados ao princípio do contraditório". El Derecho Fundamental a un Proceso Acusatorio. In MACIEL, Adhemar Ferreira; SERRANO Gómez, Alfonso; MADLENER, Silma Marlice (coord.). Estudos de Direito Penal, Processual e Criminologia em homenagem ao Prof. Dr. Kurt Madlener. No Brasil, o Supremo Tribunal Federal, como veremos a seguir, fortaleceu a jurisprudência segundo a qual a Constituição de 1988 fez uma "opção inequívoca pelo sistema penal acusatório" em recente julgamento (ADI 5104 MC, Relator(a): Min. ROBERTO BARROSO, Tribunal Pleno, julgado em 21/05/2014, PROCESSO ELETRÔNICO DJe-213 DIVULG 29-10-2014 PUBLIC 30-10-2014). 
aportar neste panorama, assim como o fez para a interpretação de outros institutos como o próprio devido processo legal (due process) e o garantismo.

$\mathrm{Na}$ presente monografia, entenderemos o acusatório como garantia fundamental, princípio ou sistema, conforme a utilização do termo. Trata-se de um conceito profundamente ligado a um processo justo (due process) e a um Estado Democrático de Direito $^{22}$, e que tem como principal enunciado a divisão rígida de atribuições entre os atores do processo ${ }^{23}$.

Neste panorama, o presente trabalho tem como objetivo analisar criticamente $^{24}$ a validade da norma que autoriza o juiz a decretar sponte propria a medida cautelar da prisão preventiva. A “validade” será entendida sob o ponto de vista da lógica jurídica, ou seja, a pertinência da norma ao ordenamento jurídico. A norma inferior é válida porque seu conteúdo material e sua produção não entram em contradição com a norma de hierarquia superior. Daí decorre a necessidade lógica da norma pertencer ao sistema condicionado por um ou alguns princípios fundamentais. É nesse sentido que o acusatório, como foi dito, pode ser entendido como um princípio que condiciona um sistema. Se esse princípio tem assento constitucional, condicionará toda a estrutura normativa inferior. Assim, nosso objetivo é estudar a relação de adequação material da norma que prevê a prisão preventiva de ofício com o princípio acusatório e a relação de pertencimento desta norma ao sistema acusatório. Trata-se de inserir os argumentos e o que

\footnotetext{
22 “O processo assim, em um Estado democrático e, principalmente, em uma sociedade também democrática, revela-se produto da contribuição dialética de muitos e não da ação isolada de um só, ainda que este ummesmo sendo o juiz - atue informado pela disposição de encontrar a solução mais justa, ou, dito com outras palavras, apropriando-se da expressão kelseniana, ainda que este atue para o povo. (...) Deve-se, pois, à concepção ideológica de um processo penal democrático, a assertiva comum de que sua estrutura há de respeitar, sempre, o modelo dialético, reservando ao juiz a função de julgar, mas com a colaboração das partes, despindo-se, contudo, da iniciativa da persecução penal. A estrutura sincrônica dialética do processo penal democrático considera, pois, metaforicamente, o conceito de relação angular ou triangular e nunca de relação linear, sacramentando as linhas mestras do sistema acusatório". PRADO, G. Sistema Acusatório p. 33. PRADO ainda coloca que a adoção do sistema acusatório "toma o lugar das concepções tradicionalistas e religiosas na chamada baixa modernidade”. Op. cit. p. 13.

${ }^{23}$ De acordo com Ferrajoli, "sólo un efectivo pluralismo institucional y una rígida separación de poderes puede garantizar la rehabilitación de la legalidad en la esfera pública según el paradigma del estado de democrático de derecho." Op. cit. prólogo à la edición española. p. 11.

${ }^{24}$ A palavra crítica que aparece no título desta monografia é utilizada em dois sentidos: a) como uma análise sistemática ou uma apreciação minuciosa e criteriosa de um objeto; b) no sentido elaborado pelo filósofo alemão Max Horkheimer e pela Escola de Frankfurt. O trabalho da teoria crítica não se satisfaz com a mera análise objetiva e distante da questão social, mas nela penetra e transforma. HORKHEIMER, M. Critical theory: selected essays. Especialmente o ensaio Traditional and critical theory, p. 188 a 243.
} 
subjaz em cada uma das teses opostas nas grandes dualidades do processo penal moderno: a dualidade entre política criminal e o sistema de garantias ${ }^{25}$ e a dualidade entre reforma e contrarreforma. Esta é, em síntese, a difícil convivência dos dois objetivos do direito processual penal: a realização punitiva do direito penal material (eficácia punitiva) e a garantia dos direitos individuais ${ }^{26}$. O processo histórico que determina a dualidade pode ser entendido como um "movimento pendular", ligada a uma concepção cíclica da história, com sugere o Professor Antonio Scarance Fernandes ${ }^{27}$, ou, à maneira bobbio-kantiana, pode ser entendido como um gradual processo de positivação de direitos fundamentais.

A prisão preventiva de ofício tem origem e implicações na história do ordenamento jurídico brasileiro. $\mathrm{O}$ estudo de tal instituto não pode ocorrer sem uma crítica ao atual procedimento de tomada de decisão da medida cautelar, extremamente vinculado ao sistema inquisitório (i.e. centrado no julgador, autoritário, anti-garantista, burocrático e escritural). Como será visto, a divergência aqui analisada não se esgota simplesmente em uma questão técnico-jurídica, mas perpassa questões ideológicas e históricas que serão mencionadas no decorrer do trabalho.

Por fim, ao lado do objetivo primário de estabelecer a (in)validade da disposição da prisão preventiva de ofício, um objetivo lateral da monografia, para “orientar nuevas prácticas" e para "desplazar a los saberes anteriores", seria indicar uma ideia geral de como a ordem infraconstitucional poderia dispor acerca da forma da tomada de decisão da prisão preventiva, de tal maneira que os resquícios inquisitórios sejam neutralizados, substituindo-se o procedimento atual por um mais consentâneo com o princípio e o sistema acusatórios. Seria apenas uma continuação das "modificações transformativas" ${ }^{28}$ de reforma do processo penal brasileiro na mesma linha da implantação do cross-examination em 2008.

Para alcançar estes objetivos, a dissertação será dividida em cinco capítulos principais. O primeiro capítulo tratará da formação, distinção e definição dos

\footnotetext{
${ }^{25}$ BINDER, A. M. Derecho procesal penal. p. 21.

${ }^{26} \mathrm{Da}$ forma enunciada por GRINOVER, A.P. op. cit. p. 22: "é preciso manter a ordem, mas isso deve ocorrer com o máximo respeito pela Justiça”.p. 9. É de se consignar também a pureza teórica de Goldschmidt para que o fim do processo penal é o alcance de uma decisão de mérito transitada em julgado.

${ }^{27}$ FERNANDES, A. S. Teoria geral do procedimento. p. 61.

${ }^{28}$ Expressão utilizada por DAMAS̆KA, M. Aspectos globales de la reforma del proceso penal. Reformas a la Justicia Penal en las Americas. p. 38.
} 
sistemas processuais penais: o inquisitivo, o acusatório e o misto. Como a definição exata de cada tipo de sistema escapa da proposta do trabalho, será dada prevalência para os aspectos relevantes para a questão em tela: o papel do juiz, o papel que a prisão cautelar representa em cada sistema, e a burocratização/oralização dos procedimentos. O segundo capítulo será dedicado ao sistema processual penal brasileiro, seu delineamento histórico e as normas constitucionais, supralegais e infraconstitucionais que o determinam. É neste capítulo que será derivado o princípio que determina um sistema constitucional acusatório no Brasil e os novos diplomas que adaptam o sistema brasileiro ao aludido princípio. Também aqui serão expostas as normas que determinam o decreto da prisão preventiva. A partir das definições dadas nos dois primeiros capítulos, o terceiro capítulo trará um rol de argumentos favoráveis e contrários à validade da prisão preventiva de ofício, expostos criticamente, depurando-se os conceitos gerais dados anteriormente. O quarto capítulo trará informações acerca da prisão preventiva de ofício recolhidas do direito comparado, mais especificamente dos ordenamentos espanhol, português, italiano, mexicano e chileno. Oportunamente se justificará a escolha de cada um destes países. A conclusão virá no último capítulo, com objetivo de fazer um balanço dos argumentos e expor a forma da tomada de decisão pode ser adaptada ao modelo constitucional brasileiro de 1988.

Duas observações restam para um melhor entendimento da monografia. Toma-se o cuidado de separar o "ativismo judicial" no campo processual penal, daquele em voga no campo do processo constitucional e civi,l em que se busca a judicialização das políticas públicas. O ativismo do juiz nos dois casos guarda diferenças. Quando se busca a efetivação de direitos sociais (de terceira geração), o sopesamento de bens constitucionais repousa na separação dos poderes. No caso do ativismo judicial no processo penal, trata-se de uma ponderação entre a efetividade da jurisdição e os direitos individuais (de primeira geração). No primeiro caso, não há dúvida que o juiz não age de ofício e, sim provocado pela parte, como é a regra no processo civil ${ }^{29}$. O caso que circunscrevemos nesse trabalho trata essencialmente da ponderação do direito fundamental à liberdade e a garantia do devido processo legal, de um lado, e o direito punitivo do Estado-juiz, de outro.

\footnotetext{
${ }^{29}$ Art. 797 do Código de Processo Civil.
} 
A última observação diz respeito à falaciosa expressão do "ativismo próréu do juiz". No processo penal vige o princípio do in dubio pro reo, i.e. é o Estado, através de seu órgão acusador, que deve cumprir um standard probatório de tal forma que licitamente se possa vulnerar o direito individual de liberdade tanto para a pena definitiva quanto para as medidas cautelares pessoais ${ }^{30}$. Quando o julgador imparcial revoga uma medida cautelar pessoal de ofício, em realidade está-se a dizer que o órgão acusador não logrou atingir o standard necessário para se quebrar o default da liberdade do indivíduo. Como o que se discute é o direito fundamental de liberdade e como a lei determina suas exceções, não se cogita o contrário, ou seja, não se discute se o juiz pode extinguir uma medida cautelar de ofício e, por este motivo, falar em ativismo judicial pró-réu constitui uma falácia. Usando as palavras da Corte Europeia de Direitos Humanos, "a presunção é em favor da liberdade" ${ }^{31}$. No mais, de acordo com a Constituição Federal de 1988, a prisão ilegal será imediatamente relaxada pela autoridade judiciária (art. $5^{\circ}$, inciso LXV). Desta forma, como mostra o caso espanhol ${ }^{32}$, por exemplo, não há uma incongruência lógica alguma em tolher o poder punitivo ou cautelar de ofício do juiz e ampliar sua atividade na defesa dos direitos fundamentais individuais.

\footnotetext{
${ }^{30}$ Quanto às medidas cautelares reais, o raciocínio é o mesmo, tendo o direito de propriedade como parâmetro.

31 "The presumption is in favour of release." Caso Margaretić vs. Croácia. Julgado em 13 de outubro de 2014. Disponível em http://hudoc.echr.coe.int/sites/eng/pages/search.aspx?i=001-144367.

${ }^{32} \mathrm{Na}$ Espanha, por exemplo, em que a reforma veio limitar o poder de ofício do juiz e o requerimento da parte é um pressuposto da prisão cautelar, o juiz pode decidir pela liberdade provisória sem fiança do réu sem audiência das partes. O item final do art. 528 da Lei de Enjuiciamento prevê que "todas las Autoridades que intervengan en un proceso estarán obligadas a dilatar lo menos posible la detención y la prisión provisional de los inculpados o procesados." O art. 539, \$4 dispõe que "siempre que el Juez o Tribunal entienda que procede la libertad o la modificación de la libertad provisional en términos más favorables al sometido a la medida, podrá acordarla, en cualquier momento, de oficio y sin someterse a la petición de parte."
} 


\section{SISTEMAS PROCESSUAIS PENAIS}

Os argumentos contrários e favoráveis ao instituto da prisão preventiva de ofício giram em torno do eixo do sistema processual penal, de maneira que sem o estudo dos modelos processuais que vicejaram nos Estados do ocidente, no intelecto dos processualistas, e particularmente no Brasil, não é possível especular sobre a validade da norma objeto deste trabalho.

De plano, fixaremos os conceitos de duas categorias do direito: princípio e sistema. Utiliza-se aqui o conceito de princípio desenvolvido por Alexy, para quem "princípios são normas que ordenam que algo seja realizado na maior medida possível dentro das possibilidades jurídicas e fáticas existentes. Princípios são, por conseguinte, mandamentos de otimização, que são caracterizados por poderem ser satisfeitos em graus variados e pelo fato de que a medida devida de sua satisfação não depende somente das possibilidades fáticas, mas também das possibilidades jurídicas" ${ }^{, 33}$. Seguindo o conceito do Professor alemão, podemos extrair das normas constitucionais e supralegais um mandamento de otimização de um processo penal que seja o mais acusatório possível, conforme se verá no capítulo seguinte. Entenderemos o acusatório como um princípio implícito na Constituição Federal de 1988, decorrente de várias de suas disposições ${ }^{34}$.

Vem da filosofia a definição de sistema. Kant entendia sistema como a unidade de múltiplas cognições sob uma única ideia, ou seja, uma unidade finalística à qual todas as partes são ligadas e pela qual são relacionadas entre $\mathrm{si}^{35}$. Em outra passagem, Kant define sistema como "um conjunto de conhecimentos ordenados de acordo com um princípio" ${ }^{36}$. Mais precisamente no campo do direito, Canaris define o sistema jurídico como "uma ordem teleológica de princípios gerais de direito"37, apresentando dois conceitos fundamentais que o compõem: a ordenação e a unidade ${ }^{38}$. Especificamente

\footnotetext{
${ }^{33}$ ALEXY, R. Teoria dos Direitos Fundamentais. p. 90.

${ }^{34}$ É de se consignar que Jacinto Nelson de Miranda COUTINHO, O papel do novo juiz no processo penal. Crítica à Teoria Geral do Direito Processual Penal. p. 17, entende que o princípio dispositivo é o que condiciona o sistema acusatório enquanto o princípio inquisitivo dá sustentação ao sistema inquisitório. A posição defendida no texto foi extraída de PRADO, G. op. cit. p. 60, para quem o sistema acusatório seria mais amplo, sendo condicionado por outros princípios como a publicidade e a oralidade, por exemplo.

${ }^{35}$ KANT, I. Critique of Pure Reason. p. 691. "I understand by a system, however, the unity of the manifold cognitions under one idea."

${ }^{36}$ KANT, I. Metaphysical foundations of natural science. Theoretical philosophy after 1781. p. 183.

${ }^{37}$ CANARIS, C.W. Pensamento sistemático e conceito de sistema na Ciência do Direito. p. 103.

${ }^{38}$ Op. cit. p. 12.
} 
quanto à unidade, Canaris a trata como um fator que impede que a multiplicidade se disperse "numa multitude de singularidades desconexas, antes devendo deixá-las reconduzir-se a uns quantos princípios fundamentais" ${ }^{, 39}$.

Das definições, sobressai a característica mais relevante do sistema normativo para o presente trabalho: a coerência interna. Conforme menciona Geraldo $\operatorname{Prado}^{40}$, é de se notar não só a coerência interna dos componentes do sistema (no caso dos sistemas jurídicos, as normas jurídicas), mas a compatibilidade de um sistema restrito, ou subsistema, com outro mais abrangente. $\mathrm{O}$ autor exemplifica que o sistema processual penal está contido no sistema judiciário, que por sua vez está contido no sistema constitucional. Não é destoante, assim, o fato de Bobbio utilizar a palavra sistema como sinônimo do próprio ordenamento jurídico como um todo. Para Bobbio, sistema é "uma totalidade ordenada, um conjunto de entes entre os quais existe uma certa ordem"41.

De acordo com Alexy, um sistema jurídico é tão mais coerente quanto melhor fundamentadas são suas determinações ${ }^{42}$. "Quanto melhor é a estrutura da fundamentação de uma classe de declarações, tanto mais coerente é essa classe de declarações". "Uma exigência mínima de coerência é que entre as declarações de um sistema, no fundo, existam relações de fundamentação. Uma classe de declarações, entre as quais não existe nenhuma relação de fundamentação, pode, sem dúvida, ser consistente, mas ela não é coerente em nenhum sentido. Ela é tanto mais coerente quanto mais relações de fundamentação existirem". Alexy segue propondo vários critérios de coerência, estabelecendo que o sistema é tanto mais coerente: a) quanto mais extensas as correntes de fundamentação; b) quanto mais correntes de fundamentação têm uma premissa de partida comum; c) quanto mais correntes de fundamentação têm uma conclusão comum; d) quanto mais relações de primazia são determinadas entre os princípios; e) quanto mais fundamentações empíricas e analíticas mútuas um sistema contém. Para os objetivos deste trabalho, seria conveniente, nesta linha, analisar quais seriam os fundamentos da norma que prevê prisão preventiva de ofício.

\footnotetext{
${ }^{39}$ Op. cit. p. 13.

${ }^{40}$ Op. cit. p. 55.

${ }^{41}$ BOBBIO, N. Teoria do ordenamento jurídico. p. 71.

${ }^{42}$ ALEXY, R. Constitucionalismo discursivo. p. 117 e seguintes.
} 
Para Kelsen, a unidade da pluralidade de normas é o fundamento de validade de todas estas normas: a norma fundamental ${ }^{43}$. Uma norma que não tem relação de unidade com o todo do sistema não faz parte dele, e pode-se dizer, está em oposição a ele. A coerência interna é dada na forma da hierarquia que as normas inferiores guardam com as superiores. Ao quebrar a unidade, a norma contraria o princípio ao mesmo tempo em que desnatura o sistema. Se contraria o princípio e faz desativar todo o sistema, a norma é inválida (inconstitucional, ou até mesmo ilegal, quando contrariar o sistema supralegal de normas oriundas de pactos internacionais sobre direitos humanos).

É desta forma que o sistema processual guarda sua relação com o sistema constitucional. "Uma lei que proponha a iniciativa do juiz para o processo penal de cunho condenatório não pode pertencer ao sistema processual acusatório embasado em uma Constituição que o consagre e, portanto, tal lei não será válida, ainda que funcional no sentido utilitarista, de mera adjudicação de uma solução ao conflito de interesses penal"44. Além disso, "um sistema acusatório que não funciona devido a sua ineficiência ou devido a falta de coerência, não é acusatório" 45 .

Com este instrumental teórico se pretende responder à pergunta: a norma que prevê a prisão preventiva de ofício contraria, ou seja, é incoerente com o sistema processual penal brasileiro?

Neste ponto do estudo da adequação às normas e da coerência do sistema processual penal, surge a questão da "pureza dos sistemas", que deve ser enfrentada desde logo. Não raro, o argumento segundo o qual uma norma está em desacordo com o sistema é rechaçado com a ideia de que não existem "sistemas puros" 46 . De fato, é possível entender os sistemas processuais penais como "tipos ideais", construções puramente racionais, hipotéticas e abstratas, cujo conceito foi desenvolvido na sociologia por Max Weber $^{47}$. Os sistemas processuais penais reais, em vigor nos diferentes Estados, representariam apenas aproximações dos “tipos ideais" e poderiam ser observados ora

\footnotetext{
${ }^{43}$ KELSEN, H. Teoria pura do direito. p. 228.

${ }^{44}$ PRADO, G. op. cit. p. 56.

${ }^{45}$ PANZAVOLTA, M. Reforms and counter-reforms in the Italian struggle for an accusatorial criminal law system. p. 623, tradução livre.

${ }^{46}$ SAAD, M.; MALAN, D. R. Origens históricas dos sistemas acusatório e inquisitivo. p. 413.

${ }^{47}$ WEBER, M. Economy and society. p. 6.
} 
aspectos inquisitórios, ora aspectos acusatórios, dependendo da norma estudada ${ }^{48}$. Perderia sentido, desta forma, a pergunta deduzida acima. Se todos os sistemas vigentes representam uma mistura de preceitos dos tipos ideais, de nada importa se uma norma específica tem perfil inquisitório ou acusatório. No entanto, como foi visto, a coerência do sistema advém da relação de fundamentação que suas normas específicas guardam com os preceitos superiores (Alexy). Dito de outra forma, a incoerência do sistema equivale a uma inconstitucionalidade ou a uma ilegalidade (quando se trata das normas supralegais).

Pode-se entender, também, que não há um sistema puro, mas há características típicas de cada sistema. Damaška elabora a interessante comparação da classificação dos sistemas com a interpretação das escolas de arte. Muitas das vezes é difícil determinar a que escola artística a obra pertence, mas, sim, é possível isolar e identificar as características específicas de determinadas escolas ${ }^{49}$, de maneira que uma pintura fovista de Matisse nunca poderia ser confundida com uma gravura cubista de Picasso, embora os dois mestres tenham sido contemporâneos ${ }^{50}$. Para classificar o sistema de um determinado ordenamento processual penal, o estudioso do direito compara as disposições legais reais com as características consideradas essenciais de cada um dos $\operatorname{modelos}^{51}$.

Assim, da mesma forma que se pode dizer que não há um sistema acusatório puro no mundo empírico, também não há (e talvez nunca tenha havido) um sistema inquisitório puro, em que todas as funções do processo sejam colocadas numa só pessoa de forma absoluta ${ }^{52}$.

Outro prisma através do qual se pode ver a classificação dos sistemas processuais penais é a sua relação com a concepção filosófica de Estado, de extrema

\footnotetext{
${ }^{48}$ De acordo com ILLUMINATI, G. The accusatorial process from the Italian point of view, p. 297-298, as noções de processo acusatório e inquisitivo são abstrações, modelos hipotéticos que resultam da generalização de ordenamentos e "seu conceito depende da escolha de valores ideologicamente orientada" (tradução livre). Segundo ARMENTA Deu, T. Sistemas procesales penales, p. 11, “...ningún sistema reúne las esencias de una concepción ortodoxa y que todos son objeto de frecuentes y fundadas diatribas, incluso en torno a una misma institución como es el caso de las soluciones negociadas.(...) no existen modelos que salvaguarden la ortodoxia de ningún sistema, ni ninguno de los vigentes satisfaría hoy en día por completo las exigencias del 'proceso debido'.

${ }^{49}$ DAMAŠKA, M. The faces... loc. 5355 of 6774 footnote 6.

${ }^{50} \mathrm{O}$ exemplo é nosso, sobre a ideia de Damaška.

${ }^{51}$ ILLUMINATI, G. op. cit. 298.

${ }^{52}$ Os tribunais eclesiásticos, por exemplo, quando a pena era de sangue, passavam sua execução para o poder secular.
} 
relevância para o estudo da posição cênica do juiz no processo. Neste sentido, o processo penal empresta conceitos e definições da ciência política. De acordo com Goldschmidt, “los principios de la política procesal de una nación no son otra cosa que segmentos de su política estatal en general. Se puede decir que la estructura del proceso penal de una nación no es sino el termómetro de los elementos corporativos o autoritarios de su Constitución. Partiendo de esta experiencia, la ciencia procesal ha desarrollado un número de principios opuestos constitutivos del proceso. La mutua lucha de los mismos, el triunfo ya del uno, ya del otro, o su función, caracterizan la historia del proceso"53.

Para além de uma visão segundo a qual o Estado autoritário demandaria um processo mais inquisitório, enquanto o processo acusatório seria mais adequado a um Estado liberal ("inquest-contest” dichotomy), Damaška - sob influência de Max Weber e os graus de burocratização que influenciam a forma de administração da justiça - propõe uma classificação mais complexa, um "excurso" da visão tradicional. Trabalhando com a ideia de diferentes organizações estatais do sistema de justiça, a autoridade estatal e a influência das mudanças do papel do governo a obra de Damaška separa o Estado-juiz reativo, focado na resolução de conflitos (conflict-solving), do Estado-juiz intervencionista na ordem processual, que impõe certa política de segurança (police implementing). Paralelamente, separa o sistema de justiça colaborativa, de relações horizontais, com o sistema de justiça hierárquico, de relações verticais. Deste modo, embora o sistema inquisitório esteja mais relacionado com um Estado intervencionista de tipo hierárquico, enquanto o acusatório com o Estado reativo e colaborativo, é possível combinar as características de diferentes formas, como um Estado reativo com uma justiça hierárquica; ou um Estado intervencionista com uma justiça colaborativa. Assim, nem o sistema angloamericano teria monopólio do sistema de resolução de conflito, nem os sistemas continentais teriam monopólio da implementação de política $^{54}$.

Entretanto, uma vez que regimes políticos se legitimam a partir da administração da justiça ${ }^{55}$, segue possível e útil a simplificação que o próprio Damaška

\footnotetext{
${ }^{53}$ GOLDSCHMIDT, J. op. Cit. 67.

${ }^{54}$ DAMAŠKA, M. The faces of justice... loc. 351 of 6774

55 "In the criminal process, it was similarly argued that ideological shifts affect the degree of protection accorded the defendant from the state: the comparatively peculiar position of the accused in the AngloAmerican criminal prosecution has time and again been linked to tenets of classical liberalism" DAMAŠKA, M. The faces of justice... loc. 269 of 6774.
} 
consigna, de que o sistema acusatório seria a realização das virtudes de uma administração liberal, enquanto, por contraste, o sistema processual continental pré-revolução francesa serviria a um Estado autoritário.

Paralelamente às formulações de Damaška, colocamos as de Alberto Binder e Michel Foucault, que identificam duas tradições nos sistemas punitivos ao longo da história e que serão de grande utilidade no presente estudo. A uma tradição do delito como conflito, oriunda dos procedimentos ateniense e romano republicano, opõe-se à tradição do delito como infração, típica da Roma imperial, da administração da justiça clerical e da formação dos estados nacionais.

Em suma, a posição mais ou menos ativa do juiz está diretamente ligada a um sistema processual penal que, por sua vez, responde a certa concepção de administração da justiça por parte do Estado. O primeiro grande exemplo da relação entre a estrutura do Estado e a conformação do sistema de justiça é a passagem da República para o Império na Roma antiga. Trata-se, como diz Julio Maier, de "un ejemplo valiosísimo acerca de las transformaciones que sufre el enjuiciamiento penal a impulsos de la ideología política imperante" ${ }^{, 56}$. Quando os cônsules foram substituídos por um magistratus extraordinarius, o ditador perpétuo Júlio César (44 AC), a tônica passou a ser a concentração de poder. As características do processo penal da República - aclamada pelos pensadores do século das luzes como uma barricada das liberdades individuais dos cidadãos $^{57}$ - deu paulatinamente lugar à cognitio extraordinaria estruturada sobretudo para "proteger o poder imperial absoluto" $" 58$. Esta nova forma centralizada de processo penal foi ganhando terreno primeiro nos crimes mais relevantes contra o Imperador e, mais tarde, estendeu-se para os demais delitos. O poder ex officio (termo latino que significa 'em virtude do ofício ou posição', “em outras palavras, como um magistrado estatal, a estes oficiais era permitido iniciar procedimentos criminais contra cidadãos como parte de suas obrigações ${ }^{\prime 59}$ ) ganhava força no ambiente autoritário e se tornava a regra. O processo se tornava secreto e escrito. A tortura, abandonada durante o regime republicano, retornava como meio de extrair a prova do acusado. A prisão processual era necessária para que tais instrumentos funcionassem melhor. Outro exemplo da imbricação processo/Estado é o

\footnotetext{
${ }^{56}$ MAIER, J.B.J. Derecho Procesal Penal. Tomo I. p. 272.

${ }^{57}$ ILLUMINATI, G. The accusatorial process from the Italian point of view. p. 300.

${ }^{58}$ ILLUMINATI. G. op. cit. p. 300.

${ }^{59}$ ILLUMINATI. G. op. cit. p. 300.
} 
recrudescimento dos direitos individuais verificado nas legislações nazista e fascista, com reflexos na elaboração do Código de Processo Penal ainda em vigor no Brasil, como demonstra sua exposição de motivos.

Há, entretanto, vários contraexemplos desta relação. Temos no Brasil a inserção da defesa no inquérito policial em plena vigência da carta de inspiração fascista de $1937^{60}$. Outrossim, é sensível o abrandamento de alguns aspectos do processo penal brasileiro em um dos períodos mais autoritários da história do país (1964-1985) em contraste com o movimento de limitação das liberdades públicas nas primeiras duas décadas de vigência da Constituição de 1988. Contudo, algumas observações devem ser feitas. A primeira diz respeito ao descompasso entre a lei e a prática "dos porões" da ditadura, onde os institutos mais básicos da inquisição eram utilizados (unificação da figura do acusador e do juiz, tortura, prisão processual automática etc. ${ }^{61}$. Paula Bajer, por exemplo, propõe três aspectos de análise do processo penal entre 1964 e 1985: “a) ações ilícitas cometidas por agentes investidos de autoridade pública (torturas, prisões, ilegais, desaparecimentos e mortes de pessoas consideradas "subversivas"); b) legalidade (atos institucionais e leis processuais do período, inclusive para crimes comuns); c) processualização das condutas criminosas, políticas ou não."62. No mais, o suposto movimento "progressista" da época ditatorial também pode ser entendido como casuísmo legislativo, como, por exemplo, a Lei 5.941/73, apelidada de "Lei Fleury" em razão de ter sido elaborada "sob medida" para que o delegado Sergio Paranhos Fleury aguardasse o julgamento de um crime doloso contra a vida em liberdade ${ }^{63}$. Estas leis devem ser entendidas como progresso processual penal apenas no sentido figurativo da expressão, já que não passavam de letra morta, quando não eram utilizadas para salvaguardar certa elite. É inadmissível que se fale em "progresso" do processo penal quando as liberdades civis estavam suspensas, ministros do Supremo Tribunal Federal eram afastados ao talante dos

\footnotetext{
${ }^{60}$ ALMEIDA, J.C.M. Princípios fundamentais do Processo Penal p. XXII.

${ }^{61}$ PROJETO "BRASIL: NUNCA MAIS". O regime militar.

${ }^{62}$ BAJER, Paula. Processo Penal e cidadania. p. 37.

63 “Começara-se transferindo aos tribunais militares o julgamentodos crimes contra a segurança do Estado, mas isso pareceu pouco. Suspendeu-se o habeas corpus, e transformou-se a tortura em politicade Estado, mas isso não era tudo. Protegendo-se das anomalias que provocara, a ditadura acobertara ladroagens de seus agentes, mas isso também não bastara. Tornara-se necessário reformar a lei penal para assegurar a liberdade de um condenado." GASPARI, E. A ditadura escancarada. p. 384.
} 
militares ${ }^{64}$, e as prisões arbitrárias, a tortura e a execução sumária de inimigos do regime eram toleradas pelo Judiciário.

No mais, embora de fato tenhamos uma estrutura contitucional de Estado democrático de direito após 1988, "não houve uma ruptura com o passado autoritário",65, ou, ao menos, não houve uma ruptura completa, guardando nosso sistema de justiça criminal forte componente inquisitivo ${ }^{66}$.

Diante do quadro, fica difícil que tais contraexemplos suplantem a afirmação de que a concepção filosófica de Estado e processo penal estão extremamente ligadas e que "a estrutura do processo penal contém diferentes noções de Estado - como ele funciona na administração da justiça; como ele se relaciona com a autonomia do indivíduo; e como ele limita tal autonomia"67. Estabelecer este ponto é de extrema importância para o presente trabalho, já que um juiz que decreta uma prisão preventiva sponte propria traz consigo uma concepção jurídica muito específica do sistema processual penal no qual está inserido e do aparato estatal repressivo.

Note-se que não se trata de maior ou menor monopólio estatal na persecução penal, já que mesmo nas jurisdições adversariais do common law, a acusação é exercida quase exclusivamente por um órgão estatal. A diferença é que nos regimes mais marcadamente autoritários os poderes de controle social e antecipação da pena passam da mão do acusador (que ainda detém a iniciativa da medida) para a mão do julgador (que, além da iniciativa, detém o poder do julgamento).

Tendo em conta as observações sobre a pretensa "pureza" dos sistemas e sua relação estreita com a concepção de Estado, resta dizer que o isolamento teórico dos dois grandes modelos de processo penal é tarefa complexa e pode parecer, em alguns

\footnotetext{
${ }^{64}$ Caso dos Ministros Evandro Lins e Silva, Victor Nunes Leal e Hermes Lima, todos aposentados compulsoriamente pelo Ato Institucional $\mathrm{n}^{\mathrm{o}}$ 5, de 13 de dezembro de 1968.

${ }^{65}$ PRADO, G. op. cit. p. 37. Neste mesmo sentido, CRUZ, R.S.M.C. Com a palavra, as partes: "nosso sistema processual penal, em que pese caracterizado como acusatório (com separação das funções de acusar, defender e julgar), nunca conseguiu livrar-se do ranço inquisitorial que vem de longa data."

${ }^{66}$ A persistência de características inquisitórias é comum nos sistemas de justiça europeus continentais e seus derivados, como o Brasil. Diz Ferrajoli que "[s]i el modelo garantista de legalidad penal y procesal que hasta ahora se ha descrito sumariamente no se remonta más allá de dos siglos atrás, sus lecciones y refutaciones tal y como si manifiestan en las divergencias entre principios y praxis mencionadas en la introducción, enlazan con una tradición autoritaria mucho más antigua y nunca realmente interrumpida." (FERRAJOLI, L. Derecho y razón. p. 40/41.)

${ }^{67}$ ILLUMINATI, G. op. cit. p. 299.
} 
momentos, imprecisa ou subjetiva, o que levou alguns doutrinadores a concluírem que o estudo das diferenciações entre os sistemas processuais penais já estivesse superado ${ }^{68}$. Como exemplo de tal imprecisão, pode-se citar a divergência na forma de se estudar o processo entre a doutrina anglo-americana e europeia continental. Enquanto nesta, a grande dicotomia dos sistemas é formada pelo binômio inquisitório/acusatório, naquela, as diferenças na administração da justiça são vistas essencialmente por contraste entre sistemas adversariais e sistemas não adversariais ou inquisitórios. A diferenciação segue, porém, em voga no pensamento do processo penal atual, principalmente devido ao processo de reformas da justiça penal por que passa grande parte dos países adeptos do sistema europeu continental e que tem em sua essência uma superação da antiga tradição inquisitória ${ }^{69}$. De acordo com Gimeno Sendra, "el binomio acusatorio-inquisitivo tiene la virtualidad de indicarnos mediante qué distribuición de roles y bajo qué condiciones se realizará el enjuiciamiento del objeto procesal penal ${ }^{, 70}$.

A diferenciação dos sistemas remonta ao século XII, quando se separavam os processos que necessitavam de uma parte para se desenvolverem ("processus per accusationem") e aqueles que podiam ser iniciados sem um litigante privado ("processus per inquisitionem"). Os conceitos se desenvolveram até que o Iluminismo concebeu dois modelos: um que prevalecia na prática (inquisitorial) e outro teoricamente superior e preferível (acusatório) ${ }^{71}$. Temos, então, a diferença fundamental entre os modelos: o papel das partes e, principalmente, do juiz no processo ${ }^{72}$.

A partir destas observações, trataremos em separado dos sistemas inquisitório, acusatório e misto. Uma vez que o estudo pormenorizado de cada modelo se reveste de inúmeros aspectos jurídicos, culturais, políticos e sociais que fogem ao escopo específico deste trabalho, pretende-se realizar apenas um recorte de três aspectos principais que servirão como instrumento de análise do tema específico da prisão preventiva de

\footnotetext{
${ }^{68}$ ALMEIDA, J.C.M. op. cit. p. XIX e seguintes. Neste sentido, ILLUMINATI, G. The accusatorial... p. 298 em tradução livre: "A distinção entre os sistemas acusatório e inquisitivo contém estruturas analíticas dogmático-teóricas e históricas, que, apesar de não serem mutuamente excludentes, nem sempre coincidem". ${ }^{69}$ Sobre o assunto, cita-se a obra de Alberto BINDER, Derecho Procesal Penal, de 2013, principalmente o capítulo com o sugestivo título "Contra la inquisición: historia y tradiciones en la configuración de la justicia penal'.

${ }^{70}$ p. 266.

${ }^{71}$ DAMAS̆KA, M. The faces of justice... loc. 162 of 6774

72 "The fundamental difference between the procedural models is the role of the parties and of the judges". CRYER, R. et. alii. An introdution to International Criminal Law and Procedure.p. 426.
} 
ofício. Faremos, então, um delineamento do processo histórico de formação de cada modelo, fixando o papel do juiz e da prisão preventiva em cada um dos modelos. Estas três dimensões dos sistemas darão subsídios para que se entendam melhor as origens, os motivos e as implicações da norma que prevê a possibilidade de prisão preventiva de ofício.

É de se observar que bastariam os aspectos do papel do juiz e da prisão preventiva em cada modelo. No entanto, voltando à primeira frase da introdução deste trabalho, entendemos a aquisição de direitos (nos quais incluímos a instituição de um processo autenticamente acusatório) como um gradual efeito de um processo histórico. Como diz Binder, "la justicia penal, como todo campo social, ha sido configurada históricamente. Por ello se encuentra atravesada por relatos históricos y tradiciones. Dado que todo campo social ha sido gestado a lo largo de los años, su estructura actual (estado del campo) es el resultado de una génesis, que es necesario esclarecer" ${ }^{73}$. De acordo com Illuminati ${ }^{74}$, sob uma perspectiva histórica, é relevante saber qual é a parte a quem é dado o poder de persecução, e é relevante saber se o juiz pode dar início a procedimentos "motu proprio",75. A raiz histórica dos sistemas vigentes também é uma forma usual de se diferenciar os grandes tipos ideais: um herdeiro das práticas inglesas (sistema do common law anglo-americano), e outro desenvolvido a partir das práticas da Europa continental (civil law). Apesar do critério da filiação histórica tampouco ser perfeito - já que temos casos como o Chile, que adotou, após a reforma, um sistema muito semelhante ao adversarial - auxilia a entender a configuração histórica dos sistemas atuais.

\subsection{Modelo acusatório}

\subsubsection{Delineamento histórico}

O direito grego e o romano pré-imperial pautavam-se pelo sistema acusatório popular, que consistia na "facultad de cualquer ciudadano de perseguir

\footnotetext{
${ }^{73}$ BINDER, A.M. op. cit. 255.

${ }^{74}$ Op. cit. p. 298-299.

75 Illuminati explica que a expressão latina significa "por seu próprio impulso" e era comumente utilizada para descrever um edito iniciado pelo papa sem consulta. 
penalmente al infrator". Fundava-se na soberania cidadã ateniense, ou seja, na participação direta dos cidadãos para acusar e julgar. A exceção seria formada pelos delitos privados, que só permitiam a persecução pelo ofendido ou seus substitutos. De acordo com Julio Maier, “como en todos los pueblos antiguos, el juicio era oral, público y contradictorio" $" 76$.

O direito processual penal ateniense, segundo Maier ${ }^{77}$, tinha as características marcantes da soberania popular, que concentrava a acusação e o julgamento. Havia certa paridade de armas entre acusação e defesa, que debatiam em um contraditório público em frente a um Tribunal popular. A tortura e os juízos de deus eram admitidos, e as decisões eram irrecorríveis.

Conforme ensina Illuminati, na fase da República Romana a natureza privada da persecução penal fez emergir as características que mais tarde constituiríam a base do sistema acusatório, como o poder discricionário para dar início a uma persecução penal, o ônus da prova nas mãos da acusação, a paridade de armas entre as partes e seu controle da prova, o princípio da publicidade e oralidade do julgamento e, mais relevante para o presente trabalho, o papel passivo do juiz como um árbitro da disputa ${ }^{78}$. A regra durante os primeiros tempos da República era a liberdade do acusado durante o processo, desde que apresentasse fiadores idôneos ${ }^{79}$.

Em um movimento de concentração e passagem do poder do senado ao imperador (como será visto no capítulo sobre o sistema inquisitório), as formas populares

\footnotetext{
${ }^{76}$ MAIER, J.B.J. op. cit. p. 269. "I. Tribunal popular. II. Acusación popular, por la facultad acordada a cualquier ciudadano para presentar querella contra la persona a quien creía autor de un delito público o partícipe en él. III. Igualdad entre acusador y acusado, quien, de ordinario, permanecía en libertad durante su juzgamiento. IV. Publicidad y oralidad del juicio, que se resumía en un debate contradictorio entre acusador y acusado, frente al tribunal y en presencia del pueblo. V. Admisión de la tortura y los juicios de Dios como medios de realización probatoria. VI. Valoración de la prueba según la intima convicción de cada uno de los jueces, quienes votaban a favor o en contra depositando un objeto que daba a conocer el sentido del sufragio. VII. Decisión popular inimpugnable."

${ }^{77}$ Idem. Ibidem p. 272.

${ }^{78}$ Cf. ILLUMINATI, G. op. cit. p. 300: In this phase, features that would later be considered typical of the accusatorial system emerged and were associated with the private nature of the prosecution, including the discretionary power to start a prosecution; the burden of proof on the prosecutor; the equality of arms between the parties and their control of the evidence; the principle of publicity and orality of the trial; and, finally, the judge's passive role as the arbitrator of the dispute. The private accuser was left in charge of gathering the evidence. The Praetor could authorize him to use coercive powers in his investigations. European reformist lawyers, beginning in the 18th century, viewed the criminal process of the Republican time of Rome as a bulwark of the citizen's individual liberties and began to consider the accusatorial system a typical expression of a democratic regime.

${ }^{79}$ ALMEIDA J. J.M. op. cit. p. 319.
} 
de julgamento marcadas pela resolução do conflito gerado pelo delito foram abrindo caminho para uma forma de administração da justiça mais autoritária, de implementação da política imperial.

Com o colapso do Império Romano do Ocidente e a pulverização do poder no feudalismo, o procedimento acusatório voltou a ganhar força embasado no direito germânico antigo, mas com uma visão de combate físico (duelos) e místico (judicium Dei). O objetivo do processo era prevenir a guerra generalizada dos clãs. À medida que a burocracia continental foi se desenvolvendo, o sistema adversarial foi se transformando em uma disputa perante o tribunal ${ }^{80}$.

As partes tinham participação ativa na cena processual, vigendo o princípio nemo iudex sine actore. O direito germânico antigo (século VII e anteriores) tem perfil de acusatório privado e suas principais características, de acordo com Maier, além da interação das partes no combate, eram a publicidade e a oralidade do procedimento ${ }^{81}$. Esta tradição encontrou terreno fértil nas Ilhas Britânicas, desenvolvendo-se no adversary, do qual trataremos oportunamente ${ }^{82}$.

Temos nas civilizações ateniense, romana republicana e feudal uma estrutura de delito que condicionará o processo de punição: a tradição do delito como conflito $^{83}$, em oposição à tradição do delito como infração, como desobediência à norma estatal, que veremos com mais apuro no item acerca do processo inquisitório ${ }^{84}$.

\footnotetext{
${ }^{80}$ DAMAŠKA, M. The faces of justice... loc. 3824 of 6774.

${ }^{81}$ MAIER, J.B. op. cit. p. 264 e seguintes. "I. Tribunal popular. II. Persecución penal privada en manos del ofendido y su parentela. III. Publicidad e oralidad del juicio en que se enfrentaban el acusador y su acusado. IV. Sistema de prueba tendiente a dirimir subjetivamente la contienda en tanto erigía un vencedor, ya porque presentaba mejores testimonios de su fama u honor personal, o porque vencía en el duelo o combate judicial, o porque pasaba con fortuna ciertas pruebas (ordalías o juicios de Dios), métodos mediante los cuales la divinidad mostraba, por signos físicos fácilmente observables, la justicia del caso. V. Decisión inimpugnable."

${ }^{82}$ Idem. Ibidem. p. 301. e PRADO, G. op. cit. p. 79 e seguintes.

${ }^{83}$ BINDER, A.M. op. cit. p. 273 e seguintes.

${ }^{84}$ Interessante passagem de Foucault que ilustra a concepção do delito como conflito e a passagem para a concepção do delito como infração: "Na alta Idade Média não havia poder judiciário. A liquidação era feita entre indivíduos. Pedia-se ao mais poderoso ou àquele que exercia a soberania não que fizesse justiça, mas que constatasse, em função de seus poderes políticos, mágicos e religiosos, a regularidade do procedimento. Não havia poder judiciário autônomo, nem mesmo poder judiciário nas mãos de quem detinha o poder das armas, o poder político. Na medida em que a contestação judiciária assegurava a circulação dos bens, o direito de ordenar e controlar essa contestação judiciária, por ser um meio de acumular riquezas, foi confiscado pelos mais ricos e poderosos." FOUCAULT, M. A verdade e as formas jurídicas. p. 65.
} 
A partir do século $\mathrm{XV}$, a formação das monarquias nacionais e a expansão da Santa Sé na Europa continental concentraram novamente o poder político e a burocracia clerical, ancorada na conveniente ressurreição da tradição romana imperial. A construção do processo punitivo daí em diante ficará marcada pela intervenção estatal direta, em um procedimento desenvolvido sofisticadamente para punir a heresia e que serviu à Igreja e ao Estado para também punir qualquer tipo de infração. Assistimos ao declínio das tradições gregas e romanas republicanas que, embora não tenham deixado de existir, principalmente no sistema anglo-saxão, acabam por dar lugar a uma justiça que, ao ver o delito como infração (Binder), implementa uma política de segurança do Estado (Damaška).

É interessante notar que, muito embora o sistema inquisitório tenha dominado as formas jurídicas de persecução penal na Europa continental desde o fim da Idade Média até nossos dias, o sistema acusatório sempre foi visto como teoricamente superior, como nos explica Damaška: "More interestingly, the inquisitorial process, although in practice dominant, was regarded as an anomaly or an aberration from regular forms. In its infancy, it required protection by extensive justification, even apologies: as departure from revered tradition, it was to be used only exceptionally - a necessary evil if the war against crime were to be successfully fought (ne crimina maneat impunita)" ${ }^{85}$. Em outra passagem, Damaška cita que "scholarly discussion of the inquisitorial procedure was regularly interspersed with ceremonial genuflection before an alternative design of criminal prosecution that always required a complainant, and readily evoked the idea of a dispute ${ }^{86}$.

De tempos em tempos, a tradição do delito como conflito e da justiça que propõe resolvê-lo sobrepõe a tradição de implementação de política estatal. O advento do Iluminismo, que "redescobre" o indivíduo e afirma seus direitos fundamentais ${ }^{87}$ na formulação do conceito de dignidade humana, superou a noção da segurança do Estado como princípio máximo do processo penal, colocando ao seu lado (ou acima) a necessidade de se evitar condenações de inocentes e a necessidade de garantir o máximo de

\footnotetext{
${ }^{85}$ DAMA ̌̌KA, M. The faces... loc 3863 of 6774.

${ }^{86}$ Idem. Loc 3867 of 6774.

${ }^{87}$ ILLUMINATI, G. op.cit. p. 303.
} 
imparcialidade dos Tribunais $^{88}$. O pensamento racionalista estabeleceu o sistema acusatório como "uma típica expressão de um regime democrático" 89 . A ideia foi resgatar o Direito Romano Republicano e receber a influência do sistema inglês (que sofreu pouca ou nenhuma contaminação do Direito Canônico) para um novo sistema de Justiça Penal. Diz Julio Maier que “El nuevo modelo proponía, en lugar de la escritura y el secreto de los procedimientos, de la negación de la defesa y de los jueces delegados del poder imperial, la publicidad y oralidad de los debates, la libertad de la defensa y el juzgamiento por jurados $\$ 90$. A prisão preventiva foi especialmente criticada ou racionalizada por iluministas como Mostequieu, Voltaire e Baccaria. As ideias liberais racionalistas, em suma, pensaram um sistema de justiça em que o Estado e o acusado disputavam perante um tomador de decisões independente do governo ${ }^{91}$.

A lei processual penal de 1791, primeira codificação processual penal da Revolução ${ }^{92}$, compreendeu o antagonismo diante dos princípios inquisitórios do Ancien Régime dispostos na anterior Ordenança de 1670. Existia a prisão preventiva decidida pelo juiz de paz (que era um magistrado instrutor), mas se admitia a liberdade mediante caução. Os debates tornaram-se orais e públicos. Este Código representou o primeiro passo para a reforma do sistema inquisitivo, mas ainda conferia bastante poder aos "magistrados de segurança" (juiz de paz), incorrendo no vício inquisitório da confusão entre acusação e defesa $^{93}$.

A codificação napoleônica - da forma ambígua que caracterizou seu criador - embora tenha tido o intuito de restabelecer algumas das características acusatórias, desenvolveu-se de forma a que o inquisitorialismo tivesse proeminência, situação que se conservou até o século XX.

\footnotetext{
${ }^{88}$ MAIER, J.B. op. cit. 86.

${ }^{89}$ ILLUMINATI, G. op. cit. p. 300.

${ }^{90}$ MAIER, J.B. op. cit. p. 336.

${ }^{91}$ DAMAŠKA, M. The faces... loc 3892 of 6774.

92 Após os decretos de 8 e 9 de outubro de 1789 da Assembleia Constituinte que impuseram a publicidade dos processos e a defesa do acusado em todos os graus de jurisdição. Cf. FERRAJOLI, L. op. cit. p. 136 e MAIER, J.B. op. cit. 340 e seguintes.

${ }^{93}$ MAIER, J.B. op. cit. 137.
} 
O modelo acusatório só veio ganhar força a partir da segunda metade do século XX, após a Segunda Grande Guerra ${ }^{94}$, quando se inicia um movimento de reforma dos sistemas de justiça penais para abrandar o modelo inquisitório como uma resposta aos regimes totalitários derrotados. A característica marcante da época foi um fortalecimento dos direitos de dignidade individuais e, consequentemente, uma proteção melhor ao acusado. Vemos o surgimento da Declaração Universal dos Direitos Humanos em 1948, o Pacto Internacional dos Direitos Civis e Políticos e o Pacto Internacional dos Direitos Econômicos, Sociais e Culturais, em 1966, e a Convenção Americana de Direitos Humanos em 1969. Em 1950, a Convenção Europeia sobre Direitos Humanos introduziu conceitos processuais penais marcadamente anglo-saxões como o "juízo equitativo" e os "direitos de oposição" artigo $5^{\circ}$, parágrafo $4^{\circ}$ da Convenção ${ }^{96}$ como o direito do acusado detido provisoriamente a um processo adversarial que garanta a paridade de armas do acusador e do acusado ${ }^{97}$. Seria, na expressão de Diogo Malan, um "direito ao confronto" "98. Trata-se de um importante passo na gradual conquista histórica de direitos de que falamos na introdução deste trabalho. Um exemplo desse movimento é a Constituição da República Italiana de

94 É de se consignar o projeto de Código processual penal (Entwurf einer Strafprozessordnung Goldschmidt/Schiffer), elaborado pelo jurista alemão James Goldschmidt ainda antes da Primeira Guerra Mundial que, em 1919, foi apresentado pelo Ministro da Justiça da República de Weimar Eugen Schiffer ao Senado, que não o aprovou. De acordo com Aury Lopes, "em seu Projeto, Goldschmidt previu a consequente efetivação do processo acusatório por meio da eliminação dos resquícios do processo inquisitório. Além disso, o projeto previu a possibilidade de recursos a todas as instâncias penais e a participação geral de leigos na primeira instância, no âmbito do Tribunal do Júri (tendo em vista, aqui, seu vasto conhecimento do modelo processual francês). Goldschmidt procurou vincular à prisão preventiva pressupostos muitos específicos para a sua decretação." O projeto "inspirou substancialmente" o "Projeto de Lei para Reorganização dos Tribunais Penais" apresentado pelo Ministro de Weimer e também jurista Gustav Radbruch LOPES Jr., A.; SILVA, P. R. A. da. Breves apontamentos... p. 176.

${ }^{95}$ DAMAŠKA, M. Aspectos... p.1.

96 4. Qualquer pessoa privada da sua liberdade por prisão ou detenção tem direito a recorrer a um tribunal, a fim de que este se pronuncie, em curto prazo de tempo, sobre a legalidade da sua detenção e ordene a sua libertação, se a detenção for ilegal.

${ }^{97}$ Caso Piruzyan vs. Armenia, julgado em 26 de setembro de 2012, notadamente o item 116, in verbis: “ 116. The Court reiterates that Article $5 \$ 4$ requires that a court examining an appeal against detention provide guarantees of a judicial procedure. The proceedings must be adversarial and must always ensure "equality of arms" between the parties, the prosecutor and the detained person. Equality of arms is not ensured if counsel is denied access to those documents in the investigation file which are essential in order effectively to challenge the lawfulness of his client's detention (see Lamy v. Belgium, 30 March 1989, § 29, Series A no. 151; Nikolova v. Bulgaria [GC], no. 31195/96, \& 58, ECHR 1999-II; and Garcia Alva v. Germany, no. 23541/94, $\$ 39$ 39 $13 \quad$ February 2001)." $\quad$ Disponível em http://hudoc.echr.coe.int/sites/eng/pages/search.aspx?i=001-111631. Acessado em 12 de setembro de 2014. ${ }_{98}$ MALAN, Diogo Rudge. Direito ao confronto no processo penal. 
1948, que já trazia o desenho de "um sistema processual baseado na iniciativa das partes e na prova colhida pela cross examination das testemunhas perante um juiz imparcial"99.

Com os documentos mencionados e com as novas constituições europeias continentais do pós-guerra, temos a instituição de Estados Democráticos de Direito tendo o modelo autenticamente acusatório de justiça criminal como o adequado a esta formulação constitucional. Nos regimes representativos - como o são todos os Estados Democráticos de Direito - o poder do juiz não passa de uma delegação do cidadão ${ }^{100}$, e é limitado pelas leis promulgadas em nome do cidadão.

Na formulação de Goldschmidt, "el proceso acusatorio ha configurado el proceso penal según el modelo del proceso civil como un "actus trium personarum". Como o autor da ação civil pede a adjudicação de um direito próprio, o acusador pede o exercício do direito judicial de punir (direito judicial de condenação e execução da pena $)^{101}$. Goldschmidt entendia que se trata de um direito potestativo que o Estado exerce contra si (jurisdição) intencionando uma sentença condenatória, mas só e somente só através de um processo, cuja exigência é inerente ao Estado de Direito que correlacionou o princípio da "nulla poena sine lege" ao de "nulla poena sine judicio". A ação penal deve, então, ser exercida pelo próprio Estado (ou pelo querelante ou pelo povo, no caso da ação penal popular) em face do próprio Estado, titular da jurisdição (Estado-juiz). Esta formulação está na base da separação de funções entre julgador, acusação e defesa ${ }^{102} . O$ processo acusatório é, por natureza e por oposição à inquisição, litigioso ${ }^{103}$. À inquisição

99 PANZAVOLTA, M. op. cit. p. 610. O movimento de contrarreforma empreendido pela Corte Constitucional fez com que a constituição tivesse que ser emendada (ver item 4.1)

${ }^{100}$ DAHL, Robert A. Sobre a democracia. p. 128.

${ }^{101}$ Op. cit. p. 28/35.

${ }^{102}$ Os críticos desta formulação argumentam que desta forma não haveria uma diferença clara entre processo penal e civil, podendo o promotor deduzir seu pedido perante um juiz cível. Goldschmidt responde que depois da publicização da pena, o processo penal passou a ter suas próprias categorias, (o direito de apenar pode ser exercido exclusivamente pelo processo penal, o direito privado pode se realizar por outros meios). A parte acusadora do processo penal não demanda um direito próprio, mas o direito do próprio Estado de punir (o direito de punir é do Estado e só do Estado). Goldchmidt critica, inclusive, a expressão da "ação penal" do art. 100 da Ley de Enjuiciamiento Criminal espanhola de 1882 e vigente até hoje. O direito não é do acusador, mas do próprio Estado que julga.

${ }^{103}$ GOLDSCHMIDT, J. op. cit. 69. Dizer que o processo acusatório é litigioso, como faz Goldschmidt, não implica que haja lide no processo penal, mas simplesmente uma contenda (contencioso). Grande parte da doutrina entende que lide (pretensão resistida) não existe no processo pelo simples fato de que a pena não pode ser aplicada sem processo, i.e., o Estado, titular exclusivo do ius puniendi, só deve fazê-lo por meio do processo. Neste sentido BADARÓ, G.H.R.I. Correlação entre acusação e sentença.; LOPES Jr., A. Direito processual penal. p. 87; DIAS, J.F. op.cit. p.64. 
de nada interessa a contenda entre as duas partes e o procedimento - que já existia na época - da causa por acusação, porque tornaria o processo longo e "litigioso"104.

É possível dizer que o objetivo das reformas processuais penais pelas quais passou a quase totalidade dos Estados da Europa continental e da América Latina foi “tornar operacionais as garantias declaradas nas várias Constituições e nas Convenções Internacionais de Direitos Humanos" "105, instalando-se um processo penal em que o acusatório fosse, de fato, operante, e não simplesmente uma máscara do sistema inquisitório. Este processo tornou-se ainda mais forte nas últimas décadas do século XX na Itália, na Espanha, em Portugal e na América Latina.

Damaška identifica duas fontes de pressão que impulsionam a reforma: a) a pragmática, que consiste na racionalização do sistema penal que não suporta tantos casos; b) a questão ideológica, de princípio, de fortalecimento dos direitos individuais dos réus ${ }^{106}$.

Deste processo, destacamos o traço principal de tornar os sistemas de justiça menos especificamente punitivos e mais garantidores dos direitos individuais, fazendo com que se fortaleça a imparcialidade do julgador. O juiz deve ter um papel de resolutor de conflitos entre o Estado acusador e o réu, em contraste com o papel do responsável pela política de segurança pública do Estado. Dentre as características principais que servirão para a análise do tema do presente trabalho destacamos: a) a separação clara e eficiente entre a fase de investigação e a fase do processo (tema caro aos italianos, mas relevante para todos os outros); b) a produção de prova de forma oral e inteiramente nas mãos das partes em frente a um juiz imparcial ${ }^{107}$ em um procedimento denominado "juízo oral” (expressão da ordem do dia do processo penal latino-americano e espanhol, mas que, no Brasil, é pouco utilizada) ${ }^{108}$; c) o fortalecimento do princípio da presunção de inocência, com requisitos mais ligados à cautela processual possíveis das

\footnotetext{
${ }^{104}$ Manual de inquisidores. p. 2.

${ }^{105}$ PRADO, G. op. cit. p. 64.

${ }^{106}$ DAMAŠKA, M. Aspectos... p.1.

${ }^{107}$ PANZAVOLTA, M. op. cit. 610. "What makes a system accusatorial is the fact that evidence is collected in oral form with adversary dynamics in front of an impartial judge.".

${ }^{108}$ Prefere-se, aqui, a expressão "juízo oral” em lugar de "audiência”. Juízo oral, da forma como é entendido na América Latina e na Espanha, é mais que um simples ato a mais no procedimento penal, é mais que uma audiência. Com a ideia de evitar a escrituração e a burocracia processual, o juízo oral se torna o núcleo duro do procedimento penal, pois é o método de coleta de provas, compreendendo proposição, contenda e discussão em frente ao juiz imparcial.
} 
medidas restritivas que ocorrem antes da decisão final; d) a horizontalização do sistema de justiça $^{109}$.

Especificamente quanto à presunção de inocência, a segunda metade do século XX assistiu à positivação constitucional deste dispositivo ${ }^{110}$, como fizeram a Constituição Francesa de 1958 (que reintroduziu as disposições da Declaração dos Direitos do Homem e do Cidadão de 1789 que proclamava a presunção de inocência no art. $9^{\circ}$ ), a Constituição Italiana de 1948 (art. 27, parágrafo 2º a portuguesa de 1976 (art. 32, parágrafo $2^{\circ}$ ), a espanhola de 1978 (artigo 24, parágrafo $2^{\circ}$ ) e a Lei Fundamental alemã de 1949 (artigo 20, parágrafo $3^{\text {}}$ ). A presunção de inocência como "princípio-garantia" estabelece o primado dos limites de estabelecimento de sanções, ou seja: a) ninguém pode ser considerado culpado sem o devido processo legal; b) “nenhuma condenação será proferida sem prova de culpabilidade"; c) o acusado não pode ser sujeito a qualquer tratamento equiparado ao do culpado ${ }^{111}$. Entender a prisão preventiva como uma medida processual, vinculada aos fins do processo, é um passo dado pela nova ciência penal a partir do desenvolvimento do sistema acusatório ${ }^{112}$.

Grande exemplo do movimento de reforma é a promulgação do Código de Processo Penal na Itália em 1988. Uma síntese da diferença do método inquisitivo para o acusatório é encontrada quando Panzavolta trata da ideologia do Código Italiano de 1988: "Cultural factors were the determinate factor limiting the effectiveness of the new Code. The ideology of the 1988 Code was the converse of the traditional model of criminal law and procedure in Italy. The traditional model was premised on the assumption that an impartial, capable researcher could best ascertain the facts of a case. By contrast, the new Code is rooted in the premise that there is not an objective way to ascertain facts or

\footnotetext{
${ }^{109}$ Esta última característica é mais voltada aos sistemas recursais extremamente copiosos. A ideia de uma justiça horizontal em que as conclusões de fato são tomadas no juízo oral repele uma justiça vertical na qual as decisões são constantemente revistas, algumas vezes com métodos diferentes. Como se tratará mais à frente, hoje no Brasil há um método de coleta de provas na primeira instância que se aproxima de um juízo oral (a audiência una do art. 400 do Código de Processo Penal) e outro método para se rever o conjunto probatório em fase de apelação (leitura de documentos).

${ }^{110}$ GOMES F., A.M. Presunção de inocência e prisão processual na lei 12.403, p. 437.

${ }^{111}$ Idem. Ibidem. p. 439.

${ }^{112}$ MACIÁ GOMEZ, R.; ROIG ALTOZANO, M. El nuevo sistema de adopción de la medida cautelar de la prisión provisional. p. 77.
} 
conclusions, but that truth is best found through confrontation of differing points of view"113.

Quando foi colonizada, a América Latina herdou por completo o direito europeu essencialmente inquisitório: o Brasil recebeu as Ordenações Filipinas; a maioria dos países hispânicos seguiu aplicando a Ley de las Siete Partidas; Cuba ainda era colônia ao tempo da entrada em vigor da Ley de Enjuiciamiento Penal (1882) e a República Dominicana fez vigorar em seu território o Códe d'instruction criminelle de $1808^{114}$. O sistema inquisitivo dominou o processo penal latino-americano após os movimentos de independência por mais de um século e meio e só foi seriamente ameaçado 150 anos depois da independência dos Estados americanos, com a redemocratização dos anos 80 e início dos anos $90^{115}$. Iniciou-se, então, um processo de mudança do sistema de justiça, espelhando-se na América Latina o que ocorrera na Europa do século XIX. "No processo penal se observa a tendência de substituir o tradicional processo inquisitivo escrito por formas de juízo oral próprios de um Estado de Direito" ${ }^{116}$. Ocorre a redução do poder do juiz e a observação maior das garantias do réu. Segundo Alberto Binder, as reformas ocorridas nos 30 primeiros anos após a redemocratização insistiram tenazmente em deixar a inquisição para trás ${ }^{117}$. De acordo com Struensee e Maier, a grande reforma por que passaram os processos penais latinoamericanos não tratou de modificações parciais, mas sim da entronização de uma nova concepção de processo penal. "Descrito sistématicamente, se puede decir que este proceso de reformas consiste en derogar los códigos antiguos, todavía tributarios de los últimos ejemplos de la Inquisición - recibida con la conquista y la colonización del continente -, para sancionar, en más o en menos, leyes procesuales penales conformes al Estado de Derecho, con la aspiración de recibir en ellas la elaboración cumplida en la materia durante el siglo XX."

\footnotetext{
113 op. cit. p. 604.

${ }^{114}$ STRUENSEE, Eberhard; MAIER, Julio B. J. Introdución in Las reformas. p. 22.

115 Evidentemente há mudanças mais ou menos importantes nos sistemas processuais penais durante os 150 primeiros anos dos Estados independentes. No Brasil, por exemplo, foi introduzido um instituto nascido e desenvolvido na common Law, o júri. Porém, ainda assim, em nosso entender, não seria inadequado sustentar que as modificações estruturais mais relevantes ocorreram apenas após a redemocratização dos anos 80 e 90. A relevância das reformas pós-redemocratização serão salientadas oportunamente.

${ }_{116}$ AMBOS, K.; CHOUKR, F. H. A reforma do processo penal no Brasil e na América Latina. p. 224.

${ }^{117}$ BINDER, A. M. op. cit. p. 256.

${ }^{118}$ STRUENSEE, Eberhard; MAIER, Julio B. J. Introdución in Las reformas. p. 17
} 
“Estas reformas - diz Geraldo Prado - são compatíveis com a transição para a Democracia, mudam a face do processo penal e embora realizadas a partir do início dos anos 90, não foram ainda concluídas" e encontram barreiras importantes como a persistência da mentalidade inquisitória, a falta de recursos para o fortalecimento das instituições acusatórias (Ministério Público, Defensoria e Magistratura imparcial e independente) e o ensino jurídico ainda ligado à exposição técnico-jurídica e aos métodos inquisitórios ${ }^{119}$.

Destaca-se o fenômeno - que, como se pode concluir, é o fenômeno que determina o problema analisado no presente trabalho - do descompasso das Constituições que começaram a entrar em vigor no último quartel do século $\mathrm{XX}^{120}$ ("inclinadas hacia el liberalismo de cuño estadunidense") com os códigos antigos e seus juízes inquisidores, estrutura rigidamente verticalizada e escassas garantias individuais típicas do Estado de Direito $^{121}$.

Os trabalhos da Universidade de Córdoba e o Código de Processo Penal de 1940 daquela província, a que deram origem, passaram a influenciar muitos países da América Latina, e culminaram na criação do Instituto Ibero-americano de Direito Processual e nas Jornadas do Rio de Janeiro de 1988, quando foi criado o Código de Processo Penal modelo para a Ibero América ${ }^{122}$. Este projeto influenciou profundamente vários códigos, como o guatemalteco, vigente desde 1994, o costarriquenho, de 1998, e a reforma mais radical no sistema de justiça penal já vista na América Latina, que foi a chilena, no início do século $\mathrm{XXI}^{123}$, além de outros ordenamentos processuais penais, como em várias províncias da Argentina, El Salvador, Venezuela, Bolívia e Paraguai. "As inovações trazidas pelos projetos incidem profundamente no sistema processual penal vigente, modernizando-o e adequando-o ao modelo acusatório, em que as funções de acusar, defender e julgar devem ser atribuídas a órgãos diversos, no respeito integral ao

\footnotetext{
${ }^{119}$ PRADO, G. op. cit. p. 63 e seguintes.

120 Apenas para citar algumas: a Constituição Política da República do Chile de 1980; a Constituição da República Oriental de Uruguay de 1997; a Constituição Política do Peru de 1993; a Constituição Política da Colômbia de 1991; Na Argentina ainda vigora a Constitución de la Nación de 1853, mas esta sofreu várias reformas essenciais, sendo a última de 1994; A Bolívia somente conseguiu suplantar a constituição ditatorial de 1967 em 2009; A Costa Rica foi pioneira, como em muitos outros temas das liberdades individuais, aprovando sua Constituição de 1949.

${ }^{121}$ STRUENSEE, Eberhard; MAIER, Julio B. J. Introdución in Las reformas. p. 18.

122 Elaborado principalmente pelos juristas Jaime Bernal, Fernando de La Rua, Ada Pellegrini Grinover e Julio Maier.

${ }^{123}$ STRUENSEE, Eberhard; MAIER, Julio B. J. Introdución in Las reformas. p. 28 e seguintes.
} 
contraditório". Nos códigos reformados realça-se que: "na investigação criminal, deixamse perfeitamente caracterizadas a função da polícia, encarregada das investigações; do Ministério Público, destinatário da investigação, com atribuições de supervisão $e$ controle; do juiz, imparcial e equidistante, para a concessão das medidas cautelares; da defesa, assegurada a partir do indiciamento; do ofendido que pode exercer diversas atribuições" $"$ ". Mais recentemente, o Centro de Estudios de Justicia de las Américas $(C E J A)^{125}$, órgão da Organização dos Estados Americanos, vem estudando seriamente e impulsionando as reformas processuais penais na América Latina.

Um dos institutos processuais particularmente revistos pelas reformas foi a prisão preventiva. Sob a perspectiva estritamente legislativa, foi praticamente suprimida a prisão preventiva automática ${ }^{126}$, e seus requisitos foram sendo voltados cada vez mais à segurança do próprio processo. Entretanto, o problema mais fundamental que ainda persiste nos sistemas latino-americanos é, nas palavras da Comissão Interamericana de Direitos Humanos, o uso excessivo, arbitrário e ilegal da prisão preventiva como uma desfuncionalidade do sistema de justiça, causando problemas como a superlotação e a mistura entre presos condenados ${ }^{127}$. Este trabalho foca seu discurso para a questão da arbitrariedade.

\subsubsection{Características definidoras do sistema acusatório}

\subsubsection{A imparcialidade do juiz}

A partir da perspectiva histórica delineada acima, concluímos que o papel do juiz penal no contexto de um modelo acusatório tem como principal traço a resolução do conflito, em oposição ao controle social ou a implementação de política pública. A principal característica do juiz, portanto, é a imparcialidade ${ }^{128}$ e, para se alcançar tal

\footnotetext{
${ }^{124}$ CINTRA, A. C. A.; GRINOVER, A. P.; DinAmARCO, C. R. Teoria Geral do Processo. p. 126.

125 www.cejamericas.org

126 RIEGO, C.; DUCE, M. (directores de la investigación y editores). Prisión preventive y reforma procesal penal en América Latina. p. 16 e seguintes. Interessante notar que uma das notas características do novo Código Português de 87 foi a revogação da incaucionabilidade: Diz o texto introdutório de 87: "Realmente, o princípio da caucionabilidade abstracta de todas as infracções é o que se adequa com o direito fundamental da liberdade pessoal. Pressupõe, aliás, uma reafirmação de confiança nos critérios dos juízes; trata-se de uma outorga de confiança que constituirá um elemento matricial de um Estado de direito."

${ }^{127}$ Informe sobre el uso de la prisión preventiva en las Américas. p. 10.

128 "El sistema acusatorio se caracteriza por exigir una configuración tripartita del proceso, con un acusador, un acusado y un tribunal imparcial que juzga y cuyo objetivo es garantizar la imparcialidad 
atributo, deve-se dispensar o juiz da persecução penal ${ }^{129}$ e fazer valer o princípio - antes confinado no processo civil, mas recebido pelo processo penal através do desenvolvimento do acusatório - do ne procedat iudex ex officio ${ }^{130}$. O princípio acusatório e o sistema que dele advém importam da separação radical das autoridades estatais encarregadas da investigação e as encarregadas da decisão, embora conservando um padrão de dependência mútua ${ }^{131}$. De acordo com Gimeno Sendra, o acusatório não só significa a precedência (no sentido temporal) da acusação sobre a defesa para que esta tome conhecimento e tenha a chance de responder ("nemo iudex sine acusatore"), como o desdobramento das funções de acusação e decisão, que devem ser outorgadas a sujeitos processuais distintos, "lo que no resulta admisible es la atribuición al juzgador de la possibilidad de sancionar infracciones penales, ni siquiera faltas, em caso de inexistencia de pretensión acusadora" ${ }^{132}$.

Como colocam Grinover, Araújo Cintra e Dinamarco, “quanto aos poderes de fundo propriamente jurisdicional, é uma questão de política legislativa concedê-los em maior ou menor quantidade e intensidade ao juiz; caracteriza-se o processo de ação (ou acusatório) pelo equilíbrio do poder do juiz com a necessidade de provocação das partes e acréscimo dos poderes destas. Nosso processo é do tipo do processo de ação, tanto em matéria civil como penal." ${ }^{133}$ Seguem Ambos e Choukr sustentando que "na acusatoriedade, a partição nítida de funções é ponto basilar, distinguindo-se qual o papel a ser desenvolvido por cada um dos agentes da persecução penal e o tratamento dispensado ao investigado"134.

Entretanto, esta dispensa da persecução penal não se esgota na exclusividade do Ministério Público para oferecimento da denúncia, tornando o juiz o senhor do processo até a decisão final, com poderes instrutórios e cautelares de ofício.

aunque pueda peligrar la persecución o al menos quedar sometida a variaciones por efecto del ejercicio de la discrecionalidad." ARMENTA D., T. op. cit. p. 22.

${ }^{129}$ GOLDSCHMIDT, J. op. cit. 28.

${ }^{130}$ BADARÓ, G.H.R.I. Correlação entre acusação e sentença. p. 36. " $O$ ne procedat iudex ex officio nada mais é do que corolário ou consequência do direito de ação. E, reflexo de ambos, surge a vedação do juiz pronunciar-se sobre algo que não integrou o objeto do processo, isto é, a proibição de que o juiz profira um provimento sobre matéria que não foi trazida ao processo quando uma das partes exerceu o direito de ação; o juiz estaria agindo de ofício e violando a regra da inércia da jurisdição".

${ }^{131}$ HASSEMER, W. op. cit. p. 220.

${ }^{132}$ GIMENO Sendra. El Derecho Fundamental a un Proceso Acusatorio. p. 270/271, grifos no original.

${ }^{133}$ CINTRA, A.C.A.; GRINOVER, A.P.; DINAMARCO, C. R. Teoria Geral do Processo. p. 165.

${ }^{134}$ AMBOS, K.; CHOUKR, F. H. A reforma do processo penal no Brasil e na América Latina. p. 18. 
Dito de outra forma, um sistema acusatório significa muito mais do que impedir que o juiz inicie um processo penal. Mesmo a inquisição que vigia na Espanha admitia - embora não preferisse - a formação de causa por acusação ${ }^{135}$.

Para que a garantia do acusatório seja plena, deve ser dada relevância especial à imparcialidade do julgador. Assim o determina literalmente o parágrafo $1^{\circ}$ do art. $8^{\circ}$ da Convenção Americana de Direitos Humanos ${ }^{136}$ e o art. $10^{\circ}$ da Declaração Universal de Direitos Humanos ${ }^{137}$, além do art. $2^{\text {o }}$ do Código de Processo Penal modelo para a Ibero-américa ${ }^{138}$. "A imparcialidade é garantida pelo modelo acusatório e sacrificada no sistema inquisitório, de modo que somente haverá condições de possibilidade da imparcialidade quando existir, além da separação inicial das funções de acusar e julgar, um afastamento do juiz da atividade investigatória/instrutória." "139 $\mathrm{O}$ sistema acusatório, partindo da ideia de heterocomposição ("por meio da qual um terceiro imparcial substitui a autonomia das partes. ${ }^{, 140}$ ), desdobra o Estado em acusador e juiz, aquele com interesse e este com imparcialidade.

Deve-se partir, no entanto, do princípio de que a imparcialidade plena é algo difícil - se não impossível - de se alcançar. Badaró assinala a dificuldade de se garantir a imparcialidade de todos os julgadores, tendo em conta a diversidade de concepções políticas e contextos sociais e históricos. O juiz puramente imparcial, sustenta o doutrinador, assim como idealizado pelos iluministas, simplesmente não existe ${ }^{141}$.

Neste ponto é preciso lembrar a teoria da imparcialidade desenvolvida pelo Tribunal Europeu de Direitos Humanos (TEDH) que, interpretando o parágrafo $1^{\circ}$ do

\footnotetext{
${ }^{135}$ Manual de inquisidores, p. 2. "Formase causa por acusacion cuando se ofrece el delator á probar lo que dice, sujetandose á la pena de talion en caso de no dar pruebas."

136 "1. Toda pessoa tem direito a ser ouvida, com as devidas garantias e dentro de um prazo razoável, por um juiz ou tribunal competente, independente e imparcial, estabelecido anteriormente por lei, na apuração de qualquer acusação penal formulada contra ela, ou para que se determinem seus direitos ou obrigações de natureza civil, trabalhista, fiscal ou de qualquer outra natureza."

137 "Artigo $10^{\circ}$. Toda a pessoa tem direito, em plena igualdade, a que a sua causa seja equitativa e publicamente julgada por um tribunal independente e imparcial que decida dos seus direitos e obrigações ou das razões de qualquer acusação em matéria penal que contra ela seja deduzida."

138 “Art. $2^{\circ}$ Juiz imparcial. O julgamento e a decisão das causas penais será feito por juízes imparciais e independentes dos poderes do Estado, apenas sujeitos à lei..."

${ }^{139}$ LOPES Jr., A. Processo penal. p. 116.

${ }^{140}$ Idem ibidem.

${ }^{141}$ BADARÓ, G.H.R.I. Processo Penal. p. 8.
} 
art. $6^{\circ}$ da Convenção Europeia de Direitos Humanos ${ }^{142}$, e partindo da ideia enunciada acima - de que o atributo da imparcialidade é de difícil alcance -, separou o conceito de imparcialidade em subjetiva e objetiva já na década de 1980 em dois casos paradigmáticos. No primeiro, Piersack vs. Bélgica, de 1982, o TEDH deparou-se com a circunstância de ter um juiz da corte de segunda instância (Brabant Assize) julgado o recurso do réu mesmo tendo tido no passado um cargo de relevância no Ministério Público (procureur du Roi), ao tempo em que o mesmo caso era investigado. A corte entendeu que o fato maculava a imparcialidade objetiva do juiz que consiste no oferecimento de garantias suficientes que excluam qualquer dúvida legítima a respeito da imparcialidade do juízo ${ }^{143}$. No segundo caso, de Cubber vs. Bélgica, de 1984, a mesma situação (juízes envolvidos previamente com a investigação na qualidade de acusadores) o TEDH reforçou a jurisprudência de Piersack sustentando que, embora não se possa afirmar a parcialidade dos juízes penais no caso específico, o fato da mesma pessoa servir como investigador e juiz fundamentava dúvidas legítimas ao acusado ${ }^{144}$. Interpretando as decisões do TEDH, Gimeno Sendra sustenta que "el Tribunal debe ser subjetivamente imparcial, esto es, ningúm miembro del tribunal debe tener ningún prejuicio o predisposición personal acerca de la culpabilidad

\section{${ }^{142}$ Artigo 6. ${ }^{\circ}$}

(Direito a um processo equitativo)

1. Qualquer pessoa tem direito a que a sua causa seja examinada, equitativa e publicamente, num prazo razoável por um tribunal independente e imparcial, estabelecido pela lei, o qual decidirá, quer sobre a determinação dos seus direitos e obrigações de carácter civil, quer sobre o fundamento de qualquer acusação em matéria penal dirigida contra ela. $\mathrm{O}$ julgamento deve ser público, mas o acesso à sala de audiências pode ser proibido à imprensa ou ao público durante a totalidade ou parte do processo, quando a bem da moralidade, da ordem pública ou da segurança nacional numa sociedade democrática, quando os interesses de menores ou a protecção da vida privada das partes no processo o exigirem, ou, na medida julgada estritamente necessária pelo tribunal, quando, em circunstâncias especiais, a publicidade pudesse ser prejudicial para os interesses da justiça.

${ }_{43}$ "Whilst impartiality normally denotes absence of prejudice or bias, its existence or otherwise can, notably under Article $6 \$ 1$ (art. 6-1) of the Convention, be tested in various ways. A distinction can be drawn in this context between a subjective approach, that is endeavouring to ascertain the personal conviction of a given judge in a given case, and an objective approach, that is determining whether he offered guarantees sufficient to exclude any legitimate doubt in this respect." Disponível na íntegra em http://hudoc.echr.coe.int/sites/eng/pages/search.aspx?i=001-57557. Acessado em 4/4/2014.

144 " 30 . In conclusion, the impartiality of the Oudenaarde court was capable of appearing to the applicant to be open to doubt. Although the Court itself has no reason to doubt the impartiality of the member of the judiciary who had conducted the preliminary investigation (see paragraph 25 above), it recognises, having regard to the various factors discussed above, that his presence on the bench provided grounds for some legitimate misgivings on the applicant's part. Without underestimating the force of the Government's arguments and without adopting a subjective approach (see paragraphs 25 and 28 above), the Court recalls that a restrictive interpretation of Article 6 para. 1 (art. 6-1) - notably in regard to observance of the fundamental principle of the impartiality of the courts - would not be consonant with the object and purpose of the provision, bearing in mind the prominent place which the right to a fair trial holds in a democratic society within the meaning of the Convention." Disponível na íntegra em http://hudoc.echr.coe.int/sites/eng/pages/search.aspx?i=001-57465. Acessado em 4/4/2014. 
del acusado. Pero, em segundo lugar y sobre todo, el Tribunal debe ser tambiém imparcial desde un punto de vista objetivo, es decir, debe ofrecer suficientes garantías como para excluir cualquier duda legítima a este respecto, de tal suerte que, si, de las apariencias del Juez o de sus actos, puede la sociedad alcanzar serias dudas sobre su imparcialidad, se vulneraría el derecho al juez imparcial contenido em el art. 6.1 del CEDH"145.

De acordo com o próprio TEDH, a imparcialidade pode ser testada de várias maneiras, seja pelo lado subjetivo (que se presume enquanto não há provas em contrário), seja pelo lado objetivo (garantias que o juízo dá ao acusado de que é realmente imparcial). Por isso, quando se trata de imparcialidade, diz a Corte Europeia, "as aparências são importantes" 146 , de maneira que o juiz, além de ser imparcial, deve parecer imparcial, e parecer imparcial sobretudo ao réu e aos cidadãos em geral ${ }^{147}$. Trata-se, em realidade, de um “clima de isenção que deve permear as atividades judiciais", como diz Magalhães ${ }^{148}$. Jacinto Coutinho coloca que "há um algo mais para além da independência, ou seja, a impossibilidade de que se coloquem dúvidas quanto à sua imparcialidade. Em geral, os juízes não querem ser parciais (racionalmente falando e, portanto, no plano da consciência), tratando de agir dentro de tais parâmetros. O que se não quer, enfim, é que se coloque em dúvida a imparcialidade"149.

\footnotetext{
${ }^{145}$ GIMENO S., J.V. El Derecho Fundamental a un Proceso Acusatorio. p. 269. A dupla dimensão da imparcialidade judicial foi reafirmada pelo TEDH em Olujić v. Croatia, no. 22330/05, §§ 57 et seq., 5 February 2009. Em interessantíssimo caso julgado pelo Tribunal de Relação da Bahia em $1^{\circ}$ de junho de 1875, entenderam os julgadores que "[n] ão fica inhibido de funccionar em um processo criminal, o Juiz que, na qualidade de Chefe de Policia, ordenou a instauração do mesmo processo e a prisão dos delinquentes." SALLES, J.R.C. Foro penal. p. 331.

${ }^{146}$ Brudnicka and Others v. Poland, no. 54723/00, § 41, ECHR 2005 II.

147 "Segundo a teoria da aparência geral de imparcialidade, para que a função jurisdicional seja legitimamente exercida, não basta que o magistrado seja subjetivamente imparcial, mas é necessário também que a sociedade acredite que o julgamento se deu perante um juiz imparcial. Um julgamento que toda a sociedade acredite ter sido realizado por um juiz parcial será tão pernicioso e ilegítimo quanto um julgamento realizado por um juiz intimamente comprometido com uma das partes. Consequentemente, tão importante quanto o juiz ser imparcial, é o juiz parecer ser imparcial. Se a sociedade não acredita que a justiça seja feita, porque ao acusado não foi assegurado um julgamento imparcial, o resultado de tal processo será ilegítimo e prejudicial ao Poder Judiciário. A sociedade não verá em tal sentença, pouco importando se absolutória ou condenatória, uma decisão justa". BADARÓ, G.H.R.I. Processo Penal. p. 10. ${ }^{148}$ GOMES F., A.M. Presunção de inocência e prisão processual na Lei 12.403, de 2011. p. 440.

${ }^{149}$ COUTINHO, J.N.M. op. cit. p. 13.
} 
Neste esteio, é de se recordar que em outros ordenamentos até mesmo o fato de um mesmo juiz condenar e fixar a pena já poderia ser motivo para se duvidar da imparcialidade de um juiz ${ }^{150}$.

A partir de em terceiro caso, Hauschildt vs. Dinamarca, de $1989^{151}$, a Corte Europeia deparou-se com o fato de um mesmo juiz tomar decisões cautelares processuais e, após, analisar o mérito da condenação. Embora tenha consignado que a cognição sumária das decisões cautelares e a cognição da condenação não podem ser tratadas como a mesma coisa, a imparcialidade objetiva do juízo pode não ser alcançada devido à "natureza dos atos por ele praticados"152 na fase de investigação.

Por fim, é importante consignar que o TEDH vem dispondo há tempo sobre a importância de mecanismos nacionais que garantam a imparcialidade "at removing any appearance of partiality and so serve to promote the confidence which the courts in a democratic society must inspire in the public"153.

Em conclusão, temos que as normas de um sistema acusatório devem evitar que o juiz penal tenha uma distorção acusatória (accusatory bias), ou seja, a tendência judicial, o pré-juízo, de aderir às teses do acusador, requerendo um standard menor para a condenação. Isso nada mais é do que um exemplo de superação do modelo inquisitório pelo acusatório, em que o juiz imparcial reativo que resolve um conflito substitui um juiz que tem a responsabilidade da política de segurança pública do Estado.

\subsubsection{A relevância do contraditório}

Anteriormente dissemos que o sistema acusatório importa, inter alia, em um modo de produção de provas adversarial ${ }^{154}$, ou seja, com partes em pé de igualdade à frente de um juiz isento e imparcial. O centro de gravidade processual, colocado no juiz nos modelos inquisitórios, é deslocado para as partes. Neste sentido diz-se que o processo acusatório é, essencialmente, um processo de partes $^{155}$. Como o juiz perde a posição de

\footnotetext{
${ }^{150}$ HASSEMER, W. op. cit. p. 152.

${ }^{151}$ Disponível em http://hudoc.echr.coe.int/sites/eng/pages/search.aspx?i=001-57500. Acessado em 4/4/2014.

${ }^{152}$ Expressão de BADARÓ, G.R.I. Processo Penal. p. 9.

${ }^{153}$ Mežnarić v. Croatia, no. 71615/01, § 27, 15 July 2005, Huseyn and Others v. Azerbaijan, nos. 35485/05, 45553/05, 35680/05 and 36085/05, § 162, 26 July 2011.

${ }^{154}$ Ver as duas definições de adversarial no item 1.1.4.

155 GIMENO S., J.V. El Derecho Fundamental a un Proceso Acusatorio. p. 271. No mesmo sentido, LOPES Jr. A. Processo penal. p. 536.: “Quando falamos de um processo de partes, estamos fazendo alusão a
} 
"gestor da prova"156, são as partes, com seus interesses contrapostos, que produzirão as provas com exclusividade. $\mathrm{O}$ exame das questões processuais não significa nada mais do que outorgar audiência às partes. Parte-se do princípio de que o melhor meio de se chegar à verdade ou à decisão justa é dar às partes a iniciativa de provocar o juízo e de aportar provas ${ }^{157}$. É este o movimento histórico que retira o réu de uma posição de objeto do processo para a posição de sujeito do processo, em igualdade de posição - ou na posição de maior equilíbrio possível, já que é impossível encontrar igualdade entre o indivíduo acusado de um delito e o Estado-acusador - com a acusação, à frente de um juiz imparcial - ou o mais imparcial e isento possível, como vimos acima.

Há, portanto, uma relação dialética entre as partes, de maneira que o pleito de uma parte deve ser contraposto à resistência da outra, e só assim o juiz pode chegar a uma decisão ${ }^{158}$. Pode-se dizer que o processo penal absorve a epistemologia desenvolvida na Escola de Frankfurt, em que a verdade não pode ser obtida por convicção ("adaequatio rei et intellectus"), mas construída por meio dialético ("teoria do consenso sobre a verdade"), em um "discurso livre de dominação"159.

Daí temos a definição de Joaquim Canuto Mendes de Almeida, segundo quem o contraditório é a "ciência bilateral dos atos e termos processuais e possibilidade de contrariá-los"160. No mesmo sentido, a definição de Aury Lopes Jr.: "o contraditório

um processo penal de partes, conforme os limites e categorias jurídicas próprias do processo penal. Acima de tudo, o que se busca é reforçar a posição da parte passiva, fortalecendo o sistema acusatório com o estabelecimento da igualdade de armas, do contraditório, e, por fim, com o abandono completo de todo e qualquer resíduo do verbo totalitário. Em última análise, significa o abandono completo da concepção do acusado como um objeto, considerando-se agora no seu devido lugar: como parte no processo penal." (grifo no original). No mesmo sentido, BADARÓ, G.H.R.I. Correlação entre acusação e sentença. p. 22: “ $O$ processo acusatório é essencialmente um processo de partes, no qual acusação e defesa se contrapõem em igualdade de posições, e que apresenta um juiz sobreposto a ambas. Há uma nítida separação de funções, fazendo com que o processo se caracterize como um verdadeiro actum trium personarum. $O$ contraditório deve informar todo o processo que, originalmente, se caracterizava como uma verdadeira luta de partes". Contrário a esta posição está Eugênio Pacelli de Oliveira que, com base na indisponibilidade subjetiva das partes, sustenta literalmente que o processo penal não é um processo de partes. O princípio acusatório e a nova prisão preventiva. Palestra proferida no X Seminário de Direito Militar.

${ }^{156}$ COUTINHO, J.N.M op. cit. p. 32.

${ }^{157}$ GOLDSCHMIDT. J. Op. cit. p. 69.

${ }^{158}$ Dialética é um termo filosófico equívoco na história do pensamento. A dialética como método consiste em "seeking knowledge by question and answer" cf. RUSSELL, B. A history of western philosophy. p. 92. Na visão hegeliana e, mais tarde, marxista, a dialética ganha a conceituação predominante na filosofia moderna e contemporânea como síntese dos opostos, e é neste sentido que utilizamos a expressão. Cf. ABBAGNANO, N. Dicionário de filosofia. p. 272 e seguintes. Diz Aury que "O contraditório conduz ao direito de audiência $e$ às alegações mútuas das partes na forma dialética." LOPES Jr. A. Direito Processual Penal. p. 145.

${ }^{159}$ HASSEMER, W. Op.cit. p. 186.

${ }^{160}$ ALMEIDA, J.C.M. op. cit. p. 82. 
deve ser visto basicamente como o direito de participar, de manter uma contraposição em relação à acusação e de estar informado de todos os atos desenvolvidos no iter procedimental" ${ }^{161}$.

O contraditório está expresso na Constituição Federal de 1988 (art. 5, inciso LV), que enuncia que "aos litigantes, em processo judicial ou administrativo, e aos acusados em geral são assegurados o contraditório e a ampla defesa, com os meios e recursos a ela inerentes".

Quanto ao tema aqui desenvolvido, a questão seria perquirir se o contraditório, como direito de participar, deve ser observado também neste "microprocesso" de que emerge a decisão da medida cautelar. Não há dúvida de que a decisão acerca de uma medida tão grave como a prisão preventiva, tão semelhante à prior sorte que o processo pode trazer ao acusado (a perda do direito fundamental à liberdade), não possa prescindir do contraditório. Esta é a conclusão a ser utilizada no curso deste trabalho. Mais sobre isso se discutirá no item 3.

\subsubsection{Correlação entre acusação e decisão}

A correlação entre a acusação e a sentença é corolário do princípio do contraditório e do princípio acusatório ${ }^{162}$. Como explica Badaró ${ }^{163}$, em um sistema inquisitório não há que se falar em necessidade de uma correlação entre a acusação e a sentença, pois a figura do juiz se confunde com a do acusador. Já no sistema acusatório, em que há separação clara entre estas duas funções, "o papel de acusar caberá exclusivamente ao Ministério Público, ou ao querelante nas ações penais de iniciativa privada, enquanto o juiz é quem julgará a imputação"164. De outro lado, o contraditório e o exercício da defesa ficam esvaziados se o acusado for surpreendido com uma imputação diferente daquela feita pelo órgão acusador. Se os fatos juridicamente qualificados imputados ao réu puderem ser modificados no decorrer do processo, o embate entre as partes é inútil.

\footnotetext{
${ }^{161}$ LOPES Jr. A. Processo penal. p. 147, com grifo e itálico no original.

${ }^{162}$ BADARÓ, G.H.R.I. Correlação entre acusação e sentença. p. 28.

${ }^{163}$ Idem. Ibidem p. 21 e seguintes.

${ }^{164}$ Idem. p 27.
} 
A necessária correlação entre imputação e decisão no âmbito do sistema acusatório é bastante explorada pela jurisprudência do Tribunal Constitucional espanhol, que assim conclui: "Por tanto, la vinculación entre la pretensión punitiva de las partes acusadoras y el fallo de la sentencia judicial, como contenido propio del principio acusatorio, implica que el órgano de enjuiciamiento debe dictar una resolución congruente con dicha pretensión, lo que responde a la necesidad no sólo de garantizar las posibilidades de contradicción y defensa, sino también de respetar la distribución de funciones entre los diferentes participantes en el proceso penal, y, más concretamente, entre el órgano de enjuiciamiento y el Ministerio Fiscal(...). De ese modo, el análisis del respeto a la garantía del deber de congruencia entre acusación y fallo por parte de una resolución judicial debe venir dado no sólo por la comprobación de que el condenado ha tenido la oportunidad de debatir los elementos de la acusación contradictoriamente, sino también por la comprobación de que el órgano de enjuiciamiento no ha comprometido su imparcialidad asumiendo funciones acusatorias que constitucionalmente no le corresponden."165

Quando da exposição dos argumentos pertinentes ao tema (capítulo 3) utilizaremos estas premissas para responder a duas indagações quanto à correlação entre acusação e sentença: 1-) Correlação entre acusação e sentença também significa, de forma geral, correlação entre pedido e decisão, especificamente quanto a decisões cautelares? 2-) $\mathrm{O}$ pedido de condenação já traz consigo (contém logicamente) o pedido de prisão preventiva?

\subsubsection{Prisão preventiva como medida cautelar}

A leitura constitucional indica que a privação da liberdade somente pode ocorrer obedecendo aos fins constitucionalmente previstos. Como foi visto no delineamento histórico do sistema acusatório, com o fortalecimento da ideia de separação entre acusador e julgador, resgata-se a ideia iluminista ${ }^{166}$ da presunção de inocência que começa a figurar, agora de forma assertiva, nas Constituição do pós-guerra. A ideia de presunção de inocência vem fortalecer a relevância do processo - o devido processo legal -

\footnotetext{
165 Tribunal Constitucional Espanhol Sentença 123/2005 disponível em http://hj.tribunalconstitucional.es/HJ/es-ES/Resolucion/Show/SENTENCIA/2005/123. Acessado em 20/7/2014.

${ }^{166}$ Sobre o Iluminismo e a presunção de inocência, ver MORAES, M.Z. Presunção de inocência. p. 69 e seguintes.
} 
para que o Estado exerça de forma legítima o ius puniendi (Goldschmidt). Já se lê no Código de Processo Penal tipo para a Ibero-América que os direitos fundamentais só poderão ser restringidos "quando for absolutamente indispensável para assegurar a apuração da verdade, o desenvolvimento do procedimento e a aplicação da lei" (art. 196). De acordo com Hassemer, sendo o Direito Processual Penal (com toda sua autonomia científica) que "elabora e organiza o cenário que o Direito Penal material necessita para efetivar-se", não faz sentido que ele mesmo crie punições que não digam respeito ao próprio processo. “O Direito Processual Penal intermedia entre o direito penal material e o Processo penal, ele 'serve' à realização do Direito Penal material." ${ }^{\text {"67 }}$. Como ensina Magalhães Gomes, como "por definição a medida cautelar constitui um instrumento a serviço do processo, a prisão imposta sob este título somente pode ser legitimada por finalidades previstas em lei e que, ademais, estejam de acordo com os valores constitucionais e sejam congruentes com a natureza do fim perseguido" ${ }^{\text {168 }}$. Estas são considerações fundamentais para que se garanta o nexo teórico e funcional entre pena, crime e processo ${ }^{169}$.

Decorre logicamente a ideia de vedação de antecipação da pena por qualquer motivo $^{170}$, e que as medidas pessoais (sendo a mais relevante a prisão preventiva, ou provisional na Espanha) antes da decisão final ${ }^{171}$ devem ter caráter cautelar, ligado essencialmente à segurança do processo ${ }^{172}$. A contrario sensu, adiantar a pena significa

\footnotetext{
${ }^{167}$ HASSEMER, W. op. cit. 172/173.

${ }^{168}$ GOMES F. , A.M. Presunção de inocência e prisão processual na Lei 12.403, de 2011. p. 442.

${ }^{169}$ FERRAJOLI, L. op. cit. p. 716.

${ }^{170}$ Exemplo típico do caráter de antecipação de pena da prisão preventiva em nossa legislação é o art. 30 da Lei 7.492/86, a respeito do qual diz Magalhães Gomes que são "inaceitáveis, diante da garantia examinada [presunção de inocência] as prisões processuais determinadas pela gravidade do delito ou, como ainda prevê a Lei 7.492, de 1986, em face da magnitude da lesão causada pelo crime." Presunção de inocência e prisão processual na lei 12.403, de 2011 p. 441.

${ }^{171}$ A ideia de "decisão final" pode não ter o mesmo significado técnico que a ela damos no Brasil. Em sistemas de justiça mais horizontalizados e colaborativos, como aqueles herdeiros do regime inglês - que valorizam o day in court sobre o direito de recurso - a decisão final pode ser considerada aquela de segunda instância, ou algumas vezes, até mesmo a de primeira instância. Cf. FRIESCHEISEN, Luiza Cristina Fonseca; GARCIA, Mônica Nicida; GUSMAN, Fábio. Execução provisória da pena: um contraponto à decisão do Supremo Tribunal Federal no Habeas Corpus n. 84.078. In CALABRICH, B.; FISCHER, D.; PELELLA, E. (coord.) Garantismo penal integral: questões penais e processuais, criminalidade moderna e a aplicação do modelo garantista no Brasil. p. 453-477.

172 "Es preciso insistir en el hecho, a veces olvidado por precipitadas opiniones que la prisión provisional es una medida cautelar de índole procesal, por lo que su finalidad y naturaleza deben ser las propias de este tipo de medidas, siempre en el espacio de las normas de procedimiento.(...) Admitir que uno auto de prisión pretenda fines distintos de los de índole procesal y asentarlo en razones de derecho penal, material, de penalidad $u$ otros que versen sobre el fondo del hecho investigado implica pervertir la finalidad y la 
subverter a ordem constitucional, ao anular a presunção de inocência e desativar o devido processo legal $^{173}$.

Também como corolário de um sistema autenticamente acusatório, temos que a prisão preventiva (a mais grave das medidas cautelares pessoais) antes da decisão final representa uma excepcionalidade que sempre deve estar regida pelo princípio da proporcionalidade (necessidade e adequação da medida adotada). Como coloca Magalhães Gomes, é absurdo e ilógico antecipar os efeitos do provimento final de forma mais gravosa do que a sentença pode trazer, principalmente quando é grande a probabilidade de ser substituída a pena privativa de liberdade por pena restritiva de direitos ou que o regime inicial fixado seja diferente do fechado. Assim, consagra-se o princípio da proporcionalidade $^{174}$.

Ainda de acordo com Magalhães Gomes, são fins legitimamente cautelares aqueles ligados à aplicação da lei penal e à investigação, sendo a prevenção especial estranha à cautela processual ${ }^{175}$.

Temos também como consequência destes novos traços cautelatórios da prisão processual a extinção gradual da preventiva automática ex lege, que tem uma natureza semelhante à prisão preventiva de ofício.

Essas características da prisão processual que expusemos são, sem dúvida, uma concepção trazida pelo movimento de superação dos sistemas inquisitórios que deixaram resquícios. Embora a legislação venha avançando para delimitar o campo da prisão preventiva apenas ao da garantia do processo em si, ainda há traços tormentosos do ponto de vista teórico ${ }^{176}$, como os conceitos de "ordem pública"" do crime". O primeiro, por sua extrema vagueza, abre grandes possibilidades de arbitrariedade e seletividade, além de colocar a prisão preventiva nas mãos do clamor

naturaleza de esta medida.” MACIÁ G., R.; ROIG A., M. El nuevo sistema de adopción de la medida cautelar de la prisión provisional. p. 76.

173 " $L$ 'esercizio del potere cautelare, nel modello accusatorio, e, in particulare nel nostro sistema (...), è strettamente assoggettato a limiti di legge" BERRI, G. op. cit. p. 6.

${ }^{174}$ GOMES F. , A.M. Presunção de inocência e prisão processual na Lei 12.403, de 2011. p. 443.

${ }^{175}$ Idem, ibidem. p. 443-444.

${ }^{176}$ Idem, ibidem. p. 441-442.

177 Conforme Magalhães Gomes, idem. p. 441-442, a Lei 12.403, de 2011, embora ainda conserve alguns resquícios inquisitórios, teve como mérito a delimitação do requisito da "garantia da ordem pública" através da fórmula "nos casos expressamente previstos, para evitar a prática de infrações penais". 
público de uma sociedade "hipersensibilizada ou desinformada" "178. O segundo traz à Justiça Criminal a difícil questão do encarceramento "pré-delito", dos exercícios de futurologia, que em realidade transformam os mecanismos cautelares em instrumentos de controle social diretos. Para vincular a natureza cautelar da prisão processual ao sistema democrático, lembra Maciá Gomes ${ }^{179}$ que foi no regime nazista que se introduziram no processo penal alemão elementos extraprocessuais vinculados à prisão preventiva, como a comoção social, a sensibilidade social criada pelo delito e o perigo de continuação no cometimento de crimes. $\mathrm{O}$ regime nazista facilitou a prisão preventiva principalmente com a instituição do "alarme social" (“Erörterung in der Offentlichkeit").

Essa persistência de características essencialmente inquisitórias da prisão preventiva a tornam em uma "sanção cautelar" 180 em um processo que pode ser qualificado como "fraude de etiqueta", sobre o qual trataremos à diante. Para reconhecer o real alcance de uma prisão decretada de ofício é indispensável que se tenha em mente estas funções “extracautelares" que a prisão preventiva desempenha em sistemas penais ainda bastante vinculados ao inquisitório, como é o brasileiro. O ideal cautelar da prisão processual próprio de um sistema acusatório em contraste com as possibilidades extracautelares em plena vigência no processo penal nacional deve servir de base para se pensar a regra que possibilita a prisão preventiva de ofício. O juiz tem a possibilidade de burlar o processo antecipando a pena sem a concorrência nem da defesa nem do próprio órgão acusador.

\subsubsection{Oralidade e simplificação dos ritos processuais}

No procedimento acusatório, o julgamento é público e oral ${ }^{181}$ i.e. o método de colheita de provas é bastante específico: o debate oral ${ }^{182}$. Vige, pois, o princípio da imediação entre as partes e o juízo. Nada que é aportado por uma das partes foge ao conhecimento da outra. Em oposição ao ideal inquisitório de trâmite processual (em que o processo é constituído de inúmeros atos de diversos escalões rigidamente documentados em "autos" que só fazem sentido se somados em um todo), a proposta acusatória é a concentração dos atos em um só acontecimento, o juízo oral, seguindo uma característica

\footnotetext{
${ }^{178}$ MACIÁ GOMEZ, R.; ROIG ALTOZANO, M. El nuevo sistema de adopción de la medida cautelar de la prisión provisional. p. 82 .

${ }^{179}$ Idem, ibidem. p. 76.

${ }^{180}$ AMBOS, K.; CHOUKR, F. H. A reforma do processo penal no Brasil e na América Latina. p. 161.

${ }^{181}$ ILLUMINATI, G. op. cit. p. 303.

${ }^{182}$ BERRI, G., op. cit. p. 5.
} 
da forma coordenada de administração da justiça ${ }^{183}$. Evidentemente, a interpretação da palavra falada determina uma forma de trabalho totalmente diferente da interpretação de transcrições. Exige-se o que Hassemer ${ }^{184}$ chama de "compreensão cênica". Diz o ex-juiz do Tribunal Constitucional da Alemanha que "[t] ambém o problema da percepção seletiva e da informação que existe no uso de qualquer linguagem, é muito mais grave no falar e no ouvir do que no escrever e ler. Pois o falar - principalmente na sala de audiência abrange a situação de fala integralmente: o juiz, os espectadores, os acusados, os amigos ouvintes, a distribuição da sala, as conexões de luz etc.; uma quantidade de informações em que somente uma pequena parte pode ser realmente percebida e transformada em totalidade, forma, imagem. Qualquer um que fala em tais situações produz estas informações, sem exceção, de acordo com o ambiente que o rodeia e dirige o seu discurso a ele, quer perceba ou não" ${ }^{\text {"185 }}$. Países filiados ao sistema romano-germânico já instituíram uma oralidade plena, proibindo que as partes leiam seus argumentos ou os apresentem escritos $^{186}$.

Ocorre que em um sistema acusatório a oralidade como método de produção de provas não é utilizada somente na cognição principal de um processo penal, ou seja, na condenação ou absolvição. O mesmo método deve ser utilizado para o juízo de cautelaridade $^{187}$.

A razão pela qual se menciona essa característica do sistema acusatório é o contraste com a forma escrita e burocrática como é tomada a decisão da prisão preventiva no Código de Processo Penal no Brasil, principalmente na nova famigerada “conversão" do flagrante trazida pelo inciso II do art. 310 do Código de Processo Penal, com redação determinada pela Lei 12.403 de $2011^{188}$, como veremos à frente.

\footnotetext{
${ }^{183}$ DAMAS̆KA, M. The faces... loc. 1219 of 6774.

${ }^{184}$ Op. cit. p. 176-179.

${ }^{185}$ HASSEMER, W. op. cit. p. 179.

${ }^{186}$ A Suécia e o Chile, por exemplo. Cf. TERRILL, R. J. World Criminal Justice systems. p. 258 e DUCE J., M.; RIEGO R. C. Proceso penal. p. 375 e seguintes.

${ }^{187}$ Como dizem DUCE J., M.; RIEGO R. C. Proceso penal. p. 126, "lo que sí significa la oralidad es que las principales cuestiones a resolver durante el desarrollo de la investigación tendrán que hacerse en audiencias. Así, por ejemplo, la formalización de la investigación, la discusión acerca de la prisión preventiva u otra medida cautelar personal, la solicitud de autorización judicial para realizar diligencias que puedan afectar derechos constitucionales, entre otras, sólo pueden producirse en audiencias."

188 Art. 310. Ao receber o auto de prisão em flagrante, o juiz deverá fundamentadamente: (...) II - converter a prisão em flagrante em preventiva, quando presentes os requisitos constantes do art. 312 deste Código, e se revelarem inadequadas ou insuficientes as medidas cautelares diversas da prisão.
} 


\subsubsection{O sistema acusatório "puro" e o sistema do common law}

Muito se tem discutido sobre a pretensa pureza do sistema acusatório, conforme já foi mencionado no item anterior. A suposta intangibilidade de um "acusatório puro", associado ao sistema adversary, já serviu de argumento para se conservar toda a sorte de elementos tipicamente inquisitórios na legislação processual penal brasileira ${ }^{189}$. Acusatório puro, ou adversarial, seria, segundo alguns, o sistema inglês e seus herdeiros (como o estadunidense, canadense, irlandês, australiano e neozelandês) e que não seria parâmetro para a nossa legislação, uma vez que o acusatório "puro" ou adversarial não vigeria no Brasil ${ }^{190}$.

Fixemos alguns conceitos aos quais nos filiamos com objetivo de algum padrão técnico de linguagem que se possa seguir. O termo adversarial pode ser entendido de forma equívoca como um procedimento ou um sistema. Como procedimento ou método, adversarial consiste simplesmente em uma audiência em que duas partes opostas disputam $^{191}$, uma dinâmica de colheita de provas. Na segunda acepção, adversarial consiste em um sistema de justiça penal no qual partes ativas ${ }^{192}$ contendem com respeito a um pleito perante um julgador independente, em um processo com todas as garantias individuais do devido processo legal, como a publicidade, a presunção de inocência etc. ${ }^{193}$.

\footnotetext{
${ }^{189}$ Lembremos do art. 156 (com redação dada pela Lei no 11.690 , de 2008) e da primeira parte do art. 385 (com redação mantida desde 1941), bastiões da inquisição em nosso ordenamento processual penal

${ }^{190}$ Essa posição foi esposada pelo Ministro Sepúlveda Pertence durante as discussões do julgamento da ADI 1.570 de 2004 mencionada a seguir.

${ }^{191}$ Definição do Black's Law Dictionary p. 62.

192 Aqui se coloca a interessante definição de parte do juiz catarinense Alexandre Morais da Rosa. Estudando a estrutura do processo penal sob o prisma da teoria dos jogos, Morais da Rosa coloca a parte como um jogador (i.e. "agentes racionais em busca da realização da estratégia pretendida, ou seja, a vitória. Não se confundem com o julgadro, cuja função é coordenar e decidir o jogo, garantindo o cumprimento de suas regras." Guia compacto do processo penal conforme a teoria dos jogos. p. 39.

${ }^{193}$ Idem, Ibidem. O processo adversarial é entendido como aquele que depende da iniciativa das partes, conforme PANZAVOLTA, M. Reforms... p. 578. Para o pesquisador, acusatório seria todo um sistema de justiça penal cujas características seriam a oralidade, a publicidade etc. Adversarial seria a dinâmica da colheita de provas i.e. um procedimento dentro do sistema acusatório. Transcreve-se excerto de Panzavolta: "This Article takes the position that an accusatorial system of criminal procedure allows a judge to make decisions based only on evidence collected in oral form (the principle of orality), in his presence (the principle of immediacy), in a public trial containing adversarial dynamics. In other words, an accusatorial system clearly separates the investigation and trial stages. In an inquisitorial system, the judge's decisions are based on evidence, regardless of whether it was collected in oral form." op. cit. p. 582. Para Damaška, "[ $\mathrm{t}]$ he adversarial mode of proceeding takes its shape from a contest or a dispute: it unfolds as an agagement of two adversaries before a relatively passive decision maker whose principal duty is to reach a verdict. The nonadversarial mode is structured as an official inquiry". DAMAŠKA, M. The Faces... Loc. 170 of 6774
} 
O dicionário jurídico Black ${ }^{194}$ vai adiante dizendo que, nesta segunda acepção, adversary pode ser utilizado como sinônimo da palavra - mais usada nos sistemas continentais acusatório. Do quanto foi dito, não é equivocado dizer que sistema adversarial seria sinônimo de sistema acusatório ${ }^{195}$. Também não seria equivocado dizer que em um sistema acusatório (ou adversarial), o método de colheita de provas é o adversarial.

O sistema anglo-americano de justiça penal - para o qual mais comumente se utiliza a classificação adversarial - desenvolveu-se em contraste com a tradição inquisitória. A referência que o Iluminismo utilizou para conceber um novo sistema de justiça penal que poderia servir de antítese teórica, e oportunamente substituir o inquisitório pré-revolucionário, era o modelo inglês, "o autêntico herdeiro do processo acusatório romano" $"$. Os estadunidenses classificam seu próprio sistema de "antiinquisitório", balizando a interpretação das normas processuais por oposição ao inquisitório $^{197}$. O sistema continental serviu para a Grã-Bretanha e para os Estados Unidos apenas como um contraexemplo ligado a "confissões produzidas por meio da coerção,

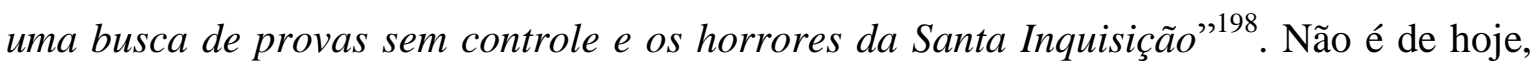
portanto, que o sistema de justiça anglo-saxão estranha o processo penal continental. Em uma interessante e reveladora notícia jornalística, publicada em 14 de abril de 1895 no jornal New York Times ${ }^{199}$, essa disparidade vem à tona. Diz a nota que "a consequência [da confusão de funções de acusar e julgar e da inversão do princípio da presunção de inocência] é que para um inglês ou um americano, o ato de reportar um julgamento

\footnotetext{
${ }^{194}$ O dicionário Black, uma das mais prestigiadas publicações jurídicas do Direito estadunidense - inclusive já citado em decisões da Suprema Corte -, embora não seja propriamente uma fonte da ciência do Direito, é citado aqui para ilustrar a mameira pela qual os jurístadas da common Law veem o instituto.

${ }^{195}$ Scarance Fernandes, por exemplo, menciona que o sistema que sempre vigorou na Inglaterra é o sistema acusatório. FERNANDES, A.S. Teoria Geral... p. 78. É claro que o sistema do common law admite institutos estranhos aos sistemas continentais, como a discricionariedade do Ministério Público.

${ }^{196}$ ILLUMINATI, G. Op. cit. p. 304. Para se demonstrar a identidade entre um sistema acusatório "puro" e o adversary, menciona-se que Gimeno Sendra chama de "acusatório puro" aquele instituído na "Alta República" Romana cujas notas essenciais eram a acusação realizada por pessoa distinta da do juiz, publicidade de todo o procedimento, oralidade, paridade absoluta entre os direitos do acusador e do réu, aportação de provas a cargo das partes e liberdade pessoal do acusado. GIMENO S., J.V. El derecho... p. 267. De acordo com Jacinto Coutinho, “[o] processo inglês, assim, dentro do common law, nasce como um autêntico processo de partes, diverso daquele antes existente. Na essência, o contraditório é pleno; e o juiz estatal está em posição passiva, sempre longe da colheita da prova.” op. cit. p. 36.

${ }^{197}$ Crawford vs. Washington 541 U.S. 36 (2004). Enquanto os acadêmicos continentais classificam seu próprio sistema como um meio caminho entre o inquisitório (pré-revolucionário) e o acusatório (reformado), os profissionais do direito anglo-americanos não titubeiam em classificar o sistema continental como inquisitoriais. DAMAŠKA, M. The Faces... Loc. 5352 of 6774.
}

${ }_{198}^{19}$ DAMAŠKA, M. Aspectos...p. 1.

199 Disponível em http://query.nytimes.com/mem/archivefree/pdf?res=9A06E6DB133DE433A25757C1A9629C94649ED7CF. Acessado em 22 de junho de 2014 
francês, ainda mais uma "audiência" francesa, parece perfeitamente escandaloso". O mesmo artigo também usa a palavra "bárbaro" para classificar o sistema continental. Parecendo comprovar o assombro do jornalista, o primeiro julgamento do caso Dreyfus aconteceria no final de 1894.

Nos Estados Unidos da América, a tradição de um due process se aprimorou, como foi dito antes, e este conceito inspirou a moralização do processo penal no mundo ocidental. O último dos grandes passos históricos da jurisprudência americana em direção à Ilustração foi dado na época do mandato do Chief Justice Earl Warren (19531969). São desse período as decisões clássicas que marcaram a aplicação da teoria da "preferred-position", segundo a qual os direitos individuais se sobrepõem aos direitos de propriedade (marcado pelo caso Bell v. Maryland de $1964^{200}$ ). Já dizia o Chief Justice que quando a geração de 1980 recebesse o Bill of Rights, o documento não teria o mesmo significado $^{201}$. Documento clássico que toca o assunto aqui em questão é a decisão do caso Miranda v. Arizona de $1966^{202}$, talvez a mais relevante decisão judicial da história do processo penal. Neste caso, entre outras disposições, ficou assentado que o momento desde o qual começa o direito a um advogado é a prisão do acusado. A maioria da Suprema Corte, então, seguindo o voto do Chief Justice, albergou a ideia de que os direitos do devido processo garantidos pela $5^{\mathrm{a}}$ Emenda da Constituição Americana devem valer não somente na corte - especificamente no julgamento da causa - mas também servem para proteger a pessoa em todos os casos em que sua liberdade de ação é reduzida. Ainda antes do simbólico caso Miranda, o caso Pointer v. Texas de $1965^{203}$ reforçou o direito do

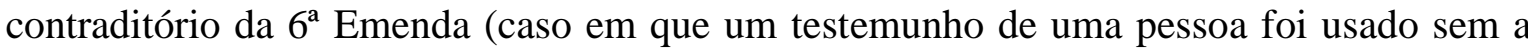
possibilidade do cross-examination). Mais recentemente, os avanços da corte dos anos 60 foram relativizados (movimento jurisprudencial que, ironicamente, coincidiu com mudanças contrárias dos países continentais) ${ }^{204}$, mas suas concepções ainda servem de base para se entender o processo penal hoje.

\footnotetext{
${ }^{200}$ SCHWARTZ, B. The unpublished opinions of the Warren Court. p.143 e seguintes

${ }^{201}$ Idem. Ibidem. p. 17.

$202 \quad$ http://supreme.justia.com/cases/federal/us/384/436/case.html acessado em $1^{\text {o }}$ de agosto de 2014. Neste caso o próprio Chief Justice Warren, falando pela maioria, classificou o sistema americano várias vezes de acusatório (accusatory).

203 http://supreme.justia.com/cases/federal/us/380/400/case.html acessado em $1^{\circ}$ de agosto de 2014

${ }^{204}$ DAMAŠKA, M. Aspectos... p. 2.
} 
Com isso, evidentemente, não se quer dizer que o sistema americano é o padrão de moralidade para o processo penal, mas alguns conceitos lá cunhados ou desenvolvidos como o próprio due process e o sistema acusatório autêntico, serviram para o aprimoramento de sistemas de justiça pelo mundo. Críticas sobram para aquele sistema, sendo uma das mais contundentes o chamado "vanishing trials", situação em que apenas uma mínima parte dos casos judiciais penais é realmente julgado, sendo a maioria resolvido com as negociações como o guilty plea $^{205}$. Esta crítica específica ao regime estadunidense e inglês por parte de doutrinadores europeus continentais e latinoamericanos, embora tenha o mérito de denunciar a "pena sem processo", deve ser vista sob o ponto de vista da coerência. Interessante notar que, tradicionalmente, o sistema angloamericano admite que o imputado possa desistir de seu direito a um processo por meio do plea of guilty. Isso choca os operadores do direito do sistema continental, que acreditam que todos os casos devem passar pelo processo (basta lembrar as críticas que foram opostas à transação penal da Lei dos Juizados Especiais taxando-a de "pena sem processo"). Interessante notar que não choca tanto o operador continental a prisão preventiva (que tem fortíssimo componente de aplicação antecipada da pena com o fenômeno da fraude de etiqueta, que será vista adiante) de ofício, sem contraditório, sem as partes, sem processo. De resto, a tendência de transação indica uma flexibilização mesmo em regimes como o italiano $^{206}$ e no brasileiro ${ }^{207}$. O modelo de justiça penal do common law serviu como paradigma de reforma de muitos países tradicionalmente ligados ao civil law, como o Chile (que há 25 anos seguia o modelo inquisitório à risca), várias províncias argentinas, a Costa Rica e até para os símbolos do sistema inquisitório como a Espanha e a Itália ${ }^{208}$.

Outra das críticas é o distanciamento que a doutrina europeia continental insiste em manter entre processo civil e penal. Illuminati, por exemplo, sustenta que o sistema acusatório italiano se afasta do sistema adversarial anglo-saxão, que, segundo ele,

\footnotetext{
${ }^{205}$ Plea significa "[t] he defendant's formal answer to a criminal charge. The defendant says: "guilty," "not guilty," or "nolo contendere" (no contest)." HALL, D. E. Criminal law and procedure. p. 500. Os casos que terminam com a assunção de culpa sem julgamento de provas chegam a 96\% nos EUA cf. SAMAHA, J. op. cit. p. $442 / 443$.

${ }^{206}$ Por exemplo, a applicazione della pena su richiesta delle parti (art. 444 do CPP de 88) e o procedimento per decreto (art. 459 do CPP de 88 ) que consiste em um procedimento em que o juiz aplica uma pena sem um julgamento oral e sem a presença do acusado.

${ }^{207}$ Por exemplo, o art 76 da Lei 9.099/95 que, embora não tenha a mesma natureza do plea bargain, significa, em última análise, o fim prematuro do processo.

${ }^{208}$ Panzavolta ensina que o Código de 1988 afasta o processo penal italiano do sistema inquisitivo e o coloca no caminha do sistema adversarial. op. cit. p.578.
} 
sofre influência do processo civil, em que as partes se confrontam e o juiz não é mais do que um árbitro. O sistema continental, diz ele, concebe o processo penal "como um instrumento para o Estado implementar suas políticas criminais preferidas" ${ }^{209}$. Com base em Goldschmidt, estabelecemos a diferença entre a jurisdição civil e penal, que em nada obsta um sistema adversarial (ou acusatório). Lembremos, também, que há muito, tanto no mundo da common law quanto da civil law a acusação é levada a cabo por um órgão do Estado. A discussão, então, se desloca. Não se trata simplesmente de o Estado fazer valer sua política de segurança pública, mas sim que o juiz seja a mais forte (ou a mais relevante, ou, até mesmo, a única) voz do Estado.

De acordo com estas observações, concluímos que, embora não se possa vislumbrar a aplicação de um "acusatório puro", já que se trata apenas de um tipo ideal, pode-se vislumbrar um sistema "acusatório autêntico", equivalente a um sistema adversarial. Com "autêntico" nos referimos a um sistema livre dos resquícios perniciosos da inquisição e de acordo com um Estado Democrático de Direito.

\subsection{Modelo inquisitório}

\subsubsection{Delineamento histórico}

Como foi visto no item introdutório do capítulo, a conformação do processo penal está intrinsecamente ligada à concepção de Estado e como este se legitima ao administrar justiça. Nesse passo, temos que, historicamente, o sistema inquisitório está instalado no pilar da tradição do crime como infração, como desobediência à norma estatal $^{210}$ (em contraposição à já vista tradição do crime como um conflito, que se desenvolveu principalmente nas civilizações ateniense, romana republicana e feudal, e deu as bases para o procedimento criminal do common law). O inquisitório tem seu desenvolvimento ligado à "estatização" ou "publicização" do delito, que deixa de ser uma lesão à esfera de direitos de alguém para ser um agravo a toda a sociedade, uma questão de Estado, uma área de atuação em que o soberano poderia demonstrar seu poder de imperium. O texto clássico do historiador da Inquisição Henry Charles Lea lembra uma

\footnotetext{
${ }^{209}$ ILLUMINATI, G. op. cit. p. 316.

${ }^{210}$ BINDER, A.M. op. cit. p. 266 e seguintes; FOUCAULT, M. A verdade e as formas jurídicas. p. 67.
} 
passagem ilustrativa desta definição de delito, quando, em plena Idade Média, uma criança acidentalmente matou outra em uma brincadeira com uma flecha. Seus pais foram proibidos de se reconciliarem gratuitamente, sem a presença do Estado ${ }^{211}$. É neste sentido que expressões controversas que pululam na legislação atual, como "ordem pública" serão entendidas neste trabalho, e o juiz, representante (ou, na formulação clássica de Pontes de Miranda, "presentante") maior do Estado no âmbito do processo, será o ator principal.

O modelo inquisitório de justiça penal tem suas raízes remotas na civilização antiga hindu, hebraica e egípcia ${ }^{212}$, mas encontra sua forma histórica mais modelar com a publicização que ocorre na passagem da República para o Império romano no final do primeiro século antes de Cristo ${ }^{213}$, já mencionada. Com o abandono das antigas tradições da República, e com a transferência de poder do senado para o imperador, o processo penal romano ganha contornos marcadamente públicos. O magistrado (paraefectus urbi e praefectus vigilum que substituíram os pretores da época da República), representante do imperador, detinha amplos poderes para acusar e julgar. Não mais havia partes como conhecemos hoje, já que quando o Estado “instruía proceso espontáneamente, sin excitación ajena, para ver si se había cometido un delito, y cómo, y para señalar la pena". "Aquí no había partes en el sentido jurídico, sino que quienes se hallaban frente á frente en este procedimiento eran, de un lado, la comunidad por medio de su representante, y de otro lado el acusado" ${ }^{214}$. Temos aí o processo como affaire de deux $x^{215}$, que marca toda a evolução histórica do processo em geral e a prisão preventiva de ofício, em particular.

Foi nesse período em que "el procedimiento de oficio, por iniciativa del proprio magistrado, resucitó de entre los escombros producidos por el derrumbe del sistema acusatorio; con él aparecieron las características siempre ligadas a su realización: la escritura como forma de proceder para documentar los actos procesales, el

\footnotetext{
${ }^{211}$ LEA, H.C. A History of the Inquisition of the Middle Ages. Loc. 672 of 11831.

${ }^{212}$ GRINOVER, A.P. Liberdades públicas. p. 27-28, ALMEIDA J., J.M. O processo criminal brasileiro. p. 16 e seguintes.

${ }^{213}$ Ressalva-se, aqui, a opinião de SAAD, M. e MALAN, D. R. op. cit. para quem "a origem histórica do modelo inquisitivo de processo penal localiza-se no processo canônico, onde os poderes inquisitivos do juiz na condução do processo atingiram o ápice."

${ }^{214}$ MOMMSEN, T. El derecho penal romano. T. I. p. 336.

${ }^{215}$ Expressão de Mirjan Damaška.
} 
secreto de los actos, la recurribilidad de las decisiones por ante aquel que había delegado el poder de administrar justicia, en una suerte de devolución de ese poder"216.

$\mathrm{Na}$ época do Principado (24 AC a 284 AD), as fórmulas arbitrais de procedimento que deram origem ao sistema acusatório ${ }^{217}$ conviveram com aquelas em que o magistrado atuava de ofício (cognitio) em favor dos interesses da comunidade, mas, a partir da estruturação do império, a soberania passa gradativamente da cidadania ao imperador $^{218} \mathrm{e}$, ainda que a forma acusatória permanecesse, o procedimento de ofício foi se tornando mais comum à medida que o imperador foi concentrando mais poder. Forma-se o que se chamou de cognitio extra ordinem, consistente em um procedimento de ofício, por iniciativa do magistrado ${ }^{219}$, que, para além de administrar justiça, impõe o imperium da fonte da jurisdição. A própria concepção da cognitio extra ordinem tinha em seu bojo a ideia de cognição "como método de enjuiciamiento penal que presuponía la omnipotencia procesal al reunir, en una única mano, por lo menos dos de las funciones principales del procedimiento, la requirente y la decisoria" e o resultado foi "el triunfo de la inquisición publica, secreta y escrita que ganó considerable terreno frente al debate oral y, por ende, la pérdida de posiciones del acusado, ahora perseguido de oficio, interrogado y hasta sometido al encarcelamiento preventivo" ${ }^{220}$. Os processos populares mostraram-se mais dispendiosos e menos eficazes. A cognição extraordinária, antes utilizada principalmente para crimes políticos (abuso de poder e corrupção) foi estendida a todos os outros ${ }^{221}$, e a prisão provisória serviu como instrumento na demonstração do poder imperial contra a impunidade $^{222}$.

Após a queda do Império Romano do ocidente no século V A.D., a pulverização do poder na Europa fez declinar o direito romano processual penal tardio, que ressurgirá depois como grande modelo nas nascentes monarquias nacionais da Baixa Idade Média $^{223}$ e com a consolidação do poder da Igreja Católica. Quando o clero começa a ver o delito como uma infração religiosa, o sistema de persecução penal da época do Império

\footnotetext{
${ }^{216}$ MAIER, J.B. op. cit. p. 284 e seguintes.

${ }^{217}$ BINDER, A.M. op. cit. 267.

${ }^{218}$ MAIER, J. B. op. cit. 284.

${ }^{219}$ Idem p. 287.

${ }^{220}$ Idem. Ibidem.

${ }^{221}$ MOUSOURAKIS, G. A legal history of Rome. p. 77.

${ }^{222}$ MORAES, M.Z. Presunção de inocência no processo penal brasileiro. p. 20.

${ }^{223}$ BINDER, A.M. op. cit. 267.
} 
Romano é aproveitado através do Direito Canônico ${ }^{224}$. Os interesses que têm de ser protegidos pelo poder religioso (questões de alma) não se podem compatibilizar com sistemas privados ou acusatórios de justiça criminal, e ao lado da concentração de poder vem a ideia católica da ubiquidade ${ }^{225}$. Assim, o direito canônico recebeu de bom grado a herança burocrática do Império e a aperfeiçoou de acordo com seus próprios fins. Quando o delito ofende diretamente ao deus cristão em seu objetivo de salvar as almas dos homens, quaisquer meios de persecução e de prova eram bem-vindos. Até mesmo o bem do acusado era o objetivo da autoridade que acusava e julgava ao mesmo tempo. Por isso, o réu haveria de cooperar ${ }^{226}$, pois, se não o fizesse, merecia a morte por traição a cristo, como propunha o papa Inocêncio III, o "papa legista do século XIII"227, que reclamava seu poder absoluto acima de todos os reis da Europa. A igreja medieval, que via o crime como uma infração de lesa divindade, tratava o procedimento penal como um bem para o próprio réu que, através do sofrimento e da culpa, poderia se arrepender e salvar sua alma ${ }^{228}$.

O expurgo da heresia tornou-se o trabalho dos prelados e, após 1233, quando a instituição da Inquisição foi fundada por Gregório $\mathrm{IX}^{229}$, a velha cognitio extra ordinaria fez-se ordinária e passaria a ser a regra na persecução das infrações.

A ressurreição do direito processual penal imperial pelo direito canônico (recepção do direito romano-canônico ${ }^{230}$ ) importou em um processo de racionalização (no sentido escolástico do termo) do procedimento frente à dita irracionalidade dos duelos, disputas privadas e dos juízos de deus próprios do direito germânico antigo aplicado na Alta Idade Média. A exceção a esse ressurgimento na Europa ocidental foi a Inglaterra, que, por motivos particulares ${ }^{231}$, ficou imune à instituição da inquisição religiosa.

Foi na "santa inquisição" que a salus publica suprema lex est encontrou sua expressão máxima "por la necesidad de reprimir todo comportamiento punible, para lo que se concede al Estado el poder de perseguir penalmente y se dispone um

\footnotetext{
${ }^{224}$ MAIER, J. B. op. cit. 287.

${ }^{225}$ A própria palavra "católico" tem sua origem remota, de acordo com o Diccionario de la Real Academia

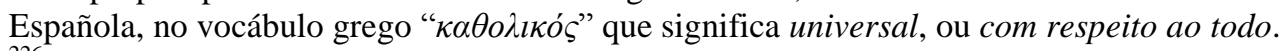

${ }^{226}$ ILLUMINATI, G. op. cit. p. 301-302.

227 Consta que teria sido Professor de Direito em Paris e em Bolonha, de acordo com João Mendes de Almeida Junior. Op. cit. p. 79.

${ }^{228}$ ILLUMINATI, G. op. cit. p. 302.

${ }^{229}$ RUSSELL, B. A history of western philosophy. p. 448.

${ }^{230}$ MAIER, J.B. op. cit. 289.

${ }^{231}$ BINDER, A. op. cit. p. 276 e seguintes.
} 
procedimiento adecuado para investigar la verdad y lograr certeza en la reconstrución histórica de aquello que, se afirmaba, había sucedido"232.

A inquisição em Portugal, que depois legou seu direito ao Brasil, desenvolveu-se junto à centralização governamental levada a cabo pelo religioso Dom João III. A inquisição portuguesa recebeu a sanção papal em 1536 - quase 60 anos após a espanhola, que legou seu direito a todas as suas colônias americanas. O irmão mais novo de D. João III, o cardeal Dom Henrique, foi nomeado inquisidor geral e cumulou o cargo quando se tornou rei após o desaparecimento de Dom Sebastião em $1578^{233}$. Em Portugal, os tribunais eclesiásticos exerciam a jurisdição em uma gama ampla de delitos como sacrilégio, perjúrio, blasfêmia, bruxaria, adultério, incesto, sodomia, simonia e a manutenção de casas de jogos ${ }^{234}$.

O sistema inquisitório eclesiástico foi paulatinamente seduzindo o poder secular $^{235}$, que abandonou as nascentes instituições acusatórias anteriores e passou a aplicar os novos procedimentos para os crimes que pouco tinham a ver com a heresia, situação que permaneceria quase inalterada até que o Iluminismo lhe atacasse as bases no século XVIII. Com a instituição da inquisição controlada pelo poder real na Baixa Idade Média, para a persecução de crimes comuns além daqueles dos costumes, “o processo penal, novamente, passa a ser entendido e utilizado como mais uma forma (...) para a defesa dos domínios reais e católicos contra seus inimigos (hereges ou não)"236. É por esta via que sentimos os ecos da inquisição até hoje no processo penal ${ }^{237}$. O Direito Romano Imperial punitivo foi restaurado na formação do Estado moderno - enquanto se abandonava totalmente a participação popular no processo ${ }^{238}$ - uma vez que as estruturas políticas a que respondiam

\footnotetext{
${ }^{232}$ MAIER, J.B. op. cit. 85-86.

${ }^{233}$ DISNEY, A. R. A history of Portugal and the Portuguese Empire. p. 235.

${ }^{234}$ Idem. Ibidem.

${ }^{235}$ Situação notada principalmente na Espanha, que viu sua monarquia nacional nascer da união da rainha de Castela com o príncipe - depois rei - de Aragão: os "reis católicos" Isabel e Fernando. A rainha logrou de Roma a fundação da inquisição em Castela em 1478 em bula na qual já se encontrava a prerrogativa real de nomeação do inquisidor geral. O frei dominicano Tomás de Torquemada foi a escolha da rainha. Em Aragão, o rei Fernando reinstituiu a antiga inquisição papal, agora a seu mando, fazendo com que Torquemada acumulasse a inquisição geral dos dois reinos. LEA, H.C. A history of the inquisition of Spain. v. I. p. 157 e seguintes.

${ }^{236}$ MORAES, M.Z. op. cit. 51.

${ }^{237}$ MAIER, J.B. op. cit. 286.

238 "As the apparatus of justice grew increasingly bureaucratic, medieval popular participation was swept away, so that only sporadically were some of its vestiges in evidence" DAMAŠKA, M. The faces... loc 3867 of 6774 .
} 
eram análogas. Neste âmbito, a constituição do delito como infração desempenha um papel primordial, como foi dito no início.

Como visto, foi apenas após o Iluminismo e, mais precisamente, após a Revolução Francesa, que os sistemas processuais penais da Europa continental sofreram uma inflexão, com reformas que foram abrandando as forças inquisitórias e restauraram algumas das características da Roma republicana. O Code d'instruction criminelle, promulgado por Napoleão em novembro de 1808, separou a fase inquisitória, de investigação, de uma fase em que seria instituído um procedimento acusatório, influenciando boa parte dos códigos processuais penais (até mesmo o brasileiro de 1941, em que se instituiu as "duas fases" do procedimento, uma inquisitória - inquérito - e outra supostamente acusatória) e representando um grande passo legislativo contra um sistema oficialista de persecução penal. É bem verdade, como veremos a seguir, que em algumas jurisdições esta separação interfases não é bem visível ${ }^{239}$, tendo a fase investigatória proeminência em todo o processo, contaminando a suposta fase acusatória. Como será visto na oportunidade de se mencionar o sistema dito "misto", o modelo gestado pelo novo imperador arrebatou pouco terreno do sistema inquisitório. Os sistemas que se formaram sob a égide napoleônica (principalmente a codificazione del 1865, o Strafprozessordnung de 1877 e a Ley de Enjuiciamiento Criminal de 1882) se apartaram pouco do ideal inquisitório.

$\mathrm{O}$ século $\mathrm{XX}$, com seus extremos políticos ligados em geral ao fortalecimento do Estado frente ao indivíduo, principalmente no Brasil e nas nações que professam um sistema de justiça mais próximo ao nosso (fascismo na Itália, nazismo na Alemanha, franquismo na Espanha ${ }^{240}$, salazarismo em Portugal e as ondas ditatoriais da América Latina tanto nos anos 30 e 40 quanto nos anos 60 e 70), foi campo bastante

\footnotetext{
${ }^{239}$ Tema caro aos italianos, como se verá a seguir.

${ }^{240}$ Os vários matizes fascistas do século XX beberam na fonte filosófica do cristianismo reacionário e receberam deste apoio incondicional, como observa o historiador alemão do cristianismo Karlheinz DESCHNER, God and the fascists. Esta é a linha lógica que liga as antigas tradições de administração da justiça aos fascistas contrailuministas que a era dos extremos levou ao poder. A tradição da inquisição subjazeu por longo período após a Idade Média. A inquisição espanhola enforcou (após uma "fogueira simbólica") o último herege em 1826, quase meio século depois da queda da Bastilha, e os métodos da inquisição continuaram na Espanha franquista "all the longer, since 30 percent of the staff of the director general had been trained by experts of Himmler, with whom Franco had made a 'Police Agreement', in 1940, that is, by German Gestapo members whom the general continued to employ as a 'brain trust' even after the war. His popularity among the people is supported by the fact that after the war he had to spend over 50 percent of his GDP on army and police to keep himself in power. Social condition were organized accordingly". Idem. p. 84.
} 
receptivo aos ideais inquisitórios que haviam sido enfraquecidos no século $\mathrm{XIX}^{241}$. O pensamento fascista encontrava na Baixa Idade Média uma fonte inesgotável do instrumental que poderia ser usado contra os avanços do iluminismo. As ideologias fascistas penetram com muito mais facilidade que os avanços acusatórios, como demonstra o fato de que, em 25 anos, o Código italiano de 1988 sofreu mais ataques da Corte costituzionale della Repubblica que o Código fascista de 1930 em toda sua história ${ }^{242}$.

Nesta configuração promíscua entre investigação e processo, o inquisitivo segue sendo o bastião cuja derrota é visada pelos reformistas atuais na Itália, na Espanha, na quase totalidade a América Hispânica e no Brasil.

A partir da concepção de crime como infração, cujo combate envolvia menos aquele que havia sofrido o dano e mais o poder estatal, concluímos o traço principal deste modelo de persecução penal: a iniciativa do juiz para o procedimento. Ao lado da concentração de poder nas mãos de um só ator do processo, temos a utilização de todos os meios para extirpar a infração, tendo a prisão provisória papel de relevo no processo, junto à tortura e a burocratização do procedimento. "De hecho la íntima relación histórica entre investigación inquisitiva, secreto del sumario y prisión provisional configura la marca de fábrica más clara del principio inquisitivo" ${ }^{243}$.

\subsubsection{O papel do juiz no sistema inquisitório}

Conforme a configuração histórica que delineamos no item anterior, temos que o juiz em um modelo inquisitório de processo penal é a personificação da justiça, assim como seu ancestral direto, o inquisidor da Idade Média, era o defensor de deus na Terra. Conforme coloca Jacinto Nelson Coutinho, "o controle do processo penal pelos clérigos exclui, por conveniência, um órgão acusador: o actus trium personarum já não se sustenta. Ao inquisidor cabe o mister de acusar e julgar, transformando-se o imputado em mero objeto de verificação, razão pela qual a noção de parte não tem nenhum sentido. A superioridade do juiz, à evidência, é nítida (mas lógica, na estrutura do

\footnotetext{
${ }^{241}$ Basta lembrar que um dos primeiros processualistas do Brasil, aluno da primeira turma da Academia de São Paulo, e que chegou a Presidente do Conselho de Ministros entre 1870 e 1871, José Antônio Pimenta Bueno, o Marquês de São Vicente, sustentava que o "juiz não deve ser senão, árbitro imparcial, e não parte". Cf. MARQUES, J.F. Elementos de direito processual penal. V.I. p. 48.

${ }^{242}$ ILLUMINATI, G. op. cit. p. 308.

${ }^{243}$ MACIÁ G., R.; ROIG A., M. El nuevo sistema de adopción de la medida cautelar de la prisión provisional. p. 77.
} 
sistema), até porque o desencadeamento e o impulso processual é atribuição sua, o que pode ser evidenciado, entre outras coisas, a partir do fato de fixar tanto o thema probandum quanto o thema decidendum"244.

A ideia de limites ao poder do juiz, conquista gradual do Iluminismo e dos movimentos revolucionários, é estranha ao sistema inquisitório clássico. Dizia o manual dos inquisidores que: "Es peculiar y nobilísimo privilegio del tribunal de inquisicion que no estén los jueces obligados á seguir las reglas forenses, de suerte que la omisión de los requisitos que en derecho se requieren no hace nulo el proceso, con tal que no falten las cosas esenciales para determinar la causa...,"245.

O inquisidor tem a responsabilidade da supressão da heresia ${ }^{246}$, tanto quanto o juiz inquisidor tem a responsabilidade pela "ordem pública" e pela punição e aniquilação do delito criminal que ameaça a sociedade e o poder estatal. No papel ativo, o juiz tem um poder-dever de atuar para fazer valer a punição devida ao delito e poderia, como observa Zanoide, citando Franco Cordero, ser considerado cúmplice se não o fizer. A omissão do juiz era vista como uma indolência ou preguiça, e quando não houvesse punição adequada por parte do magistrado, o próprio deus apareceria para a vingança ("Deus ipse ad vindictam exsurgit") ${ }^{247}$.

Por isso, o processo penal inquisitivo importa na junção, na mesma pessoa, do acusador e do julgador, assim como sua inspiração teórica, o velho processo da inquisição católica. O juiz é mais que um árbitro (ou o ator imparcial que pondera os argumentos e contra-argumentos trazidos pelas partes contrapostas), e a garantia dos direitos constitucionais fundamentais do acusado é apenas uma preocupação secundária. $\mathrm{O}$ juiz do sistema inquisitório representa um interesse: a efetivação do poder estatal, assim

\footnotetext{
${ }^{244}$ COUTINHO, J.N.M. O papel do novo juiz no processo penal. p. 23.

245 MARCHENA, Don J. (trad.). Manual de inquisidores: para uso de las inquisiciones de España y Portugal ó Compendio de la Obra titulada Directorio de Inquisidores, de Nicolao Eymerico. p. 2.

${ }^{246}$ Para uma descrição precisa e completa do juiz inquisidor, ver a clássica obra de LEA, A History.. v. I. loc. 6477 of 11831. "If his sacred mission was accomplished, it mattered little what methods were used." "The inquisitor, with endless iteration, was empowered and instructed to proceed summarily, to disregard forms, to permit no impediments arising from judicial rules or the wrangling of advocates, to shorten the proceedings as much as possible by depriving the accused of the ordinary facilities of defence, and by rejecting all appeals and dilatory exceptions. The validity of the result was not to be vitiated by the omission at any stage of the trial of the forms which had been devised to prevent injustice and subject the judge to responsibility."

${ }^{247}$ Op. cit. p. 53-54.
} 
como seu antecessor representava o poder eclesiástico, real ou imperial ${ }^{248}$. E este poder não intencionava simplesmente uma resolução de conflito nascido do delito criminal, mas a implementação de uma política pública. Em suma, o juiz do sistema inquisitório, mais do que simplesmente prescindir de uma parte acusadora, não deve depender das partes para decidir, pois responde por valores superiores. Pelo contrário, a atuação (da defesa) ou omissão (da acusação) podem ser perniciosas.

O juiz inquisidor, em cuja mão se concentram os poderes processuais, tem a concepção da "luta contra o inimigo" e, desta forma, de enfraquecimento da presunção de inocência e dos direitos processuais em geral do imputado ${ }^{249}$. Tendo a justiça em seu poder, ele deve apurar e investigar tanto quanto possível para que sua decisão tenha mais qualidade. O papel típico do juiz no sistema inquisitório é o de um "buscador independiente de la verdad" ${ }^{250}$, "presuntamente no contaminado por intereses extraños" 251 . Temos então, o "decisionismo" superando o "cognocitivismo", ou seja, as técnicas de prevenção e defesa social determinam a subjetividade da decisão judicial que acaba por ser embasada em "valoraciones, diagnósticos y sospechas subjetivas antes que en pruebas del hecho",252.

Da estruturação estatal de repressão do ilícito e da profissionalização de seus atores, seguiria natural que o julgador pudesse agir de ofício (ou simplesmente com colaboração) para formar melhor seu próprio juízo e para verificar se estariam presentes os requisitos do exercício de seu próprio direito de apenar. "De este modo se desarrolla el principio inquisitivo en el procedimiento romano ante el magistrado, así como en el proceso canónico, y en Francia y Alemania después de la invasión del derecho canónico-

\footnotetext{
${ }^{248}$ MAIER, J.B. op. cit. 294-295.

${ }^{249}$ MORAES, M.Z. op. cit. 51-52.

${ }^{250}$ DAMAŠKA, M. Aspectos... p. 8, em interessante frase cuja ambiguidade pode ser intencional.

${ }^{251}$ STRUENSEE, Eberhard; MAIER, Julio B. J. Introdución. p. 20.

${ }^{252}$ FERRAJOLI, L. op.cit. p. 43. "A la atenuación o disolución de la estricta legalidad se unen así las de la estricta jurisdiccionalidad: es decir, una acentuación, hasta los límites de la arbitrariedad, del poder de etiquetamiento y de inquisición del juez, que viene a configurarse según la ocasión como confesor, psicoanalista o terapeuta social, en todos los casos desvinculado de criterios rígidos y ciertos de calificación penal. Y el juicio penal, al igual que el ético o el estético, degenera en juicio .sin verdad»: no motivado por juicios de hecho, esto es, por aserciones verificables o refutables, sino por juicios de valor, no verificables ni refutables porque por su naturaleza no son verdaderos ni falsos; no basado en procedimientos cognoscitivos al menos tendencialmente y, por ello, expuestos a controles objetivos y racionales, sino en decisiones potestativas; no realizado mediante reglas del juego -como la carga de la prueba y el derecho de defensaque garanticen la «verdad procesal», sino confiado a la sabiduría de los jueces y a la verdad sustancial» que ellos poseen."
} 
italiano". À configuração inquisitiva "aborrece toda limitación que la ley pondría al libre arbitrio del Juez con respecto a los presupuestos de su intervención o a la recogida o al aprovechamiento del material procesal, y, por tanto, no puede nacer ningún defecto en estas actuaciones a consecuencia de la inactividad de una parte o de la vinculación legal del Juez,"253.

Vemos, então, uma configuração diferente - talvez oposta - àquela que descortinamos na introdução deste trabalho. A estrutura processual inquisitiva, embora não aniquile por completo, menoscaba os direitos individuais, preteridos em favor da busca pela verdade real e a implementação de uma certa política de Estado (Damaška). Não é por outro motivo que Ferrajoli chama o sistema inquisitivo genericamente de anti-garantista ${ }^{254}$. O juiz é o protagonista do processo e, em posição dominante, conduz a fase da busca de $\operatorname{provas}^{255}$, tendo a acusação apenas como um auxiliar ou colaborador ${ }^{256}$. Cumula as funções de investigar a verdade e julgar ${ }^{257}$, ou seja, um trabalho essencialmente solitário.

A imparcialidade de um juiz que acusa, prende, inquire e julga é um atributo apenas teórico, sem aplicação objetiva. Em um sistema de justiça tipicamente de implementação de política, a imparcialidade dá lugar ao monopólio do conhecimento do direito e a capacidade de fazer justiça, de tomar a decisão mais correta e justa ${ }^{258}$. Exemplo do papel onipresente e onipotente do juiz no sistema inquisitivo e que permaneceu como concepção adotada no Brasil até não muito tempo atrás está plasmado no documentário "Justiça" 259 . Mostra-se de forma cabal como o processo penal no Brasil se configura em um affaire à deux. Nas palavras de Canuto ${ }^{260}$ : “[na instrução criminal] exsurge o diálogo inquisitivo entre o Estado, que aponta determinado fato, como ato ilícito penal, o suspeito, como seu autor, para que o assim indiciado defenda, por enquanto, o interesse próprio em instrução criminal preliminar - de livrar-se dos efeitos processuais penais da indiciação." E, mais adiante, “a plenitude do contraditório na instrução criminal definitiva há de permanecer inviolável, como indeclinável garantia de defesa, mas sem lhe

\footnotetext{
${ }^{253}$ GOLDSCHMIDT, J. op. cit. p. 68-69.

${ }^{254}$ FERRAJOLI, L. op. cit. p. 41.

${ }^{255}$ BERRI, G. op. cit. p. 5.

${ }^{256}$ Como acontecia na Itália pré Código de 1988, cf. PANZAVOLTA, M. op.cit. p.579.

${ }^{257}$ STRUENSEE, Eberhard; MAIER, Julio B. J. op. cit. p. 22.

${ }^{258}$ DAMAŠKK, M. The faces... loc 3508 of 6774.

259 Direção e produção de Maria Augusta Ramos. Documentário. Brasil: produção independente, 2004. Disponível em: http://www.youtube.com/watch?v=_GrBKbZ6aPc. Acessado em 5 set. 2014.

${ }^{260}$ ALMEIDA, J.C.M. op. cit. p. XXIV.
} 
corresponder poder dispositivo sobre o pleno exercício do poder-dever inquisitivo do juiz, derivado, que este é, do caráter impessoal, geral, do interesse punitivo e, por consequência, do interesse processual penal".

Nos sistemas processuais penais ditos "mistos", esta visão de juiz segue com certa força, em razão da importância que se dá aos elementos colhidos na fase préprocessual que minimizam a ideia de contenda da fase processual ${ }^{261}$. De acordo com Damaška, evitar que o juiz tenha acesso aos autos pré-processuais é uma das reformas mais "subversivas" que minariam o sistema inquisitório ${ }^{262}$.

Como se verá no item a seguir, a decisão sobre a prisão processual reveste-se de uma importância que transcende o próprio processo penal. O juiz fala pela ordem pública, e fala só, no caso de decisões de ofício. Como diz o juiz espanhol Maciá Gomez, "desde una óptica inquisitiva el Juez de Instrucción, dueño y señor absoluto de la investigación, sí que está legítimamente amparado para interesar la prisión provisional. Desde una óptica del principio acusatório, no lo está,263.

\subsubsection{A importância da custódia processual e o processo como início}

\section{de aplicação da pena}

Estabelecemos que o juiz inquisidor está comprometido com a busca da verdade e da decisão mais justa. Na história da justiça penal, o mito da "verdade real" e sua incessante busca comprometeu sobremaneira o corpo do acusado. "O corpo supliciado se insere em primeiro lugar no cerimonial judiciário que deve trazer à luz a verdade do crime 264 . Para isso, a tortura é um meio lícito e útil para se chegar ao desfecho do que realmente aconteceu, como subsídio importante para a decisão mais justa possível ${ }^{265}$.

\footnotetext{
${ }^{261}$ Como já foi dito, este é um dos mais importantes aspectos da reforma na Itália.

262 DAMĂ̌KKA, M. Aspectos... p. 8.

${ }^{263}$ MACIÁ GOMEZ, R.; ROIG ALTOZANO, M. op. cit. 77.

${ }^{264}$ FOUCAULT, M. Vigiar e punir. p. 32.

${ }^{265}$ Mais um exemplo da perenidade das instituições inquisitórias, a tortura segue medrando no Brasil. É necessário lembrar que o Subcomitê de Prevenção da Tortura e outros Tratamentos ou Penas Cruéis, Desumanos ou Degradantes da Organização das Nações Unidas, no Relatório sobre a visita que fez ao Brasil em 2011, concluiu que "a despeito da vedação legal às provas obtidas por meio ilícito, tem-se notícia de que confissões - incluídas aquelas obtidas mediantes tortura - têm sido utilizadas em procedimentos judiciais" e que "os juízes raramente faziam perguntas aos detentos sobre o tratamento que recebiam durante a investigação", apesar das recomendações para fazê-las (p. 7). A evidência do uso frequente da tortura também ficou estampada na carta que a Human Rights Watch enviou ao Congresso Nacional brasileiro em 28 de julho de 2014 demonstrando "concerns regarding the ongoing use of torture and the ill-treatment of 
Ao lado da violação da integridade corporal - uma vez que a acusação e a responsabilidade por fazer justiça vêm de uma só pessoa - o julgador -, o sistema inquisitório inverte a ideia da presunção de inocência, substituindo-a pela presunção de culpabilidade do imputado desde a formalização da acusação ${ }^{266}$. A prisão processual é regra, e a liberdade, exceção. À maneira dos Tribunais antigos da inquisição, a garantia que o acusado esteja por todo tempo à disposição da justiça reveste-se de fundamental importância e qualquer suspeita de fuga significa a prisão até que o Tribunal esteja pronto para o julgamento ${ }^{267}$. A presunção de culpabilidade, como já ocorreu na era imperial de Roma e na santa inquisição, leva o próprio processo a servir como um início de expiação de pena. Estar enredado em um processo penal, em seus caminhos extremamente sofisticados e complicados - figurar como réu - já é o início da aplicação da pena ${ }^{268}$. É natural, então, que se estabeleça um regime de "coerção necessária",269, no qual direito processual e direito material se confundem e medidas análogas (ou mais graves) à pena final podem ser, desde logo, levadas a cabo. A ideia de prisão preventiva como tendo uma natureza de direito material é essencial ao sistema inquisitivo ${ }^{270}$.

Por outro lado, a prisão processual em um regime inquisitório também tem o papel de defesa da sociedade contra o criminoso (ordem pública ${ }^{271}$ ), e o juiz torna-se

detainees by police and prison authorities in Brazil". Disponível em
http://www.hrw.org/sites/default/files/related_material/20140728_Brazil_Torture EN.pdf. Acessado em 16 de abril de 2014.

${ }^{266}$ BERRI, G. op. cit. p. 5.

${ }^{267}$ LEA, H.C. op. cit. loc. 6582 of 11831.

${ }^{268} \mathrm{O}$ vocabulário jurídico guarda esta concepção quando se diz que alguém, ao cometer um ilícito, "estaria sujeito a um processo penal" ou "pode sofrer um processo penal”. De acordo com Zanoide, "essa conclusão ressurte evidente pela lógica estrutural daquele sistema. Nele, a imputação já nasce comprometida com um único resultado possível, a condenação. Tal ocorre porque, estando o magistrado imperial incumbido das funções de investigar, acusar e julgar, somente acusaria alguém se já guardasse em seu íntimo a certeza de que ele cometera o delito. Caso isso ainda não lhe estivesse maduro no "intimo", seguramente investigaria mais, não oferecendo pífia acusação que o desacreditasse. Logo oferecida a acusação, pela natural certeza na culpa do julgador/acusador/investigador, era necessário que o réu (invariavelmente culpado) esperasse sua decisão (invariavelmente condenatória) preso. Era, por este viés, natural que se aceitasse para a prisão provisória uma finalidade de antecipação da pena." MORAES, M.Z. op. cit. p. 23.

${ }^{269}$ DUCE J., M.; RIEGO R., C. Proceso penal. p. 247.

${ }^{270}$ MACIÁ GOMEZ, R.; ROIG ALTOZANO, M. op. cit. 77.

${ }^{271}$ A antecipação da punição está estritamente ligada à garantia de ordem pública. "[antecipação da punição] é o que ocorre, no sistema brasileiro, com a prisão preventiva determinada para a "garantia da ordem pública ou da ordem econômica" (art. 312, primeira parte, do CPP, mantida pela Lei 12.403), na medida em que esta fórmula excepcionalmente ampla e aberta, ao conferir amplo poder discricionário aos juízes, acaba por possibilitar a ruptura dos padrões de unidade e hierarquia inerentes aos princípios da constitucionalidade, da legalidade e da certeza jurídica. De fato, em matéria de prisão processual, à ideia de ordem pública relacionam-se todas aquelas finalidades de encarceramento provisório que não se ajustam às exigências de caráter cautelar propriamente ditas, mas constituem formas de privação de liberdade pessoal adotadas como medidas de defesa social; fala-se, então, em exemplaridade, no sentido de imediata reação 
responsável por sua aplicação. Nas palavras do juiz Alexandre Morais da Rosa, "parcela majoritária da magistratura entende que a prisão cautelar torna as cidades seguras, o agente deve permanecer preso antecipadamente, quem sabe cumprir toda a pena, até que se confirme a decisão. Pensam conforme a matriz inquisitória" ${ }^{\text {272 }}$. O sistema inquisitório admite a custódia preventiva com intensidade como instrumento de defesa da coletividade $^{273}$, valorizando-a contra os direitos individuais, tudo para se aplacar a sanha da luta contra a impunidade ${ }^{274}$, por um lado, e legitimar o sistema de justiça, por outro. A prisão processual é um auto-de-fé. Vemos exemplo desta concepção na exposição de motivos do vigente Código de Processo Penal, de 1941. Diz o idealizador do Código, Francisco Campos, que " a decretação da prisão preventiva, que, em certos casos, deixa de ser uma faculdade, para ser um dever imposto ao juiz, adquire a suficiente elasticidade para tornar-se medida plenamente assecuratória da efetivação da justiça penal" ${ }^{, 275}$. Voltamos a ver o poder-dever do juiz mencionado no item anterior.

Estes traços inquisitórios da prisão processual persistem em nossos dias, em confronto direto com a ideia de cautelaridade da prisão provisória, abordada no capítulo do acusatório.

\subsubsection{A noção de expediente escrito, burocrático, hierarquizado e} secreto como características do sistema inquisitório

Como visto, com a concentração de poder e o desenvolvimento do sistema inquisitório no início da era imperial da Roma antiga, o processo penal passou a

ao delito, que teria como efeito satisfazer o sentimento de justiça da sociedade abalada pelo crime; ou, ainda, em prevenção especial, assim entendida a necessidade de evitar novos crimes, pois a primeira infração pode revelar que o acusado é acentuadamente propenso a práticas delituosas etc." (GOMES F. A.M. Presunção de inocência e prisão processual na lei 12.403, de 2011. p. 441-442).

${ }^{272}$ ROSA, A.M. op. cit. p. 163.

${ }^{273}$ BERRI, G. op. cit. p.5.

274 MORAES, M.Z. op. cit. 24-25.

${ }^{275}$ E mais adiante: “A prisão preventiva, por sua vez, desprende-se dos limites estreitos até agora traçados à sua admissibilidade. Pressuposta a existência de suficientes indícios para a imputação da autoria do crime, a prisão preventiva poderá ser decretada toda vez que o reclame o interesse da ordem pública, ou da instrução criminal ou da efetiva aplicação da lei penal. Tratando-se de crime a que seja cominada pena de reclusão por tempo, no máximo, igual ou superior a dez anos, a decretação da prisão preventiva será obrigatória, dispensando outro requisito além da prova indiciária contra o acusado. A duração da prisão provisória continua a ser condicionada, até o encerramento da instrução criminal, à efetividade dos atos processuais dentro dos respectivos prazos; mas estes são razoavelmente dilatados". 
ser secreto e escrito ${ }^{276}$, já que não se prestava mais à resolução de um conflito, mas a uma afirmação da autoridade hierárquica estatal.

A burocracia e o expediente minuciosamente documentado em folhas cuidadosamente numeradas e rubricadas, com copiosas certidões rigorosamente fabricadas, é uma herança direta do processo canônico da Idade Média ${ }^{277}$. São, de fato, as “numerosas y mecanismos procesales que entorpecen inútilmente la búsqueda de la verdad. Normas de este tipo llegaron a su máximo desarrollo en los viejos regímenes inquisitivos que inventaran "una multitud de formalidades", "dilaciones", "intrigas y laberintos" cuyo solo efecto fue hacer "complicada la simple máquina de los juicios públicos",278.

Charles Lea lembra que os inquisidores "eram instruídos a preservar cuidadosamente todos os procedimentos, desde as primeiras intimações até a sentença final em todos os casos, junto a listas de todos os que fizeram o juramento imposto a cada um para defesa da fé e persecução da heresia". De acordo com Lea, havia uma reiteração das ordens de documentação, além da duplicação de todos os documentos, sendo que uma cópia deveria ser guardada em um cofre. A inquisição precisava disso para controlar melhor o terror que infligia aos homens ${ }^{279}$.

Conforme ensina Foucault de forma elucidativa sobre o sistema inquisitório, "por seu lado, o magistrado tinha o direito de receber denúncias anônimas, de esconder ao acusado a natureza da causa, de interrogá-lo de maneira capciosa, de usar insinuações. Ele constituía, sozinho e com pleno poder, uma verdade com a qual investia o acusado; e essa verdade, os juízes a recebiam pronta, sob a forma de peças e de relatórios escritos; para eles, esses documentos sozinhos comprovavam; só encontravam o acusado uma vez para interrogá-lo antes de dar a sentença. A forma secreta e escrita do processo confere com o princípio de que em matéria criminal o estabelecimento da verdade era para o soberano e seus juízes um direito absoluto e um poder exclusivo. (...) A informação

\footnotetext{
${ }^{276}$ ILLUMINATI. G., op. cit. p. 300. No mesmo sentido: BERRI, G. op. cit. p. 5.

277 A compilação de normas canônicas chamadas de Decreto de Graciano, no século XII, já trazia a expressão “Accusatorum persona ninquam recipiantur sine scripto”. Cf. ALMEIDA Jr., J.M. op. cit. p. 72. ${ }^{278}$ FERRAJOLI, L. op. cit. p. 61.

${ }^{279}$ LEA, H.C. op. cit. loc. 6156/6161 of 11831 (tradução livre de trecho).
} 
penal escrita, secreta, submetida, para construir suas provas, a regras rigorosas, é uma máquina que pode produzir a verdade na ausência do acusado",280.

A burocracia e a escrituração formam o que Binder chama de "ideologia do trâmite", que é tanto um produto como um sustentáculo de uma cultura jurídica inquisitória muito difícil de romper. Adverte o Professor argentino que a crítica não significa simplesmente uma "guerra ao papel", mas uma guerra à primazia dos registros sobre o sentido dos atos processuais ${ }^{281}$. A estrutura inquisitória legou ao processo penal atual a ideia segundo a qual o trâmite - um ato após outro, todos documentados de forma meticulosa - se torna aspecto primordial do processo e, até mesmo da investigação (vemos o mesmo esmero burocrático na formação dos autos do inquérito policial). De acordo com Binder, o "escrituralismo" e sua tradução corpórea - os autos - são a "forma específica da tradição inquisitorial" 282 . A cultura inquisitória repele o princípio da oralidade e da simplificação dos ritos - com a forma de debate público entre as partes - porque com estes o juiz deixa de agir solitariamente como foi descrito no capítulo anterior.

Damaška traça a relação entre a forma burocrática hierárquica e a necessidade dos autos, ou seja, da pasta contendo a comprovação de atos processuais em ordem rigorosamente cronológica ${ }^{283}$, já que o sistema inquisitório tem como uma de suas características a hierarquia. Os atos processuais devem ser preservados na forma de documento para uma reavaliação da causa em grau superior, "devolvendo" (expressão que tem sua origem da devolução da própria jurisdição dos delegados - juízes inferiores - a quem de fato a detinha: o rei ${ }^{284}$ ) a questão aos órgãos superiores.

O segredo é outra das heranças da velha inquisição. O papa Bonifácio VIII (cujo pontificado durou de 1294 a 1303 e que, de acordo com Dante, se encontra no

\footnotetext{
${ }^{280}$ FOUCAULT, M. Vigiar e punir. p. 32-34.

281 "Si se concurre a la vida cotidiana de la gran mayoría de las oficinas de la justicia penal, se va a encontrar que la realidad omnipresente es ese cúmulo de papeles: todo gira alrededor de el, no sólo el trabajo administrativo, lo que sería más comprensible, sino todo el trabajo, ya sea de investigación o de litigio. Presentar papeles, expedir notas, dejar constancia, agregar escritos, etc., en una rutina de movimiento continuo, donde lo determinante no es hacia dónde ni para qué sino simplemente que la rueda siga girando, que no se detenga, porque si lo hace, las deficiencias serían tan notorias e muchas de las acciones tan ridículas causarían pudor." BINDER. A.M. op. cit. p. 80 e seguintes.

${ }^{282}$ Idem. p. 84.

283 DAMAŠKA, M. The faces... Loc 1077 of 6774.

${ }^{284}$ No sistema antigo, o titular da jurisdição não era o juiz - simples delegado - mas o rei. Em um tempo que a soberania não pertencia ao povo, o rei era o administrador da justiça e os juízes deviam-lhe subordinação hierárquica. Cf. MAIER, J.B. Derecho procesal penal. p. 259 e seguintes.
} 
oitavo círculo do inferno ${ }^{285}$ ) instituiu através do Cânon Statuta quœdam o processo sumário e secreto, inclusive com ameaça de excomunhão a quem quebrasse o sigilo processual $^{286}$. Charles Lea sustenta que o terrível procedimento da Inquisição poderia ter sido impedido simplesmente se os julgamentos fossem públicos.

Como consequências destas características do processo burocrático, escrito e hierarquizado, verificam-se a demora nos julgamentos finais e a dependência que o sistema deposita na prisão processual ${ }^{287}$. A decretação de ofício da prisão preventiva no atual estágio do ordenamento jurídico brasileiro se insere neste contexto, como se verá mais à frente. Trata-se de uma decisão sem a presença das partes, sem o método oral do acusatório moderno e que é tomada, de certa maneira, secretamente, de forma que as partes só ficam sabendo da decisão depois de já consumada. O juiz toma a decisão solitariamente, embasado em elementos escritos, sem receber o acusado. A situação torna-se mais marcadamente inquisitória com a chamada "conversão" da prisão em flagrante para a prisão preventiva instituída pelo inciso II do art. 310 do Código de Processo Penal, com redação determinada pela Lei 12.403 de $2011^{288}$, sobre a qual também se tratará mais adiante.

\subsection{Modelo misto}

Já foi dito que o movimento de reforma do sistema inquisitório teve sua gênese com o Iluminismo e na sua expressão política, a Revolução Francesa. No início da era revolucionária (entre 1789 e 1792), a França viu alguns institutos marcadamente

\footnotetext{
${ }^{285}$ ALIGHIERI, D. A Divina Comédia: inferno. C. XIX, 52, p. 135.

"Ed El gridò: "Se' tu già costí ritto, se' tu già costí ritto, Bonifazio?

Di parecchi anni mi menti lo scritto."

286 ALMEIDA, J.M. op.cit. p. 76.

${ }^{287}$ No Brasil, principalmente após o julgamento do Habeas Corpus no 84.078 em fevereiro de 2010 pelo Supremo Tribunal Federal, firmou-se o entendimento de que a pena somente poderia ser executada depois do trânsito em julgado da decisão condenatória, dando-se plena vigência ao inciso LVII do art. $5^{\circ}$ da Constituição Federal. Isso significa passar a causa pela primeira instância, pela segunda instância em grau recursal, pelo Superior Tribunal de Justiça e pelo Supremo Tribunal Federal. A cada passagem nos Tribunais, vários recursos são possíveis, como a própria apelação (que permite a revisão de direito e de fato), os recursos em sentido estrito, os agravos contra as decisões monocráticas, os embargos infringentes e declaratórios, além das ações autônomas de impugnação, de cujas decisões também cabem recursos.

288 Art. 310. Ao receber o auto de prisão em flagrante, o juiz deverá fundamentadamente: (...) II - converter a prisão em flagrante em preventiva, quando presentes os requisitos constantes do art. 312 deste Código, e se revelarem inadequadas ou insuficientes as medidas cautelares diversas da prisão.
} 
acusatórios vicejarem, como o Tribunal do Júri, o direito de defesa, a cross-examination, a publicidade e a eleição de juízes e promotores. O movimento pós-revolucionário se esforçou em instituir alguns elementos de uma justiça que resolvia conflitos (em oposição à justiça que implementa política pública) no processo penal inquisitório, no que se chamou teoria do amálgama ${ }^{289}$. Conforme foi colocado quando do estudo do modelo acusatório, a primeira lei processual penal da Revolução (1791) compreendeu a superação dos princípios inquisitórios do Ancien Régime. O sentido foi o resgate da cultura romana republicana, do direito inglês e, em parte, do direito germânico, como visto acima.

Com o recrudescimento político do terror na reação termidoriana, os avanços de 1791 perderam terreno com o Código de 1795 que vigeu até 1808. O Code d'instruction criminelle de 1808 - chamado "napoleônico" por ter sido promulgado no esteio das codificações do novo imperador - veio instituir um novo sistema, restabelecendo algumas das antigas práticas inquisitórias e introduzindo características acusatórias ${ }^{290}$. Estabeleceu duas fases no procedimento: a primeira, inquisitorial, em que o juge d'instruction presidia um procedimento escrito e secreto assumindo para si a investigação. A segunda fase era oral e permitia às partes a introdução de provas. Esta configuração passou a ser conhecida como modelo misto ou acusatório formal.

A presunção de inocência quedou-se enfraquecida, como já era no regime anterior. Illuminati menciona que os elementos acusatórios do Code d'instruction eram "mais aparentes que reais", já que os atos praticados durante a fase inquisitorial seguiam relevantes para a decisão na "fase acusatória",291. Outros, como Jacinto Coutinho, sustentam que o processo napoleônico, em realidade, não significa mais que um retrocesso às formas inquisitórias pré-revolucionárias ${ }^{292}$.

O Código de 1808 influenciou vários países europeus continentais, que o tomaram como um "modelo de referência"293 para reformar seus próprios códigos. O sistema misto que se desenvolveu na Itália no esteio na codificação napoleônica e após a unificação significou uma conciliação possível e original entre inquisitivo e acusatório, entre a proteção dos direitos individuais e o interesse público, mas lhe faltou coerência,

\footnotetext{
${ }^{289}$ DAMA ̌́KA, M. The faces... Loc 3889 of 6774 e seguintes.

${ }^{290}$ ILLUMINATI, G. op. cit. 304.

${ }^{291}$ Idem. Ibidem. p. 305.

${ }^{292}$ COUTINHO, J.N.M. op. cit. p. 38

${ }^{293}$ ILLUMINATI. G. op. cit. p. 305.
} 
como observa Illuminati ${ }^{294}$. A lei processual penal alemã de 1877 também seguiu o modelo francês de 1808 e já foi classificada de "semiacusatória", "inquisitiva com acessórios acusatórios" ou "processo inquisitivo de forma acusatória" (Goldschmidt) ${ }^{295}$. O Código brasileiro de 1941 foi também construído sob influência do modelo das duas fases.

Conforme foi mencionado no capítulo 1, coloca-se aqui novamente a discussão sobre a "pureza dos sistemas". Se não há no mundo real nenhum sistema puramente inquisitório ou puramente acusatório, todos os sistemas processuais penais que vigoram ou vigoraram no mundo seriam mistos? A resposta é negativa. O sistema misto (ou acusatório formal) não será visto neste trabalho como uma teoria middle-ranged, ou tampouco um caminho natural em que o inquisitório se tornaria paulatinamente um autêntico acusatório. Embora possa ter sido idealizado como um amálgama dos dois modelos antagônicos, o sistema misto tem uma configuração específica, que consiste teoricamente na separação das duas fases procedimentais. Distinguimos, portanto, o modelo misto de um sistema "misturado", “desordenado" (expressão usada por Binder para classificar o sistema argentino ${ }^{296}$ ), ou "confuso" (expressão usada por Panzavolta para qualificar o sistema italiano após a contrarreforma de $1992^{297}$ ) que se adéqua, em realidade, à classificação inquisitória ${ }^{298}$.

O cerne da questão do sistema misto, como observa Illuminati, é a influência de uma fase na outra, ou seja, como os elementos colhidos na primeira fase importarão na segunda ${ }^{299}$. As fórmulas liberais que intencionavam isolar a fase do juízo oral não foram tão bem-sucedidas em razão do fato de que o clamor pelo interesse público e pela verdade real (típicos do inquisitorialismo) tentava inflar a importância da fase inquisitiva do processo. À medida que decisões judiciais e inovações legislativas tornavam a presença ativa do defensor obrigatória na fase oral (como seria óbvio), mais importância era colocada na investigação, que deveria exaurir todas as questões controversas antes da fase acusatória (vista como uma ameaça à realização da justiça). Conforme ensina Damaška, "at trial, information from the investigation continued to exert a strong influence

\footnotetext{
${ }^{294}$ Idem. Ibidem. p. 306.

${ }^{295}$ GOLDSCHMIDT, J. op. cit. p. 70.

${ }^{296}$ Idem. Ibidem. p. 25.

297 Op. cit. p. 600.

298 Neste sentido há que se concordar com os acadêmicos anglo-americanos que não titubeiam em classificar o sistema continental como inquisitorial. Damaška, M. The Faces... Loc. 5352 of 6774.

${ }^{299}$ O ponto também é explorado por GIMENO S., J.V. El derecho... p. 267.
} 
on decision making, notwithstanding protests of academic commentators". Mesmo nessa fase de investigação se poderia admitir certa participação da defesa, mas apenas nos casos em que isso não frustraria a investigação. Após, os resultados da investigação eram transmitidos para o promotor público, que apresentava a acusação que condicionaria os fatos relevantes a serem decididos. Mas o julgamento na "fase acusatória" era feito apenas para simular uma contenda, com a participação ativa do juiz ${ }^{300}$. A ideia seria que o juiz se preparasse meticulosamente para a fase acusatória para que não fosse surpreendido. $\mathrm{O}$ resultado foi que a fase de investigação preliminar passou a ser "o procedimento crucial de todo o processo" 301 .

Illuminati sustenta que o sistema italiano pré-88 não passa de um "remake" do modelo inquisitório francês de que deriva. O que ocorre é que a fase "acusatória" tem menos importância que a fase inquisitiva, tratando-se tão somente de uma recapitulação do dossiê investigativo, "a futile play put on to provide the semblance of an accusatorial process, at worst" ${ }^{\prime 302}$. A fase "acusatória" passa a ser apenas uma auditoria e um referendo do que já foi colhido de forma inquisitória. No caso da Itália pré-88 temos, nos dizeres de Panzavolta, um sistema essencialmente inquisitório, disposto, teoricamente, em duas fases distintas ${ }^{303}$.

Jacinto Nelson Coutinho observa que "o dito sistema misto, reformado ou napoleônico é a conjugação dos outros dois, mas não tem um princípio unificador próprio, sendo certo que ou é essencialmente inquisitório (como o nosso), com algo (características secundárias) proveniente do sistema acusatório, ou é essencialmente acusatório, com alguns elementos característicos (novamente secundários) recolhidos do sistema inquisitório ${ }^{\text {304 }}$. Esta ideia confere com a exposição que fizemos acima a respeito da definição de sistema. Sem um (ou alguns) princípios que unificam todas as normas, não há sistema, por definição. Entretanto, a ideia de Coutinho, Illuminati e Panzavolta e a que nos filiamos neste trabalho é a de que tanto na Itália pré-88 quanto no Brasil atual temos,

\footnotetext{
${ }^{300}$ DAMAŠKA, M. The faces... Loc 3906 of 6774 e seguintes.

${ }^{301}$ DAMAŠKA, M. The faces... Loc 3936 of 6774 e seguintes.

${ }^{302}$ ILLUMINATI, G. op. cit. p. 307.

303 op. cit. p. 589.

${ }^{304}$ COUTINHO, J.N.M. op. cit. p. 17. "Ademais, talvez fosse o caso de, singelamente, recordar que a "mistura" há de ser vista com cautela em qualquer ramo do direito processual, a começar pelo direito processual civil, como anotou Liebman.” p. 39.
} 
sim, um princípio unificador: o princípio inquisitivo (ainda que este não seja, como será visto adiante, o princípio disposto na Constituição Federal de 1988).

Embora tenha sido retirada do juiz a iniciativa da ação penal, sua face de Janus seguia na figura do juiz instrutor, central na investigação e, portanto, em todo o processo penal. Em meio a estes sistemas mistos, a prisão processual segue com uma marca essencialmente inquisitória, ou seja, de clara antecipação da pena e com requisitos “extracautelares" (razões alheias à proteção do próprio processo), como a "ordem pública", a "gravidade da acusação", "a prevenção de crimes futuros a serem praticados pelo acusado" e a prisão processual automática em certas circunstâncias. Isso ocorre mesmo com um rompante legal "cautelar", em um fenômeno que Duce e Riego chamam de "fraude de etiqueta" 305 . Nesta deturpação das funções cautelares, a prisão processual tornase um (talvez o principal $^{306}$ ) instrumento de controle social na mão do Estado-juiz.

Esta argumentação é reforçada pelo fato de que no sistema angloamericano a fase de investigação é inquisitória. No interessante caso McNeil v. Wisconsin julgado pela Suprema Corte dos Estados Unidos em $1991^{307}$, Justice Stevens acusou a maioria da corte de favorecer um sistema inquisitório nos Estados Unidos. A resposta de Justice Scalia seguiu no sentido de que não havia nada de mágico nas palavras "adversarial" e "inquisitório". Explicou o atual decano daquela corte que o que torna um sistema adversarial em vez de inquisitório é simplesmente a presença de um juiz que não conduz a investigação fatual e jurídica (como faz um juiz inquisidor), mas apenas decide com base nos argumentos contrários e favoráveis. Diz ainda que a fase de investigação tinha que ser inquisitória. Seria, então, o sistema de justiça americano "misto"? Dificilmente.

Diante desta dificuldade que os sistemas processuais penais da Europa continental têm de superar a herança inquisitória, os juristas anglo-americanos compartem

\footnotetext{
${ }^{305}$ DUCE J., M.; RIEGO R., C. Proceso penal. p. 246. "La razón de esta casi permanente polémica acerca de la coerción procesal reside, en nuestra opinión, precisamente en la similitud antes indicada, esto es, la posibilidad de ampliar la coerción procesal implica siempre la forma más rápida y menos exigente de extender la respuesta punitiva, sobre la base de lo que podemos calificar como un fraude de etiquetas, esto es: apliquemos más penas de manera más rápida y menos exigente, pero con otro nombre."

${ }^{306}$ Lembremos das estatísticas entre presos provisórios e com condenação definitiva.

${ }^{307}$ McNeil v. Wisconsin, 501 U.S. 171, 189 (1991) in SKLANSKY, D.A. Anti-inquisitorialim. p. 1636.
} 
da visão segundo a qual os sistemas continentais são simplesmente variações inquisitórias (ou não adversariais) ${ }^{308}$.

A redemocratização do pós-guerra no século XX na Itália e na Alemanha (sabemos que a portuguesa e a espanhola foram tardias) foi mudando o panorama processual com a instituição de medidas mais acusatórias ${ }^{309}$, conforme se observou no capítulo sobre o sistema acusatório.

\footnotetext{
${ }^{308}$ De acordo com DAMAŠKA, M. Aspectos... p. 2. No mesmo sentido COUTINHO, J.N.M. op. cit. p. 17. A interessante nota jornalística já mencionada, publicada na edição de 14 de abril de 1895 do jornal New York Times, a respeito do projeto de reforma legislativa francesa que introduzia o direito do preso de ter um advogado desde o início, registrava as impressões do correspondente do jornal em Londres sobre as reformas no processo penal francês. Também demonstrava a impressão do homem anglo-saxão com relação ao processo penal continental dominado pelo Código de 1808. Diz (em tradução livre): "o Juge d'Instruction combina as funções de um promotor público e de um juiz instrutor, e o "Presidente", a função de um juiz [trial Judge] e de um promotor público. Evidentemente, a investidura destas competências com funções tão diversificadas e até incongruentes oferece uma grande tentação. A tendência dos oficiais de persecução em todos os países é encontrar um criminoso para todo crime e reivindicar sua própria eficiência ao levar todos os casos a uma condenação. Quando o promotor é também um magistrado, seus poderes de assegurar a prova são bastante aumentados pelo seu poder de colocar pressão no prisioneiro. Uma vez que ele aquiesceu com a prisão do réu, ele, na realidade, se comprometeu com a teoria da culpa do prisioneiro, $e$ sua tarefa é, dali por diante, condená-lo". O texto segue sugerindo que o processo penal francês da época utilizava-se da tortura que não era física, mas psicológica, para chegar a uma sentença. Disponível em: http://query.nytimes.com/mem/archive-free/pdf?res=9A06E6DB133DE433A25757C1A9629C94649ED7CF. Acessado em 22 de junho de 2014.
}

${ }^{309}$ COUTINHO, J.N.M. op. cit. p. 39. 


\section{A PRISÃO PREVENTIVA DE OFÍCIO NO BRASIL}

A partir das observações gerais tecidas acima, voltamos nossos olhos ao processual penal brasileiro, no plano da interseção entre o sistema adotado no Brasil - e os problemas decorrentes da relação de pertinência das normas - e a prisão preventiva. Procederemos inicialmente à menção de elementos históricos, passando à análise das normas constitucionais e supralegais que dispõem os princípios do sistema de justiça criminal. Por fim, trataremos da evolução legislativa infraconstitucional pós-1988 com respeito ao estabelecimento de um sistema acusatório autêntico, principalmente quanto à prisão preventiva.

\subsection{Breve delineamento histórico do processo penal brasileiro e a prisão preventiva}

Portugal implantou seu direito no Brasil durante a colonização, e as estruturas reinóis formaram a base jurídica nacional, dominada pelas inquisitórias ordenações Manuelinas e Filipinas. Absolutamente nada se aproveitou - nem aqui nem em nenhuma parte da América Latina - da organização social já instalada ${ }^{310}$. O juiz, então, representava o reforço da autoridade metropolitana ${ }^{311}$. Paralelamente, o processo canônico inquisitório fez-se presente através das chamadas Visitações do Santo Ofício, competentes para o julgamento dos delitos de crença (por exemplo: bruxaria, feitiçaria, heresia, blasfêmia) e dos costumes (como bigamia). O Livro II das Ordenações Filipinas estendia os privilégios do clero e seus juízes podiam prender leigos e proceder a penhoras ${ }^{312}$. A base do procedimento criminal dos delitos mais graves era a prisão desde o início dos procedimentos $^{313}$.

A partir da independência política em 1822, seguiram vigendo no Brasil as Ordenações Filipinas de 1603, que representavam, evidentemente, uma justiça

\footnotetext{
${ }^{310}$ STRUENSEE, Eberhard; MAIER, Julio B. J. Introdución in Las reformas. 20

311 FAORO, R. Os donos do poder. p. 220.

${ }^{312}$ ALMEIDA Jr. J.M. op. cit. p. 127-128.

${ }^{313}$ O Título 124 do Livro V das ordenações assim dispunha: "124. Da ordem do juízo nos feitos criminais. Depois que algum for preso, não será solto até que a parte a cujo requerimento for preso, ou a quem a acusação pertencer, seja citado na forma de nossas ordenações". Mencionamos, também, José Veríssimo, citado por ALMEIDA Jr. J.M. op. cit. p. 128. A Reformação da Justiça já de 1613 dispunha que nos delitos apenados com a morte, Corregedores, Ouvidores dos Mestrados e Juízes de Fora dos Reinos e Senhorios de Portugal poderiam prender antes da culpa formada.
} 
sumamente centralizada e voltada à implementação de política pública ${ }^{314}$, e que mandava seguir para os crimes graves a "ordem natural do juízo", "sem outra preocupação que não fosse a de alcançar a certeza do delito, a identificação do agente e sua confissão." ${ }^{315}$. $\mathrm{O}$ juiz, cujo poder maior ou menor sempre foi assunto de grande importância durante o império, seguia como ator principal do processo criminal. A estrutura inquisitória serviu para frear os avanços liberais ${ }^{316}$.

Com o advento da Carta de 1824, apesar da supressão de antigas ordenações marcadamente inquisitórias (como as devassas e as querelas ${ }^{317}$ ), conservou-se a justiça centralizadora. Entretanto, o debate do tempo do império focou na independência (ou falta dela) do juiz frente ao poder imperial que a Constituição reafirmou (principalmente após a dissolução da Assembleia de 1823). Restringiu-se, então, a autonomia de que os juízes gozavam, como demonstra o art. 154 daquele diploma ${ }^{318}$, muito embora três artigos antes se instituísse um "Poder Judicial independente"319 . Como disse Raymundo Faoro, “[o]s juízes de direito, escolhidos dentre bacharéis em direito, saíam das mãos do imperador, por obra e graça de sua vontade" ${ }^{320}$. Quanto à prisão, a Carta Imperial dispunha sobre a presunção de inocência a seu modo ${ }^{321}$.

\footnotetext{
314 “As Ordenações Filipinas, apenas folheadas, no Livro I, oferecem a prova das largas interferências na vida do homem colonial, em todos os seus atos, gestos c iniciativas. Pondere-se, ainda, que as atribuições locais e do governo-geral não se delimitam fixamente, como confusas são as atividades em todos os setores judiciários ou administrativos. Os juízes e oficiais fiscalizam o comércio, cuidam da justiça, expedem ordens, em controle não apenas exterior e formal como nos tempos atuais, mas em vigilância íntima e profunda." FAORO, R. op.cit. p. 219.

315 DIAS, J.F. Direito processual penal. p. 64.

${ }^{316}$ WOLKMER, A.C. História do Direito no Brasil. p. 60 e seguintes.

${ }^{317}$ ALMEIDA, J.C.M op. cit. p. XXI.

318 Art. 154. O Imperador poderá suspendel-os por queixas contra elles feitas, precedendo audiencia dos mesmos Juizes, informação necessaria, e ouvido o Conselho de Estado. Os papeis, que lhes são concernentes, serão remettidos á Relação do respectivo Districto, para proceder na fórma da Lei.

${ }^{319}$ Art. 151. O Poder Judicial independente, e será composto de Juizes, e Jurados, os quaes terão logar assim no Civel, como no Crime nos casos, e pelo modo, que os Codigos determinarem.

${ }^{320}$ FAORO, R. op. cit. p. 366.

${ }^{321}$ Art. 179. A inviolabilidade dos Direitos Civis, e Politicos dos Cidadãos Brazileiros, que tem por base a liberdade, a segurança individual, e a propriedade, é garantida pela Constituição do Imperio, pela maneira seguinte. (...) VIII. Ninguem poderá ser preso sem culpa formada, excepto nos casos declarados na Lei; e nestes dentro de vinte e quatro horas contadas da entrada na prisão, sendo em Cidades, Villas, ou outras Povoações proximas aos logares da residencia do Juiz; e nos logares remotos dentro de um prazo razoavel, que a Lei marcará, attenta a extensão do territorio, o Juiz por uma Nota, por elle assignada, fará constar ao Réo o motivo da prisão, os nomes do seu accusador, e os das testermunhas, havendo-as. IX. Ainda com culpa formada, ninguem será conduzido á prisão, ou nella conservado estando já preso, se prestar fiança idonea, nos casos, que a Lei a admitte: e em geral nos crimes, que não tiverem maior pena, do que a de seis mezes de prisão, ou desterro para fóra da Comarca, poderá o Réo livrar-se solto.
} 
Apesar do centralismo de 1824, a ordem inquisitória das ordenações que ainda regiam o processo começou a sofrer pressões devido a influências liberais inglesas e francesas, culminando no libérrimo ${ }^{322}$ Código de Processo Criminal de $1832^{323}$, no qual foi consagrada a estrutura do Tribunal do Júri (essencialmente inglesa) ${ }^{324}$, o Habeas Corpus e do juiz de paz. O aumento de poder dos juízes era um pleito liberal da época, justamente para contraponto do poder imperial, e este debate serviu à luta entre os partidos conservador e liberal. No entanto, embora já existisse a figura do Promotor Público (arts. 36 a $38^{325}$ ), o juiz era ator principal e central do processo e a prisão antes do trânsito em julgado (antes e após a culpa formada) era decidida por ele, sem necessidade de qualquer requerimento. Era, em realidade, obrigatória em crimes graves em que não caberia fiança $^{326}$. Após a prisão em flagrante e o interrogatório, o juiz, suspeitando contra o conduzido, mandava por em custódia o preso (art. 133). Agia o juiz também ex officio para a elaboração do auto de corpo de delito para formação de culpa (artigos 131 e seguintes) ${ }^{327}$.

\footnotetext{
${ }^{322}$ A expressão é do Deputado Teodoro Machado em discurso de 13 de agosto de 1870. ALMEIDA Jr. J.M. op. cit. p. 197 e seguintes.

${ }^{323}$ WOLKMER, A.C. História...p. 72-73.

324 "No período imperial, a instituição do júri foi um dos temas relevantes da controvérsia política que, em grandes linhas, opôs liberais e conservadores. Os primeiros, viram nela uma das formas de expressão do princípio da soberania popular e de restringir o poder da elite de magistrados. Os últimos raramente combateram o júri em si - "vaca sagrada” instituída a partir de conspícuos modelos europeus e americanos -, concentrando seu fogo em aspectos concretos: a incompetência dos jurados, a lentidão em ministrar justiça, a tendência a absolver, tudo conduzindo à impunidade de muitos criminosos" FAUSTO, B. Crime e cotidiano p. 227.

${ }^{325}$ Lei de 29 de novembro de 1832

Promulga o Codigo do Processo Criminal de primeira instancia com disposição provisoria ácerca da administração da Justiça Civil.

SECÇÃO III

Dos Promotores Publicos

Art. 36. Podem ser Promotores os que podem ser Jurados; entre estes serão preferidos os que forem instruidos nas Leis, e serão nomeados pelo Governo na Côrte, e pelo Presidente nas Provincias, por tempo de tres annos, sobre proposta triplice das Camaras Municipaes.

Art. 37. Ao Promotor pertencem as attribuições seguintes:

$1^{\circ}$ Denunciar os crimes publicos, e policiaes, e accusar os delinquentes perante os Jurados, assim como os crimes de reduzir á escravidão pessoas livres, carcere privado, homicidio, ou a tentativa delle, ou ferimentos com as qualificações dos artigos 202, 203, 204 do Codigo Criminal; e roubos, calumnias, e injurias contra o Imperador, e membros da Familia Imperial, contra a Regencia, e cada um de seus membros, contra a Assembléa Geral, e contra cada uma das Camaras.

$2^{\circ}$ Solicitar a prisão, e punição dos criminosos, e promover a execução das sentenças, e mandados judiciaes.

$3^{\circ}$ Dar parte ás autoridades competentes das negligencias, omissões, e prevaricações dos empregados na administração da Justiça.

Art. 38. No impedimento, ou falta do Promotor, os Juizes Municipaes nomearão quem sirva interinamente.

${ }^{326}$ Art. 101. A fiança não terá lugar nos crimes, cujo maximo da pena fôr: $1^{\circ}$ morte natural: $2^{\circ}$ galés: $3^{\circ}$ seis annos de prisão com trabalho: $4^{\circ}$ oito annos de prisão simples: $5^{\circ}$ vinte annos de degredo.

${ }^{327}$ CAPITULO III

DA PRISÃO SEM CULPA FORMADA, E QUE PÓDE SER EXECUTADA SEM ORDEM ESCRIPTA
} 
Depois da conquista liberal do Código de 32, seguiu-se a rusga entre o avanço liberal e o regresso conservador ${ }^{328}$. O Código sofreu reação conservadora da Reforma de 1841 (Lei de 3 de dezembro de 1841), que reforçou a chefia de polícia nas atribuições da Justiça. A tradição policialesca brasileira foi fortalecida ${ }^{329}$ com um “absoluto policialismo judiciário" (expressão de Sergio Adorno citada por Wolkmer) que abarcava, inclusive, o exercício de funções judiciárias por parte da polícia ${ }^{330}$. Mas o grupo de juízes que àquela época ocupavam as cadeiras do parlamento conseguiu que a reforma também tivesse intuito de restaurar o poder que a magistratura tinha na época da colônia, conferindo mais autonomia e profissionalização à classe ${ }^{331}$. Em conclusão, a reforma de 1841 criou um vínculo forte entre o governo central e os juízes ${ }^{332}$ em uma política de favorecimento da repressão e da ordem, como explicitam os discursos do parlamento à

Art. 131. Qualquer pessoa do povo póde, e os Officiaes de Justiça são obrigados a prender, e levar á presença do Juiz de Paz do Districto, a qualquer que fôr encontrado commettendo algum delicto, ou emquanto foge perseguido pelo clamor publico. Os que assim forem presos entender-se-hão presos em flagrante delicto.

Art. 132. Logo que um criminoso preso em flagrante fôr á presença do Juiz, será interrogado sobre as arguições que lhe fazem o conductor, e as testemunhas, que o acompanharem; do que se lavrará termo por todos assignado.

Art. 133. Resultando do interrogatorio suspeita contra o conduzido, o Juiz o mandará pôr em custodia em qualquer lugar seguro, que para isso designar; excepto o caso de se poder livrar solto, ou admittir fiança, e elle a dér; e procederá na formação da culpa, observando o que está disposto a este respeito no Capitulo seguinte.

(...)

Art. 144. Se pela inquirição das testemunhas, interrogatorio ao indiciado delinquente, ou informações, a que tiver procedido, o Juiz se convencer da existencia do delicto, e de quem seja o delinquente, declarará por seu despacho nos autos que julga procedente a queixa, ou denuncia, e obrigado o delinquente á prisão nos casos, em que esta tem lugar, e sempre a livramento.

328 "[V]iu-se logo que era imenso o salto do L. V das Ordenações Filipinas para o liberalíssimo regime do Código de Processo." ALMEIDA Jr., J.M. op. cit. p. 176.

${ }^{329}$ WOLKMER, A.C. História...p. 73.

${ }^{330}$ ALMEIDA Jr. J.M. op. cit. p. 192.

${ }^{331}$ Como a incompatibilidade entre a magistratura e a atuação no Parlamento só veio a ocorrer na República, havia uma forte atuação de juízes no Parlamento e muitos dos teóricos do direito conservadores que impulsionavam a reforma eram juízes de carreira e acreditavam na magistratura como a chave do sistema político estável (força social da magistratura). O grupo dos magistrados que atuavam no parlamento era tão combativo que ficaram conhecidos como "Casa dos Marimbondos". GARCIA Neto, Paulo Macedo. A Reforma Judiciária de 1871. In MOTA, C. G.; FERREIRA, G.N. (coord.). Os juristas na formação do Estado-Nação brasileiro. p. 154. Temos ainda Raymundo Faoro descortinando o poder político dos juízes: "A brecha não se abre apenas no estabelecimento do círculo, principal objetivo da lei. As incompatibilidades suscitam grande debate, sobretudo no que diz respeito ao afastamento dos magistrados dos pleitos. Desde 1848 se viera tentando a inovação, seja por meio da reforma judiciária de Nabuco, seja pela reforma eleitoral. Na reforma judiciária, tentada em 1854, fora eliminada a incompatibilidade dos juizes, pelo parecer dos deputados magistrados. Essa grande força - o político magistrado - que viera das Cortes de Lisboa e da Constituinte constituía, ainda, a maior bancada do parlamento. Dos cento e treze deputados vinte e três eram juizes, entre os quais Nabuco, Wanderley (barão de Cotegipe), Paes Barreto. A corrente favorável ao magistrado na política argumentava com a independência dele, independência assegurada com a posse do cargo, mesmo nos dias de ostracismo. Seriam de temer, segundo Zacarias, não os magistrados, mas os deputados sem emprego, que faziam da Câmara um degrau para a conquista do cargo público." FAORO, R. op. cit. p. 443.

${ }^{332}$ Idem. Ibidem. p. 151 e seguintes. 
época da instituição da Reforma ${ }^{333}$. Os procedimentos de ofício foram reafirmados ${ }^{334}$ e os crimes inafiançáveis (de prisão automática) foram ampliados (art. $38^{335}$ ).

Nos anos de 1871 a 1875 a reação conservadora foi parcialmente revertida no Gabinete Rio Branco ${ }^{336}$. A Lei 2.033, de 20 de setembro de 1871, e o Decreto 4.824, de 22 de novembro, compunham o que se chamou de Reforma de 1871. Foi criado o inquérito policial (revivendo a antiga prática da Inquisição ${ }^{337}$ e que iria marcar de forma decisiva toda a história de 150 anos, pelo menos, da justiça penal no Brasil), e modificados os institutos da fiança, da prisão preventiva, do habeas corpus, da queixa e da denúncia. Os poderes de ofício do juiz foram diminuídos ${ }^{338}$, mas a prisão preventiva ainda poderia ser

${ }^{333}$ ALMEIDA Jr., J.M. op. cit. p. 179 e seguintes. Para uma melhor compreensão desta reforma, cita-se novamente Raymundo Faoro: "O outro esteio da paz imperial virá com a reforma do Código do Processo Criminal - a Lei de 3 de dezembro de 1841. A lei de interpretação, ao retirar das províncias suas atribuições autonomistas, recebeu o complemento necessário com a legislação do ano seguinte. O poder central atrela as influências locais, armadas com a polícia e a justiça, ao comando de seus agentes. Criou, no município da corte e em cada província, um chefe de polícia, com os delegados e subdelegados a ele subordinados, nomeados pelo imperador e pelos presidentes. O juiz, de paz despe-se da majestade rural, jugulado pela autoridade policial, que assume funções policiais e judiciárias. Os juizes municipais e os promotores perdem o vínculo com as câmaras. $O$ júri desce de sua dignidade de justiça popular. $O$ legendário inspetor de quarteirão é entregue ao agente da Coroa, nomeado pelo delegado de polícia. Da reforma não escapa sequer o humilde carcereiro, perdido na insignificância de suas funções. As autoridades locais não desaparecem, senão que se atrelam ao poder central, isto é, ao partido que ocupa o ministério. Os capangas dos senhores territoriais passam a ser capangas do Império, conduzidos pelos presidentes de provincias e seus agentes". Op. cit. p. 397-398.

${ }^{334}$ Dispunha a Lei 261 de 3 de dezembro de 1841: Art. 25. Aos Juizes de Direito das Comarcas, além das attribuições que tem pelo Codigo do Processo Criminal compete: $1^{\circ}$ Formar culpa aos Empregados Publicos não privilegiados nos crimes de responsabilidade. (...) $3^{\circ}$ Proceder, ou mandar proceder ex-officio, quando lhe fôr presente por qualquer maneira algum Processo crime, em que tenha lugar a accusação por parte da Justiça, a todas as diligencias necessarias, ou para sanar qualquer nullidade, ou para mais amplo conhecimento da verdade, e circumstancias, que possão influir no julgamento. Nos crimes em que não tiver lugar a accusação por parte da Justiça, só a poderá fazer a requerimento de parte.

${ }^{335}$ Art. 38, Além dos crimes declarados no art. 101 do Codigo do Processo, não se concederá fiança: $1^{\circ}$ Aos criminosos, de que tratão os arts. 107 e 116 na primeira parte, e 123 e 127 do Codigo Criminal. $2^{\circ}$ Aos que forem pronunciados por dous ou mais crimes, cujas penas, posto que a respeito de cada um delles sejão menores, que as indicadas no mencionado art. 101 do Codigo do Processo, as igualem, ou excedão, consideradas conjunctamente. $3^{\circ}$ Aos que uma vez quebrarem a fiança.

336 "A Lei de 3 de dezembro de 1841, que havia convertido o Código de Processo Criminal em arma centralizadora, com a entrega da polícia aos agentes da corte, foi revogada na onda das reformas do gabinete Rio Branco (1871-75)" FAORO, R. op. cit. p. 546.

${ }_{337}^{337}$ FOUCAULT, M. A verdade e as formas jurídicas. p. 70 e seguintes.

${ }^{338}$ Lei 2.033 de 20 de setembro de 1871

Art. 15. Fica abolido o procedimento ex-officio dos Juizes formadores da culpa, excepto nos casos de flagrante delicto; nos crimes policiaes; e nas especies dos $\S \S 5^{\circ}$ e $7^{\circ}$ deste artigo.

$\S 1^{\circ}$ No caso de flagrante delicto, se o réo obtiver fiança, a queixa ou denuncia será apresentada dentro dos 30 dias da perpetração do delicto.

$\S 2^{\circ} \mathrm{Se}$ o réo estiver preso, a queixa ou denuncia será offerecida dentro de cinco dias. 
decretada de ofício ${ }^{339}$. Ficou mais nítida a separação entre a polícia e o judiciário, entre o inquérito e o processo. Os direitos individuais passaram à pauta dos debates e o juiz passou a ser visto como um contrabalanço da polícia. No entanto, os poderes de ofício que foram

$\S 3^{\circ}$ Não estando o réo preso nem afiançado, o prazo para a queixa ou denuncia será igualmente de cinco dias, contados da data em que o Promotor Publico receber os esclarecimentos e provas do crime ou em que este se tornar notorio.

$\S 4^{\circ}$ As autoridades competentes remetterão aos Promotores Publicos ou seus adjuntos as provas que obtiverem sobre a existencia de qualquer delicto, a fim de que elles procedam na fórma das leis.

$\S 5^{\circ} \mathrm{Se}$ esgotados os prazos acima declarados, os Promotores Publicos ou seus adjuntos não apresentarem a queixa ou denuncia, a autoridade formadora da culpa procederá ex-officio, e o Juiz de Direito multará os Promotores ou adjuntos omissos na quantia de $20 \$ 000$ a $100 \$ 000$, se não offerecerem motivos justificativos de sua falta.

$\S 6^{\circ} \mathrm{O}$ Promotor Publico, a quem o adjunto deverá communicar a queixa ou denuncia que tiver apresentado, poderá addicional-a como entender mais justo, e proseguir nos termos da formação da culpa.

$\S 7^{\circ}$ As autoridades judiciarias, sempre que reconhecerem casos de responsabilidade, formarão culpa a quem a tiver, sendo de sua competencia; e não sendo, remetterão ao Promotor Publico ou seu adjunto as provas que sirvam para fundamentar a denuncia; participando esta remessa á autoridade a quem competir a formação da culpa. Se, porém, o Promotor ou seu adjunto não officiar nos prazos dos $\S \S 1^{\circ}, 2^{\circ}$ e $3^{\circ}$, applicar-se-ha a disposição do $\S 5^{\circ}$.

\section{Decreto $\mathrm{n} .4 .824$ de 22 de novembro de 1871}

Art. 29. Aiuda antes de annunciado o processo da formação da culpa ou de qualquer diligencia do inquerito policial, o promotor publico, ou quem suas vezes fizer, e a parte queixosa, poderão requerer, e a auctoridade policial representar, ácerca da necessidade ou conveniência da prisão preventiva do réo indiciado em crime inaflançavel, apoiando-se em prova de que resultem vehemenoos indicios de culpabilidade, ou seja confissão do mesmo reo, ou documento, ou declaração de duas testemunhas; e feito o respectivo autuamento, a auctoridade judiciaria competente para a formação da culpa, reconhecendo a procedencia dos indícios contra o arguido culpado, e a conveniencia da sua pri ão por despacho nos autos a ordenará, ou expedindo mandado por escripto, ou requisitando por communicação telegraphica, por aviso geral na imprensa, ou por qualquer outro modo que faça certa a requisição.

$\S 1$. $^{\circ}$ Independente de requerimento da parte accusadora ou representação da auctoridade policial, poderá do mesmo modo o Juiz formador da culpa, julgando necessario ou conveniente ordenar ou requisitar, antes da pronuncia, a prisão do réo de crime inaflançavel, se tiver coUigido ou lhe fór presente aquella prova de que resultem vehementes indicios da culpabilidade do dito réo.

$\S 2 .^{\circ}$ A. auctoridade policial e os juizes de paz deverão fazer prender os indiciados culpados de crimes inaflanraveis, descobertos em seus districtos, sempre que tiverem conhecimento de que pela auctoridade competente para a forma «; ãO da culpa foi ordenada essa captura, ou porque recebessem directa requisição, ou por ser de notoriedade publica que o Juiz formador da culpa a expedirá.

Executada a prisão, immeiliatamente o preso eru conduzido á presença do mesmo Juiz, para d'elle dispor.

$\S 3 .^{\circ}$ Não poderá ser ordenada, nem requisitada, nem executada a prisão do réo não pronunciado, e houver decorrido um anno depoi da perpetração do crime.

(...)

Art. 44. Os Juizes de Direito das comarcas especiaes, os Juizes Municipaes dos termos das comarcas geraes, recebendo directamente, por parte da autoridade policial, o inquerito, delle tomarão conhecimento e o transmittirão ao Promotor Publico ou a quem suas vezes fizer, depois que verificarem se do mesmo inquerito resultam vehementes indicios de culpa por crime inafiançavel contra alguem; e, neste caso, reconhecida a conveniencia da prompta prisão do indiciado, deverão logo expedir o competente mandado ou requisição.

Se não existir no termo Promotor Publico ou Adjunto, nomearão pessoa idonea que sirva no caso sujeito.

Quando o proprio Juiz effectivo não puder encarregar-se da instrucção do processo, por affluencia de trabalho ou impedimento legitimo, transmittindo o inquerito ao Promotor ou Adjunto ou a quem fôr nomeado na, falta delles, deverá logo declarar que seja requerido o respectivo Substituto ou Supplente, que de preferencia é o que tem jurisdicção no districto do crime.

${ }^{339}$ Vide parágrafo $1^{\circ}$ do art. 29 do Decreto . 4.824 de 22 de novembro de 1871 em nota anterior. 
tirados do juiz foram compensados com o procedimento do inquérito policial ${ }^{340}$. As disposições de 1871 vigeram com alterações até o Código de 1941.

No desenvolvimento da doutrina e da jurisprudência, a prisão processual foi sendo restringida, pelo menos do ponto de vista estritamente legal. O juiz que determinasse prisão ilegal poderia ser punido ${ }^{341}$, e o Tribunal da Relação de Porto Alegre decidiu em 1875 que a prisão preventiva antes da culpa formada só deveria ser decretada nos termos da Lei $^{342}$. O parágrafo $4^{\circ}$ do art. 13 da já mencionada Lei 2.033 de 1871 proibia a prisão preventiva após um ano da data do crime. A disposição foi seguida, por exemplo, pelo Tribunal da Relação de São Paulo, que chegou a decidir, em abril de 1876, que passado mais de um ano do fato delituoso, seria ilegal a prisão preventiva, "tanto mais, quando não se prova que houvesse requisição em forma legal para a prisão"343.

Conforme mostramos quando aludimos às suas exposições de motivos, o Código de Processo Penal de 1941 veio suprir um reclamo pela ordem pública sobre "pseudo-direitos individuais", sob forte influência do Código fascista italiano de 1930. Era o tempo do Estado-Novo e vigência da Constituição de 1937, a "polaca", que, como o

\footnotetext{
${ }^{340}$ GARCIA Neto, Paulo Macedo. A Reforma Judiciária de 1871. In MOTA, C. G.; FERREIRA, G.N. (coord.). Os juristas na formação do Estado-Nação brasileiro. p. 160 e seguintes. De acordo com o pensamento de Joaquim Canuto, a Reforma de 1871 reestabeleceu a devassa na forma do inquérito policial. Op. cit. p. XXI e XXII.

${ }^{341}$ Lembremos as disposições do Código Criminal de 1830: "Art. 181. Ordenar a prisão de qualquer pessoa, sem ter para isso competente autoridade, ou antes do culpa formada, não rendo nos casos em que a lei o permitte.

Executar a prisão sem ordem legal escripta de legitima autoridade, exceptuados os Militares, ou Officiaes de Justiça, que incumbidos da prisão dos malfeitores, prenderem algum individuo suspeito, para o apresentarem directamente ao Juiz e exceptuado tambem o caso de flagrante delicto.

Mandar qualquer Juiz prender alguem fóra dos casos permittidos nas leis, ou mandar que, depois de preso, esteja incommunicavel além do tempo, que a Lei marcar.

Mandar metter em prisão, ou não mandar soltar della o réo, que der fiança legal nos cases, em que a lei a admitte.

Receber o Carcereiro algum preso sem ordem escripta da competente autoridade, não sendo nos casos acima exceptuados, quando não fôr possivel a apresentação ao Juiz.

Ter o Carcereiro, sem ordem escripta de competente Autoridade, algum preso incommunicavel; ou tel-o em diversa prisão da destinada pelo Juiz.

Occultar o Juiz, ou o Carcereiro, algum preso á autoridade, que tiver direito de exigir a sua apresentação.

Demorar o Juiz o processo do réo preso, ou afiançado além dos prazos legaes; ou faltar aos actos do seu livramento.

Penas - de suspensão do emprego por um mez a um anno, e de prisão por quinze dias a quatro mezes; nunca porem por menos tempo, que o da prisão do offendido, e de mais a terça parte."

${ }^{342}$ PESSOA, V.A.P. Codigo do Processo Criminal de Primeira Instancia do Brazil. p. 174.

${ }^{343}$ SALLES, J.R.C. Foro penal. p. 218.
} 
Código de Processo Penal, também é da lavra de Francisco Campos ${ }^{344}$. A Carta getulista tinha como fontes diretas o fascismo italiano e o nazismo alemão ${ }^{345}$. Dizia o legislador da ditadura Vargas em entrevista datada de 1939 que o novo Código seria "resultado de um imperativo da Constituição de 1937"346. Trata-se de um Código que, diferente do sistema misto, como visto acima, não separa, mas mescla normas típicas inquisitivas com normas típicas acusatórias. No entanto, sobressai o "forte espírito inquisitivo"347 no qual "a regra era prender o indivíduo durante o processo e mantê-lo preso durante o recurso", tornando a liberdade exceção ${ }^{348}$. O Código de 41 trazia hipóteses de prisão processual marcadamente antecipatórias da pena e até mesmo automáticas, como por exemplo a prisão decorrente da pronúncia, do art. $408, \S 1^{\circ}$ em sua redação anterior à Lei 11.689 de $2008^{349}$, e a prisão processual decorrente de sentença condenatória recorrível, do revogado art. $594^{350}$. É obvio que a prisão preventiva de ofício não poderia faltar nas disposições de um Código como este, dispondo o art. 311, em sua redação original, que em qualquer fase do inquérito policial ou da instrução criminal, caberia a prisão preventiva, decretada pelo juiz, de ofício, a requerimento do Ministério Público, ou do querelante, ou mediante

344 “O jurista era um conhecido defensor do autoritarismo. Odiava as formas democráticas de governo. Com a ascensão do fascismo e do nazismo, associou seu ultraconservadorismo à última moda europeia. Paraele, as Constituições liberais tornavam 'impossível qualquer governo'. O 'Estado era certo número de poderes concorrentes, em conflito permanente uns com os outros'. O que era preciso no Brasil? Uma Constituição com unidade, 'porque governo é um só pensamento e uma só ação'." VILLA, M.A. A história das Constituições brasileiras. p. 39. De acordo com o próprio Francisco Campos, o Código de Processo Penal de 1941 havia sido uma encomenda de 1938 aos juízes Nélson Hungria, Antônio Vieira Braga e Narcélio de Queirós e ao professor Cândido Mendes de Almeida. CAMPOS, F. O Estado nacional. p. 141.

${ }^{345}$ BONAVIDES, P.; ANDRADE, P. História constitucional do Brasil. p. 346.

${ }^{346}$ CAMPOS, F. O Estado nacional. p. 121.

${ }^{347}$ CHOUKR, Fauzi Hassan. Relatório do Brasil . In MAIER, J.B.J.; AMBOS, K.; WOISCHNIK, J. (coord.). Las reformas procesales penales em América Latina. p. 145.

${ }^{348}$ FERNANDES, A.S. Funções e limites da prisão processual. p. 1.

349 Redação original: "§ $1^{\circ} \mathrm{Na}$ sentença de pronúncia o juiz declarará o dispositivo legal em cuja sanção julgar incurso o réu, mandará lançar-lhe o nome no rol dos culpados, recomenda-lo-á, na prisão em que se achar, ou expedirá as ordens necessárias para a sua captura."

${ }^{350}$ Redação original: “Art. 594. O réu não poderá apelar sem recolher-se á prisão, ou prestar fiança, salvo se condenado por crime de que se livre solto.” Redação da Lei 5.941 de 22.11.1973: “ Art. 594. O réu não poderá apelar sem recolher-se à prisão, ou prestar fiança, salvo se for primário e de bons antecedentes, assim reconhecido na sentença condenatória, ou condenado por crime de que se livre solto." A demonstrar o casuísmo desta reforma, temos as palavras de Élio Gaspari: "Lentamente, com a inapelável sistemática do rito judicial, cercaram-no [delegado da Polícia Civil Sérgio Paranhos Fleury acusado de inúmeros atos de torturas, prisões arbitrárias e homicídios]. No final de 1973 ele parecia perdido, com a prisão preventiva decretada pelo assassinato de um traficante de tóxicos, mas o procurador-geral Oscar Xavier de Freitas tinha razão quando dizia que a sua impunidade era ponto de honra para os comandantes militares. Só um remédio heróico poderia salvá-lo, e um remédio heróico salvou-o. Em novembro de 1973, no crepúsculo do governo Medici, providenciou-se uma nova redação para o artigo 594 do Código de Processo Penal, determinando que os réus primários, com "bons antecedentes", depois de condenados, teriam direito à liberdade enquanto durasse a tramitação de seus recursos. Simples: abria-se uma porta para que o delegado respondesse em liberdade aos processos que Bicudo começara a acumular. O mandado de prisão preventiva caducara. Fleury estava livre." GASPARI, E. A ditadura escancarada. p. 383/384. 
representação da autoridade policial, quando houvesse prova da existência do crime e indícios suficientes da autoria.

O Código do Estado-Novo foi sendo reformado com o tempo e a prisão preventiva foi um dos tópicos que mais sofreram modificações. Como foi elaborado acima, em um processo penal extremamente burocratizado, moroso, hierarquizado e com uma possibilidade extremamente complexa de recursos, é natural que sua face primordial seja a prisão processual. É ela que vai legitimar o Poder Judiciário quando o trânsito em julgado pode demorar bem mais de dez anos ${ }^{351}$. Ironicamente, foi na ditadura seguinte à de Vargas que a sistemática da prisão preventiva ganhou alguns avanços teóricos e legislativos. A Lei 5.349 de 3 de novembro de 1967 terminou (teoricamente) com a prisão preventiva obrigatória $^{352}$, e a Lei 5.941 de 22 de novembro de 1973 (cognominada "Lei Fleury") modificou essencialmente o art. $594^{353}$, concedend aos réus primários e de bons antecedentes a possibilidade de apelarem da sentença condenatória em liberdade. Por fim, a Lei 6.416, de 24 de maio de 1977, restringiu ainda mais a possibilidade da prisão antes do trânsito em julgado introduzindo o parágrafo único ao art. 310, que dispunha que o juiz, ao verificar o auto de prisão em flagrante, e após ouvido o Ministério Público, poderia conceder a liberdade provisória ao réu quando não estivessem presentes quaisquer das hipóteses da prisão preventiva. Este foi o passo mais decisivo em favor da característica de cautelaridade da prisão processual.

\footnotetext{
${ }^{351}$ Esta situação de dependência da prisão processual por parte do sistema de justiça criminal não é nova. Bom exemplo na história do direito brasileiro é a discussão acerca da fiança arbitrada aos motoristas de automóveis acusados de homicídio ou de "ferimentos culposos" nos anos 20 do século XX, quando os acidentes de automóveis começavam a se tornar mais comuns. "Como os acusados não eram presos, os julgamentos iam sendo protelados até serem atingidos pela prescrição”. FAUSTO, B. Crime e cotidiano. p. 228. Desta forma, a verdadeira punição era a prisão preventiva, e, se esta não existisse, o réu sairia impune. Outro exemplo foi a retirada do dever de revisar periodicamente a medida cautelar que estava no Projeto de Lei 4.208 de 2001 que deu origem à Lei 12.0403/2011, sinal da menor importância da excepcionalidade principalmente da prisão preventiva, e da necessidade quase automática da cautelar durante o trâmite do processo penal. "Essa lacuna da lei vai continuar cobrando um preço alto no que tange ao sacrifício de direitos fundamentais e à (de)mora jurisdicional, principalmente em um país em que é bastante comum prisões cautelares se arrastarem por 3 ou 4 anos (!)" LOPES J., A. Prisões cautelares. p. 15.

352 Modificação do art. 312, cuja redação original assim dispunha: “Art. 312. A prisão preventiva será decretada nos crimes a que for cominada pena de reclusão por tempo, no máximo, igual ou superior a dez anos.", passando a dispor: "Art. 312. A prisão preventiva poderá ser decretada como garantia da ordem pública, por conveniência da instrução criminal ou para assegurar a aplicação da lei penal, quando houver prova de existência do crime e indícios suficientes da autoria."

${ }^{353}$ Redação original: "Art. 594. O réu não poderá apelar sem recolher-se à prisão, ou prestar fiança, salvo se condenado por crime de que se livre solto". Redação da Lei 5.941 de 22 de novembro de 1973: “Art. 594. O réu não poderá apelar sem recolher-se à prisão, ou prestar fiança, salvo se for primário e de bons antecedentes, assim reconhecido na sentença condenatória, ou condenado por crime de que se livre solto". O artigo 594 foi revogado pela Lei 11.719 de 2008.
} 
Essa evolução, porém, não veio acompanhada de uma partição mais equânime dos poderes processuais. A prova ainda continuava a ser regida pelo juiz e, nas audiências, o membro do Ministério Público e o advogado de defesa seguiam como meros colaboradores do juiz inquisidor. Exemplos lapidares destas observações são as audiências filmadas pela documentarista Maria Augusta Ramos em sua obra "Justiça” de 2004. O juiz continuava o centro de todos os atos e a prisão preventiva de ofício sempre vigeu. Comparte-se a conclusão de Scarance Fernandes, segundo quem o sistema brasileiro por tradição admite a prisão preventiva de ofício ${ }^{354}$.

Como foi colocado acima, os anos de exceção constitucional de 1964 a 1985 representaram uma regressão no campo dos direitos individuais no Brasil. A partir da Constituição de 1988, o panorama jurídico processual penal sofre uma inflexão.

\subsection{Plano da Constituição Federal de 1988}

No sistema jurídico, não basta a simples inoperância ou inconveniência para se taxar a norma infraconstitucional como inválida ${ }^{355}$. É preciso que se busque a relação de oposição material ou formal que a norma inferior mantém com a superior. Ao contrário da Constituição portuguesa de $1976^{356}$, por exemplo, a Constituição brasileira de 1988, marco da redemocratização do país, não traz expressamente a expressão "processo acusatório". No entanto, como foi colocado acima, a Constituição Federal de 1988, trazendo mandamentos estranhos ao ambiente de 1941, dispõe um feixe de normas ${ }^{357}$ que compõem o mandamento superior de todo o sistema de justiça penal: o princípio acusatório.

De plano, a Constituição dispõe a cláusula geral do devido processo legal (art. $5^{\circ}$, inciso LIV), condicionando a privação de liberdade ou de bens ao due process. De

\footnotetext{
${ }^{354}$ FERNANDES, A.S. Funções... p. 5.

${ }^{355}$ Como advertiu Paula Cunha Basilio, "Em um primeiro momento, importante destacar que o fato de não concordar com determinada escolha do legislador infraconstitucional não faz com que esta seja errada ou inconstitucional. É imprescindivel diferenciar aquilo que se considera ideal do que efetivamente viola o texto constitucional." BASILIO, Paula Cunha. A prisão preventiva decretada de ofício no Processo Penal Brasileiro p. 10.

356 Art. 32 (...) 5. O processo criminal tem estrutura acusatória, estando a audiência de julgamento e os actos instrutórios que a lei determinar subordinados ao princípio do contraditório.

${ }^{357}$ Conforme enumeradas em LOPES J., A. Processo Penal. p. 141.
} 
acordo com a impossibilidade de interpretação restritiva dos direitos e garantias fundamentais, é evidente que a privação de liberdade devido à prisão preventiva não escapa à regra constitucional.

A seguir, norma constitucional a se destacar é a que dispõe sobre a função institucional privativa do Ministério Público para promover a ação penal pública (art. 129, inciso I). Ressalvada a situação excepcional da ação penal privada ordinária e subsidiária da pública, em que a promoção estará a cargo do ofendido (art. $5^{\circ}$, inciso LIX), a Constituição atribui o direito potestativo do Estado (ação) a um determinado órgão, o Ministério Público ${ }^{358}$. Nos crimes de ação penal pública, portanto, “a legitimidade ativa fica a cargo do Ministério Público de forma exclusiva, ex vi, art. 129, I, tornando-se a exteriorização da própria matriz do sistema acusatório, na medida que impõe a um determinado mecanismo do Estado a persecução oficial, impossibilitando a confusão entre julgador e acusador, em estrita sintonia com todos os modelos reformistas em curso na Europa continental, 359

A interpretação reducionista (e embasada em uma matriz inquisitória), de que esta disposição constitucional significa, tão somente, a proibição do início da ação penal (ou do inquérito) por parte do juiz, deve ser superada ${ }^{360}$. Isto quer dizer que o ato de conferir a ação penal pública privativamente ao Ministério Público significa que este órgão ocupará a posição de parte acusadora, não só para iniciar a ação penal (i.e. provocar o início da tramitação do processo penal ${ }^{361}$ ), mas também para deduzir os pedidos no sentido de atingir a decisão de mérito que pretende (incluindo as medidas acauteladoras e as provas que embasam sua demanda). É também através deste dispositivo que temos a clara

\footnotetext{
${ }^{358}$ Conforme LOPES J., A. Direito procesual... p. 251.

${ }^{359}$ CHOUKR, Fauzi Hassan. Relatório do Brasil in Las reformas... p. 126

${ }^{360}$ Assim ensina Aury Lopes Jr.: "Com relação à separação das atividades de acusar e julgar, trata-se realmente de uma nota importantena formação do sistema. Contudo, não basta termos uma separação inicial, com o Ministério Público formulando a acusação e depois, ao longo do procedimento, permitir que o juiz assuma um papel ativo na busca da prova ou mesmo na prática de atos tipicamente da parte acusadora, como, por exemplo, permitir que o juiz de oficio converta a prisão em flagrante em preventiva (art. 310), pois isso equivale a "prisão decretada de ofício"; ou mesmo decrete a prisão preventiva de ofício no curso do processo (o problema não está na fase, mas, sim, no atuar de ofício!), uma busca e apreensão (art. 242), o sequestro (art. 127); ouça testemunhas além das indicadas (art. 209); proceda ao reinterrogatório do réu a qualquer tempo (art. 196); determine diligências de ofício durante a fase processual e até mesmo no curso da investigação preliminar (art. 156, incisos I e II); reconheça agravantes ainda que não tenham sido alegados (art. 385); condene ainda que o Ministério Público tenha postulado a absolvição (art. 385), altere a classificação jurídica do fato (art. 383) etc.” LOPES J., A. Direito processual penal. p. 73.

${ }^{361}$ Sobre a diferenciação entre ação penal, pretensão penal e acusação utilizamos a doutrina de LOPES J. A. op. cit. p. 251.
} 
separação entre o acusador, o defensor e o julgador, característica fulcral do sistema acusatório, como visto acima. O inciso VIII do mesmo artigo também coloca como funções institucionais a requisição de diligências investigatórias e a instauração de inquérito policial.

O contraditório e a ampla defesa, plasmados no inciso LV do art. $5^{\circ}$ da Constituição, também ensejam características tipicamente acusatórias: o método dialético e adversativo de produção de provas. Os sistemas inquisitivo ou misto podem dispensar o contraditório em razão do conhecimento e poder superior do julgador tanto de direito quanto de fato (com suas iniciativas probatórias). $\mathrm{O}$ art. $5^{\circ}$ inciso LVII traz a já mencionada presunção de inocência, incompatível com um regime em que se unem o acusador e o julgador na mesma pessoa. Por fim, temos a publicidade e a fundamentação das decisões. Já foi dito que a inquisição repele a publicidade. O texto da Constituição de 1988 também deu especial relevância para a presunção de inocência ${ }^{362}$.

A doutrina pátria, em geral, não destoa da eleição constitucional por um modelo acusatório. Vão neste sentido, por exemplo, Eugênio Pacelli ${ }^{363}$, Aury Lopes Jr. ${ }^{364}$, Geraldo Prado ${ }^{365}$, Marcellus Polastri de Lima ${ }^{366}$, Pedro Demercian e Jorge Maluly ${ }^{367}$.

Depois da vigência da Constituição de 1988, a expressão "processo penal acusatório" só veio figurar na jurisprudência do Supremo Tribunal Federal em $1996^{368}$, no julgamento do Habeas Corpus n ${ }^{\circ} 70.763 / \mathrm{SP}$, de relatoria do Ministro Celso de Mello ${ }^{369}$. A partir de então, a expressão foi utilizada principalmente induzindo à clareza na

\footnotetext{
362 "Conquanto não se trate, a rigor, de novidade em nosso ordenamento, pois na vigência do texto constitucional anterior já era sustentada a pertinência de tal princípio com os direitos e garantias especificados (art. 153, § 36 da Carta de 1969), a proclamação clara e destacada feita pelo constituinte representou uma escolha por uma concepção de processo em que a liberdade e a dignidade da pessoa humana são tidas como valores centrais do sistema punitivo". GOMES, A.M.G. Presunção de inocência e prisão processual na Lei 12.403, de 2011. p. 436.

363 “....não vemos como não se reconhecer, ou não vemos por que abdicar de um conceito acusatório de processo penal na atual ordem constitucional". OLIVEIRA, E.P. op. cit. p. 16.

364 "Compreende-se assim que o modelo constitucional é acusatório, em contraste com o CPP, que é nitidamente inquisitório.” LOPES J., A. Processo penal. p. 141.

${ }^{365}$ PRADO, G. op. cit. p. 167 e seguintes.

${ }^{366}$ LIMA, M.P. Manual de processo penal. p. 20.

${ }^{367}$ Curso de processo penal. p. 25.

368 Pesquisa realizada no sítio eletrônico de busca de jurisprudência do Supremo Tribunal Federal (http://www.stf.jus.br/portal/jurisprudencia/pesquisarJurisprudencia.asp) com a expressão "acusatório" entre as datas de $1 \% / 1 / 1989$ a $02 / 12 / 2014$.

${ }^{369}$ HC 70763, Relator(a): Min. CELSO DE MELLO, Primeira Turma, julgado em 28/06/1994, DJ 23-091994 PP-25328 EMENT VOL-01759-03 PP-00514
} 
imputação $^{370}$. Em 2002, no julgamento do Habeas Corpus $n^{\circ}$ 82.507-9 $9^{371}$, o Relator Ministro Sepúlveda Pertence entendeu que o fato do julgador receber um inquérito policial eventualmente a ele distribuído não o torna "autoridade investigadora". Ademais, entendeu que, à vista do pedido de arquivamento do inquérito por parte do Procurador Geral da República, não resta ao julgador opção senão acatar o requerimento. Arremata dizendo que "[à] ótica do leigo, essa abstinência da Justiça pode parecer cínica: resulta, porém, de um princípio basilar do Processo Penal acusatório, que impõe confiar ao Ministério Público, por seu órgão maior, o poder e a conseqüente responsabilidade de decidir da propositura ou não da ação penal’. Dois anos depois, o Ministro Maurício Corrêa, relator da ADIN 1.570-2 (que julgou a inconstitucionalidade do art. $3^{\circ}$ da revogada Lei 9.034/95), assim entendeu a incompatibilidade da legislação infraconstitucional processual penal e a Constituição de 1988: “[e]m verdade, a legislação atribuiu ao juiz as funções de investigador e inquisidor, atribuições essas conferidas ao Ministério Público e às Polícias Federal e Civil (CF, artigos 129, I e VIII e $\$ 2^{\circ}$; e 144, $\$ 1^{\circ}$, I e IV e $\left.\$ 4^{\circ}\right)$. Tal figura revelase incompatível com o sistema acusatório atualmente em vigor, que veda a atuação de ofício do órgão julgador". Por outro lado, segundo o entendimento do Ministro, o ato legislativo ordinário de conferir poderes de ofício ao juiz acabaria por "mitigar a confiabilidade do Ministério Público, cuja titularidade para a ação penal, reconhecida pela Carta Federal, seria bastante para evitar que a coleta de provas e a decisão final

\footnotetext{
${ }^{370} H C$ 73590, Relator(a): Min. CELSO DE MELLO, Primeira Turma, julgado em 06/08/1996, DJ 13-121996 PP-50162 EMENT VOL-01854-03 PP-00591; HC 80084, Relator(a): Min. CELSO DE MELLO, Segunda Turma, julgado em 09/05/2000, ACÓRDÃO ELETRÔNICO DJe-242 DIVULG 10-12-2012 PUBLIC 11-12-2012; HC 89427, Relator(a): Min. CELSO DE MELLO, Segunda Turma, julgado em 12/09/2006, DJe-055 DIVULG 27-03-2008 PUBLIC 28-03-2008 EMENT VOL-02312-04 PP-00689; HC 84436, Relator(a): Min. CELSO DE MELLO, Segunda Turma, julgado em 05/09/2006, DJe-055 DIVULG 27-03-2008 PUBLIC 28-03-2008 EMENT VOL-02312-04 PP-00631; HC 83947, Relator(a): Min. CELSO DE MELLO, Segunda Turma, julgado em 07/08/2007, DJe-018 DIVULG 31-01-2008 PUBLIC 01-02-2008 EMENT VOL-02305-02 PP-00327.

371 "I. STF: competência originária: habeas corpus contra decisão individual de ministro de tribunal superior, não obstante susceptível de agravo. II. Foro por prerrogativa de função: inquérito policial. 1. A competência penal originária por prerrogativa não desloca por si só para o tribunal respectivo as funções de polícia judiciária. 2. A remessa do inquérito policial em curso ao tribunal competente para a eventual ação penal e sua imediata distribuição a um relator não faz deste "autoridade investigadora", mas apenas the comete as funções, jurisdicionais ou não, ordinariamente conferidas ao juiz de primeiro grau, na fase pré-processual das investigações. III. Ministério Público: iniciativa privativa da ação penal, da qual decorrem (1) a irrecusabilidade do pedido de arquivamento de inquérito policial fundado na falta de base empírica para a denúncia, quando formulado pelo Procurador-Geral ou por Subprocurador-Geral a quem delegada, nos termos da lei, a atuação no caso e também (2) por imperativo do princípio acusatório, a impossibilidade de o juiz determinar de ofício novas diligências de investigação no inquérito cujo arquivamento é requerido." (HC 82507, Relator(a): Min. SEPÚLVEDA PERTENCE, Primeira Turma, julgado em 10/12/2002, DJ 19-122002 PP-00092 EMENT VOL-02096-04 PP-00766)
} 


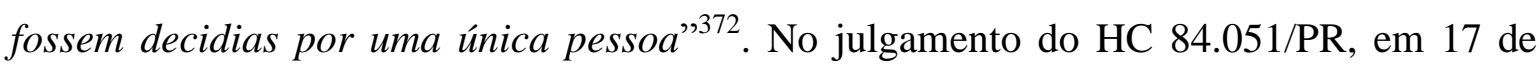
agosto de 2004, o Relator Ministro Gilmar Mendes entendeu pela possibilidade de que o juiz de primeira instância possa remeter à consideração do Ministério Público " $a$ possibilidade de se realizar ainda uma tentativa de elucidação" apesar de vigorar “atualmente, no sistema brasileiro, o sistema acusatório". Em 2008, o Ministro Carlos Brito, julgando com base no Pacto Internacional sobre Direitos Civis e Políticos, ligou o princípio acusatório ao direito de não-autoincriminação e da presunção de nãoculpabilidade $^{373}$. Ainda no mesmo ano, o tribunal restringiu mais a atuação do juiz na fase do inquérito policial no julgamento do HC $92.893^{374}$. Em 2011, o Ministro Carlos Brito foi assertivo no sentido de que o modelo acusatório foi definido pelo art. 129, inciso I da Constituição Federal ${ }^{375}$.

A partir de 2012, a aplicação do princípio acusatório começa a ganhar mais força no Supremo Tribunal Federal, a começar com o julgamento do Agravo Regimental no Inquérito $2.913^{376}$. Na ocasião, o Ministro relator do acórdão Luiz Fux consignou que "[o] sistema processual penal acusatório, mormente na fase pré-processual, reclama deva ser o juiz apenas um 'magistrado de garantias', mercê da inércia que se exige do Judiciário enquanto ainda não formada a opinio delicti do Ministério Público". Em maio do mesmo ano foi reforçada mais uma vez a separação entre julgamento e acusação na fase pré-processual e a adoção do princípio acusatório pela Constituição Federal, tendo o Ministro Relator Luiz Fux se embasado em Farrajoli ${ }^{377}$. O voto vencedor seguiu no mesmo sentido esposado no item 2 deste trabalho, tendo o acusatório como

\footnotetext{
${ }^{372}$ ADI 1570, Relator(a): Min. MAURÍCIO CORRÊA, Tribunal Pleno, julgado em 12/02/2004, DJ 22-102004 PP-00004 EMENT VOL-02169-01 PP-00046 RDDP n. 24, 2005, p. 137-146 RTJ VOL-00192-03 PP00838. No mesmo

${ }^{373}$ HC 91654, Relator(a): Min. CARLOS BRITTO, Primeira Turma, julgado em 08/04/2008, DJe-211 DIVULG 06-11-2008 PUBLIC 07-11-2008 EMENT VOL-02340-02 PP-00380 LEXSTF v. 30, n. 360, 2008, p. 327-340 RTJ VOL-00208-02 PP-00584.

374 Assentou o Ministro Relator Ricardo Lewandowski: “... o Judiciário, em nosso sistema processual penal, atua no inquérito para assegurar a observância dos direitos e liberdades fundamentais e dos princípios sobre os quais se assenta o Estado Democrático de Direito". HC 92893, Relator(a): Min. RICARDO LEWANDOWSKI, Tribunal Pleno, julgado em 02/10/2008, DJe-236 DIVULG 11-12-2008 PUBLIC 12-122008 EMENT VOL-02345-01 PP-00118.

${ }^{375}$ HC 102650, Relator(a): Min. AYRES BRITTO, Segunda Turma, julgado em 02/08/2011, ACÓRDÃO ELETRÔNICO DJe-239 DIVULG 16-12-2011 PUBLIC 19-12-2011.

${ }^{376}$ Inq 2913 AgR, Relator(a): Min. DIAS TOFFOLI, Relator(a) p/ Acórdão: Min. LUIZ FUX, Tribunal Pleno, julgado em 01/03/2012, ACÓRDÃO ELETRÔNICO DJe-121 DIVULG 20-06-2012 PUBLIC 21-062012.

377 ADI 4414, Relator(a): Min. LUIZ FUX, Tribunal Pleno, julgado em 31/05/2012, PROCESSO ELETRÔNICO DJe-114 DIVULG 14-06-2013 PUBLIC 17-06-2013
} 
princípio que funda e garante a validade de um sistema acusatório de normas processuais penais $^{378}$. No julgamento do HC 108.527, de maio de 2013, o Ministro Gilmar Mendes estabeleceu a conexão entre a paridade de armas e o princípio acusatório ${ }^{379}$. Em agosto do mesmo ano, o Supremo Tribunal Federal entendeu a requisição do juízo para o indiciamento de réu incompatível com o sistema acusatório, já que “[e]ste, contemplado em nosso ordenamento jurídico, impõe a separação orgânica das funções concernentes à persecução penal, de modo a impedir que o juiz adote qualquer postura tipicamente inerente à função investigatória" ${ }^{380}$.

Um dos últimos julgamentos do Pretório Excelso acerca do sistema acusatório talvez tenha sido o mais incisivo. Trata-se do julgamento da Medida Cautelar na Ação Direta de Inconstitucionalidade 5.104, de relatoria do Ministro Roberto Barroso, em que foi analisada a constitucionalidade de parte da Resolução 23.396 do Tribunal Superior Eleitoral que, dentre outras disposições, condiciona a instauração de inquérito policial eleitoral a uma determinação da Justiça Eleitoral. Para o desenrolar lógico de seu voto, o Ministro Relator estabelece uma premissa teórica, "a opção constitucional pelo sistema acusatório, 381.

Por fim, em agosto de 2014 o Ministro Luiz Fux entendeu que vulneraria de forma reflexa o princípio do acusatório o fato de o magistrado, após a manifestação do

\footnotetext{
378 Colhe-se de trecho do voto: "O princípio fundante do sistema ora analisado, a toda evidência, é o princípio acusatório, norma decorrente do due process of law (art. 5o, LIV, CRFB) e prevista de forma marcante no art. 129, I, da CRFB, o qual exige que o processo penal seja marcado pela clara divisão entre as funções de acusar, defender e julgar, considerando-se o réu como sujeito, e não como objeto da persecução penal. Precisa, sobre o tema, a conclusão de Luigi Ferrajoli..."

379 "Decorre do princípio da ampla defesa a necessidade de um justo equilíbrio entre as partes envolvidas em processo judicial ou administrativo. Esse equilíbrio (ou princípio da paridade das armas) está devidamente em harmonia com o sistema processual penal acusatório instituído pela Constituição Federal de 1988." (HC 108527, Relator(a): Min. GILMAR MENDES, Segunda Turma, julgado em 14/05/2013, PROCESSO ELETRÔNICO DJe-236 DIVULG 29-11-2013 PUBLIC 02-12-2013).

${ }^{380}$ HC 115015, Relator(a): Min. TEORI ZAVASCKI, Segunda Turma, julgado em 27/08/2013, PROCESSO ELETRÔNICO DJe-179 DIVULG 11-09-2013 PUBLIC 12-09-2013.

381 De acordo com trecho do voto do Ministro Roberto Barroso, "[o] traço mais marcante do sistema acusatório consiste no estabelecimento de uma separação rígida entre os momentos da acusação e do julgamento. Disso decorrem algumas consequências, sendo duas delas de especial significado constitucional. Em primeiro lugar, ao contrário do que se verifica no sistema inquisitorial, o juiz deixa de exercer um papel ativo na fase de investigação e de acusação. Isso preserva a neutralidade do Estado julgador para o eventual julgamento das imputações, evitando ou atenuando o risco de que se formem précompreensões em qualquer sentido. Uma das projeções mais intuitivas dessa exigência é o princípio da inércia jurisdicional, pelo qual se condiciona a atuação dos magistrados à provocação por um agente externo devidamente legitimado para atuar." ADI 5104 MC, Relator(a): Min. ROBERTO BARROSO, Tribunal Pleno, julgado em 21/05/2014, PROCESSO ELETRÔNICO DJe-213 DIVULG 29-10-2014 PUBLIC 30-10-2014.
} 
Ministério Público, determinar o aditamento da denúncia para incluir fatos constantes do relatório policial em função da conexão ${ }^{382}$.

De outro lado, a jurisprudência do Tribunal Supremo avançou no sentido de restrição da medida cautelar da prisão preventiva, principalmente com relação à suficiente fundamentação da decisão (evitando-se circunstâncias genéricas e impessoais), à excepcionalidade da medida e à proporcionalidade ${ }^{383}$, bem como à prisão preventiva automática (ex lege) nos casos de crimes hediondos e à duração da medida.

Essa rápida retrospectiva jurisprudencial do Supremo Tribunal Federal não tem o condão de fixar com exatidão a evolução do acusatório naquele Tribunal, mas demonstra como a jurisdição constitucional foi dando terreno ao alcance do princípio acusatório e aparando os arroubos inquisitórios do Código do Estado Novo ${ }^{384}$. No entanto, a prisão preventiva de ofício nunca foi condenada pela Corte Constitucional. Pelo contrário, sua constitucionalidade sempre foi reafirmada ${ }^{385}$. Apenas no julgamento do HC 107.317, de abril de 2012, o Ministro Marco Aurélio consignou na ementa que "a prisão preventiva pressupõe representação da autoridade competente, não cabendo transformar em regra a atuação de ofício em tal campo" ${ }^{386}$. Em setembro de 2013 , em decisão monocrática do HC 119.070, o Ministro Marco Aurélio, embora tenha concedido liminar,

\footnotetext{
${ }^{382}$ RHC 120379, Relator(a): Min. LUIZ FUX, Primeira Turma, julgado em 26/08/2014, PROCESSO ELETRÔNICO DJe-210 DIVULG 23-10-2014 PUBLIC 24-10-2014.

${ }^{383}$ Quanto ao requisito da proporcionalidade, cita-se o recente julgamento do HC 123.863 de outubro de 2014, em que o Ministro relator Teori Zavascki entendeu ser desproporcional a decretação de prisão preventiva em um caso de furto de bebedouro de água. HC 123863, Relator(a): Min. TEORI ZAVASCKI, Segunda Turma, julgado em 07/10/2014, PROCESSO ELETRÔNICO DJe-208 DIVULG 21-10-2014 PUBLIC 22-10-2014.

${ }^{384}$ Lembra-se, aqui, como era tratada a prisão preventiva pelo Supremo Tribunal Federal em 1951: “PRISÃO PREVENTIVA. PODE SER DECRETADA DE OFICIO PELO JUIZ E E OBRIGATORIA SUA DECRETAÇÃO NOS CRIMES A QUE FOR COMINADA PENA DE RECLUSÃO POR TEMPO, NO MAXIMO, IGUAL OU SUPERIOR A DEZ ANOS." (RHC 31674, Relator(a): Min. ROCHA LAGOA, SEGUNDA TURMA, julgado em 08/08/1951, ADJ DATA 26-10-1953 PP-03230 ADJ DATA 01-01-1952 PP-00432).

385 RHC 71498, Relator(a): Min. PAULO BROSSARD, Segunda Turma, julgado em 23/08/1994; HC 98968, Relator(a): Min. EROS GRAU, Segunda Turma, julgado em 04/08/2009; HC 96445, Relator(a): Min. JOAQUIM BARBOSA, Segunda Turma, julgado em 08/09/2009; HC 119630, Relator(a): Min. LUIZ FUX, Primeira Turma, julgado em 08/04/2014 (caso da prisão decretada de ofício na sentença).

${ }^{386}$ HC 107317, Relator(a): Min. MARCO AURÉLIO, Primeira Turma, julgado em 10/04/2012, PROCESSO ELETRÔNICO DJe-091 DIVULG 09-05-2012 PUBLIC 10-05-2012.
} 
consignou a validade dos artigos 310 e 311 do Código de Processo Penal, inclusive no que pertine à decretação de ofício da prisão preventiva ${ }^{387}$.

Este é, em suma, o difícil caminho - com idas e vindas ${ }^{388}$ - da democratização das instituições (mencionado na introdução deste trabalho), e o processo penal não fica à margem deste desenvolvimento.

Da mesma forma, no âmbito do Superior Tribunal de Justiça a jurisprudência que entende válida a regra da prisão preventiva de ofício é unânime, embora também lá o princípio acusatório tenha avançado. Encontramos decisões que condenam a prisão preventiva de ofício apenas no Tribunal de Justiça do Rio Grande do Sul, notadamente da lavra dos Desembargadores Nereu José Giacomolli ${ }^{389}$ e Amilton Bueno de Carvalho, que assim enunciava: "[A] regra do jogo processual democrático é assim estabelecida: um acusa, outro defende e outro julga. Ou seja, se está frente a processo penal de partes: cada uma com suas funções bem definidas. - Nesta ótica, compete ao Ministério Público, e tão somente a ele, além de promover a ação penal, atuar no interesse

\footnotetext{
${ }^{387}$ Transcreve-se trecho da decisão: "Notem a interpretação sistemática do Código de Processo Penal. O que previsto no artigo 311 nele contido segue ao que disciplinado, em termos de conversão da prisão em flagrante em preventiva, ou de ato relaxando-a, no artigo $310 \mathrm{com}$ a redação imprimida pela Lei $n^{o}$ 12.403/2011. Vale dizer: ao receber o auto de prisão em flagrante, o juiz deve, de forma fundamentada, afastá-la ou convertê-la em prisão preventiva, implementando, na primeira opção, a liberdade provisória, com ou sem fiança. Trata-se de determinação legal cuja observância independe de requerimento do Estadoacusador". Decisão monocrática liminar no HC 119.070, Rel. Min. Marco Aurélio. 9 de setembro de 2013.

${ }^{388}$ Destacamos o HC 109713/RJ em que o acusatório é descrito como um sistema que "não pressupõe magistrado como mero espectador estático no curso do processo penal, admitindo-se, ainda que excepcionalmente, a iniciativa probatória ex officio". Aí temos um exemplo do receio do juiz inativo que sustenta a validade da prisão preventiva de ofício.

389 HABEAS CORPUS. RECEPTAÇÃO. SENTENÇA CONDENATÓRIA RECORRÍVEL. ORDEM PÚBLICA. PRISÃO DE OFÍCIO. 1. O paciente, vereador licenciado para concorrer à candidatura de Deputado Estadual, foi condenado em primeiro grau, pelo delito de receptação. A pena privativa de liberdade foi substituída por restritiva de direitos, sendo, outrossim, concedido o direito de apelar em liberdade. 2. Após ter sido instado a explicar na tribuna sobre sua condenação, manifestou indignação, alegando ser inocente. Foi-lhe decretada a prisão preventiva, com fundamento na ordem pública. 3. Além de a segregação cautelar ter ferido frontalmente o sistema acusatório, pois a decretação foi de ofício, prática rejeitada pela Constituição de 1988, foi totalmente desnecessária, tendo em vista que os pronunciamentos no âmbito da Casa Legislativa, onde o paciente é vereador, criticando instituições, não ameaçam a ordem do Estado de Direito, cuja artificial reason transcende aos limites da urbe localizada. 4. Além de não haver ofensa à ordem pública, não houve demonstração de nenhuma outra situação que pudesse ensejar a decretação da custódia cautelar, tal como o risco de fuga, por exemplo. Tanto é verdade que respondeu ao processo em liberdade e lhe foi concedido o direito de apelar em liberdade. LIMINAR CONFIRMADA. ORDEM CONCEDIDA. (Habeas Corpus No 70016461592, Sétima Câmara Criminal, Tribunal de Justiça do RS, Relator: Nereu José Giacomolli, Julgado em 31/08/2006).
} 
acusatório no seu todo, tanto na deflagração da ação quanto das cautelares que sustentam o processo penal, ${ }^{390}$.

\subsection{Plano atual das normas internacionais}

Conforme foi consignado no item 1.1.1, os anos após a Segunda Guerra Mundial representaram um avanço do constitucionalismo e da proteção dos direitos individuais, tanto no campo interno dos Estados que se redemocratizavam quanto no campo do direito internacional. Nascem, dentre outros documentos internacionais protetivos de Direitos Humanos, a Declaração Universal em 1948, o Pacto Internacional dos Direitos Civis e Políticos e o Pacto Internacional dos Direitos Econômicos, Sociais e Culturais, de 1966, e a Convenção Americana de Direitos Humanos em 1969. Mais especificamente quanto ao direito das pessoas reclusas ou detidas, é de se mencionar as Regras Mínimas das Nações Unidas para o Tratamento de Presos ${ }^{391}$ que estipula a presunção de inocência dos detidos e presos provisoriamente e seu adequado tratamento ${ }^{392}$.

Aqui se coloca a relevante questão a respeito da hierarquia normativa dos tratados sobre direitos humanos ${ }^{393}$. O parágrafo $2^{\circ}$ do artigo $5^{\circ}$ da Constituição de 1988 dispõe que os direitos e garantias lá expressos não excluem outros decorrentes do regime e

390 PROCESSUAL PENAL. HABEAS CORPUS. PRISÃO DECRETADA DE OFÍCIO PELO MAGISTRADO. INCONSTITUCIONALIDADE. GARANTIA DA ORDEM PÚBLICA. REQUISITO VAGAMENTE INVOCADO. IMPRESTABILIDADE. GRAVIDADE DO DELITO - AUSÊNCIA DE PREVISÃO LEGAL. - A regra do jogo processual democrático é assim estabelecida: um acusa, outro defende e outro julga. Ou seja, se está frente a processo penal de partes: cada uma com suas funções bem definidas. - Nesta ótica, compete ao Ministério Público, e tão somente a ele, além de promover a ação penal, atuar no interesse acusatório no seu todo, tanto na deflagração da ação quanto das cautelares que sustentam o processo penal. - No momento em que o julgador invade a competência do acusador, é estabelecida uma relação incestuosa entre aquele que julga e aquele que persegue, abalando a imparcialidade - vista como eqüidistância. - A gravidade do delito não é requisito legal à prisão preventiva e, por si-só, não a pode sustentar. - A garantia da ordem pública, quando genericamente invocada, sem qualquer elemento concreto que o possa fundamentar, é imprestável a amparar prisão de caráter excepcional Concederam a ordem (unânime). (Habeas Corpus Nº 70018920934, Quinta Câmara Criminal, Tribunal de Justiça do RS, Relator: Amilton Bueno de Carvalho, Julgado em 04/04/2007).

${ }^{391}$ Adotadas pelo Primeiro Congresso das Nações Unidas sobre a Prevenção do Crime e Tratamento do delinquente, celebrado em Genebra em 1955, e aprovadas pelo Conselho Econômico e Social em suas resoluções 663C (XXIV) de 31 de julho de 1957 e 2076 (LXII) de 13 de maio de 1977. As normas deste tratado ainda fazem parte do que se chama "soft law, que consiste no conjunto de normas não vinculantes de Direito Internacional, mas que podem se transformar em normas vinculantes posteriormente, caso consigam a anuência dos Estados". RAMOS, André de Carvalho. Curso de direitos humanos. p. 276. As regras passaram a viger administrativamente no Brasil a partir da Resolução ${ }^{\circ}$ 14, de 11 de novembro de 1994 do Conselho Nacional de Política Criminal e Penitenciária (CNPCP).

392 "El acusado gozará de una presunción de inocencia y deberá ser tratado en consecuencia."

${ }^{393}$ RAMOS, A.C. op. cit. p. 513 e seguintes. 
dos princípios por ela adotados, ou dos tratados internacionais em que a República Federativa do Brasil seja parte. A emenda constitucional no 45 de 2004 incluiu, dentre outras disposições, o parágrafo $3^{\circ}$ do mesmo artigo, segundo o qual os tratados e convenções internacionais sobre direitos humanos que forem aprovados, em cada Casa do Congresso Nacional, em dois turnos, por três quintos dos votos dos respectivos membros, serão equivalentes às emendas constitucionais. A questão que restou foi a de fixar a hierarquia dos tratados e convenções internacionais sobre direitos humanos incorporados pelo Brasil antes da entrada em vigência da emenda constitucional $n^{\circ} 45$. Embora haja a posição de que os tratados internacionais sobre direitos humanos incorporados pelo direito brasileiro sejam equivalentes a leis federais ordinárias ${ }^{394}$, e outra posição segundo a qual tais tratados teriam posição hierárquica supraconstitucional, as duas posições que ressoam mais na doutrina e jurisprudência são a) a posição de hierarquia equivalente à constituição; e b) a posição supralegal e infraconstitucional. Apesar da forte tendência da doutrina no sentido da posição de equivalência com a constituição, o Supremo Tribunal Federal firmou entendimento da posição de supralegalidade dos tratados sobre direitos humanos, principalmente após o julgamento do RE 466.343, de dezembro de 2008. Neste prisma, além da própria Declaração Universal de Direitos Humanos, temos dois documentos internacionais que incidem diretamente no tema ora estudado.

\section{O Pacto Internacional dos Direitos Civis e Políticos (PIDCP),} incorporado ao direito pátrio por meio do Decreto $\mathrm{n}^{\circ} 592$ de 1992, teve a finalidade de detalhar e criar mecanismos de monitoramento internacional da implementação da Declaração Universal $^{395}$. O art. 14 do referido documento ${ }^{396}$ - que, nunca é demais

\footnotetext{
${ }^{394}$ Posição que imperava na jurisprudência do Supremo Tribunal Federal de 1988 a 2008.

${ }^{395}$ RAMOS, A.C. op. cit. p. 190.

396 Art. 14. 1. Todas as pessoas são iguais perante os tribunais e as cortes de justiça. Toda pessoa terá o direito de ser ouvida publicamente e com devidas garantias por um tribunal competente, independente e imparcial, estabelecido por lei, na apuração de qualquer acusação de caráter penal formulada contra ela ou na determinação de seus direitos e obrigações de caráter civil. A imprensa e o público poderão ser excluídos de parte da totalidade de um julgamento, quer por motivo de moral pública, de ordem pública ou de segurança nacional em uma sociedade democrática, quer quando o interesse da vida privada das Partes o exija, que na medida em que isso seja estritamente necessário na opinião da justiça, em circunstâncias específicas, nas quais a publicidade venha a prejudicar os interesses da justiça; entretanto, qualquer sentença proferida em matéria penal ou civil deverá torna-se pública, a menos que o interesse de menores exija procedimento oposto, ou processo diga respeito à controvérsia matrimonial ou à tutela de menores. 2. Toda pessoa acusada de um delito terá direito a que se presuma sua inocência enquanto não for legalmente comprovada sua culpa. 3. Toda pessoa acusada de um delito terá direito, em plena igualmente, a, pelo menos, as seguintes garantias: a) De ser informado, sem demora, numa língua que compreenda e de forma minuciosa, da natureza e dos motivos da acusação contra ela formulada; b) De dispor do tempo e dos meios necessários à preparação de sua defesa e a comunicar-se com defensor de sua escolha; c) De ser julgado sem dilações indevidas; d) De
} 
lembrar, tem natureza superior a qualquer lei federal no Brasil, incluindo o Código de Processo Penal - traz extenso rol de direitos do acusado. O tom principal é a igualdade tanto entre todos os acusados quanto entre o acusado e o acusador (traduzida no processo penal brasileiro como a "paridade de armas"). Além da presunção de inocência, que é reforçada pelo item $2^{\circ}$ do art.14, destacamos o item $1^{\circ}$, que dispõe sobre a audiência pública e com todas as garantias perante um tribunal imparcial, tanto nas acusações penais quanto nas obrigações e direitos de caráter civil. Aqui cabe uma reflexão interpretativa. $\mathrm{O}$ PIDCP garante o direito da pessoa humana de ser ouvida publicamente e com devidas garantias por um tribunal competente, independente e imparcial até mesmo para os processos que envolvam a perda de bens. Seria lógico pensar que o artigo 14(1) permite que uma decisão tão relevante como a da prisão preventiva - que, como sabemos no Brasil, pode durar anos e representar uma reprimenda superior à pena final - possa ser tomada sem qualquer tipo de audiência, de forma burocrática e de ofício? Não. E se considerarmos que o art. 14 do PIDCP paira sobre o sistema do Código de Processo Penal e, portanto, lhe condiciona a validade, qualquer norma da legislação federal que a contrarie é inválida.

O outro tratado internacional relevante para o sistema de justiça penal brasileiro é a Convenção Americana de Direitos Humanos (também chamada de Pacto de São José da Costa Rica, ou, simplesmente CADH) subscrita em 1969 e em vigor desde 1978. O Brasil aderiu ao pacto em 1992 e o promulgou por meio do Decreto n 678 de 6 de novembro do mesmo ano. As normas ali contidas também têm hierarquia supralegal segundo o STF, conforme a própria decisão do RE 466.343 (que tratava, justamente, do

estar presente no julgamento e de defender-se pessoalmente ou por intermédio de defensor de sua escolha; de ser informado, caso não tenha defensor, do direito que lhe assiste de tê-lo e, sempre que o interesse da justiça assim exija, de ter um defensor designado ex-offício gratuitamente, se não tiver meios para remunerá-lo; e) De interrogar ou fazer interrogar as testemunhas de acusação e de obter o comparecimento e o interrogatório das testemunhas de defesa nas mesmas condições de que dispõem as de acusação; f) De ser assistida gratuitamente por um intérprete, caso não compreenda ou não fale a língua empregada durante o julgamento; g) De não ser obrigada a depor contra si mesma, nem a confessar-se culpada. 4. O processo aplicável a jovens que não sejam maiores nos termos da legislação penal em conta a idade dos menos e a importância de promover sua reintegração social. 5. Toda pessoa declarada culpada por um delito terá direito de recorrer da sentença condenatória e da pena a uma instância superior, em conformidade com a lei. 6. Se uma sentença condenatória passada em julgado for posteriormente anulada ou se um indulto for concedido, pela ocorrência ou descoberta de fatos novos que provem cabalmente a existência de erro judicial, a pessoa que sofreu a pena decorrente dessa condenação deverá ser indenizada, de acordo com a lei, a menos que fique provado que se lhe pode imputar, total ou parcialmente, a não revelação dos fatos desconhecidos em tempo útil. 7. Ninguém poderá ser processado ou punido por um delito pelo qual já foi absorvido ou condenado por sentença passada em julgado, em conformidade com a lei e os procedimentos penais de cada país. 
art. $7^{\circ}$ da Convenção) $)^{397}$. O artigo $8^{\circ}$ do pacto intitulado "garantias judiciais"398 dispõe normas semelhantes às do art. 14(1) do PIDCP, concedendo o direito de toda pessoa ser ouvida em um devido processo legal na apuração tanto das infrações penais quanto nos direitos e obrigações de natureza civil, trabalhista, tributária ou de qualquer outra natureza. Destaca-se, também, a imparcialidade e independência do juízo e o direito da defesa de inquirir as testemunhas presentes no Tribunal (cross-examination), algo que só veio a ter aplicação com as reformas de 2008, embora estivessem vigentes desde 1992. Por fim, o princípio da presunção de inocência é reforçado. Magalhães Gomes lembra que antes da incorporação da CADH, ainda se pensava que a Constituição de 88 adotara apenas uma forma atenuada de não culpabilidade e não a verdadeira presunção de inocência ${ }^{399}$.

A jurisprudência da Corte Interamericana de Direitos Humanos avançou no sentido da restrição da prisão preventiva. Interpretando o artigo $7^{\circ}$ da $\mathrm{CADH}$, a Corte entendeu que "la protección de la libertad salvaguarda tanto la libertad física de las personas como su seguridad personal, en una situación en que la ausencia de garantías

\footnotetext{
397 Ressalvamos, novamente, a posição dominante na doutrina segundo a qual as normas sobre direitos humanos dispostas em tratados ou convenções retificados pelo Brasil têm status constitucional.

${ }^{398}$ Artigo 8. Garantias judiciais

1. Toda pessoa tem direito a ser ouvida, com as devidas garantias e dentro de um prazo razoável, por um juiz ou tribunal competente, independente e imparcial, estabelecido anteriormente por lei, na apuração de qualquer acusação penal formulada contra ela, ou para que se determinem seus direitos ou obrigações de natureza civil, trabalhista, fiscal ou de qualquer outra natureza.

2. Toda pessoa acusada de delito tem direito a que se presuma sua inocência enquanto não se comprove legalmente sua culpa. Durante o processo, toda pessoa tem direito, em plena igualdade, às seguintes garantias mínimas:

a. direito do acusado de ser assistido gratuitamente por tradutor ou intérprete, se não compreender ou não falar o idioma do juízo ou tribunal;

b. comunicação prévia e pormenorizada ao acusado da acusação formulada;

c. concessão ao acusado do tempo e dos meios adequados para a preparação de sua defesa;

d. direito do acusado de defender-se pessoalmente ou de ser assistido por um defensor de sua escolha e de comunicar-se, livremente e em particular, com seu defensor;

e. direito irrenunciável de ser assistido por um defensor proporcionado pelo Estado, remunerado ou não, segundo a legislação interna, se o acusado não se defender ele próprio nem nomear defensor dentro do prazo estabelecido pela lei;

f. direito da defesa de inquirir as testemunhas presentes no tribunal e de obter o comparecimento, como testemunhas ou peritos, de outras pessoas que possam lançar luz sobre os fatos;

g. direito de não ser obrigado a depor contra si mesma, nem a declarar-se culpada;e

h. direito de recorrer da sentença para juiz ou tribunal superior.

3. A confissão do acusado só é válida se feita sem coação de nenhuma natureza.

4. O acusado absolvido por sentença passada em julgado não poderá ser submetido a novo processo pelos mesmos fatos.
}

5. O processo penal deve ser público, salvo no que for necessário para preservar os interesses da justiça.

${ }^{399}$ GOMES F., A.M. Presunção de inocência e prisão processual na lei 12.403, p. 438 
puede subvertir la regla de derecho y privar a los detenidos de protección legal"400. Segue dispondo que deve existir um controle judicial imediato da prisão em flagrante com objetivo de se evitar a ilegalidade ou arbitrariedade da medida (§64), e que a prisão preventiva deve ser regida pelos princípios da legalidade, presunção de inocência, necessidade, excepcionalidade e proporcionalidade, sendo a liberdade durante todo o processo a regra geral (§67). A decisão paradigmática da Corte internacional arremata dispondo que "[1] a legitimidad de la prisión preventiva no proviene solamente de que la ley permite aplicarla en ciertas hipótesis generales. La adopción de esa medida cautelar requiere un juicio de proporcionalidad entre aquélla, los elementos de convicción para dictarla y los hechos que se investigan. Si no hay proporcionalidad, la medida será arbitraria." (§68).

Há, portanto, um sistema supralegal de normas oriundas de tratados sobre direitos humanos que informam o processo penal, condicionando todas as normas dispostas nas leis ordinárias. Tais normas, de acordo com o que foi colocado no capítulo 1 desta dissertação, dispõem um sistema processual penal autenticamente acusatório. As reformas dos processos penais em uma perspectiva global respondem a uma exigência das normas internacionais de proteção de direitos humanos ${ }^{401}$.

\subsection{Sentido das reformas das leis processuais penais: o reflexo do mandamento constitucional acusatório no plano infraconstitucional}

A partir da Constituição de 1988, o Brasil aderiu ao movimento de reforma do processo penal que já era sentido na América Latina e na Europa (sobretudo em Portugal e na Espanha). Estabelecida a garantia da imparcialidade e do sistema acusatório nas normas constitucionais e nas normas dos tratados internacionais que tratam de direitos humanos, caberia à lei delimitar e especificar a incidência desta garantia, mas nunca inviabilizando sua aplicação ou menoscabando seu alcance.

\footnotetext{
400 Caso López Álvarez vs. Honduras. Sentença de $1^{\circ}$ de fevereiro de 2006. Disponível em http://www.bjdh.org.mx/interamericano/doc?doc=casos_sentencias/CasoLopezAlvarezVsHonduras_FondoR eparacionesCostas.htm. Acessado em 8 de setembro de 2014. A prórpia sentença cita os seguintes precedentes: Caso García Asto e Ramírez Rojas, § 105; Caso Palamara Iribarne, § 196, e Caso Acosta Calderón, § 57.

${ }^{401}$ DAMAŠKKA, M. Aspectos... p. 1.
} 
A prisão preventiva obrigatória ou automática, antes prevista pelo art. 311 do CPP, fora abolida pela Lei 5.349 de 1967. Uma primeira norma infraconstitucional após a Constituição de 88 que toca diretamente o ponto aqui estudado foi a Lei 7.960 de 1989, que dispôs sobre a prisão temporária. Seguindo a tendência de retirar poderes de ofício do juiz durante o inquérito policial, o art. $2^{\circ}$ dispôs que a prisão temporária em face da representação da autoridade policial (caso em que, antes, será ouvido o Parquet, conforme $\S^{\circ}$ ) só pode ser decretada após requerimento do Ministério Público.

Tal movimento de reforma toma fôlego com a formação de uma comissão de juristas ${ }^{402}$ encarregada de modernizar o processo penal no Brasil, tendo como um dos principais objetivos o fortalecimento do sistema acusatório ${ }^{403}$. A comissão apresentou sete anteprojetos de lei em 2000, que reformularam várias dimensões da legislação processual penal.

A partir de então, com base nos trabalhos da comissão, várias leis foram promulgadas, alterando significativamente o Código de Processo Penal, principalmente no ano de 2008, com as reformas do Tribunal do Júri (Lei 11.689), provas (Lei 11.690) e a suspensão condicional do processo, a emendatio libeli, mutatio libeli e os procedimentos (Lei 11.719). Em 2009, foi sancionada a Lei 11.900, que dispôs sobre o interrogatório e outros atos processuais por videoconferência. As medidas cautelares foram completamente reformuladas pela Lei 11.403 de 2011. A análise minuciosa das reformas foge ao escopo do presente trabalho. Entretanto, alguns pontos são relevantes para a questão aqui estudada.

O sistema acusatório foi sensivelmente fortalecido com a possibilidade de inquirição direta (cross-examination) com a nova redação do art. 212 do Código, dada pela Lei $11.690^{404}$. A modificação dá novo "sabor de contenda" 405 ao ato crucial do processo e supera vetusto e inquisitório sistema de inquirição através do juiz (exemplo de

\footnotetext{
${ }^{402}$ Formada por Ada Pellegrini Grinover (Presidente), Petrônio Calmon Filho, Antônio Magalhães Gomes Filho, Antônio Scarance Fernandes, Luiz Flávio Gomes, Miguel Reale Jr., Nizardo Carneiro Leão, René Ariel Dotti, Rui Stoco, Rogério Lauria Tucci e Sidnei Beneti.

${ }^{403}$ MENDONÇA, A.B. Nova reforma... p. XII, XIII.

${ }^{404}$ Redação anterior: Art. 212. As perguntas das partes serão requeridas ao juiz, que as formulará à testemunha. O juiz não poderá recusar as perguntas da parte, salvo se não tiverem relação com o processo ou importarem repetição de outra já respondida. Redação atual: Art. 212. As perguntas serão formuladas pelas partes diretamente à testemunha, não admitindo o juiz aquelas que puderem induzir a resposta, não tiverem relação com a causa ou importarem na repetição de outra já respondida.

${ }^{405}$ Expressão de DAMAŠKKA, M. Aspectos...
} 
audiência no sistema antigo pode ser visto no documentário Justiça já mencionado). De outro lado, a Lei 11.719, que, dentre outros, alterou os art. 399 a $405^{406}$, instituiu a audiência una no procedimento comum, além da identidade física do juiz. O antigo procedimento tipicamente inquisitório de se fracionar a audiência em vários atos (que, transcritos, eram remetidos ao juiz para julgamento) foi substituído por uma única audiência, com o fito de celeridade e de aplicação da oralidade e da imediação. Mais do que simplesmente adequar o procedimento, a reforma do procedimento afasta $\mathrm{o}$ "medievalismo metodológico da busca da prova",407 e aproxima a audiência brasileira do moderno e acusatório “juízo oral” já em vigor na Espanha e em vários países da América Latina. A audiência una significa uma modificação no método de tomada de decisão pelo

${ }^{406}$ Nova redação:

Art. 399. Recebida a denúncia ou queixa, o juiz designará dia e hora para a audiência, ordenando a intimação do acusado, de seu defensor, do Ministério Público e, se for o caso, do querelante e do assistente. $\S 1$ o o acusado preso será requisitado para comparecer ao interrogatório, devendo o poder público providenciar sua apresentação. $\S 2$ o O juiz que presidiu a instrução deverá proferir a sentença

Art. 400. Na audiência de instrução e julgamento, a ser realizada no prazo máximo de 60 (sessenta) dias, proceder-se-á à tomada de declarações do ofendido, à inquirição das testemunhas arroladas pela acusação e pela defesa, nesta ordem, ressalvado o disposto no art. 222 deste Código, bem como aos esclarecimentos dos peritos, às acareações e ao reconhecimento de pessoas e coisas, interrogando-se, em seguida, o acusado. \$ 10 As provas serão produzidas numa só audiência, podendo o juiz indeferir as consideradas irrelevantes, impertinentes ou protelatórias. $\$ 2 o$ Os esclarecimentos dos peritos dependerão de prévio requerimento das partes.

Art. 401. Na instrução poderão ser inquiridas até 8 (oito) testemunhas arroladas pela acusação e 8 (oito) pela defesa. $\S 1$ o Nesse número não se compreendem as que não prestem compromisso e as referidas. $\S 2 o$ A parte poderá desistir da inquirição de qualquer das testemunhas arroladas, ressalvado o disposto no art. 209 deste Código.

Art. 402. Produzidas as provas, ao final da audiência, o Ministério Público, o querelante e o assistente e, a seguir, o acusado poderão requerer diligências cuja necessidade se origine de circunstâncias ou fatos apurados na instrução.

Art. 403. Não havendo requerimento de diligências, ou sendo indeferido, serão oferecidas alegações finais orais por 20 (vinte) minutos, respectivamente, pela acusação e pela defesa, prorrogáveis por mais 10 (dez), proferindo o juiz, a seguir, sentença.\$ 1 o Havendo mais de um acusado, o tempo previsto para a defesa de cada um será individual. § 20 Ao assistente do Ministério Público, após a manifestação desse, serão concedidos 10 (dez) minutos, prorrogando-se por igual período o tempo de manifestação da defesa. $\S 3$ o $O$ juiz poderá, considerada a complexidade do caso ou o número de acusados, conceder às partes o prazo de 5 (cinco) dias sucessivamente para a apresentação de memoriais. Nesse caso, terá o prazo de 10 (dez) dias para proferir a sentença.

Art. 404. Ordenado diligência considerada imprescindivel, de ofício ou a requerimento da parte, a audiência será concluída sem as alegações finais. Parágrafo único. Realizada, em seguida, a diligência determinada, as partes apresentarão, no prazo sucessivo de 5 (cinco) dias, suas alegações finais, por memorial, e, no prazo de 10 (dez) dias, o juiz proferirá a sentença.

Art. 405. Do ocorrido em audiência será lavrado termo em livro próprio, assinado pelo juiz e pelas partes, contendo breve resumo dos fatos relevantes nela ocorridos. § lo Sempre que possível, o registro dos depoimentos do investigado, indiciado, ofendido e testemunhas será feito pelos meios ou recursos de gravação magnética, estenotipia, digital ou técnica similar, inclusive audiovisual, destinada a obter maior fidelidade das informações. $\S 2$ o No caso de registro por meio audiovisual, será encaminhado às partes cópia do registro original, sem necessidade de transcrição.

${ }^{407}$ GIACOMOLE, N. J. Exigências e perspectivas do Processo Penal na contemporaneidade. In GAUER, R.M.C. Criminologia e sistemas jurídico-penais contemporâneos II. p. 283. 
julgador. O método anterior compreendia a oralidade somente nominal, já que os depoimentos eram todos transcritos e o julgamento era realizado pela leitura dos autos; o novo método permite que as partes inquiram as testemunhas diretamente e debatam à frente de um juiz imparcial que, exposto a esse método adversarial (que, já vimos, é o mais adequado ao sistema acusatório), profere o julgamento na própria audiência. A inquirição direta não é novidade mesmo entre os países historicamente filiados ao sistema romano-germânico como o Chile (que instituiu o cross-examination desde a vigência do novo Código) e a Suécia, por exemplo, que já a pratica há $50 \operatorname{anos}^{408}$.

A Lei 12.403 de 2011, originada do anteprojeto apresentado pela comissão acima citada (PL n. 4.208, de 2001), teve como objetivo instituir um sistema renovado de medidas cautelares no processo penal brasileiro. Com a nova lei consolidou-se o entendimento de que a prisão preventiva é a "extrema ratio, somente admissível quando o atendimento de finalidades cautelares não puder ser obtido de forma menos gravosa" ${ }^{, 409}$. Ademais, trouxe um rol de outras medidas cautelares diversas da prisão, afastando o antigo critério do "tudo ou nada"410 - liberdade ou prisão - e afirmando o caráter excepcional da prisão preventiva.

Mais precisamente quanto ao tema discutido neste trabalho, a nova redação do art. $311^{411}$ passou a permitir a prisão preventiva de ofício somente no curso da ação penal ${ }^{412}$, consagrando a tendência legislativa de restringir a atuação do juiz na fase de inquérito apenas para salvaguardar direitos fundamentais (aproximando-o a um "juiz de garantias" $)^{413}$. A impossibilidade de que o juiz aja de ofício durante a fase pré-processual encontra respaldo na parte majoritária da doutrina, mesmo dentre aqueles que sustentam a possibilidade da decretação de ofício durante o processo. Dizem Pacelli e Fischer, por exemplo, que o juiz de hoje não é mais o juiz de 1941 e que, "ainda quando produza

\footnotetext{
${ }^{408}$ TERRILL, Richard J. World Criminal Justice systems. p. 258.

${ }^{409}$ GOMES F., A.M. Presunção de inocência e prisão processual na lei 12.403, de 2011. p. 442.

${ }^{410}$ Idem. Ibidem. p. 443.

${ }^{411}$ Nova redação: Art. 311. Em qualquer fase da investigação policial ou do processo penal, caberá a prisão preventiva decretada pelo juiz, de ofício, se no curso da ação penal, ou a requerimento do Ministério Público, do querelante ou do assistente, ou por representação da autoridade policial.

${ }^{412}$ Com, pelo menos, três importantes exceções: o inciso II do art. 310, o art. 20 da Lei Maria da Penha (11.340/2006) e, especificamente quanto a medidas cautelares pessoais relativas às infrações de trânsito, o art. 294 do Código de Trânsito Brasileiro (Lei 9.503/1997).

${ }^{413} \mathrm{~A}$ mesma regra passou a ser aplicada às outras medidas cautelares com a nova redação do art. $282, \S 2^{\circ}: \S$ $2 o$ As medidas cautelares serão decretadas pelo juiz, de ofício ou a requerimento das partes ou, quando no curso da investigação criminal, por representação da autoridade policial ou mediante requerimento do Ministério Público.
} 
resultados para a qualidade da investigação", o juiz não mais pode agir de ofício antes de instaurada a ação penal, campo de atuação da polícia e do Ministério Público. Nesta fase, seguem, a atuação do juiz será de tutelar as liberdades públicas, nas causas ligadas à reserva de jurisdição. Entretanto, admitem a possibilidade "excepcionalmente, em caso de prisão em flagrante, em que sejam visíveis os riscos da restituição à liberdade (crimes praticados com violência, envolvendo grupos armados, por exemplo), no caso de inércia do parquet" ${ }^{414}$.

Outra inovação foi a legitimidade do assistente de acusação para requerer a prisão preventiva. Esta nova possibilidade gerou crítica de parte de doutrina (Geraldo Prado e Gustavo Badaró) ${ }^{415}$ que a entendem incompatível com a natureza do assistente de parte secundária (ad coadjuvandum) na relação processual. Badaró exemplifica com a hipótese de o Ministério Público ser contrário à prisão, enquanto o assistente requer e obtém do juízo a decretação ${ }^{416}$. De qualquer forma, a atuação do assistente só pode ocorrer após o recebimento da denúncia (art. 269 do CPP).

Em resumo, as reformas de 2008 e 2011 fortaleceram a presunção de inocência e trouxeram elementos tipicamente adversariais como o cross-examination e a inversão da ordem de oitiva, com o interrogatório por último ${ }^{417}$. Quanto ao regime cautelar, as leis 11.689/2008 e 11.719/2008 “aboliram as prisões decorrentes da decisão de pronúncia e da sentença condenatória de primeiro grau, submetendo-as aos mesmos requisitos da prisão preventiva" ${ }^{\text {418 }}$. Trocaram-se os antigos requisitos da primariedade $\mathrm{e}$ dos bons antecedentes pela análise dos requisitos cautelares, afastando-se a ideia de prisão preventiva como antecipação da pena e como "corolário automático da imputação"419.

Se a Lei 12.403 inegavelmente trouxe avanços, também há retrocessos ou, nas palavras de Magalhães, "fórmulas discutíveis" 420 - que devem ser mencionados. A

\footnotetext{
${ }^{414}$ OLIVEIRA, E.P.; FISCHER, D. Comentários ao Código de Processo Penal. p. 641-642.

${ }^{415}$ Cf. BADARÓ, G. Processo penal. p. 734.

${ }^{416}$ Idem. Ibidem.

${ }^{417}$ Modificações tipicamente anglo-saxãs, conforme DAMAŠKA, M. Aspectos... p. 7.

${ }^{418}$ GOMES F., A.M. Presunção de inocência e prisão processual na lei 12.403, de 2011. p. 442.

${ }^{419}$ GOMES F., A.M. Presunção de inocência e prisão processual na lei 12.403, de 2011. p. 441.

${ }^{420}$ GOMES F., A.M. Presunção de inocência e prisão processual na lei 12.403, de 2011. p. 442.
} 
nova redação do inciso III do art. $310^{421}$ possibilitou a chamada "conversão" da prisão preventiva. Assim, o juiz, ao receber o auto de prisão em flagrante, pode, sem ouvir o Ministério Público, converter a prisão em flagrante em preventiva, quando presentes os requisitos constantes do art. 312 e se revelarem inadequadas ou insuficientes as medidas cautelares diversas da prisão. Em realidade, nada há de novo, já que antes da lei de 2011, tal expediente já ocorria ${ }^{422}$. No sistema anterior, por vezes, o juiz, entendendo que não havia requisitos para a liberdade provisória, convalidava e mantinha a prisão em flagrante, que se arrastava até o julgamento do processo.

A questão é que o juiz converte a prisão em flagrante em prisão preventiva de ofício antes mesmo de requerimento neste sentido ou mesmo do oferecimento da denúncia. Surge, então, a incongruência do inciso II do art. 310 (que permite a decretação de ofício da preventiva antes de iniciada a ação penal) com o caput do art. 311 (que somente admite a decretação da prisão preventiva no curso da ação penal). Duas correntes doutrinárias principais podem ser identificadas na resolução desta questão:

a) Aqueles que rejeitam a constitucionalidade da prisão preventiva, seja na fase de investigação, seja na fase de ação penal. Por lógica, sustentam que o art. 310, inciso II é inconstitucional, i.e. não pode o juiz, ao receber o auto de prisão em flagrante, decretar a prisão preventiva sem que haja requerimento expresso do titular da ação penal. Esta é, por exemplo, a posição de Gustavo Badaró, que embora veja a restrição como positiva, entende que deveria ser mais ampla (i.e. impossibilitando a decretação de ofício em qualquer fase) ${ }^{423}$. Também esposa esta corrente Aury Lopes Jr. ${ }^{424}$.

\footnotetext{
${ }^{421}$ Nova redação: Art. 310. Ao receber o auto de prisão em flagrante, o juiz deverá fundamentadamente: (...) II - converter a prisão em flagrante em preventiva, quando presentes os requisitos constantes do art. 312 deste Código, e se revelarem inadequadas ou insuficientes as medidas cautelares diversas da prisão.

${ }^{422}$ Cita-se, por exemplo, o seguinte julgado do Supremo Tribunal Federal, de antes da vigência da Constituição de 1988: "HABEAS CORPUS. LIBERDADE PROVISORIA, PREVISTA NO ART. 310, PARAG. ÚNICO CPP. A LEI NÃO A RESTRINGE A CRIMES SEM VIOLÊNCIA, MAS APENAS AQUELES EM QUE NÃO CAIBA A PRISÃO PREVENTIVA. EMBORA A LEI NÃO EXIJA QUE O JUIZ DECRETE DE OFICIO A PRISÃO PREVENTIVA EM CADA AUTO DE FLAGRANTE QUE RECEBE, DEVE ELE DECIDIR FUNDAMENTADAMENTE DIANTE DE REQUERIMENTO DE LIBERDADE PROVISORIA, NÃO SENDO LICITO EXIGIR-SE QUE A DEFESA PROVE O NÃO CABIMENTO DA PREVENTIVA, SOB A PENA DE SE CRIAR, POR VIA OBLIQUA, HIPÓTESE DE PRISÃO SEM FUNDAMENTAÇÃO. NA ESPÉCIE, DEFERE-SE A ORDEM DE H.C., SEM PREJUIZO DO DECRETO DE CUSTODIA PREVENTIVA DIANTE DE ELEMENTOS DE PROVA QUE, REALMENTE, JUSTIFIQUEM A MEDIDA.” (RHC 66371, Relator(a): Min. DJACI FALCAO, Segunda Turma, julgado em 27/05/1988, DJ 05-08-1988 PP-18628 EMENT VOL-01509-01 PP-00185)

${ }^{423}$ BADARÓ, G. Processo penal. p. 734-735.

${ }^{424}$ LOPES J., A. Direito processual penal. p. 579.
} 
b) Para os que não enxergam inconstitucionalidade na decretação de ofício da prisão preventiva três correntes são identificadas: b1) A contradição apontada é apenas aparente, pois o caput do art. $306^{425}$ determina que a prisão preventiva seja comunicada ao Ministério Público. Dessa forma, a prisão só poderia ser decretada nesta fase com o requerimento do MP “ou como decorrência do acolhimento de representação já formulada pela autoridade policial ${ }^{\text {} 426}$. Há dois problemas fundamentais com tal posição. Primeiro, o Ministério Público pode ter vista dos autos e não realizar qualquer requerimento (nem o oferecimento da denúncia), caso em que ainda estaremos diante da possibilidade de decretação de prisão preventiva de ofício antes do início da ação penal. Segundo, como será visto mais adiante, a representação da autoridade policial não pode ser entendida como um requerimento de prisão preventiva, justamente porque a polícia não é parte da ação penal. b2) Outra posição seria a de que a conversão da prisão em flagrante em prisão preventiva (inciso II do art. 310) seria uma exceção à regra da vedação da decretação de ofício da prisão preventiva antes de iniciada a ação penal. Esta é a posição de Pacelli e Fischer ${ }^{427}$. Pacelli de Oliveira, mais especificamente, sustenta que o que é vedado ao juiz é a conversão de ofício para a prisão preventiva para fins de conveniência da investigação ou da instrução, mas não por garantia da ordem pública “quando presente o risco e a gravidade de reiteração criminosa" ${ }^{, 28}$. b3) Uma terceira corrente entende que o juiz não age de ofício quando converte a prisão em flagrante em prisão preventiva, uma vez que a prisão, na prática, já ocorreu. A atuação do juiz apenas se limitaria à verificação da manutenção da prisão ${ }^{429}$. Ocorre que, embora o efeito prático das duas modalidades de prisão (flagrante e preventiva) seja o mesmo, cada uma tem natureza diversa da outra. $\mathrm{O}$

\footnotetext{
${ }^{425}$ Art. 306. A prisão de qualquer pessoa e o local onde se encontre serão comunicados imediatamente ao juiz competente, ao Ministério Público e à família do preso ou à pessoa por ele indicada.

${ }_{426}$ MARCÃO, R. Prisões cautelares... p. 132 e seguintes.

${ }^{427}$ OLIVEIRA, E.P.; FISCHER, D. Comentários ao Código de Processo Penal. p. 641-642.

${ }^{428}$ OLIVEIRA, E.P. Curso de processo penal. p. 593-594.

${ }^{429}$ Posição esposada por Guilherme Souza Nucci, Código de Processo Penal comentado, p. 648/649, e de Andrey Borges de Mendonça qua assim a explica: "Nem se alegue que a possibilidade de o juiz converter a prisão em flagrante em prisão preventiva, prevista no art. 310, inciso II, durante o inquérito, seja um permissivo para a atuação de ofício do magistrado. Em verdade, na hipótese do art. 310, já houve uma prisão anterior em flagrante, de sorte que o magistrado não está tomando qualquer iniciativa. A prisão em flagrante já foi realizada por qualquer do povo ou pela autoridade policial e o magistrado, em verdade, apenas verifica se há necessidade de sua manutenção. O que o legislador chama de "converter" deve ser compreendido no sentido de verificar os pressupostos e fundamentação da prisão preventiva. Ou seja, essa conversão é "jurídica", no sentido de verificar os pressupostos e fundamentos da prisão preventiva. Na prática, a prisão já ocorreu e o juiz não a decreta, mas apenas verifica se é o caso de manter a prisão ou conceder a liberdade. Atua dentro de sua função de garantidor do inquérito policial, zelando para que a prisão somente seja mantida se realmente houver necessidade. Portanto, veja que, nesta hipótese, não se trata de atuação de ofício do magistrado durante o inquérito.” Prisão e outras medidas cautelares... p. 228.
} 
flagrante é uma pré-cautela ${ }^{430}$ que tem o objetivo de evitar a continuidade de prática delitiva que certamente seria objeto de um processo penal e tem a duração máxima de 24 horas (art. 306, $\S 1^{\circ}$ ), ou antes desse prazo, no caso de recebimento do autos de prisão em flagrante pelo juiz. O fundamento da prisão em flagrante, em algum destes dois casos, se extingue. A preventiva, por sua vez tem o objetivo cautelar de assegurar o curso do processo penal como garantia da ordem pública, da ordem econômica, por conveniência da instrução criminal, ou para assegurar a aplicação da lei penal, quando houver prova da existência do crime e indício suficiente de autoria. (art. 312). Trata-se de medidas absolutamente distintas com escopos diferenciados. Ao se extinguir o flagrante, não nasce, automaticamente, a prisão preventiva. Neste mesmo sentido, Nucci defende que nada há de novo no expediente do art. 310, inciso II, já que "[e]sse expediente encontra-se em vigor há décadas e somente foi aperfeiçoado pela Lei 12.403/2011" "431. No entanto, a concepção da prisão preventiva, como foi demonstrada, foi modificada e hoje, de acordo com a posição $a$, supra, não mais se tolera essa transformação natural do flagrante para a preventiva. O Superior Tribunal de Justiça interpretou o inciso II do art. 310 do CPP de forma a lhe aplicar plena validade e aplicabilidade ${ }^{432}$.

Outra discussão da mesma natureza da acima mencionada seria a da compatibilidade do preceito do caput do art. 311 do Código de Processo Penal com o art. 20 da Lei 11.340/2006 (Lei Maria da Penha) ${ }^{433}$. Há quem entenda que a proibição de prisão preventiva de ofício durante o inquérito se estenderia para as leis extravagantes ${ }^{434}$.

\footnotetext{
${ }^{430}$ LOPES J, A. Direito processual penal. p. 576 e 585.

${ }^{431}$ Op. cit. p. 649.

432 RHC 45.134/MG, Rel. Ministro FELIX FISCHER, QUINTA TURMA, julgado em 18/11/2014, DJe 28/11/2014; RHC 50.078/MG, Rel. Ministra MARIA THEREZA DE ASSIS MOURA, SEXTA TURMA, julgado em 02/10/2014, DJe 13/10/2014; RHC 47.007/MG, Rel. Ministra LAURITA VAZ, QUINTA TURMA, julgado em 21/08/2014, DJe 02/09/2014; RHC 46.796/MG, Rel. Ministro MOURA RIBEIRO, QUINTA TURMA, julgado em 10/06/2014, DJe 17/06/2014; RHC 45.203/MG, Rel. Ministra REGINA HELENA COSTA, QUINTA TURMA, julgado em 13/05/2014, DJe 19/05/2014.

${ }^{433}$ Art. 20. Em qualquer fase do inquérito policial ou da instrução criminal, caberá a prisão preventiva do agressor, decretada pelo juiz, de ofício, a requerimento do Ministério Público ou mediante representação da autoridade policial. Parágrafo único. O juiz poderá revogar a prisão preventiva se, no curso do processo, verificar a falta de motivo para que subsista, bem como de novo decretá-la, se sobrevierem razões que a justifiquem.

${ }^{434}$ Nesse sentido, CUNHA, R.S. Cometários ao art. 311. In GOMES, L.F.; MARQUES I. L. (coord.). Prisão e medidas cautelares. p. 142.
} 
Quanto aos argumentos apresentados na posição $b$, remete-se às ideias do pré-julgamento e a posição do juiz como responsável pela política de segurança pública do Estado, discutidos no capítulo 1 deste trabalho.

Como se pôde ver, apesar dos avanços, as modificações legislativas não lograram conferir um caráter autenticamente acusatório ao processo penal no Brasil. O artigo 155 , com redação dada pela Lei 11.690 de $2008^{435}$, não logrou romper a relação promíscua entre inquérito e processo, permitindo ao juiz julgar, embora não exclusivamente, com base em elementos da fase policial $^{436}$.

Quanto ao tema da prisão preventiva, elementos inquisitórios não foram superados, notadamente com relação ao método de tomada de decisão. Já foi dito que a prisão preventiva tem efeitos práticos análogos à pior sorte do réu no processo: a condenação à pena privativa de liberdade em regime fechado. Por isso, a forma de tomar a decisão, em respeito ao devido processo, deve ser análoga à do processo, por lógica. No entanto, o método de tomada de decisão e de produção de provas relativas à cognição da cautelar é essencialmente inquisitório, sem contraditório (ou com contraditório diferido), de forma escritural e com um juiz que não precisa de provocação para encarcerar. Veremos a diante que as jurisdições com reformas do acusatório mais adiantadas, como o Chile e a Espanha, criaram mecanismos de tomada de decisão cautelar mais adequadas a este sistema.

Diante do quadro infraconstitucional, identificamos os seguintes momentos da possibilidade da decretação da prisão preventiva de ofício:

\footnotetext{
435 Art. 155. O juiz formará sua convicção pela livre apreciação da prova produzida em contraditório judicial, não podendo fundamentar sua decisão exclusivamente nos elementos informativos colhidos na investigação, ressalvadas as provas cautelares, não repetíveis e antecipadas.

436 Sobre a questão, GIACOMOLLI, N.J. Exigências e perspectivas do Processo Penal na contemporaneidade. In GAUER, R.M.C. (coord.) Criminologia e sistemas jurídico-penais contemporâneos II. p. 281. No mesmo sentido Aury Lopes Jr.: "O grande erro da reforma pontual (Lei $n$. 11.690/2008) foi ter inserido a palavra 'exclusivamente'. Perdeu-se uma grande oportunidade de acabar com as condenações disfarçadas, ou seja, as sentenças baseadas no inquérito policial, instrumento inquisitório e que não pode ser utilizado na sentença. Quando o art. 155 afirma que o juiz não pode fundamentar sua decisão "exclusivamente" com base no inquérito policial, está mantendo aberta a possibilidade (absurda) de os juízes seguirem utilizando o inquérito policial, desde que também invoquem algum elemento probatório do processo.

Manteve-se, assim, a autorização legal para que os juízes e tribunais sigam utilizando a versão dissimulada, que anda muito em voga, de "condenar com base na prova judicial cotejada com a do inquérito". Na verdade, essa fórmula jurídica deve ser lida da seguinte forma: não existe prova no processo para sustentar a condenação, de modo que vou me socorrer do que está no inquérito. Isso é violar a garantia da própria jurisdição e do contraditório." Direito processual penal. p. 230. Grifos no original.
} 
$\left.1^{\circ}\right)$ Durante o trâmite do inquérito, em caso de violência doméstica e familiar contra a mulher (art. 20 da Lei 11.340/2006, com as observações interpretativas feitas acima) e no caso de conversão da prisão em flagrante em prisão preventiva (art. 310, inciso II, do CPP, com as observações interpretativas feitas acima);

\section{$\left.2^{\circ}\right)$ Durante o curso do processo penal, em qualquer momento,} notadamente se o acusado, citado por edital, não comparecer, nem constituir advogado (art. $366^{437}$ ); como substituição das medidas cautelares no caso de descumprimento (art. 282, $\S 4^{\circ}$ do $\mathrm{CPP}^{438}$ e $343^{439}$ ); no momento na sentença condenatória em que o juiz indefere o direito do réu apelar em liberdade com base no próprio decreto condenatório ou no fato de que "passou toda a instrução preso" redação dada pela lei 12.736 de $2012^{441}$ ).

Em 2008, o Senado Federal constituiu uma comissão de juristas ${ }^{442}$ encarregada da elaboração de anteprojeto de reforma do Código de Processo Penal. Os trabalhos da comissão foram concluídos em 2009, trazendo o anteprojeto avanços sensíveis no sentido do fortalecimento da coesão do sistema acusatório, como o juiz de garantias ${ }^{443}$.

\footnotetext{
${ }^{437}$ Art. 366. Se o acusado, citado por edital, não comparecer, nem constituir advogado, ficarão suspensos o processo e o curso do prazo prescricional, podendo o juiz determinar a produção antecipada das provas consideradas urgentes e, se for o caso, decretar prisão preventiva, nos termos do disposto no art. 312.

${ }^{438} \S 4$ o No caso de descumprimento de qualquer das obrigações impostas, o juiz, de ofício ou mediante requerimento do Ministério Público, de seu assistente ou do querelante, poderá substituir a medida, impor outra em cumulação, ou, em último caso, decretar a prisão preventiva (art. 312, parágrafo único).

439 Art. 343. O quebramento injustificado da fiança importará na perda de metade do seu valor, cabendo ao juiz decidir sobre a imposição de outras medidas cautelares ou, se for o caso, a decretação da prisão preventiva.

${ }_{440}$ Entendimento consolidado, por exemplo, no HC 118551, Relator(a): Min. RICARDO LEWANDOWSKI, Segunda Turma, julgado em 01/10/2013.

${ }^{441}$ Art. 387. O juiz, ao proferir sentença condenatória: (...) § 1o O juiz decidirá, fundamentadamente, sobre a manutenção ou, se for o caso, a imposição de prisão preventiva ou de outra medida cautelar, sem prejuízo do conhecimento de apelação que vier a ser interposta.

${ }^{442}$ Formada pelos juristas Antonio Correa, Antonio Magalhães Gomes Filho, Eugênio Pacelli de Oliveira (relator), Fabiano Augusto Martins Silveira, Felix Valois Coelho Júnior, Hamilton Carvalhido (coordenador), Jacinto Nelson de Miranda Coutinho, Sandro Torres de Avelar e Tito Souza do Amaral.

${ }^{443}$ De acordo com trecho da exposição de motivos, "[p]ara a consolidação de um modelo orientado pelo princípio acusatório, a instituição de um juiz de garantias, ou, na terminologia escolhida, de um juiz das garantias, era de rigor. Impende salientar que o anteprojeto não se limitou a estabelecer um juiz de inquéritos, mero gestor da tramitação de inquéritos policiais. Foi, no ponto, muito além. O juiz das garantias será o responsável pelo exercício das funções jurisdicionais alusivas à tutela imediata e direta das inviolabilidades pessoais. A proteção da intimidade, da privacidade e da honra, assentada no texto constitucional, exige cuidadoso exame acerca da necessidade de medida cautelar autorizativa do tangenciamento de tais direitos individuais. $O$ deslocamento de um órgão da jurisdição com função exclusiva de execução dessa missão atende à duas estratégias bem definidas, a saber: a) a otimização da atuação jurisdicional criminal, inerente à especialização na matéria e ao gerenciamento do respectivo
} 
No entanto, os poderes de ofício do juiz seguiram incólumes, notadamente na determinação de medidas acautelatórias, "principalmente para tutelar o regular exercício da função jurisdicional", como propõe a exposição de motivos. Quanto às medidas cautelares, o anteprojeto adota quatro diretrizes ligadas (I) à presunção de inocência; (II) à "estrutura básica" do modelo acusatório; (III) à proporcionalidade; (IV) à duração máxima da medida. Em resumo, nada há de inovação quanto ao procedimento da tomada de decisão das medidas cautelares. Reforça-se a ideia de que o juiz está impedido de tomar decisões de ofício na fase do inquérito, mas admite-se a decretação de ofício durante o processo penal, zelando "pela efetividade da jurisdição"444.

O anteprojeto deu origem ao Projeto de Lei $n^{\circ}$ 156/2009, de autoria do Senador José Sarney, já aprovado e encaminhado à Câmara dos Deputados sob o $\mathrm{n}^{\mathbf{o}}$ 8.045/2010. Com as emendas já apresentadas, o anteprojeto traz, basicamente, a mesma sistemática já a dotada hoje, de acordo com seu artigo 525 (antigo art. 513 do anteprojeto original) $^{445}$.

processo operacional; e b) manter o distanciamento do juiz do processo, responsável pela decisão de mérito, em relação aos elementos de convicção produzidos e dirigidos ao órgão da acusação."

${ }^{444}$ De acordo com a exposição de motivos, "[1]ogo, na fase de investigação, não cabe ao juiz, de ofício, inclinar-se por uma ou por outra cautelar. Como ainda não há processo, a Polícia ou o Ministério Público é que devem requerer as medidas que julgarem apropriadas, respeitando-se os papéis de cada instituição.

Com a formação do processo, já no âmbito da atuação jurisdicional, aí sim, poderá o juiz decretálas até mesmo de ofício, pois lhe compete, em última análise, zelar pela efetividade da jurisdição.

Embora adotando um roteiro bifásico, não há rigor extremado na escolha. Ressalva-se, por exemplo, expressamente, a hipótese de o juiz, de ofício, substituir a medida anteriormente imposta. Note-se que, na origem, teria havido já a provocação da autoridade policial ou do Ministério Público. No entanto, no curso da aplicação da medida cautelar, reserva-se ao juiz a possibilidade de reexaminar sua decisão, sempre que se mostrar adequada a sua substituição, como ocorre, por exemplo, na hipótese de descumprimento da cautelar por parte do investigado. Busca-se, assim, evitar leituras radicais acerca da extensão do princípio acusatório adotado."

445 "Art. 525. No curso do processo penal, as medidas cautelares serão decretadas pelo juiz, de ofício ou a requerimento das partes, observados os princípios do Código e as disposições deste Livro.

Parágrafo único. Durante a fase de investigação, a decretação depende de requerimento do Ministério Público ou de representação do delegado de polícia, salvo se a medida substituir a prisão ou outra cautelar anteriormente imposta, podendo, neste caso, ser aplicada de ofício pelo juiz." Na redação original da Comissão o art. 513 falava em "autoridade policial" em lugar de "delegado de polícia". 


\section{ANÁLISE DOS ARGUMENTOS SOBRE A VALIDADE OU INVALIDADE DA DECRETAÇÃO DA PRISÃO PREVENTIVA DE OFÍCIO}

Já indicamos na introdução deste trabalho o que entendemos por validade jurídica de uma norma (i.e. pertinência com o ordenamento jurídico e compatibilidade com as normas de hierarquia superior). O tema principal na presente dissertação é a adequação e do pertencimento das normas que dispõem a possibilidade da decretação da prisão preventiva de ofício à Constituição Federal de 1988 e aos Tratados Internacionais sobre Direitos Humanos.

Não raro os argumentos dados tanto pelos defensores da decretação de ofício quanto pelos opositores deste poder do juiz levam em conta a "verdadeira" natureza do sistema acusatório ou do "nosso" sistema acusatório ${ }^{446}$. Os primeiros sustentam que em um sistema acusatório autêntico, o juiz não deve ser passivo, não deve assumir a postura de mero espectador. Os opositores do poder cautelar de ofício sustentam que feriria a coesão do sistema acusatório dar poderes ao juiz que naturalmente pertenceriam à parte acusadora. Por tal motivo esta dissertação debruçou-se primeiramente sobre o sistema e o princípio acusatórios em cujo eixo gravitam todos os argumentos. Neste capítulo, serão analisados mais amiúde os argumentos e contra-argumentos sobre a disposição da decretação da prisão preventiva de ofício.

De acordo com Kai Ambos e Fauzi Choukr, por exemplo, se há uma tripartição de funções no sistema acusatório, o modelo em que o juiz pode tomar uma medida cautelar de ofício afasta-se de modo gritante do sistema acusatório ${ }^{447}$.

Embora ambos os lados sustentem suas teses com base no sistema acusatório, é necessário identificar a matriz dos argumentos. Do lado contrário à validade, a matriz é a imparcialidade do juiz e a importância do contraditório. Já do lado favorável à validade, a matriz é a garantia do processo (com a garantia da segurança pública,

\footnotetext{
${ }^{446}$ Embora haja alguns que indiquem que o Brasil não adota com inteireza o sistema acusatório, pois, se o fizesse, não haveria espaço para a prisão preventiva decretada de ofício. Neste sentido, FERREIRA, D.A.B. A prisão preventiva de ofício e o processo penal tipo acusatório. p. 137. Com efeito, aquele que lê o Código de Processo Penal como está vigente hoje (i.e., em 2014) não dirá que neste país vigora o sistema acusatório. No entanto, pela leitura das normas hierarquicamente superiores (a Constituição Federal e os Tratados sobre Direitos Humanos), certamente terá uma conclusão diversa.

447 "É forçoso indicar que cada vez que se confere ao magistrado ou à autoridade policial (ou a quem quer que não seja o titular da ação penal) o poder de atuar a ação penal cautelar está-se distanciando do modelo acusatório" AMBOS, K.; CHOUKR, F.H. A reforma do processo penal... p. 167-168.
} 
geralmente oculta, ou seja, em realidade subjaz o argumento da execução eficaz de eventual sentença condenatória).

Sem a intenção de esgotar todos os argumentos que possivelmente podem ser levantados, vejamos alguns principais.

\subsection{O avanço e o retrocesso}

Trata-se de uma linha de pensamento especialmente relevante para aqueles que, como Kant, entendem a história do homem como um inexorável progresso moral. Defendem alguns que não permitir que o juiz decrete a prisão preventiva de ofício seria um retrocesso. Eugênio Pacelli, por exemplo, entende como "medieval" o sistema de duelo, em que o juiz é inerte, tanto em seu Curso $^{448}$ como em palestra acerca especificamente da Lei 12.403 de $2011^{449}$. Subjaz neste argumento o receio de que o processo penal seja reduzido a um jogo entre as partes. É, de resto, o receio dos inquisidores da Idade Média que não suportavam a menor tentativa de os colocarem fora da liça. Não se trata de uma crítica à batalha de dois lados, propriamente, já que o processo inquisitivo também é uma batalha, mas um dos contendores é o magistrado, que tem interesse de "vencer" o suplicado, como nos ensina Foucault em várias passagens do Vigiar e Punir ${ }^{450}$.

\footnotetext{
448 “O processo penal moderno já superou o modelo do duelo, disputa ou de luta, no qual, a partir de uma suposta e discutível premissa da igualdade entre as partes, vence aquele que atua melhor e de maneira mais eficiente. Para nós, este é um modelo medieval, típico de ambientes que se utilizam da retórica da igualdade (que ali é sempre formal) como reforço de legitimidade de um sistema que só aparentemente é democrático." Curso de processo penal. p. 12.

449 "Como eu posso lidar com um juiz inerte no contexto atual do direito em que o processo é participado? Como é que eu posso excluir o juiz que sentencia do diálogo com as partes na fase de processo? Isso é medieval, data maxima venia. Sustentar processo de partes é medieval. É um processo de duelo: vence a parte que usa melhor o seu arsenal probatório, o seu arsenal econômico. Nós vivemos numa sociedade desigual. Nós temos que ter Defensoria Pública, e cada dia mais instrumentalizada, porque a maioria da população brasileira processada não tem direito à defesa no nível que têm a classe econômica e a classe política. Então quem quer falar em igualdade processual, vamos logo falar o jogo sério: não temos igualdade de partes no processo. Então, essa premissa é fundamental para se defender um processo de partes, um processo de duelo. Já alertava isso em 1974 um dos maiores penalistas do mundo atual, Professor Jorge de Figueiredo Dias, português coirmão." O princípio acusatório e a nova prisão preventiva. Palestra proferida no X Seminário de Direito Militar.

450 "A investigação da verdade pelo suplício do "interrogatório" é realmente uma maneira de fazer aparecer um indício, o mais grave de todos - a confissão do culpado; mas é também a batalha, é a vitória de um adversário sobre o outro que "produz" ritualmente a verdade. A tortura para fazer confessar tem alguma coisa de inquérito, mas tem também de duelo." FOUCAULT, M. Vigiar e punir. p. 37.
} 
De fato, nas sociedades primitivas o crime era tratado como um assunto particular vingado por retaliações da vítima ou de sua família. Só mais tarde o Estado passou a se apropriar da estrutura da punição, primeiro restringindo e depois proibindo a vingança particular ${ }^{451}$. No Direito Romano, a diferença entre interesses penais privados e públicos não era nítida. $O$ Estado legitimava a vingança particular, restringindo sua atuação direta à aplicação da pena para os crimes graves contra o próprio Estado ${ }^{452}$. Como vimos, em um sentido puramente cronológico, o duelo acusatório (uma modalidade de processo acusatório $^{453}$ ) figurou na história do processo antes da estrutura inquisitória ${ }^{454}$. E o desenvolvimento inicial destes dois sistemas deu-se antes da Idade Média, ainda em Roma. A era medieval conheceu, no seu início, um processo de duelo - muitas vezes físico - entre as partes. No entanto, foi na Baixa Idade Média que as estruturas inquisitórias ressurgiram até chegarem a um apogeu. O Canal da Mancha, então, separou o desenvolvimento de dois sistemas processuais penais distintos.

Conforme foi colocado no capítulo anterior, enquanto a essência do processo penal anglo-saxão permaneceu sem alterações profundas a partir do século XVIII, o continente foi palco de permanentes processos de reforma de seu processo penal, em um movimento de aproximação do processo acusatório e afastamento do modelo inquisitório. O nascedouro destas reformas foi o pensamento dos juristas reformadores do século das luzes, que tinham a justiça penal do período republicano da Roma antiga como exemplo de escudo das liberdades individuais. É bem verdade que movimentos de contrarreforma bem sucedidos, notadamente nos regimes de corte fascista na primeira metade do século XX (e seus sectários um tanto mais longevos, como o salazarismo e o franquismo), lograram reinstituir a primazia do juiz sobre o processo. Contudo, a partir da derrota destes regimes na Segunda Grande Guerra, o movimento reformista voltou a marcar o processo penal com a essência de um juiz que julga e não tem a responsabilidade sobre a segurança pública do Estado sobre suas costas.

\footnotetext{
${ }^{451}$ BAUMAN, R.A. Crime and punishment in Ancient Rome. p. 2.

${ }^{452}$ ILLUMINATI, G. op. cit. p. 299.

${ }^{453} \mathrm{O}$ direito germânico antigo implicava em uma disputa, mas uma disputa privada, o que leva Julio Maier a chamar esse sistema de "acusatório privado". MAIER, J.B. Derecho Procesal Penal. P. 264 e seguintes.

${ }^{454}$ Interessante notar que a palavra duelo pode ser usada como um combate físico oriundo do Direito Gerânico antigo e que foi utilizado no Reino Unido (trial by combat, wager of battle, trial by battle ou judicial duel) até sua abolição em 1819. Ainda em 1818, no caso Ashford vs. Thornton (106 ER 149), a Court of King's Bench concedeu o direito do réu, após a absolvição, duelar contra seu acusador. BARNEWALL, R.V.; ALDERSON, E.H. Reports of cases argued and determined in The Court of King's Bench p. 405.
} 
Aqui cabe uma digressão extremamente relevante para a análise histórica da evolução do processo. Como nos explica o historiador britânico Eric Hobsbawm ${ }^{455}$, os movimentos contrarrevolucionários da primeira metade do século XX traziam em seu bojo a "nostalgia ideológica de uma Idade Média imaginária", até então - pelo menos no século XIX - apenas sustentada pelas barreiras erguidas pelos dogmas da Igreja Católica Romana contra as superiores forças do modernismo. A imagem da Idade Média com que os fascistas ${ }^{456}$ sonhavam é, sem dúvida, a sua parte final, em que a Igreja resgatou o poder central e imperial - a ordem (palavra recorrente no processo penal brasileiro hodierno) que havia desaparecido após a queda do Império Romano do Ocidente. Há, portanto, uma ligação histórica entre a Baixa Idade Média (e sua instituição central: a Igreja Católica Romana) e os movimentos da "contrarrevolução revolucionária"457 dos regimes fascistas. Não é por acaso que a justiça penal dos dois momentos se aproxima. São ambos vertentes de pensamento contrailuministas, já que o Iluminismo, como visto, intentou afastar o processo penal das práticas inquisitórias e aproximá-lo da tradição em vigor na GrãBretanha.

Em suma, dizer que um processo de partes é medieval, além de inexato, é equívoco. Há duas tradições distintas de processo penal nas fases da Idade Média, e a mais forte e duradoura é justamente a estrutura inquisitória que nos foi legada pela Igreja medieval.

\subsection{Argumento do interesse público e sua refutação}

Trata-se do argumento de mais peso entre os sequazes da plena validade de toda sorte de normas de atuação de ofício do juiz no processo penal. No entanto, ganha especial relevância na questão da prisão preventiva, da segregação liminar do suposto perpetrador da ação delituosa. Uma vez que a jurisdição tenha sido provocada a atuar

\footnotetext{
${ }^{455}$ HOBSBAWN, E. Age of extremes. pp. 110 e seguintes.

${ }^{456}$ Como Hobsbawn, utilizamos as palavras fascistas (ou fascismo) como um gênero do qual o regime italiano de Mussolini, o nazista de Hitler e o croata da Ustaše são espécies. Além destes, também apresentam características semelhantes os regimes que, embora não sejam propriamente fascistas, aproximam-se bastante deste modelo, como o do Professor Antonio Salazar em Portugal, do Caudillo de España Francisco Franco (que Hobsbawm chama de "unfinished business of the Second World War"), e o Estado Novo do Presidente Vargas, que deu a luz ao atualmente vigente Código de Processo Penal. Para a relação entre a ideologia estatal e a justiça penal, veja-se o capítulo 1 .

${ }^{457}$ Percuciente e cheia de sentido expressão de Hobsbawm.
} 
diante de um delito penal, a ordem pública, a paz social, o interesse público, caem sobre as costas do julgador. Desta forma, o juiz deve dispor dos instrumentos necessários e suficientes para tanto, ou seja, se é o juiz o responsável pela ordem pública (e fala em nome do interesse público), não pode submeter-se a requerimentos das partes para agir. Visto de maneira prática, o argumento significa que, percebendo o juiz presentes os fatos e fundamentos da segregação cautelar, não há motivo para se aguardar o pedido do acusador. Pelo contrário, motivos não faltam para a ação sponte sua. Em realidade, presentes os requisitos, tornar-se-ia um dever do juiz a decretação da prisão preventiva ${ }^{458}$.

De acordo com tal argumento, o juiz não pode ser um árbitro (ao contrário do que propunha Pimenta Bueno). Diminuí-lo à mera condição de expectador reduz sua função e pode gerar injustiças, principalmente quando uma ou ambas as partes (acusador ou defensor) não cumprem sua função a contento. Com efeito - conforme se pode depreender das recentes decisões em favor da validade da prisão preventiva de ofício - o juiz é tão central e especializado que pode e deve tomar a decisão de encarceramento quando os elementos do inquérito bastam para tanto (caso da "nova" conversão da prisão em flagrante em preventiva do inciso II do art. 310 do CPP). Ora, se os elementos do inquérito já delineiam os requisitos da prisão preventiva, o requerimento de qualquer parte é desnecessário, inútil ou, até mesmo, pernicioso para a alta função do juízo. Aplicam-se neste caso as conclusões de Damaška, quando trata do ideal hierárquico da burocracia do sistema de justiça. Embora esteja contrastando o esquema em que profissionais especializados se contrapõem à estrutura de profissionais leigos da comunidade, pode-se aplicar neste caso a ideia de que, em um sistema hierarquizado como sem dúvida é o nosso, o corpo profissional da justiça acaba separando as opiniões em insiders e outsiders ${ }^{459}$. O interessante é que o outsider, no caso brasileiro, é o próprio Ministério Público.

Ilustra-se esse argumento pars pro toto com a seguinte passagem de monografia escrita sobre o tema: "Instaurado o processo, o juiz se torna o "presidente" da

\footnotetext{
${ }^{458}$ Se quem decide se há ou não os requisitos legais, em última análise, é o juiz e se este entende que há os requisitos, pode ordenar desde já. Trata-se da pergunta de Carnelluti: "desde o momento em que no processo penal, existindo a notícia que o delito deve acontecer, que necessidade tem o juiz de pedir permissão ao ministério público?" CARNELUTTI, F. Cuestiones sobre el proceso penal p. 215. Diz Carnelutti que o fato de a doutrina recorrer à figura de um magistrado bifronte (metade juiz e metade ministério público) é sinal de sua viscosidade dos conceitos, para não dizer de erros.

459 "If outside participation in the making of decisions is imposed upon such officials, it is viewed, at best, as meddling which deserves to be contained and made innocuous.". DAMAŠKA, M. The faces... loc. 5355 of 6774.
} 
ação penal, cabendo a ele assegurar seu regular processamento e garantir, ao mesmo tempo, os direitos fundamentais do réu e também os interesses da sociedade. Para isso, deve o magistrado dispor de instrumentos necessários para garantia da efetividade do processo, não podendo ficar dependente de uma atuação anterior do Ministério Público ou do réu. Foi com base nesta mesma ideia que o art. 385 do CPP permitiu que o juiz proferisse sentença condenatória ainda que o parquet tenha opinado pela absolvição do acusado. Vislumbrando, por exemplo, que as testemunhas vem sendo ameaçadas pelo réu que se encontra solto e diante da inércia do membro do Ministério Público, deveria a figura presidencial do juiz ficar de mãos atadas e ver prejudicado todo o regular desenvolvimento da persecução acusatória que interessa à coletividade como um todo? Acredita-se que não". O mesmo trabalho trata o juiz como "garantidor do regular processamento da ação penal ${ }^{, 460}$.

Este argumento revela como nenhum outro a lógica interna do sistema inquisitório, exposta de forma objetiva por Francisco Campos na exposição de motivos do Código atualmente vigente.

Para além da já estabelecida discussão a respeito da vagueza proposital das expressões "interesse público", “ordem pública"461 ou mesmo "ordem econômica", exsurge do argumento a figura central e quase sempre autossuficiente do juiz - pelo menos para decisões de extrema relevância no processo, como é a segregação cautelar -, matriz do sistema inquisitório. Lembramo-nos dos tempos da Santa Inquisição, quando a doutrina

\footnotetext{
${ }^{460}$ BASILIO, P.C. A prisão preventiva decretada de ofício no Processo Penal Brasileiro. p. 10.

${ }^{461}$ Para Magalhães Gomes: “[n]o caso especial da prisão cautelar, o apelo à 'ordem pública' representa, em última análise, a superação dos limites impostos pelo princípio da legalidade estrita, que se postula fundamental à matéria, para propiciar a atribuição de um amplo poder discricionário ao juiz, que nesse particular não fica sujeito a limitações senão da própria 'sensibilidade'. Apesar dessa apontada nebulosidade, o recurso à 'ordem pública' em matéria penal e processual-penal tem uma destinação bastante clara: a de fazer prevalecer o interesse da repressão em detrimento dos direitos e garantias fundamentais. GOMES F., A.M. Presunção de inocência e prisão cautelar. p. 67 . De acordo com Aury Lopes Jr.: “Garantia da ordem pública: por ser um conceito vago, indeterminado, presta-se a qualquer senhor, diante de uma maleabilidade conceitual apavorante, como mostraremos no próximo item, destinado à crítica. Não sem razão, por sua vagueza e abertura, é o fundamento preferido, até porque ninguém sabe ao certo o que quer dizer... Nessa linha, é recorrente a definição de risco para ordem pública como sinônimo de "clamor público", de crime que gera um abalo social, uma comoção na comunidade, que perturba a sua "tranquilidade". Alguns, fazendo uma confusão de conceitos ainda mais grosseira, invocam a "gravidade" ou "brutalidade" do delito como fundamento da prisão preventiva. Também há quem recorra à "credibilidade das instituições" como fundamento legitimante da segregação, no sentido de que se não houver a prisão, o sistema de administração de justiça perderá credibilidade. A prisão seria um antídoto para a omissão do Poder Judiciário, Polícia e Ministério Público. É prender para reafirmar a "crença” no aparelho estatal repressor.” LOPES Jr., A.L. Direito processual penal. p. 607-608 (grifo no original).
} 
oficial da Igreja era firme no sentido de que o inquisidor "era um pai espiritual imparcial cujas funções na salvação das almas não poderiam ser restringidas por regra alguma"

O ponto tange a já referida relação entre o sistema político e a estrutura processual e os dois arquétipos de organização política estatal estabelecidos por Damaška: 1) o Estado comprometido com a resolução do conflito; em oposição ao 2) Estado comprometido com a implementação da política pública. O juiz ativo e autossuficiente é elemento característico de uma Justiça que busca a implementação de certa política pública em que o centralismo autoritário tende a acumular as funções nas mãos do poder, e o cidadão não é, necessariamente, o representante de seu próprio interesse ${ }^{463}$. Pode-se entender, mutatis mutandis, no sistema processual brasileiro, que o Ministério Público e o ofendido não são os melhores acusadores, ou, pelo menos, não podem ser os únicos. O modelo de implementação de política ao qual se adéqua o inquisitório, exige um juiz que dê uma decisão acurada ou mais apropriada e, assim, deve ser ativista. O juiz no sistema de justiça que implementa política é ativista e deve atuar sempre para chegar à decisão certa (i.e mais justa). É claro que tal decisão mais certa, mais justa, pode estar fora das intenções de ambas as partes ${ }^{464}$. De acordo com Damaška, se as partes (acusador e réu) desistem de contender, somente alguém determinado a cumprir certos anseios de justiça pode tomar seus lugares e manter o processo em movimento ${ }^{465}$. Temos aí o juiz como um agente da política pública do Estado, em oposição ao juiz que imparcialmente julga de forma mais imparcial possível as controvérsias que lhe são colocadas à frente.

Em oposição, em um sistema de justiça reativo, ou seja, que dedica-se a resolver conflitos, a corte tende a ser vista como um espaço justo para a resolução de conflitos. Discorrendo sobre como seria o julgador ideal, Damaška pergunta o que as partes esperam quando vão a juízo. Conclui que a maioria delas espera um juiz imparcial que trate as partes com igualdade, objetividade e neutralidade ${ }^{466}$. Por outro lado, é evidente que a parte acusadora tenda a preferir um juiz que possa tomar decisões a seu favor,

\footnotetext{
${ }^{462}$ LEA, H.C. A History of the Inquisition of the Middle Ages. Loc. 6555 of 11831. Tradução livre.

${ }^{463}$ DAMAS̆KA, M. The faces... Loc 3163 of 6774

${ }^{464}$ DAMAŠKA, M. The faces... Loc 3502 of 6774

465 "Where government is conceived as a manager, the administration of justice appears to be devoted to fulfillment of state programs and implementation of state polices". DAMAŠKA, M. The faces... Loc 320 and 2297 of 6774.

${ }^{466}$ DAMAŠKA, M. The faces... Loc 2818 of 6774.
} 
mesmo que não sejam requeridas expressamente. Isso, contudo, enfraquece sua própria posição como parte.

Muitas vezes, junto ao interesse público encontramos outra expressão análoga que sustenta o papel do juiz ativo na segregação cautelar: o clamor público. O juiz que atende ao clamor público (algumas vezes confundido com as interpretações e os sensacionalismos dos meios de comunicação, como lembram Maciá e Roig ${ }^{467}$ ), atribui à prisão preventiva um papel essencialmente de direito material, de prevenção geral e de exemplo de ação da Justiça (na verdade, de atuação da política pública do Estado). Trata-se de mais uma característica da fraude de etiquetas já tratada.

O juiz responsável pela implementação da política de segurança pública, além de deixar a imparcialidade de lado (visto que esta não é a característica mais importante deste sistema ${ }^{468}$ ), falha quando um crime ocorre e alguém não é apenado, como o juiz inquisidor falhava quando não conseguia vingar uma heresia ${ }^{469}$. Por isso foi dito antes que o juiz atua por obrigação (poder-dever) quando decreta uma prisão preventiva de ofício.

Temos, portanto, um interesse público definido de forma unilateral pelo juiz. Trata-se em realidade de imposição de poder disfarçada de interesse público, que permite que o juiz tome a decisão interlocutória mais importante do processo sem o devido processo legal (i.e. sem contraditório e sem a ampla defesa). Estes valores do due process são, por definição, mais prestigiados em sistemas de Justiça mais reativos que pró-ativos, ou seja, que se incumbem em resolver conflitos e não implementar uma política de segurança pública. A decisão interlocutória de encarcerar o réu é, neste sentido, uma deturpação dos valores processuais acusatórios. Já foi mencionado que, de acordo com Goldschmidt, à exigência punitiva contrapõe-se à pretensão no sentido processual, que não pode ser exercida pelo juiz. Pretensão no sentido processual deve ser entendida não como "un derecho proprio y la petición de la adjudicación del mismo", mas como "la

\footnotetext{
${ }^{467}$ MACIÁ G., R.; ROIG A., M. El nuevo sistema de adopción de la medida cautelar de la prisión provisional. p. 76.

${ }_{468}$ Para Damaška, o modelo de implementação de política requer a ideia de um juiz justo mais clara que um juiz imparcial. DAMAŠKA, M. The faces... Loc 3461 of 6774.

${ }^{469}$ Para uma descrição precisa e completa do juiz inquisidor, ver a clássica obra de LEA, A History.. v. 1 loc. 6477 of 11831. Diz o historiado que "se sua [do juiz inquisidor] missão sagrada era cumprida, importava pouco quais métodos foram usados" (tradução livre).
} 
afirmación del nacimiento de un derecho judicial de penar y la solicitud de ejercer este derecho" ${ }^{" 470}$. O direito de punir é do Estado-Juiz presentado pela pessoa do julgador, e é o processo, com seus valores, que separa o juiz da pena. Para o mestre alemão, a exigência do processo é íncita ao Estado de Direito que correlacionou o princípio da "nulla poena sine lege" com o de "nulla poena sine judicio".

Retirar alguns dos poderes do juiz não significa desnudar todos os instrumentos do julgador, que sempre deterá a última palavra do processo: a decisão. Lembramos que Tocqueville, ao entrar em contato com o sistema de justiça americano do século XIX, sustenta que “um juiz americano pode ditar uma decisão apenas quando um litígio ocorre, ele só está familiarizado com casos especiais e não pode agir até que o caso seja devidamente trazido à Corte. Sua posição é, portanto, perfeitamente similar ao de outras nações; e ele é, apesar disso, investido de imenso poder" ${ }^{471}$.

O argumento principal do interesse público é sustentado por ao menos quatro secundários: I) o impulso oficial; II) poder geral de cautela do juiz penal; III) o princípio da obrigatoriedade; IV) o requerimento implícito.

\subsubsection{O impulso oficial}

O impulso oficial "consiste em atribuir ao órgão jurisdicional a ativação que move o procedimento de fase em fase, até a solução definitiva da causa" ${ }^{\text {"472 }}$. O juiz, então, senhor (Herr, na expressão alemã) do processo, deve levá-lo a termo. Se a essência da medida cautelar processual penal é assegurar o processo, o juiz deve dispor deste instrumento independente de provocação, justamente porque é dele o poder-dever da segurança processual. $\mathrm{O}$ argumento do impulso oficial para sustentar a prisão preventiva de ofício está ligado a uma concepção de sistema acusatório em que ao juiz somente é defeso iniciar sem provocação um processo penal. Porém, depois de provocado o juízo (por meio do oferecimento da denúncia), pouco ou nada escapa aos poderes jurisdicionais de

\footnotetext{
${ }^{470}$ GOLDSCHMIDT, J. op. cit. p. 34.

${ }^{471}$ TOCQUEVILLE, A. Democracy in America. V. I. p. 103. Ainda de acordo com Tocqueville, este poder do juiz vinha do fato de que nos Estados Unidos da América o juiz podia (como pode o juiz brasileiro, por meio do controle difuso de constitucionalidade) fundar suas decisões diretamente na Constituição, declarando as leis inconstitucionais. Em outra passagem, diz o mesmo autor: "In England and in America the judges exercise an influence upon criminal trials which the French judges have never possessed." p. 313.

472 "Opõe-se-lhe o critério do impulso das partes, pelo qual o juiz se limita a realizar os atos específicos que estas the solicitam." CINTRA, A.C.A.; GRINOVER, A.P.; DINAMARCO, C.R. Teoria geral do processo. p. 364 .
} 
ofício $^{473}$. Não se verifica mais na doutrina ou na jurisprudência a defesa de uma ação penal de ofício. Contudo, a ideia de que basta o oferecimento e o recebimento da denúncia para se instaurar um processo com plenos poderes de ofício do juiz (o que Damaška chama de "fechar as portas da corte" penetração na doutrina. A legislação infraconstitucional respalda a tese, com a possibilidade de medidas cautelares, de produção probatória e até mesmo o recurso de ofício. Ademais, nos crimes de ação penal pública, o julgador pode proferir sentença condenatória a despeito de "opinião" do Ministério Público pela absolvição (art. 385 do $\mathrm{CPP})^{475}$. Depois da denúncia, a ideia de contenda desaparece e o processo torna-se um affair de deux. Trata-se de um desdobramento dos princípios do "iura novit curia" e da " $d a$ mihi factum, dabo tibi ius".

Parte deste argumento a ideia que prevaleceu na Lei 12.403 de 2011 , de que somente após iniciado o processo penal pode o juiz exercer seu poder de impor medidas cautelares de ofício ${ }^{476}$, como se a separação entre acusador e julgador tivesse plena eficácia apenas antes de oferecida a denúncia ${ }^{477}$. Em realidade, o entendimento do

\footnotetext{
${ }^{473}$ Citamos ilustrativa passagem de Nereu Giacomolli: "No processo penal, fruto dessa concepção de que o juiz é o ser todo-poderoso, o centro do universo processual, representante da ordem instituída, é que continua, apesar da Constituição Federal e dos Diplomas Internacionais, o magistrado, como representante único e dos demais sujeitos processuais, o garantidor da ordem pública, podendo, assim, nessa concepção medieval, decretar a prisão de ofício e para garantir essa ordem, de ir em busca das provas para condenar o acusado, determinar ao Estado-Acusador para que promova o aditamento porque deseja condenar por um fato mais grave daquele descrito na acusação (artigos 383 e 384 do CPP)". GIACOMOLLI, N.J. Exigências e perspectivas do Processo Penal na contemporaneidade. p. 291)

${ }^{474}$ DAMAŠKA, M. The faces... Loc 2297 of 6774.

475 A expressão "tenha opinado" trazida pelo Código de Processo Penal de 1941 é representativa do caráter secundário que cumpria ao Ministério Público na época.

${ }^{476}$ Com as exceções já tratadas, sendo a mais notável a conversão da prisão em flagrante em prisão preventiva do inciso II do art. 310 do Código de Processo Penal com redação dada pela Lei 12.403 de 2011.

${ }^{477}$ Professa neste sentido Marcellus Polastri Lima, in verbis: “Ocorre que, dentro do sistema processual penal brasileiro não haveria incoerência no atuar de ofício, desde que exclusivamente durante a fase processual. (...) Se em se tratando de decretação da prisão de ofício durante o processo, não vemos nenhuma impropriedade, sendo tal atuar consentâneo com a especial característica do processo penal, até porque são dados ao juiz vastos poderes instrutórios durante o processo, consoante se vê do art. 156 do CPP, advindo a Constituição de 1988, a decretação da prisão preventiva de ofício, no caso de investigação penal, passa a ser inconstitucional, em vista do dispositivo do art. 129, I, da CF, pois, agora, em vista do dispositivo constitucional, o magistrado no processo penal, deve se abster de promover atos na investigação da ação penal pública de ofício.

Com a Constituição de 1988 o processo penal assume contornos do sistema acusatório puro, e não haveria compatibilidade desta depuração do sistema com o decreto de prisão preventiva de ofício durante a investigação, quando o magistrado agirá, indevidamente, sem sua necessária imparcialidade. Tal resta evidente em se tratando de inquérito policial, quando nem existe processo e jurisdição.

Assim, aqui é diferente da hipótese de já existir instaurado processo penal, pois, não havendo processo ou jurisdição, a decretação da prisão de ofício equivaleria a um inconstitucional proceder do juízo." LIMA, M.P. Manual de processo penal. p. 651-652. Negritos no original.
} 
sistema acusatório em parte da Europa continental é exatamente o contrário ${ }^{478}$. De acordo com Goldschmidt, desenvolveu-se na ciência processual penal o direito de punir do estado, em detrimento do direito de acusar ${ }^{479}$. Assim, basta o aparecimento de uma querela (ou seja, basta o oferecimento da denúncia), o resto é o direito de punir. E é no direito de punir que se insere a prisão preventiva de ofício, tendo em vista a já mencionada fraude de etiquetas da prisão preventiva.

Como adverte Nereu Giacomolli, a oficialidade não pode se tornar um elemento reacionário que volte o juiz à sua posição de acusador-julgador, que detinha sob a égide da inquisição ${ }^{480}$.

\subsubsection{Poder geral de cautela do juiz penal}

Se for certo que a prisão preventiva consiste em uma medida cautelar (a mais gravosa de todas enumeradas no ordenamento jurídico do Brasil), um consistente argumento que se pode deduzir em favor do poder do juiz de ordenar a prisão preventiva de ofício é o poder geral de cautela dado ao magistrado.

O poder geral de cautela desenvolveu-se no direito processual civil e foi consagrado no art. 798 do Código de Processo Civil ${ }^{481}$. De acordo com Humberto Theodoro Júnior, o poder geral de cautela dá ao juiz a possibilidade de "criar providências de segurança fora dos casos típicos já arrolados pelo Código" ${ }^{„ 482}$. De acordo com Aury Lopes, embasado em Carnelutti, no processo civil "é reconhecido o poder geral de cautela (potere cautelare generale) confiado aos juízes, em virtude do qual eles podem, sempre, onde se manifeste a possibilidade de um dano que deriva do atraso de um procedimento principal, providenciar de modo preventivo a eliminar o perigo, utilizando a forma e o

\footnotetext{
${ }^{478}$ Ver o capítulo 4.1 sobre a Itália. Na Espanha e na França, a fase pré-processual é tradicionalmente regida pelo juiz de instrução, que detinha poderes de ofício para dar cabo à investigação. O desenvolvimento processual penal foi no sentido de isolar a fase processual para que nela vigesse o princípio acusatório.

${ }^{479}$ GOLDSCHMIDT, J. op. cit. p. 32-33.

480 "Porém, o fenômeno da oficialidade do processo penal não abarca a união das atividades dos sujeitos oficiais, sob pena de o sujeito encarregado de proferir uma sentença e de aplicar a sanção ocupar o lugar do Estado-Acusador, transmudando o sujeito, de julgador em acusador-julgador, bem como de concretizar um veredicto inválido (ausência de defesa) quando o sujeito oficial que atua no polo passivo (obrigatoriedade da defesa técnica) unir-se à oficialidade acusatória." (GIACOMOLLI, N.J. Exigências e perspectivas do Processo Penal na contemporaneidade. p. 277.

481 Art. 798. Além dos procedimentos cautelares específicos, que este Código regula no Capítulo II deste Livro, poderá o juiz determinar as medidas provisórias que julgar adequadas, quando houver fundado receio de que uma parte, antes do julgamento da lide, cause ao direito da outra lesão grave e de difícil reparação.

482 THEODORO J.,H. Curso de direito processual civil. p. 557.
} 
meio que considerem oportunos e apropriados ao caso. Significa dizer que o juiz cível possui amplo poder de lançar mão de medidas de cunho acautelatório, mesmo sendo atípicas as medidas, para efetivar a tutela cautelar. Tanto que o processo civil, além das medidas de antecipação da tutela, consagra um rol de medidas cautelares nominadas e a aceitação das medidas inominadas, em nome do poder geral de cautela que confere o art. 798 do CPC.,

Embora haja julgados que concedam o poder geral de cautela ao juiz penal $^{484}$ (aplicando-se por analogia o art. 798 do CPC com base no art. $3^{\circ}$ do CPP), a própria aplicação do instituto ao processo penal é veementemente rechaçada pela doutrina. Para Magalhães Gomes, "em primeiro lugar, não se pode cogitar em matéria criminal de um 'poder geral de cautela', através do qual o juiz possa impor ao acusado restrições não expressamente previstas pelo legislador, como sucede no âmbito da jurisdição civil; tratando-se de limitação de liberdade, é indispensável a expressa permissão legal para tanto, pois o princípio da legalidade dos delitos e das penas não diz respeito apenas ao momento da cominação, mas à 'legalidade da inteira repressão', que põe em jogo a liberdade da pessoa desde os momentos iniciais do processo até a execução da pena impostas" ${ }^{485}$.

Além do poder geral de cautela estar ligado mais especificamente à tipologia das medidas cautelares (agora ampliada com a Lei 12.403/2011, que superou a dualidade da prisão como sendo a única medida cautelar), a medida cautelar no processo penal não pode ser entendida simplesmente como uma garantia geral do processo. Trata-se

\footnotetext{
${ }^{483}$ Op. cit. p. 575.

${ }^{484}$ Art. 798. Além dos procedimentos cautelares específicos, que este Código regula no Capítulo II deste Livro, poderá o juiz determinar as medidas provisórias que julgar adequadas, quando houver fundado receio de que uma parte, antes do julgamento da lide, cause ao direito da outra lesão grave e de difícil reparação. O poder geral de cautela no âmbito penal já foi aplicado pelo Supremo Tribunal Federal quanto à produção antecipada de provas (HC 109728, Relator: Min. RICARDO LEWANDOWSKI, Segunda Turma, julgado em 15/05/2012) e para a aplicação analógica do art. 798 do CPC no caso da retenção de passaporte de réu (HC 101830, Relator(a): Min. LUIZ FUX, Primeira Turma, julgado em 12/04/2011).

${ }^{485}$ GOMES F., A.M. Presunção de inocência e prisão cautelar. p. 57. No mesmo sentido Aury Lopes Jr. "No processo penal, não existem medidas cautelares inominadas e tampouco possui o juiz criminal um poder geral de cautela. No processo penal, forma é garantia. Logo, não há espaço para "poderes gerais", pois todo poder é estritamente vinculado a limites e à forma legal. O processo penal é um instrumento limitador do poder punitivo estatal, de modo que ele somente pode ser exercido e legitimado a partir do estrito respeito às regras do devido processo. E, nesse contexto, o Princípio da Legalidade é fundante de todas as atividades desenvolvidas, posto que o due process of law estrutura-se a partir da legalidade $e$ emana daí seu poder." LOPES J.A. Direito processual penal. p. 575. Negritos no original. Na jurisprudência, pela inexistência de poder geral de cautela ao juiz penal temos HC 222.298/SE, Rel. Ministro JORGE MUSSI, QUINTA TURMA, julgado em 17/10/2013, DJe 30/10/2013.
} 
da garantia de certo fim do processo: a punição do réu. Não há medidas cautelares que garantam a integridade dos direitos do réu contra o Estado. Para isso já estão seus direitos individuais e a presunção de inocência. Temos, no argumento do poder geral de cautela, mais uma vez aquele juiz típico do sistema inquisitório, responsável pelo processo e, em última análise, pela repressão do delito.

Em conclusão, temos que o argumento do poder geral de cautela não pode ser invocado para dar o poder ao juiz de impor uma prisão cautelar ao seu talante, sem requerimento da acusação, com objetivo de acautelar o "bom andamento" do processo (ou seja, garantir a punição do réu).

\subsubsection{O princípio da obrigatoriedade}

O legislador brasileiro, indiretamente por meio do art. 28 do Código de Processo Penal, optou pela adoção do princípio da obrigatoriedade nos crimes de ação penal de iniciativa pública, tipicamente aplicado nas jurisdições da Europa continental. Não há discricionariedade para a iniciativa da ação penal por parte do Ministério Público.

Da obrigatoriedade vem um dos argumentos mais contundentes em favor da possibilidade da prisão preventiva decretada de ofício pelo juiz: se o Ministério Público não tem discricionariedade par acusar, ou seja, acusa sempre que houver o fumus commissi delicti, a punibilidade concreta e a justa causa, não teria tampouco discricionariedade para requerer a prisão preventiva, i.e. deve pedi-la sempre que estiverem presentes os requisitos legais. Prevarica o membro do Ministério Público que, diante dos requisitos, não requer a prisão preventiva. É nessa linha, por exemplo, o argumento de Pacelli e Fischer quando sustentam que a possibilidade de prisão preventiva de ofício "decorre, na ordem jurídica atual, da regra da obrigatoriedade". É por isso que o magistrado pode e deve "exercer em maior extensão o controle da legalidade, não mais da investigação, mas já da efetividade do processo penal. E, para isso, poderá, por iniciativa própria, adotar as medidas cautelares necessárias a tais finalidades, incluindo a prisão",486.

De plano, os defensores de tal argumento devem convir que não poderia haver decretação de ofício de prisão preventiva nos casos de ação penal privada, já que nesta, obviamente, não vigora o princípio da obrigatoriedade.

${ }^{486}$ OLIVEIRA, E.P.; FISCHER, D. Comentários ao Código de Processo Penal. p. 642. 
O problema de tal argumento é o contrassenso de que, levado às últimas consequências, também pode ser aplicado à própria ação penal, e isso não é admitido no direito brasileiro. Mesmo no caso do art. 28 do Código, diante do pedido de arquivamento feito pelo membro do Ministério Público, o juiz não leva adiante a ação penal de ofício, mas fará remessa do inquérito ou peças de informação ao procurador-geral, e este oferecerá a denúncia, designará outro órgão do Ministério Público para oferecê-la, ou insistirá no pedido de arquivamento, ao qual só então estará o juiz obrigado a atender.

De qualquer forma, se o oferecimento da denúncia é obrigatório nos casos mencionados, não significa que a prisão cautelar também o é quando presentes seus requisitos. É o membro do Ministério Público que deve deter a atribuição de, quando achar necessário, provocar o juízo com o requerimento da segregação cautelar.

Ademais, é preciso lembrar que o movimento de reforma dos sistemas processuais penais tem sido acompanhado de uma flexibilização do princípio da obrigatoriedade. Tenta-se superar a desconfiança e o preconceito que causa nos ordenamentos derivados da Europa continental o princípio da oportunidade, que já há muito é praticado nas jurisdições da Common Law. No Chile, após profunda e rigorosa reforma do sistema penal, como se verá no capítulo 4.4, foi implantado o princípio da oportunidade, conferindo ao Ministério Público a decisão sobre a persecução penal, por meio de uma política de atuação discutida tanto internamente quanto com a sociedade civil. Dizem os reformadores chilenos que seu sistema de justiça nunca suportou levar a juízo todas as causas, havendo, mesmo com o princípio da obrigatoriedade, uma "seleção" de causas de modo arbitrário e localizado. Causas sem expressão ou pelas quais não havia interesse deveriam ser alcançadas pela prescrição nos escaninhos da Justiça. Com a reforma, instituiu-se uma forma democrática e transparente de se selecionar causas ${ }^{487}$.

${ }^{487}$ DUCE J., M.; RIEGO R. C. Proceso penal. p. 179 e seguintes. O princípio da oportunidade e seu regramento foram consagrados no novo Código de 2000, no art. 170 com os seguintes dizeres: Artículo 170 . Principio de oportunidad. Los fiscales del ministerio público podrán no iniciar la persecución penal o abandonar la ya iniciada cuando se tratare de un hecho que no comprometiere gravemente el interés público, a menos que la pena mínima asignada al delito excediere la de presidio o reclusión menores en su grado mínimo o que se tratare de un delito cometido por un funcionario público en el ejercicio de sus funciones. Para estos efectos, el fiscal deberá emitir una decisión motivada, la que comunicará al juez de garantía. Éste, a su vez, la notificará a los intervinientes, si los hubiere. Dentro de los diez días siguientes a la comunicación de la decisión del fiscal, el juez, de oficio o a petición de cualquiera de los intervinientes, podrá dejarla sin efecto cuando considerare que aquél ha excedido sus atribuciones en cuanto la pena mínima prevista para el hecho de que se tratare excediere la de presidio o reclusión menores en su grado mínimo, o se tratare de un delito cometido por un funcionario público en el ejercicio de sus funciones. 
Assim também na Espanha, já há autores que defendem a existência da oportunidade naquela jurisdição ${ }^{488}$. O Código de Procedimento Penal da Colômbia de 2004 já abarca a aplicação do princípio da oportunidade ${ }^{489}$.

\subsubsection{O requerimento implícito}

Poder-se-ia dizer que o pedido de condenação deduzido pelo Ministério Público no momento do oferecimento da denúncia já traria consigo o pedido para que todos os meios possíveis sejam empregados para se chegar ao fim. Trata-se de uma "terceirização" da elaboração das estratégias das ações possíveis para se assegurar o fim da punição.

$\mathrm{O}$ argumento é derivado daquele entendimento já mencionado de que no processo acusatório, bastaria o oferecimento da denúncia pela acusação para que o juiz se incumbisse e se responsabilizasse por todo o restante. Inegavelmente, é próprio de um modelo de justiça penal que privilegia a eficácia da política de segurança pública em detrimento das garantias individuais. Conforme coloca Ambos, não seria possível, no processo penal, aplicar a ideia de que a medida cautelar seria uma antecipação da tutela jurisdicional já requerida pelo autor da ação penal na denúncia ${ }^{490}$. Mesmo o Código de Processo Civil dispõe que só em casos excepcionais, expressamente autorizados por lei,

También la dejará sin efecto cuando, dentro del mismo plazo, la víctima manifestare de cualquier modo su interés en el inicio o en la continuación de la persecución penal. La decisión que el juez emitiere em conformidad al inciso anterior obligará al fiscal a continuar con la persecución penal. Una vez vencido el plazo señalado en el inciso tercero o rechazada por el juez la reclamación respectiva, los intervinientes contarán con un plazo de diez días para reclamar de la decisión del fiscal ante las autoridades del ministerio público. Conociendo de esta reclamación, las autoridades del ministerio público deberán verificar si la decisión del fiscal se ajusta a las políticas generales del servicio y a las normas que hubieren sido dictadas al respecto. Transcurrido el plazo previsto en el inciso precedente sin que se hubiere formulado reclamación o rechazada ésta por parte de las autoridades del ministerio público, se entenderá extinguida la acción penal respecto del hecho de que se tratare. La extinción de la acción penal de acuerdo a lo previsto en este artículo no perjudicará en modo alguno el derecho a perseguir por la vía civil las responsabilidades pecuniarias derivadas del mismo hecho.

${ }^{488}$ RODRÍGUEZ V.,M. Discrecionalidad del Ministerio Público y objeto del juicio abreviado. p. 499.

489 Artículo 321. Principio de oportunidad y política criminal. La aplicación del principio de oportunidad deberá hacerse con sujeción a la política criminal del Estado.

Artículo 322. Legalidad. La Fiscalía General de la Nación está obligada a perseguir a los autores y partícipes en los hechos que revistan las características de una conducta punible que llegue a su conocimiento, excepto por la aplicación del principio de oportunidad, en los términos y condiciones previstos en este código.

Artículo 323. Aplicación del principio de oportunidad. Modificado por el art. 1, Ley 1312 de 2009 La Fiscalía General de la Nación podrá suspender, interrumpir o renunciar a la persecución penal, en los casos que establece este código para la aplicación del principio de oportunidad.

${ }^{490}$ AMBOS, K.; CHOUKR, F.H. A reforma do processo penal no Brasil e na América Latina. p. 168 e seguintes. 
determinará o juiz medidas cautelares sem a audiência das partes. Isso parte da ideia civilista segundo a qual a medida cautelar e processo cautelar são institutos distintos ${ }^{491}$.

No mais, o pedido deduzido na denúncia é o da condenação ao final do processo e não durante o processo. Se se pensar que ao Ministério Público já interessa o encarceramento desde o início, voltamos à utilização da medida cautelar como antecipação da pena em expedientes que chamamos de fraude de etiqueta, tratada acima.

\subsection{A representação da polícia como uma provocação suficiente da jurisdição}

De acordo com tal argumento, ligado à tradição policialesca do Código de 1941, em que a fase de inquérito policial era a peça fundamental de um processo, a mera representação da polícia já seria suficiente para que o juiz possa decidir sobre a prisão preventiva, pois, assim, não está agindo de ofício, mas, sim, por provocação. Desta forma, não seria necessário que o ordenamento condicionasse a prisão preventiva a um pedido do Ministério Público, bastando a representação da autoridade policial, como sói acontecer nas já tratadas conversões de flagrante em prisão preventiva.

Em primeiro lugar, a polícia não é parte no processo penal e, por isso, a representação não tem a mesma natureza do pedido da parte. Se o juiz age apenas com base na representação, ainda temos o que Carnelutti chamou de jurisdição sem processo. A Constituição Federal de 1988 delimitou a atribuição da polícia no artigo 144, e dá ao Ministério Público a titularidade da ação penal pública (art. 129, inciso I).

Afastando-se do processo penal as teorias civilistas que entendem como parte legitimada ativa aquela que é "titular do direito subjetivo material demandado", temos que o direito de punir é do Estado (por meio do juiz, como ensina Goldschmidt), e

\footnotetext{
${ }^{491}$ A disposição do CPC se assemelha à do Código de Processo Penal modelo para a Iberoamérica nos atos jurisdicionais introdutórios: Art. 248 Atos jurisdicionais. Quando for urgente a realização de um ato jurisdicional, o oficial encarregado da investigação informará ao Ministério Público, que o requererá ao juiz da instrução; nos casos de extrema urgência, a polícia poderá requerer diretamente o ato ao juiz da instrução com a devida comunicação ao Ministério Público. Ainda, o Art. 258: Atos jurisdicionais: antecipação da prova. Quando for necessário praticar um reconhecimento, uma reconstrução, realizar perícia ou inspeção, que por suas naturezas e características devam ser consideradas atos definitivos $e$ irreproduzíveis, ou quando deva ser colhida uma declaração que, por algum obstáculo difícil de superar, se presuma que não poderá ser prestada durante a audiência de instrução e debates, o Ministério Público ou qualquer um dos intervenientes requererão ao juiz da instrução que realize o ato...
} 
não propriamente do Ministério Público. A este é dada pela lei uma pretensão acusatória, ou seja, "a titularidade ou legitimidade para a propositura da ação penal" ${ }^{, 492}$. Não é o caso da polícia, a quem não é dada tal pretensão acusatória que lhe permita demandar em juízo. No desenho da Constituição de 1988, a polícia atua principalmente por meio do inquérito policial na fase inquisitória do processo. A polícia, além de carecer de legitimidade como condição da ação, não tem capacidade postulatória, o que determina a ausência de um dos pressupostos processuais ${ }^{493}$.

Por fim, para reforçar a ideia de que a representação não pode ser equiparada a um requerimento de parte, diga-se que, no caso de indeferimento da representação, à autoridade processual policial não é dado o interesse recursal ${ }^{494}$.

\subsection{A separação entre as fases "inquisitória" e "acusatória"}

O assunto da conversão da prisão em flagrante em prisão preventiva de ofício pelo juiz antes mesmo de oferecida a denúncia já foi tratado neste trabalho. Contudo, mais um argumento deve ser analisado quanto à validade do dispositivo e que está, também, ligado à impossibilidade de que a polícia provoque a jurisdição.

A insuficiência da representação policial para que atue a jurisdição está ligada às reformas acusatórias, que têm como um dos seus objetivos o deslocamento do centro de gravidade do processo inquisitório (a fase de investigação) para a fase processual propriamente dita. Além disso, não há um processo acusatório autêntico sem uma separação contundente entre esta fase de investigação ou inquisitória - no Brasil, dominada pelo instituto do inquérito policial - e a fase após a apresentação da denúncia. Já se pensou no Brasil que a fase de instrução prévia seria condição sem a qual a fase oral não poderia se desenrolar. O juiz necessitaria de uma base anterior para dar ou retirar credibilidade dos testemunhos, dos documentos etc., e para decidir sem temor nem ansiedade de agir com deficiência $^{495}$. A ideia seria que o juiz se preparasse meticulosamente para a fase acusatória. Como a imparcialidade não é o atributo central de um juiz ativista em uma

\footnotetext{
492 BADARÓ, G.H.R.I. Processo Penal. p. 102 a 104.

493 OLIVEIRA, E.P.; FISCHER, D. Comentários ao Código de Processo Penal e sua jurisprudência. p. 642.

${ }^{494}$ MARCÃO, R. Prisões cautelares, liberdade provisória e medidas cautelares restritivas. P. 138.

495 ALMEIDA, J.C.M. Princípios fundamentais do processo penal. p. 11 e seguintes.
} 
Justiça que busca implementar uma política pública, todas as informações que chegam ao julgador são bem-vindas. O sistema inquisitório repudia um juiz como o estadunidense ou o chileno, que recebe todas as informações relevantes para a decisão em uma audiência com a presença de ambas as partes e sem nenhum conhecimento prévio da causa, uma "mente virgem"496.

$\mathrm{Na}$ fase pós-revolucionária, do acusatório formal ou misto, sabe-se que as reformas liberais que intencionavam isolar a fase do juízo oral não foram tão bemsucedidas em razão do fato de que o clamor pelo interesse público e pela verdade real inflavam a fase inquisitiva do processo. À medida que decisões garantistas tornavam a presença ativa do defensor obrigatória, mais importância era colocada na investigação exaustiva $^{497}$. Ao final, no acusatório misto ou formal a fase de investigação preliminar passou a ser "o procedimento crucial de todo o processo" ${ }^{498}$. Não se pode olvidar que o sistema do inquérito policial sempre esteve ${ }^{499}$, e está no Brasil, estritamente ligado à Inquisição e ao inquisitorialismo.

Por isso, Kai Ambos e Fauzi Choukr sustentam que, “[p]ara percorrer o caminho rumo ao modelo acusatório na sua forma mais comum no cenário contemporâneo, as ideias reformistas partiram de uma estrutura na qual se retirava da Autoridade Policial a possibilidade de requerer medidas cautelares diretamente ao Juiz, passando, necessariamente, pelo Ministério Público, e reservando a instauração do inquérito policial à iniciativa exclusiva do Ministério Público (proprio motu) ou por provocação do ofendido (mas nunca do Juiz ou da própria autoridade policial)." Professam os autores, ainda, que o art. $10, \S 2^{\circ}$, do projeto de Lei 4.209-C de $2001^{500}$

\footnotetext{
${ }^{496} \mathrm{Em}$ um Estado reativo as partes formam uma "energia bipolar em que toda a informação adquirida pelo juiz fora da sala de julgamento vai velar à suspeita de prejulgamento e distorção". DAMAŠKA, M. The faces... Loc. 3505 of 6774. Em outra passagem temos: "If in the conflict-solving process the decision is to emerge from the dialectic of party debate, ideally the decision maker must enter the case unprepared, unaware of all matters specifically related to the issues. He should have a "virgin mind", to be tutored only through the bilateral process of evidentiary presentation and argument. The desirability of ignorance, of course, does not entail the desiranility of ineptitude: the decision maker should be mentally agile, able deftly to manipulate and make sense of the data presented to him. In sum, the judicial tabula rasa must be skillful, intelligent, and wise." (Loc 2861 of 6774).

${ }^{497}$ DAMAŠKA, M. The faces... Loc 3942 of 6774 . "At trial, information from the investigation continued to exert a strong influence on decision making, notwithstanding protests of academnic commentators."

498 Idem. Ibidem.

${ }^{499}$ FOUCAULT, M. A verdade e as formas jurídicas. p. 70 e seguintes.

${ }^{500}$ Projeto elaborado pela comissão de juristas presidida pela Professora Ada Pelegrini Grinover que tratou especificamente do inquérito policial. $\mathrm{O}$ parágrafo $2^{\circ}$ do art. 10 do projeto tem a seguinte redação: " $\$ 2^{\circ} \mathrm{As}$ 
significaria que "a decantada acusatoriedade no figurino constitucional continua sendo olvidada legislativamente" e seguem: "o relacionamento inquisitivo e direto entre Polícia Judiciária, nos mesmo moldes autoritários de 1942 continua a plenos pulmões na vida prática brasileira" ${ }^{901}$. No Brasil houve até mesmo quem sustentasse a necessidade do fim do inquérito policial como um golpe decisivo contra a estrutura inquisitória ${ }^{502}$.

Entretanto, o atual sistema processual pátrio segue promovendo a mistura entre as duas fases. $\mathrm{O}$ art. 155 do Código, com sua nova redação dada pela Lei 11.690 de 2008, é um dos exemplos. O juiz não pode formar sua conviç̧ão somente com base nos elementos do inquérito, o que significa, contrario sensu, que o juiz está autorizado a formar uma condenação com base em elementos do inquérito. Outro exemplo do "elo promíscuo" entre as fases de investigação e acusatória é a conversão da prisão em flagrante em preventiva. Por prevenção ${ }^{503}$, o juiz conhece da causa quando nem mesmo foi oferecida a denúncia, decide de ofício sobre a prisão preventiva e, após, julga a causa.

Essa discussão é cara ao processo penal italiano, no qual, por exemplo, foi implementada a regra dos autos duplos (doppio fascicolo) do Código de 1988, que intencionava, justamente, a separação radical entre investigação e processo ${ }^{504}$. $\mathrm{Na}$ Itália do novo Código, entende-se que o juiz que dará a sentença não pode ser "contaminado" pelos elementos da fase inquisitória. Os autos são separados e os autos da fase investigativa ficam disponíveis somente às partes. Podem ser usados para desafiar a credibilidade da testemunha em juízo, mas o juiz não os pode utilizar para a condenação. Conforme coloca Illuminati em relação à Itália, um dos principais marcos da implementação do sistema acusatório no país foi a separação clara entre as fases inquisitiva (inquérito, no caso do

diligências que dependerem de autorização judicial serão requeridas ao juiz competente pelo Ministério Público, autoridade policial, ofendido, investigado ou indiciado."

${ }^{501}$ AMBOS, K.; CHOUKR, F.H. A reforma do processo penal no Brasil e na América Latina. p. 37.

${ }^{502}$ COUTINHO, J.N.M. O papel do novo juiz no processo penal. p. 40 e seguintes.

503 Ressalvamos o caso do Tribunal de Justiça de São Paulo que, apenas na capital, implantou um Departamento de Inquéritos Policiais (DIPO) com juízes que conhecem dos casos relacionados à judicialização de questões relacionadas ao inquérito policial bem como o recebimento dos autos de prisões em flagrante. Mesmo na capital há duas exceções em que o juízo que recebe o auto de prisão em flagrante já se tornará prevento para julgar a causa: nos casos de violência doméstica contra a mulher e nos delitos de competência do Tribunal do Júri.

${ }^{504} \mathrm{O}$ movimento de reforma italiano se intensificou após a mudança constitucional de 1999 que reintroduziu o que, segundo Panzavolta, constitui um dos pilares do sistema acusatório: a regra segundo a qual o testemunho do policial sobre o quanto apurado na investigação estava proibido (art. 195/4 do CPP de 1988 com redação dada pela Lei 63/2001). Esta ideia foi reforçada pela decisão 439 de 2000 e 32 e 36 de 2002 da Corte Constitucional. PANZAVOLTA, M. Reforms and counter-reforms in the Italian struggle for an accusatorial criminal law system. p. 612. 
Brasil) e acusatória. O que foi apurado sem o contraditório não pode ser utilizado - a não ser em casos excepcionais - na fase do acusatório contraditório ${ }^{505}$.

O tema é relevante não só na Itália como em toda a Europa. Como colocam Gimeno e Diaz, "[h] oy esta nota del principio acusatorio [separação total entre a fase de instrução e do juízo oral] se encuentra implícitamente consagrada em el 6.1 del CEDH (Convenio Europeo de Derechos Humanos), que, conforme a la interpretación jurisprudencial efectuada por el TEDH (Tribunal Europeo de Derechos Humanos), el derecho a ser juzgado por "un tribunal independiente e imparcial" conlleva la prohibición de que, en las infracciones graves, no sólo el juez instructor pueda entender del juicio y pronunciar la sentencia, sino la necesidad de que ningún magistrado o miembro del M.P. Que haya realizado funciones instructoras pueda formar parte siquiera del Tribunal sentenciador, ${ }^{, 506}$.

\subsection{A inércia da jurisdição}

A decisão sobre a prisão preventiva é jurisdicional e, como tal, deve estar submetida à máxima da ne procedat iudex ex officio, tão importante para o sistema acusatório $^{507}$. Alguns entendem, como já foi mencionado, que a inércia da jurisdição não passa do oferecimento da denúncia, tese que não acolhemos no presente trabalho ${ }^{508}$. O juiz não é parte no processo ${ }^{509}$, e por tal razão, não tem interesse processual ${ }^{510}$. É necessário

\footnotetext{
${ }^{505}$ ILLUMINATI, G. The accusatorial process from the Italian point of view. p. 311/312.

${ }^{506}$ GIMENO S., J.V.; DÍAZ M., M. La prisión provisional y sus medidas alternativas. p. 269.

${ }^{507}$ Interessante notar que ao comentar um traço comum da jurisdição na maioria dos países no século XIX, Tocqueville coloca o Poder Judiciário é inábil para agir sem provocação e que "[a] judicial functionary who should open proceedings, and usurp the censorship of the laws, would in some measure do violence to the passive nature of his authority." TOCQUEVILLE, A. Democracy in America. p. 102.

${ }_{508}$ Esta parece ter sido a intenção do próprio Francisco Campos quando proclamou que o projeto de Código que viria a se transformar no CPP atendia ao princípio do ne procedat iudex ex officio, conforme expõe em suas exposições de motivos.

${ }^{509}$ De acordo com Dinamarco, um conceito puramente processual de parte seria "sujeitos interessados da relação processual, ou os sujeitos do contraditório instituído perante o juiz (Liebman). Dizem-se interessados porque ali estão sempre em defesa de alguma pretensão própria ou alheia, em preparação para receberem o provimento final do processo. Elas participam dos combates inerentes a este e beneficiar-se-ão com os seus efeitos substanciais diretos ou indiretos, ou os suportarão: a tutela jurisdicional a ser concedida endereçar-se-á a uma das partes, impondo-se à outra o sacrifício de uma pretensão (parte vencedora e parte vencida). Nisso elas se diferenciam do juiz, que é estranho ao conflito, paira sobre ele e, nessa condição, é um sujeito desinteressado. O juiz é um sujeito processual sem ser parte. Não sendo parte, é terceiro (até porque, se fosse parte na causa, estaria impedido de oficiar como juiz CPC, art. 134, inc. I)". DINAMARCO, C.R. Instituições de Direito Processual Civil. volume II. p. 246 a 247.
} 
lembrar a célebre frase de Carnelutti para distinguir partes e juízes: "partes nascuntur, judices fiunt" (partes nascem, juízes se fazem). A parte é detentora de um interesse e, por tal motivo, a ela é dado um poder ("nunca vice-versa", diz Carnelutti ${ }^{511}$ ). O contrário só poderia ser concebido no caso do Ministério Público, segue Carnelutti, para quem o interesse nasce do poder (daí porque dizia que o Ministério Público é uma parte ao revés ou uma parte artificial ${ }^{512}$. Do poder do juiz não nasce um interesse para que o processo termine de uma maneira ou de outra.

Na linha de Goldschmidt, Aury Lopes Jr. coloca que "no modelo acusatório, o juiz se limita a decidir, deixando a interposição de solicitações e o recolhimento do material àqueles que perseguem interesses opostos, isto é, às partes. $O$ procedimento penal se converte desse modo em um litígio, e o exame do processado não tem outro significado que o de outorgar audiência. Parte do enfoque de que a melhor forma de averiguar a verdade e realizar-se a justiça é deixar a invocação jurisdicional e a coleta do material probatório àqueles que perseguem interesses opostos e sustem opiniões divergentes. Deve-se descarregar o juiz de atividades inerentes às partes, para assegurar sua imparcialidade. Com isso, também se manifesta respeito pela integridade do processado como cidadão",513.

A concepção acusatória, com seu postulado de separação entre julgador e acusador, retira do juízo a iniciativa, conservando-lhe o poder dever de julgar. Não há motivo para que a decretação da segregação cautelar seja uma exceção à regra. Trata-se do

\footnotetext{
${ }^{510}$ Consigna-se aqui que Joaquim Canuto Mendes de Almeida diferenciava o interesse pessoal, dispositivo, do interesse impessoal, nos seguintes termos: "Deve-se, antes de tudo, atender a preliminar distinção.

Assim como - por um lado - os disputantes de satisfação a interesse pessoal (tutelado - qual se revela - por normas consequentemente de direito objetivo privado) dispõem do direito subjetivo questionado, civil ou comercial, principalmente, assim também dispõem eles, em conjunto, dos interesses processuais de agir e de contestar, que regem o impulso e marcam o conteúdo das operações jurisdicionais.

Assim como - por outro lado - os disputantes de satisfação a interesse impessoal (como é o interesse penal, tutelado - qual se ostenta - por norma consequentemente de direito objetivo público) não dispõem do direito subjetivo questionado, porque direito de cada um e de todos, assim também não dispõe eles dos interesses processuais, de acusar e de defender, os quais assomam regidos - quanto ao respectivo impulso - e marcados - quanto ao respectivo contúdo - pelo poder-dever de espontaneidade jurisdicional." Princípios fundamentais do processo penal. p. XX e XXI.

${ }^{511}$ CARNELUTTI, F. Cuestiones sobre el proceso penal. p. 212 e seguintes.

512 Carnelutti acreditava que o processo penal não era dispositivo, mas voluntário, com uma parte "fabricada" que "caminha se separando do juiz no sentido da parte".

${ }^{513}$ LOPES J. A. Direito processual penal. p. 73.
} 
princípio da demanda das medidas cautelares penais, já consagrado no direito italiano ("principio della domanda cautelare") ${ }^{514}$.

Tourinho, por exemplo, utiliza a ideia de Carnelutti, sustentando que a prisão preventiva decretada de ofício é "um caso singular de jurisdição sem ação, uma vez que o Juiz, assim agindo, estará instaurando um processo cautelar sem se provocado. Ademais, já é hora de o legislador se conscientizar de que a função do Juiz é dirimir a contenda jus puniendi versus jus libertatis. Os atos probatórios, e inclusive as medidas cautelares pessoais ou reais, devem ficar sujeitos aos pedidos das partes, cabendo ao Juiz deferi-los ou não; jamais decretá-los de ofício, como se fosse parte ${ }^{„ 515}$.

Ressalvamos que há entendimentos (já mencionados neste trabalho) que colocam o juiz como o senhor do processo e responsável pelo seu apropriado desenrolar. Se a prisão preventiva configura-se como uma medida cautelar para assegurar o processo, o juiz deve dispor de tal medida. Tornamos a lembrar a figura do juiz como agente de política pública à qual a concepção de 1941 está ligada. Mesmo quando foi concebido o Código do Estado Novo, a regra era que o processo fosse iniciado pelo Ministério Público. No entanto, o juiz poderia condenar mesmo com a discordância do membro do Parquet e "não é consagrada a irrestrita proibição do julgamento ultra petita", como disse Francisco Campos na exposição de motivos. Em oposição à ideologia inquisitória, aplicase ao caso um dos institutos mais relevantes do sistema acusatório, que é a correlação entre acusação e sentença, que pode ser adaptado, no caso da prisão preventiva, para a correlação geral entre o pedido e a decisão (ver capítulo 1.1.2.3). A decisão que decreta a prisão preventiva sem o requerimento do acusador é essencialmente extra petita.

\subsection{O reflexo da prisão preventiva decretada de ofício na imparcialidade do julgador}

\footnotetext{
514 “In tema di misure cautelare, il princípio della 'domanda cautelare', in base al quale Il giudice procede solo su richiesta del pubblico ministero, così come non richiede che quest'ultima, oltre agli elementi su cui essa si fonda ed a quelli a favore dell'indagato, contenga anche l'indicazione dei 'pericula' in relazione ai quali possano ravvisarsi le esigenze cautelari, allo stesso modo non impedisce al giudice di valutare, a prescindere dagli specifici contenuti della richiesta, la sussistenza dei relativi presupposti, ivi comprese le esigenze cautelari”. Cass. Pen., sez. II, sent. 6525 del 21 novembre 2006, citada em BERRI, G. Formulario delle misure cautelari personali e reali. P. 158. Ver capítulo 4.1.

${ }_{515}$ TOURINHO F., F.C. Processo penal. volume 3. p. 547.
} 
No capítulo 1.1.2.1 do presente trabalho procurou-se expor a especial relevância que a imparcialidade do julgador tem no sistema acusatório. Como coloca Damaška, a imparcialidade não é o atributo central de um juiz ativista em um Estado implementador de política, mas, sim seu conhecimento do Direito e sua capacidade de fazer justiça ${ }^{516}$.

Como foi colocado no capítulo citado, a ideia de um juiz totalmente imparcial é quimérica ${ }^{517}$, mas a conclusão a que se chega a partir desta afirmação não é propriamente que alcançar a imparcialidade é impossível, mas, na verdade, a percepcção do incentivo de fomentar critérios objetivos, ancorados no contraditório e no devido processo legal, afastando a tomada de decisão do modo inquisitório.

O juiz que age de ofício, principalmente nas etapas iniciais do processo como é o caso da decisão sobre a prisão preventiva -, já está construindo ${ }^{518}$ sua convicção de condenação a despeito de garantias processuais como o contraditório e a ampla defesa $^{519}$. Como foi colocado no capítulo 1.1.2.1, a partir da teoria da imparcialidade objetiva da Corte Europeia de Direitos Humanos, o juiz, além de ser imparcial, deve parecer imparcial (teoria da aparência). Trata-se justamente da ideia de Damaška, de que os contendores devem esperar o juízo como um ambiente em que se garanta a imparcialidade, um âmbito em que são evitados (através das regras processuais, as regras do jogo) prejulgamentos e preconceitos.

Por isso, a medida cautelar penal deve ser embasada em fatores objetivos valoráveis, i.e. carece de constitucionalidade qualquer fundamentação alcançável apenas

\footnotetext{
${ }^{516}$ DAMA ̌́KA, M. The faces... Loc 3508 of 6774.

517 Para Jacinto Coutinho, "é preciso que fique claro que não há imparcialidade, neutralidade e, de consequência, perfeição na figura do juiz, que é um homem normal e, como todos os outros, sujeito à história de sua sociedade e à sua própria história". COUTINHO, J.N.M. O papel do novo juiz no processo penal. p. 15.

${ }^{518}$ Hassemer propõe um entendimento dinâmico sobre a parcialidade: o juiz se torna cada vez mais parcial à medida que cresce sua convicção sobre a culpabilidade do acusado. HASSEMER, W. Introdução aos fundamentos do Direito Penal. p. 223.

519 "Sempre que o juiz age, de ofício, no sentido de decretar uma prisão, queira-se ou não, ele está manifestando propensão de julgar procedente a acusação e está, de certa forma, mostrando posicionamento contrário ao da pessoa acusada. Pior ainda quando, apesar de manifestação contrária do promotor de justiça, o juiz decreta a prisão. " FERNANDES, A.S. Funções e limites da prisão processual. p. 5.
} 
pela subjetividade do julgador ou conhecimentos extraprocessuais. O requerimento da parte seria o primeiro desses fatores objetivos ${ }^{520}$.

Esta concepção aniquila a decretação de ofício da prisão preventiva, já que um juiz que toma decisões sem ser provocado, no mínimo, pode ter sua imparcialidade eclipsada. No entanto, é compreensível que esta ideia seja de difícil penetração em terras brasileiras. Na linha do sistema de justiça implementador de uma política de segurança pública, o brasileiro deve esperar um juiz mais ativo no sentido paternalista, que se imponha ativamente e resolva o problema que aflige a segurança. A ideia da teoria da aparência, embora correspondente e adequada ao sistema constitucional de 88 , encontra mais terreno em sociedades como a europeia, em que o liberalismo e a autonomia do indivíduo se coadunam com uma sociedade democrática já desenvolvida. Mas este não é motivo suficiente para que ainda conservemos a atividade de ofício no caso das medidas cautelares no Brasil.

\subsection{Argumento do esvaziamento do contraditório}

As garantias do juiz imparcial e do contraditório são interligadas e interdependentes. Também já se discorreu sobre a relação estreita entre o contraditório e o sistema acusatório (capítulo 1.1.2.2) ${ }^{521}$.

O sistema inquisitório entende suficiente que o julgador tome decisões conhecendo os fatos, sem conferir relevância ao modo pelo qual tais fatos chegaram ao conhecimento do juiz. Trata-se de uma concepção típica de um sistema que diminui a importância da dialeticidade e da própria atividade das partes, que são eclipsadas pela figura onipotente do juiz. Não se ignora que há posições doutrinárias que colocam a atividade de ofício do juiz como um estímulo ao contraditório. Porém pode-se pensar que o terreno conquistado pelo juiz é o mesmo arrebatado das partes, em um jogo de soma zero $^{522}$. O resultado é aquele que vemos, por exemplo, no já mencionado documentário

\footnotetext{
${ }^{520}$ Argumento concebido por Maciá Gomez e Roig Altozano. MACIÁ G., R.; ROIG A., M. El nuevo sistema de adopción de la medida cautelar de la prisión provisional. p. 76 e seguintes.

${ }^{521}$ Ver, por exemplo, ILLUMINATI, G. The accusatorial process from the Italian point of view. p. 299.

${ }^{522}$ Como coloca Damaška, "...if it not a zero-sum, there is certainly an inverse relation between the activity of the parties and that of officials in charge of the legal process". DAMAŠKA, M. The faces... Loc 2797 of 6774.
} 
"Justiça": um juiz que se encarrega de tudo (inclusive o de sugerir o que as partes devem fazer) e partes (principalmente o Ministério Público) que se acomodam na posição de meros colaboradores eventuais do juiz ${ }^{523}$.

Se o ativismo do juiz já é danoso mesmo no ambiente de uma audiência, com ambas as partes presentes, ainda mais pernicioso para os valores fundamentais do processo é o ato do juiz burocrático, escritural (ver item 1.2.4) e solitário da decretação de ofício da prisão preventiva ${ }^{524}$. Para tal decisão - cujos efeitos práticos se assemelham à pior sorte do réu no processo penal: o encarceramento -, o contraditório não pode ser dispensável. Tanto na Espanha como no moderno sistema chileno, as medidas cautelares passaram a ser decididas em audiência, com a presença de ambas as partes em regra ${ }^{525}$, com um juiz que nada sabe previamente sobre a causa. Trata-se de pequenos juízos orais em que a discussão das partes gira em torno da necessidade ou não, e da modalidade, de medida cautelar. O juiz somente pode decidir exposto a tal contraditório.

Partindo deste pressuposto, não resta dúvida que a atividade de ofício do juiz minimiza o contraditório e, no caso da decretação de ofício da prisão preventiva, o aniquila completamente.

\footnotetext{
${ }^{523}$ Parte desta circunstância o argumento de que não haveria qualquer vício se a decretação da prisão preventiva de ofício pelo juiz fosse corroborada pelo membro do Ministério Público. Trata-se da minimização da acusação - Goldschmidt já disse que a ciência processual penal não logrou fazer desenvolver o direito de acusar tanto quanto o direito de punir - que se configura em um mero auxiliar ou referendador dos atos do juiz, em um discurso de dominação e não colaborativo.

${ }^{524}$ É necessário mencionar que Joaquim Canuto Mendes de Almeida diferenciava contraditório dispositivo verdade das partes, (segundo o professor mais afeito ao juízo cível) e o contraditório indispositivo, verdade do juiz, no juízo penal. ALMEIDA, Joaquim Canuto Mendes de. Princípios fundamentais do processo penal. p. XX. No entanto, torna-se difícil admitir um contraditório indispositivo após a entrada em vigor da Constituição de 1988.

525 Evidentemente ressalvam-se as exceções em que a ciência da parte contrária poderia frustrar absolutamente a medida, como, por exemplo, a escuta telefônica. No entanto, estes são casos excepcionais que não podem condicionar a regra do contraditório e da ampla defesa.
} 


\section{NOTAS SOBRE A PRISÃo CAUTELAR DE OFÍCIO NO DIREITO COMPARADO}

O direito fundamental à liberdade, à presunção de inocência e ao devido processo legal são características comuns à maioria dos ordenamentos jurídicos ocidentais e sua vulneração tem problemas semelhantes. As experiências de reformas e contrarreforma por que passam os países do Civil Law enriquecem a análise da forma com a qual as garantias do due process sejam efetivadas da forma mais completa possível.

A partir desta afirmação, passaremos a mencionar alguns aspectos dos ordenamentos externos, sempre com a cautela de não pretender a importação acrítica de institutos. As formas de administração da justiça nos vários Estados é marcadamente diferente mesmo entre aqueles filiados à tradição continental ${ }^{526}$, de forma que os requisitos mínimos para um devido processo legal podem variar de país para país ${ }^{527}$.

Porém, com todas as ressalvas a respeito do estudo do direito comparado, é preciso lembrar que foi o Instituto de Derecho Comparado da Universidad de Córdoba que primeiro fomentou os estudos que ficaram como germens de toda a reforma do processo penal na América Latina ${ }^{528}$.

Ademais, o movimento de internacionalização dos direitos humanos submete vários Estados aos mesmos regramentos internacionais, já mencionados no capítulo 2.3, como a Declaração Universal, de 1948, o Pacto Internacional dos Direitos Civis e Políticos e o Pacto Internacional dos Direitos Econômicos, Sociais e Culturais, de 1966, e a Convenção Americana de Direitos Humanos, de 1969.

Por fim, a análise de outros ordenamentos é necessária porque este já foi um argumento para que se mantenha a prisão preventiva decretada de ofício no Brasil ${ }^{529}$.

\footnotetext{
526 "The range of diversity is such that it eludes expression in terms of a common vocabulary and makes us uncertain about the adequacy of our basic points of reference". DAMAŠKA, M. The faces... Loc 114 of 6774.

${ }^{527}$ Damaška aponta que em virtualmente todos os países impera a ideia de que o juiz deve ser independente e que o acusado deve ser presumido inocente até que se prove o contrário Op.cit. Loc 125 of 6774.

${ }^{528}$ STRUENSEE, E.; MAIER, J.B. J. Introdución in Las reformas. p. 25.

${ }^{529}$ Citamos como exemplo Pacelli de Oliveira e Douglas Fischer que, após sustentarem a validade da prisão preventiva decretada de ofício, dizem: "sobre o tema, não se tem notícia de experiências relevantes no direito comparado em sentido contrário, sobretudo em países que se afirmam inseridos em modelos e sistemas de natureza acusatória, como é o caso, por exemplo, de Portugal, mais alinhado com as práticas
} 
Sendo impossível a análise de todos os ordenamentos, escolhemos apenas quatro deles, de acordo com o critério da influência que exerceram sobre o direito pátrio (como Portugal, Espanha e Itália), e pelo protagonismo na implementação de reformas (como o Chile). Decidiu-se por não acrescentar a Argentina, apesar da proximidade com o Brasil e do processo de reforma lá implementado, tendo em vista a pluralidade de sistemas processuais penais, já que cada província tem um Código Processual Penal e cada uma ${ }^{530}$ está atualmente em um estágio diferente da implantação de um sistema acusatório.

\subsection{Itália}

A Itália, berço do processo penal inquisitório, teve um desenvolvimento sui generis em virtude da dispersão do poder antes da unificação. O procedimento acusatório de origem bárbara chegou a sobreviver, mas o procedimento inquisitório ex officio se sobrepôs, com o segredo e a escrituração ${ }^{531}$.

No sistema inquisitório italiano a prisão preventiva dependia do arbítrio do juiz que o impunha de acordo com "a qualidade de pessoa e a gravidade do delito" 532 , embora já se utilizasse da liberdade perante caução ou juramento.

Como a maioria dos sistemas processuais penais da Europa continental, o da Itália foi fortemente influenciado pela codificação napoleônica de 1808, com o Code d'Instruction Criminelle. Os códigos italianos de 1865, 1913 e o Código Fascista de 1930 (que "ia ao encontro do regime de forma perfeita",533) ainda davam papel preponderante para o juiz instrutor. O Código fascista de 1930 - ou Código Rocco, em homenagem ao ideólogo fascista e ministro da justiça de Mussolini Alfredo Rocco -, cuja estrutura básica

nacionais." OLIVEIRA, E.P.; FISCHER, D. Comentários ao Código de Processo Penal e sua jurisprudência. p. 642 .

${ }^{530} \mathrm{O}$ direito penal tem legislação federal e única para toda a nação (Constituição, art. 75 inciso 12), mas o Direito Processual “(leyes de organización judicial y códigos de procedimiento) es, em principio, parte de La competência legislativa local, esto es, de lós parlamentos provinciales o Del Congreso de La Nación, em su función de legislatura local para atender al servicio judicial en los casos de competencia federal (CN, 116 y 117)". MAIER, J.B. op. cit. p. 76.

${ }^{531}$ MAIER, J.B. op. cit. p. 323 e seguintes.

${ }^{532}$ Idem. Ibidem. p. 327-328.

${ }^{533}$ ILLUMINATI, G. Op.cit. p. 306. 
não foi modificada até 1988, aumentava sobremaneira os poderes do acusador e menoscabava a liberdade individual e o direito de defesa, apenas compilando o modelo misto da legislação anterior de 1913 e $1865^{534}$.

Após a Segunda Guerra Mundial (1939-1945), a Itália passou por um processo de redemocratização que culminou na edição da Constituição de 1948 que, no processo penal, teve o objetivo de dar mais relevância à fase acusatória do processo, eliminando o juiz instrutor ${ }^{535}$. Em 1988, um novo Código de Processo Penal foi editado, transformando totalmente a estrutura no processo penal na Itália, afastando a velha tradição inquisitorial, e caminhando em direção a um modelo adversarial ${ }^{536}$.

A mudança para um sistema acusatório não foi bem recebida pelos juízes, familiarizados com o sistema antigo inquisitório. O Código de 1988 encontrou mais objeções da Corte Constitucional que o anterior código fascista em toda sua vigência ${ }^{537}$. O período de 1992 a $1997^{538}$ foi de contrarreforma na Itália ${ }^{539}$. O esforço de cortar os vínculos com o sistema inquisitório dos idealizadores do Código de 1988 foi parcialmente revertido. $\mathrm{O}$ ápice da contrarreforma foi a decisão da Corte de Cassação que permitia que o juiz introduzisse provas não requeridas pelas partes, algo que o art. 507 do Código de 1988 intencionava restringir ${ }^{540}$. Instalou-se, então, um antagonismo entre a jurisprudência da Corte Constitucional (mais conservadora e que chegou a reabilitar o uso dos elementos da fase inquisitiva) e o Parlamento della Repubblica ${ }^{541}$, que, em 1999, reformou o artigo 111 da Constituição, introduzindo os princípios do processo justo e o princípio da confrontação das partes (Lei constitucional n. 2 de 1999, chamada de "riforma del giusto processo"). De acordo com a nova redação, “a jurisdição atua mediante um processo justo, regulado pela lei", e "todo processo se desenvolve pelo contraditório entre as partes, em condição de paridade, perante um juízo independente e imparcial" ${ }^{542}$.

\footnotetext{
${ }^{534}$ PAZAVOLTA, M. Op.cit. p. 579.

${ }^{535}$ ILLUMINATI, G. Op.cit. p. 307.

${ }^{536}$ PAZAVOLTA, M. Op.cit. p. 578.

${ }^{537}$ ILLUMINATI, G. Op.cit. p. 308.

5381992 foi o ano em que a Máfia entrou em aberto conflito com o Estado. Giovanni Falcone foi morto em 23 de maio e Paolo Borsellino foi morto em 19 de Julho.

539 PAZAVOLTA, M. Op.cit. p. 596.

${ }^{540}$ Cass. Sex. un., 6 nov. 1992 Martin, Cass. Pen. 1993, 280.

${ }^{541}$ PAZAVOLTA, M. Op.cit. p. 603.

${ }^{542}$ Articolo $111 \mathrm{La}$ giurisdizione si attua mediante il giusto processo regolato dalla legge. Ogni processo si svolge nel contraddittorio tra le parti, in condizioni di parità, davanti a giudice terzo e imparziale...
} 
Conforme a escolha metodológica de Illuminati, o Código de 1988 define o sistema acusatório italiano como sendo o sistema em que, em oposição ao sistema inquisitivo, somente a prova produzida em um julgamento público e que garanta o crossexamination pode servir de base para a decisão judicial ${ }^{543}$. A prova só serve ao juízo se advier da confrontação das partes "cada uma tentando persuadir o juiz de seu próprio ponto de vista" ${ }^{, 544}$. A oralidade e a imediação também foram implementadas, ou seja, o juiz deve saber tudo diretamente na hora do julgamento e não através de intermediações.

Outra das características marcantes do sistema acusatório após o novo código italiano é a separação mais aprofundada entre os labores de julgar e acusar "que é essencial para a implementação do princípio do contraditório das partes". De acordo com Illuminati, "um processo justo requer que o juiz mantenha-se equidistante das partes", ou seja, o juiz não pode nem elaborar hipóteses de culpa nem coletar provas que possam fundamentá-la.

Illuminati ainda pontua que o juiz pode ter papel ativo, mas isso não deve minar sua imparcialidade e independência. O juiz, no processo italiano, pode fazer perguntas para as testemunhas depois das partes e pode introduzir provas quando isso for absolutamente necessário ao final do julgamento, mas, para evitar o favorecimento de uma ou outra parte, isso deve ser feito pelo juiz com extrema cautela, e apenas para integrar o direito à prova das partes. Entretanto, alerta Illuminati, “se o juiz substitui uma das partes (em particular o promotor público, que arrisca perder a demanda caso ele não satisfaça o ônus da prova), ele trai sua função e se transforma em um inquisidor ${ }^{, 545}$.

É inegável que o método italiano de 1988, embora tenha suas características próprias (o princípio da obrigatoriedade segue em plena vigência, podendo o juiz condenar o réu por tipo diverso da acusação ou quando o Ministério Público pede absolvição), deveu sua inspiração à técnica do cross-examination no sistema anglosaxão ${ }^{546}$.

As medidas cautelares pessoais no Código de 1988 são divididas entre medidas cautelares propriamente ditas e medidas pré-cautelares (assim chamadas porque

\footnotetext{
${ }^{543}$ ILLUMINATI, G. Op.cit. p. 309.

${ }^{544}$ Idem. Ibidem. p. 310.

${ }^{545}$ Idem. Ibidem. p. 315/316.

${ }^{546}$ PAZAVOLTA, M. Op.cit. p. 596. No mesmo sentido DAMAŠKA, M. Aspectos globales...
} 
ocorrem antes da avaliação jurisdicional, como o arresto e o fermo, dos artigos 379 a 391). As medidas cautelares pessoais coercitivas (que incidem sobre a liberdade física e de locomoção do acusado) estão nos artigos 280 a 286, e podem ser ordenadas apenas pelo juiz após requerimento do Ministério Público.

Na Itália após 1988, o juiz passou a ser o único legitimado a decretar uma medida cautelar ${ }^{547}$, e o Ministério Público o único legitimado a requerê-la ${ }^{548}$. A intenção foi adequar o mecanismo de tomada de decisões cautelares penais à dialética acusatória, como explica Franco Cordero ${ }^{549}$. Vige o princípio da demanda cautelar (“domanda cautelare"), ou seja, nenhuma medida cautelar pode ser levada a cabo sem o requerimento do Ministério Público, de acordo com o art. 291550. Cordero é claro dizendo que: “il provvedimento ex officio nasce nullo" ${ }^{, 551}$.

Após a prisão em flagrante, ou após o fermo, o Ministério Público, se não ordenar a imediata soltura, deve requerer a validação da prisão ao juiz dentro de 48 horas. Se não o fizer, a prisão ou o fermo tornam-se ineficazes ${ }^{552}$. Nesta udienza di convalida o

\footnotetext{
${ }^{547}$ No sistema do Código de 1930, o rito sumário permitia o arresto e a captura (catture) ordenados pelo Ministério Público, que também era chamado para convalidar o arresto e o fermo. CORDERO, F. Procedura Penale. p. 513.

548 "La norma [art. 291, primo comma] ci ricorda come è solo su richiesta del P.M. che si possono adottare misure cautelari, mentre il giudice è il soggeto decidente ma non ex officio.

549 "L'art. 291 adegua i meccanismi alla dialettica accusatori: sono un monopolio giurisdizionale gli interventi cautelari, perché toccano i diritti delle persone variamente esposte al processo; ma altretantto esclusivamente, l'impulso appartiene al pubblico ministero". CORDERO, F. Op.cit. p. 513-514.

${ }^{550}$ Art. 291. 1. Le misure sono disposte su richiesta del pubblico ministero, che presenta al giudice competente gli elementi su cui la richiesta si fonda, nonché tutti gli elementi a favore dell'imputato e le eventuali deduzioni e memorie difensive già depositate. Citamos também a seguinte decisão da Corte de Cassação Penal: "In tema di misure cautelare, il princípio della 'domanda cautelare', in base al quale Il giudice procede solo su richiesta del pubblico ministero, così come non richiede che quest'ultima, oltre agli elementi su cui essa si fonda ed a quelli a favore dell'indagato, contenga anche l'indicazione dei 'pericula' in relazione ai quali possano ravvisarsi le esigenze cautelari, allo stesso modo non impedisce al giudice di valutare, a prescindere dagli specifici contenuti della richiesta, la sussistenza dei relativi presupposti, ivi comprese le esigenze cautelari". Cass. Pen., sez. II, sent. 6525 del 21 novembre 2006, citada em BERRI, G. Formulario delle misure cautelari personali e reali. p. 158.
}

${ }^{551}$ Neste mesmo sentido, Giulio Berri: "Una eventuale misura cautelare, emessa in via officiosa serebbe affetta da nullità assoluta. Op. Cit. p. 154-155.

${ }_{552}$ Art. 390. Richiesta di convalida dell'arresto o del fermo 1. Entro quarantotto ore dall'arresto o dal fermo il pubblico ministero, qualora non debba ordinare la immediata liberazione dell'arrestato o del fermato, richiede la convalida al giudice per Le indagini preliminari competente in relazione al luogo dove l'arresto o il fermo e' stato eseguito.

2. Il giudice fissa l'udienza di convalida al piu' presto e comunque entro le quarantotto ore successive dandone avviso, senza ritardo, al pubblico ministero e al difensore. 3. L'arresto o il fermo diviene inefficace se il pubblico ministero non osserva le prescrizioni del comma 1. 
Ministério Público pode não comparecer, mas se não o fizer, deve enviar suas razões por escrito, pois sua participação é obrigatória ${ }^{553}$.

Interessante notar que a observância do contraditório para a adoção de medida cautelar é levada tão a sério na Itália que o Tribunal de Cassação entendeu ilegal a decisão do juiz que determinou a soltura do preso antes da audiência de convalidação ${ }^{554}$.

Vê-se que, muito embora tenha o processo penal brasileiro sofrido avassaladora influência do italiano, parece que, no tema do procedimento de tomada de decisão sobre uma medida cautelar, nossa legislação ainda se encontra presa às diretrizes do Código fascista de 1930.

553 Art. 391. Udienza di convalida 1. L'udienza di convalida si svolge in camera di consiglio con la partecipazione necessaria del difensore dell'arrestato o del fermato. 2. Se il difensore di fiducia o di ufficio non e' stato reperito o non e' comparso, il giudice provvede a norma dell'articolo 97 comma 4.((Il giudice altresi', anche d'ufficio, verifica che all'arrestato o al fermato sia stata data la comunicazione di cui ll'articolo 386, comma 1, o che comunque sia stato informato ai sensi del comma 1-bis dello stesso articolo, e provvede, se del caso, a dare o a completare la comunicazione o l'informazione ivi indicate.)) 3. Il pubblico ministero, se comparso, indica i motivi dell'arresto o del fermo e illustra le richieste in ordine alla liberta' personale. Il giudice procede quindi all'interrogatorio dell'arrestato o del fermato, salvo che questi non abbia potuto o si sia rifiutato di comparire; sente in ogni caso il suo difensore. 4. Quando risulta che l'arresto o il fermo e' stato legittimamente eseguito e sono stati osservati i termini previsti dagli articoli 386 comma 3 e 390 comma 1, il giudice provvede alla convalida com ordinanza. Contro l'ordinanza che decide sulla convalida, il pubblico ministero e l'arrestato o il fermato possono proporre ricorso per cassazione. 5. Se ricorrono le condizioni di applicabilita' previste dall'articolo 273 e taluna delle esigenze cautelari previste dall'articolo 274, il giudice dispone l'applicazione di una misura coercitiva a norma dell'articolo 291. Quando l'arresto e' stato eseguito per uno dei delitti indicati nell'articolo 381, comma 2, ovvero per uno dei delitti per i quali e' consentito anche fuori daí casi di flagranza, l'applicazione della misura e' disposta anche al di fuori dei limiti di pena previsti dagli articoli 274, comma 1, lettera c), e 280. 6. Quando non provvede a norma del comma 5, il giudice dispone com ordinanza la immediata liberazione dell'arrestato o del fermato. 7. Le ordinanze previste dai commi precedenti, se non sono pronunciate in udienza, sono comunicate o notificate a coloro che hanno diritto di proporre impugnazione. Le ordinanze pronunciate in udienza sono comunicate al pubblico ministero e notificate all'arrestato o al fermato, se non comparsi. I termini per l'impugnazione decorrono dalla lettura del provvedimento in udienza ovvero dalla sua comunicazione o notificazione. L'arresto o il fermo cessa di avere efficacia se l'ordinanza di convalida non e' pronunciata o depositata nelle quarantotto ore successive al momento in cui l'arrestato o il fermato e' stato posto a disposizione del giudice.

${ }^{554}$ È illegitimo il provvedimento com Il quale Il giudice per le indagini preliminari, investito delle contestuali richieste di convalida dell'arresto (o del fermo) e di applicazione di una misura cautelare, respinga quest'ultima e disponga La scarcerazione dell'arrestato (o del fermato) prima dell'udienza di convalida, attesto che l'art. 391, comma 3, c.p.p., prescrive espressamente che la decisione sull'applicazione della misura cautelare sia adottata nel contradditorio e quindi all'esito dell'udienza camarale; detta violazzione di legge, concernendo una disposizione che garantisce la partecipazione del pubblico ministero agli atti del procedimento, integra la nullità generale a regime intermedio di cui all'art. 178, lett. b), c.p.p., ma non determina, altresì, l'abnormità del provvedimento e la sua immediata ricorribilità per cassazione, poichè rientra mei poteri del giudice decidere sulla richiesta di applicazione di uma misura cautelari né si verifica, in conseguenza Del suo rigetto, uma situazione di irrimediable stallo del procedimento essendo consentito al pubblico ministero denunciare l'invalidità mediante l'appello de libertate di cui all'art. 310 c.p.p. (Cass. pen., sez. un., sent. 33 (cc. 22 novembre 2000) dep. il 13 dicembre 2000). 


\subsection{Espanha}

A inquisição nas ultracatólicas terras espanholas vicejou como em nenhuma outra parte do mundo ${ }^{555}$. Seguindo a regra dos países europeus continentais, a Espanha primeiro absorveu o direito romano imperial canônico consolidado nas Siete Partitas (século XIII) $)^{556}$ e, no século XIX, recebeu a influência da codificação napoleônica, culminando no Real Decreto, de 14 de setembro de 1882, que aprovou a Ley de Enjuiciamiento Criminal. Apesar de profundamente reformada - principalmente no que toca às medidas cautelares -, segue em vigor mais de 130 anos depois.

A transição do processo penal espanhol para um acusatório mais autêntico somente pode se dar após o término da ditadura franquista e a edição da Constituição de $1978^{557}$, que consagrou os direitos fundamentais processuais ${ }^{558}$ (processo com todas as garantias, princípio acusatório, legalidade e non bis in idem e as características essencialmente cautelares da prisão antes da sentença final transitada em julgado).

A jurisprudência do Tribunal Constitucional entende que embora o princípio acusatório não esteja explícito na Constituição, ele está implícito no "direito a um processo com todas as garantias" do art. $24.1^{559}$. Gimeno Sendra coloca que a aplicação de pena por parte do juiz deve ser precedida de acusação de órgão separado do julgador, conforme jurisprudência "abundante e categórica" do Tribunal Constitucional.

A abordagem do princípio acusatório na Espanha é focada principalmente pela doutrina e jurisprudência no aspecto da correlação entre pedido e decisão ${ }^{560}$. Nas decisões do Tribunal Constitucional consultadas, o foco das discussões acerca do sistema acusatório na Espanha é a correlação entre a acusação e a sentença, que já foi tratada neste trabalho como um dos argumentos pelos quais é inválida a decretação da prisão preventiva de ofício por parte do juiz.

\footnotetext{
${ }^{555}$ DESCHNER, KH. God and fascists. p. 52; LEA, H.C. A history of the inquisition of Spain. ${ }^{556}$ MAIER, J.B. op. cit. p. 300.

557 A transição da ditadura de Franco para a democracia começou com a morte do caudillo em 20 de novembro de 1975, se aperfeiçoou com a Constituição de 78 e se consolidou com a primeira vitória eleitoral do PSOE em 82.

${ }^{558}$ GIMENO S., J.V. Manual de derecho procesal penal.

${ }^{559}$ GIMENO S., J.V. EI Derecho Fundamental a un Proceso Acusatorio. p. 266-269, 271.

${ }^{560}$ Ex. sentença 155/2009, de 25 de junho (http://hj.tribunalconstitucional.es/HJ/es/Resolucion/Show/6574).
} 
Após a Constituição da redemocratização, várias modificações legais foram levadas a cabo para reformar a prisão preventiva, lá chamada de prisión provisional. Mencionamos a Ley 16/1980, de 22 de abril, a Ley Orgánica 7/1983, de 23 de abril, a Ley Orgánica 10/1984, de 26 de dezembro, e a Ley Orgánica 5/1995, de 22 de mayo, culminado na L.O. 513/2003, de 24 de outubro.

O novo procedimento de decisão sobre a prisão provisional foi fixado na LO 5/95, de 22 de maio, que disciplina principalmente o tribunal do júri na Espanha, mas tem reflexo no fortalecimento do acusatório em todo o sistema de justiça. Instituiu a audiência prévia para a decisão de medidas cautelares (não só para o Tribunal do Júri, mas para todo o processo penal, segundo sua exposição de motivos, teve como objetivo limitar a iniciativa do juiz penal em respeito à exigência do contraditório ${ }^{561}$ ).

O princípio acusatório e o princípio do contraditório (interligados) perfazem a linha mestra do sistema de prisão cautelar na Espanha desde 1995. A LO 5, inclusive, apesar de implementar o sistema acusatório mais precisamente ao Tribunal de Júri, enuncia um compromisso legal de se fortalecer o cumprimento dos princípios acusatório e contraditório, previstos na Constituição ${ }^{562}$. Em realidade, as modificações relativas às medidas cautelares significaram uma transição "de extraordinária transcendência" do processo penal espanhol em direção à aplicação do princípio acusatório $^{563}$.

Um dos importantes documentos para se entender tal reforma é a Circular n²/1995 do Ministério Público Fiscal ${ }^{564}$, com objetivo de abordar os problemas

\footnotetext{
${ }^{561}$ La introducción de un nuevo artículo 504 bis 2 en la Ley de Enjuiciamiento Criminal, respecto a la adopción de medidas cautelares de privación o restricción de la libertad, incorpora una necesaria audiencia del Ministerio Fiscal, las partes y el imputado asistido de letrado, inspirada en el principio acusatorio, y suprime la exigencia de ratificación del auto de prisión. De esta forma, la limitación de la iniciativa judicial se equilibra con la instauración de los beneficios del contradictorio, sin perjuicio del carácter reformable de las medidas adoptadas durante todo el curso de la causa.

562 "Disposição Final Quarta : Cuarta Futuras reformas procesales. En el plazo de un año, desde la aprobación de la presente Ley, el Gobierno enviará a las Cortes Generales un proyecto de Ley de modificación de la Ley de Enjuiciamiento Criminal, generalizando los criterios procesales instaurados en esta Ley y en el que se establezca un procedimiento fundado en los principios acusatorio y de contradicción entre las partes, previstos en la Constitución, simplificando asimismo el proceso de investigación para evitar su prolongación excesiva. Asimismo, en dicho plazo, se adoptarán las reformas legales necesarias que adapten a tal procedimiento el Estatuto y funciones del Ministerio Fiscal, y se habilitarán por las Cortes Generales y el Gobierno los medios materiales, técnicos y humanos necesarios."

${ }^{563}$ MACIÁ G., R.; ROIG A., M. Op.cit. p. 77.

${ }^{564}$ www.fiscal.es acessado em 20/04/2014.
} 
interpretativos da reforma advinda da LO 5/1995 e harmonizar a atuação do Ministério Público na Espanha. Coloca-se, então (tudo de acordo com a Circular n²), que a reforma nas medidas cautelares na Espanha podem ser sintetizadas em dois pontos chave: as decisões sobre prisão exigem: "1. Una solicitud de parte - principio acusatorio- (inciso final del párrafo tercero del art. 504 bis, 2, Y párraro 3.0 del mI. 539); 2. Una previa audie ncia con asistencia de las partes - principio de contradicción- (arts. 504 bis, 2, párraro 12 y 539.3. $\left.{ }^{\circ}\right) ”$.

A LO 5 foi a primeira a instituir a audiência prévia em, no máximo, 72 horas a contar do momento em que o réu é posto à disposição da Justiça, com a presença das partes, para a fixação de medidas cautelares. A presença do Ministério Público é obrigatória e as partes podem produzir provas referentes à necessidade ou desnecessidade das medidas cautelares. Maciá sustenta ${ }^{565}$ que provas e referência ao caso concreto é apenas circunstancial, pois as decisões sobre as medidas cautelares devem ser tratadas como autônomas.

Houve quem entendeu que a mais importante novidade da LO 5 foi justamente a necessidade de que uma das partes requeira a medida cautelar para que esta seja julgada e implementada, ou seja, a proibição da decretação de ofício ${ }^{566}$.

A LO 513/2003 veio reforçar as disposições da LO $5^{567}$. De acordo com sua exposição de motivos, a LO 513 teve como objetivo adequar a prisão provisional (prisão preventiva) à jurisprudência do Tribunal Constitucional (principalmente à sentença 47/2000, que compilou a jurisprudência do Tribunal acerca dos requisitos da prisão

\footnotetext{
${ }^{565}$ MACIÁ G., R.; ROIG A., M. Op.cit. p. 78.

${ }^{566}$ Neste sentido MACIÁ G., R.; ROIG A., M. El nuevo sistema de adopción de la medida cautelar de la prisión provisional. "Por outra parte, la innovación más importante introducida por la LO 5/1995 es, sin duda, la necesidad de que alguna de las partes interese la adopción de la medida cautelar de prisión provisional para que el juez, oídas las alegaciones de las que concurrieran, pueda decretar esta medida, en caso contrario el Juez necesariamente acordará la cesación de la detención e inmediata puesta en libertad del imputado. Con ello, el legislador no sólo introduce el principio acusatório en esta fase, sino que también refuerza el necesario carácter excepcional que debe revestir esta medida. Tan sólo puede el Juez acordar “de oficio" la prisión provisional si por cualquier razón la comparecencia no pudiera celebrarse, y siendo requisitos imprescindibles: en primer lugar, que concurran los presupuestos y estime riesgo de fuga, y en segundo lugar, que convoque nuevamente la comparecencia dentro de las setenta y dos horas siguientes."

${ }^{567}$ Trecho das exposições de motivos da L.O. 513: "En lo que respecta al procedimiento, se mantiene la regla, introducida en la reforma operada por la Ley Orgánica 5/1995, de 22 de mayo, de que la prisión provisional sólo podrá ser acordada a instancia del Ministerio Fiscal o de una parte acusadora. Asimismo, se mantiene la regla de que la medida sólo puede acordarse tras la celebración de una audiencia en la que el juez o tribunal haya oído las alegaciones de las partes y haya tenido en cuenta, en su caso, las pruebas aportadas."
} 
preventiva) quanto à adequação desta medida cautelar aos direitos constitucionais de liberdade e de presunção de inocência ${ }^{568}$.

Consolidou-se, então, a redação do art. 505 da Ley de Enjuiciamiento ${ }^{569}$, que estabeleceu as regras para a realização da audiência prévia, de modo que se a parte acusadora não requerer a prisão, o juiz deve, necessariamente, por em liberdade o acusado $^{570}$. Em uma disposição que reforça uma das características mais marcantes do sistema acusatório, a oralidade (ver capítulo XX), a lei espanhola exige a audiência e a participação da acusação mesmo nos casos em que a questão da aplicação de uma medida cautelar sobressai durante a instrução criminal (art. 539 571 ). Mesmo nos casos

${ }^{568}$ http://noticias.juridicas.com/base_datos/Penal/lo13-2003.html\#I26. Acessado em 10/04/2014. 569 Artículo 505

1. Cuando el detenido fuere puesto a disposición del juez de instrucción o tribunal que deba conocer de la causa, éste, salvo que decretare su libertad provisional sin fianza, convocará a una audiencia en la que el Ministerio Fiscal o las partes acusadoras podrán interesar que se decrete la prisión provisional del imputado o su libertad provisional con fianza.

En los supuestos del procedimiento regulado en el título III del libro IV de esta ley, este trámite se sustanciará con arreglo a lo establecido en el artículo 798, salvo que la audiencia se hubiera celebrado con anterioridad.

2. La audiencia prevista en el apartado anterior deberá celebrarse en el plazo más breve posible dentro de las 72 horas siguientes a la puesta del detenido a disposición judicial y a ella se citará al imputado, que deberá estar asistido de letrado por él elegido o designado de oficio, al Ministerio Fiscal y a las demás partes personadas. La audiencia habrá de celebrarse también para solicitar y decretar, en su caso, la prisión provisional del imputado no detenido o su libertad provisional con fianza.

3. En dicha audiencia, si el Ministerio Fiscal o alguna parte acusadora solicitare que se decrete la prisión provisional del imputado o su libertad provisional con fianza, podrán quienes concurrieren realizar alegaciones y proponer los medios de prueba que puedan practicarse en el acto o dentro de las 72 horas antes indicadas en el apartado anterior.

4. El juez o tribunal decidirá sobre la procedencia o no de la prisión o de la imposición de la fianza. Si ninguna de las partes las instare, acordará necesariamente la inmediata puesta en libertad del imputado que estuviere detenido.

5. Si por cualquier razón la audiencia no pudiere celebrarse, el juez o tribunal podrá acordar la prisión provisional, si concurrieren los presupuestos del artículo 503, o la libertad provisional con fianza. No obstante, dentro de las siguientes 72 horas, el juez o tribunal convocará una nueva audiencia, adoptando las medidas a que hubiere lugar por la falta de celebración de la primera audiencia.

6. Cuando el detenido fuere puesto a disposición de juez distinto del juez o tribunal que conociere o hubiere de conocer de la causa, y el detenido no pudiere ser puesto a disposición de este último en el plazo de 72 horas, procederá el primero de acuerdo con lo previsto en los apartados anteriores. No obstante, una vez que el juez o tribunal de la causa reciba las diligencias, oirá al imputado, asistido de su abogado, tan pronto como le fuera posible y dictará la resolución que proceda.

$570 \quad$ "El legislador sí ha excluído, expresa e inequívocamente, la posibilidad de que un tribunal adopte la prisión provisional de un detenido y/o imputado si no existe petición de parte. El legislador sí ha excluído, expresa e inequívocamente, la posibilidad de que un tribunal adopte la prisión provisional en el caso de que las partes nunca hayan apreciado motivos para ello". ORGA L., J.C. Prisión provisional y principio acusatório.

${ }^{571}$ Artículo 539 la causa.

Los autos de prisión y libertad provisionales y de fianza serán reformables durante todo el curso de

En su consecuencia, el imputado podrá ser preso y puesto en libertad cuantas veces sea procedente, y la fianza podrá ser modificada en lo que resulte necesario para asegurar las consecuencias del juicio. 
excepcionais, em que é cometido ao juiz determinar uma medida cautelar mais gravosa durante o curso da ação penal, é obrigatória a realização da audiência em 72 horas (deixando esta prisão preventiva parecida com uma prisão em flagrante). Ainda que durante o processo, se houver as condições para a prisão, mesmo assim o pedido do Ministério Público é indispensável.

Na Espanha não mais é possível a decretação da prisão provisional sem a realização de uma audiência e sem o requerimento do Ministério Público. O juiz que encarcera alguém ex officio pode, inclusive, incorrer no crime de detención ilegal (arts. 163 e seguintes do Código Penal Espanhol) ${ }^{572}$.

\subsection{Portugal}

Portugal, jurisdição da qual nasceu a brasileira, teve um desenvolvimento semelhante à Espanha. Partiu de uma justiça penal extremamente inquisitória, plasmada nas ordenações, passando a receber influência da codificação napoleônica após o século XIX. Em 1929, durante a chamada Ditadura Nacional portuguesa, foi editado o Código de Processo Penal (Lei n. ${ }^{\circ}$ 16489, de 15 de Fevereiro de 1929) que serviu ao Professor António de Oliveira Salazar durante seu longo período de regime autoritário, chamado Estado Novo, como no Brasil.

Após a redemocratização, foi editada a Constituição de 1976, que, dentre outras disposições, estabeleceu expressamente, como já foi dito, o sistema acusatório. O

Para acordar la prisión o la libertad provisional con fianza de quien estuviere en libertad o agravar las condiciones de la libertad provisional ya acordada sustituyéndola por la de prisión o libertad provisional con fianza, se requerirá solicitud del Ministerio Fiscal o de alguna parte acusadora, resolviéndose previa celebración de la comparecencia a que se refiere el artículo 505.

Párrafo 3. ${ }^{\circ}$ del artículo 539 redactado por el apartado tres del artículo segundo de la L.O. 13/2003, de 24 de octubre, de reforma de la Ley de Enjuiciamiento Criminal en materia de prisión provisional («B.O.E.» 27 octubre).Vigencia: 28 octubre 2003

No obstante, si a juicio del juez o tribunal concurrieren los presupuestos del artículo 503, procederá a dictar auto de reforma de la medida cautelar, o incluso de prisión, si el imputado se encontrase en libertad, pero debiendo convocar, para dentro de las 72 horas siguientes, a la indicada comparecencia.

Párrafo $4^{\circ}$ del artículo 539 redactado por el apartado tres del artículo segundo de L.O. 13/2003, de 24 de octubre, de reforma de la Ley de Enjuiciamiento Criminal en materia de prisión provisional («B.O.E.» 27 octubre).Vigencia: 28 octubre 2003

Siempre que el Juez o Tribunal entienda que procede la libertad o la modificación de la libertad provisional en términos más favorables al sometido a la medida, podrá acordarla, en cualquier momento, de oficio y sin someterse a la petición de parte.

572 ORGA L., J.C. Op. cit. 
atual Código de Processo em vigor em Portugal é de 1987 (DL n. ${ }^{\circ}$ 78/87, de 17 de fevereiro).

Desde a sua gênese, o novo Código previa a possibilidade de decretação de ofício das medidas cautelares (ou medidas de coação, como são chamadas em Portugal), no entanto, a redação original do art. $187^{573}$ (com disposição semelhante à redação do art. 311 do Código de Processo Penal brasileiro, disposta pela Lei 12.403/2011), já proibia o decreto de prisão cautelar de ofício durante a fase de investigações, além de preferir a

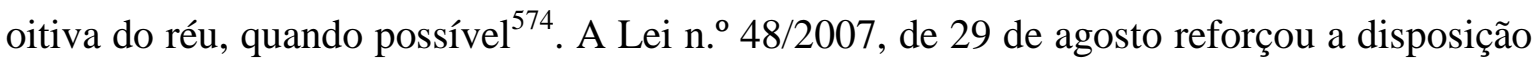

5731 - As medidas de coacção e de garantia patrimonial são aplicadas por despacho do juiz, durante o inquérito a requerimento do Ministério Público e depois do inquérito mesmo oficiosamente, ouvido o Ministério Público.

2 - A aplicação referida no número anterior é precedida, sempre que possível e conveniente, de audição do arguido e pode ter lugar no acto do primeiro interrogatório judicial.

${ }^{574}$ Sobre o tema, interessante julgado do Tribunal da Relação de Lisboa de 2011. As circunstâncias fáticas encerram a questão quanto à possibilidade de o juiz, durante o inquérito, decretar a prisão preventiva quando o Ministério Público tenha requerido medida de coação menos gravosa. Após a decisão judicial de primeira instância, o próprio Ministério Público recorreu ao Tribunal sustentando que "sendo o Ministério Publico nos termos consagrados no nosso Direito Processual Penal o verdadeiro detentor da acção Penal, é a este que cabe decidir se a obrigação de permanência na habitação é ou não suficiente para acautelar os interesses em causa, (...) não podendo o Mmo Juiz aplicar, ou manter, uma medida de coacção mais gravosa para o Arguido do que aquela que é requerida pelo Ministério Publico (número 2 do art. $194 .{ }^{\circ}$ CPP)." Colhe-se de recho da decisão do Tribunal da Relação: "Com a filosofia do sistema processual penal de estrutura acentuadamente acusatória e com o papel do juiz de instrução na fase de inquérito claramente vocacionado para a tutela dos direitos, liberdades e garantias " $O$ limite estabelecido à amplitude do poder de decisão do juiz de instrução em nada fere a independência judicial e é antes sistemática e teleologicamente fundado, radicando na estrutura acusatória do processo penal e no significado autêntico do papel de juiz das liberdades que o juiz de instrução criminal deve exercer na fase do inquérito e em especial no contexto das medidas de coacção" - Nuno Brandão, Medidas de Coacção: O Procedimento de Aplicação na Revisão do Código de Processo Penal, texto da comunicação apresentada nas Jornadas sobre a Revisão do Código de Processo Penal promovidas pelo CEJ.), não se compreenderia uma opção legislativa em que num momento inicial se impedisse o juiz de fixar medidas de coacção mais graves que as propostas pelo Ministério Público para se permitir que ulteriormente as pudesse manter contra a vontade do dominus do inquérito.

Afinal, esta norma estabelece uma limitação legal aos poderes do juiz, à semelhança do que ocorre com a limitação imposta nos termos do art. $16^{\circ} n^{o} 3$ do Código de Processo Penal, sem ofender o princípio da reserva da função jurisdicional: na verdade, quem decide sobre a medida de coacção é sempre o juiz e em função de tal juízo deve determinar a medida de coacção concretamente aplicável, nesta operação movendo-se sempre dentro dos limites da lei. Para esse efeito, «lei» não é apenas o conjunto de normas que determinam as condições gerais de aplicação das medidas de coacção mas também a norma do art. $194^{\circ} n^{\circ}$ 2 do Código de Processo Penal que estabelece o limite máximo da medida de coacção aplicável, em termos de precisão e nitidez suficientes para cumprir, a mais que uma função de garantia do arguido, as exigências feitas ao legislador pela separação que deve existir entre os poderes (a competência) do Ministério Público e do julgador, e bem assim, para poder servir de fundamento normativo da decisão a proferir pelo juiz e para possibilitar o controlo dessa mesma decisão impedindo o arbítrio ( Parafraseámos o acórdão do Tribunal Constitucional de 22.1.1991, no proc. 211/89, na AJ, $n^{\circ} 15 / 16$, 77/78, citado por Simas Santos e LealHenriques no seu Código de Processo Penal Anotado, vol. $1^{o}, 3^{a}$ ed., pg.s 168 e 169, proferido a propósito da constitucionalidade do art. $16^{\circ} n^{o} 3$ do Código de Processo Penal).". Tribunal da Relação de Lisboa. Processo $n^{\circ}$ 189/10.0PPLSB-A.L1-3. Rel. Jorge Raposo, julgado em 23/3/2011. Disponível em http://www.dgsi.pt/jtrl.nsf/33182fc732316039802565fa00497eec/a153f7d370c4832a8025786100613df7?Op enDocument\&Highlight=0,obriga\%C3\%A7\%C3\%A3o,perman\%C3\%AAncia,habita\%C3\%A7\%C3\%A3ohtt p://www.dgsi.pt/jtrl.nsf/33182fc732316039802565fa00497eec/a153f7d370c4832a8025786100613df7?Open 
quanto às medidas de garantia patrimonial, dispondo no art. 194 que "2. Durante o inquérito, o juiz não pode aplicar medida de coacção ou de garantia patrimonial mais grave que a requerida pelo Ministério Público, sob pena de nulidade”.

O art. 194 foi reformado pela Lei n. ${ }^{\circ} 20 / 2013$, de 21 de fevereiro ${ }^{575}$, mas a disposição de possibilidade de decretação da prisão preventiva de ofício pelo juiz durante o inquérito segue vigente até o momento. Entretanto, a reforma de 2013 reforçou a necessidade da audição do arguido sempre que possível, justificada a impossibilidade (parágrafo $4^{\circ}$ ).

Document\&Highlight=0,obriga\%C3\%A7\%C3\%A3o,perman\%C3\%AAncia,habita\%C3\%A7\%C3\%A3o. Acessado em 15/4/2014.

${ }^{575}$ Artigo 194. ${ }^{\circ}$

Audição do arguido e despacho de aplicação

1 - À exceção do termo de identidade e residência, as medidas de coação e de garantia patrimonial são aplicadas por despacho do juiz, durante o inquérito a requerimento do Ministério Público e depois do inquérito mesmo oficiosamente, ouvido o Ministério Público, sob pena de nulidade.

2 - Durante o inquérito, o juiz pode aplicar medida de coação diversa, ainda que mais grave, quanto à sua natureza, medida ou modalidade de execução, da requerida pelo Ministério Público, com fundamento nas alíneas a) e c) do artigo 204..$^{\circ}$

3 - Durante o inquérito, o juiz não pode aplicar medida de coação mais grave, quanto à sua natureza, medida ou modalidade de execução, com fundamento na alínea b) do artigo $204 .{ }^{\circ}$ nem medida de garantia patrimonial mais grave do que a requerida pelo Ministério Público, sob pena de nulidade.

4 - A aplicação referida no n. ${ }^{\circ} 1$ é precedida de audição do arguido, ressalvados os casos de impossibilidade devidamente fundamentada, e pode ter lugar no acto de primeiro interrogatório judicial, aplicando-se sempre à audição o disposto no n. ${ }^{\circ} 4$ do artigo $141^{\circ}$

5 - Durante o inquérito, e salvo impossibilidade devidamente fundamentada, o juiz decide a aplicação de medida de coacção ou de garantia patrimonial a arguido não detido, no prazo de cinco dias a contar do recebimento da promoção do Ministério Público.

6 - A fundamentação do despacho que aplicar qualquer medida de coacção ou de garantia patrimonial, à excepção do termo de identidade e residência, contém, sob pena de nulidade:

a) A descrição dos factos concretamente imputados ao arguido, incluindo, sempre que forem conhecidas, as circunstâncias de tempo, lugar e modo;

b) A enunciação dos elementos do processo que indiciam os factos imputados, sempre que a sua comunicação não puser gravemente em causa a investigação, impossibilitar a descoberta da verdade ou criar perigo para a vida, a integridade física ou psíquica ou a liberdade dos participantes processuais ou das vítimas do crime;

c) A qualificação jurídica dos factos imputados;

d) A referência aos factos concretos que preenchem os pressupostos de aplicação da medida, incluindo os previstos nos artigos $193 .^{\circ}$ e $204 .^{\circ}$

7 - Sem prejuízo do disposto na alínea b) do número anterior, não podem ser considerados para fundamentar a aplicação ao arguido de medida de coacção ou de garantia patrimonial, à excepção do termo de identidade e residência, quaisquer factos ou elementos do processo que lhe não tenham sido comunicados durante a audição a que se refere o n. ${ }^{\circ} 3$.

8 - Sem prejuízo do disposto na alínea b) do $n .^{\circ} 6$, o arguido e o seu defensor podem consultar os elementos do processo determinantes da aplicação da medida de coação ou de garantia patrimonial, à exceção do termo de identidade e residência, durante o interrogatório judicial e no prazo previsto para a interposição de recurso.

9 - O despacho referido no n. ${ }^{\circ} 1$, com a advertência das consequências do incumprimento das obrigações impostas, é notificado ao arguido.

10 - No caso de prisão preventiva, o despacho é comunicado de imediato ao defensor e, sempre que $o$ arguido o pretenda, a parente ou a pessoa da sua confiança. 
Em conclusão, temos que hoje Portugal tem um regime de implementação da prisão preventiva semelhante ao Brasil, com exceção de disposição sobre a preferência de oitiva do acusado. Admite-se a prisão preventiva de ofício, mas somente após iniciado o processo penal.

\subsection{Chile}

Caso interessante de estudo, antes da primeira década do século XXI, o Chile mantinha um sistema inquisitório autêntico, tendo, inclusive, abandonado a instituição do Ministério Público desde 1929, exercendo os juízes as funções de acusar e $\operatorname{julgar}^{576}$.

Depois da redemocratização (notadamente desde 1995), inicia-se um processo de reformas que visaram aniquilar por completo todos os resquícios inquisitórios do sistema de justiça. Passou-se de uma recrudecida inquisição para um processo adversarial assemelhado ao anglo-saxão.

O marco do processo foi a edição do Código de Processo Penal de setembro de 2000 (Lei n ${ }^{\circ}$ 19.696), inspirado no Código de Processo Penal tipo para a Iberoamérica, no Código de Processo Penal cordobês e nos sistemas já há muito vigentes no Reino Unido, Estados Unidos da América, Canadá, Nova Zelândia e Austrália. Contudo, a reforma importou em muitas outras inovações legislativas, como a própria reforma da Constituição em 1997, reforma da lei orgânica dos tribunais, criação da Defensoria Pública e do Ministério Público.

O procedimento foi reformulado, abandonando-se a escrituração ${ }^{577}$ e a burocracia herdadas do tempo colonial e implementando-se o juízo oral como centro de todo o processo penal. Não há outro método de tomada de decisão no processo penal do Chile que não seja a audiência, com a presença das partes à frente de um juiz que não recebe informação alguma da causa previamente. Não foge a esta regra a imposição de medidas cautelares. Uma destas audiências do sistema seria o controle da detenção, presidida pelo juiz de garantia, utilizada para se decidir os pedidos da acusação a respeito

\footnotetext{
${ }^{576}$ STRUENSEE, E.; MAIER, J.B. J. Introdución in Las reformas. p. 22.
}

${ }^{577}$ Apenas as sentenças são escritas no novo sistema. 
de medidas cautelares. Não se concebe que o juiz possa decretar a segregação cautelar fora do método oral e tampouco decidir oficiosamente.

A própria base ideológica das medidas cautelares foi modificada. De acordo com Duce e Riego ${ }^{578}$, professores que representaram o núcleo duro dos processualistas que divisaram a reforma, o sistema inquisitivo - reforçado pela ideia de expediente escrito - antes em vigor no Chile, trazia como característica que o próprio processo consistisse em um castigo, uma pena, e, por isso, o que acontecia durante seu trâmite era de central importância. O próprio processo era visto como uma forma de controle social. Neste contexto estavam inseridos os crimes para os quais havia obrigatoriamente a prisão preventiva, sendo indiferentes as circunstâncias de cada processo em si. Assim, passar para o sistema acusatório significou colocar a medida cautelar como simples garantia do fim do próprio processo, e não com relação ao castigo final do réu. Instaurou-se o princípio da excepcionalidade de qualquer medida cautelar.

Com a reforma, o sistema de justiça chileno passou a dar respostas jurisdicionais de forma muito mais célere. Estudo realizado por pesquisadores da Universidade Diego Portales concluiu que a reforma importou em uma diminuição de mais de $40 \%$ nos prazos totais do processo. Hoje, com o sistema de audiências para a tomada de decisões, a média de duração de um processo já computados os tempos dos recursos, é de, por exemplo, 5,7 meses na região IV (Coquimbo) e 5,3 meses na região IX (Araucanía) ${ }^{579}$. Assim, a prisão cautelar deixa de representar o sustentáculo do processo, quando este dura anos. É no contexto de um processo penal com duração de meses que devem ser entendidas as medidas cautelares no Chile.

De acordo com Núñez Vásquez ${ }^{580}$, os requisitos de natureza processual da imposição de uma prisão preventiva são: a) a jurisdição e a competência para decretá-la; b) a legitimação ativa para impetrá-la; c) a legitimação passiva para ser sujeito da prisão preventiva; e d) a oportunidade para expedi-la. Os chilenos entendem que o próprio juiz não é o legitimado ativo para requerer a prisão, razão pela qual não pode decretá-la de

\footnotetext{
${ }^{578}$ DUCE, RIEGO. Proceso Penal. Pag. 246 e seguintes.

579 DUCE, BAYTELMAN. Evaluación de la reforma procesal penal: estado de uma reforma em marcha. p. 264.

${ }^{580}$ NÚÑEZ V., J.C. Tratado del proceso penal y del juicio oral. p. 303.
} 


\author{
ofício $^{581}$. Ademais, é o Ministério Público (e nunca a polícia) quem deve levar a juízo as \\ circunstâncias de fato e de direito que sustentam o requerimento de prisão preventiva, a \\ teor do art. 140 do Código ${ }^{582}$.
}

Não há espaço para a decretação da prisão preventiva de ofício no Chile após a reforma acusatória.

581 "La legitimación para impetrar la medida solamente la poseen el ministerio público o el querellante, y por
ende, no pueden solicitarla ni la víctima que no se ha querellado, ni las partes civiles del proceso penal, como
tampoco puede decretarla de oficio el juez." Idem. Ibidem.
582 Artículo 140.- Requisitos para ordenar la prisión preventiva. Una vez formalizada la investigación, el
tribunal, a petición del Ministerio Público o del querellante, podrá decretar la prisión preventiva del imputado
siempre que el solicitante acreditare que se cumplen los siguientes requisitos:

a) Que existen antecedentes que justificaren la existencia del delito que se investigare;

b) Que existen antecedentes que permitieren presumir fundadamente que el imputado ha tenido participación en el delito como autor, cómplice o encubridor, y

c) Que existen antecedentes calificados que permitieren al tribunal considerar que la prisión preventiva es indispensable para el éxito de diligencias precisas y determinadas de la investigación, o que la libertad del imputado es peligrosa para la seguridad de la sociedad o del ofendido, o que existe peligro de que el imputado se dé a la fuga, conforme a las disposiciones de los incisos siguientes.

Se entenderá especialmente que la prisión preventiva es indispensable para el éxito de la investigación cuando existiere sospecha grave y fundada de que el imputado pudiere obstaculizar la investigación mediante la destrucción, modificación, ocultación o falsificación de elementos de prueba; o cuando pudiere inducir a coimputados, testigos, peritos o terceros para que informen falsamente o se comporten de manera desleal o reticente.

Para estimar si la libertad del imputado resulta o no peligrosa para la seguridad de la sociedad, el tribunal deberá considerar especialmente alguna de las siguientes circunstancias: la gravedad de la pena asignada al delito; el número de delitos que se le imputare y el carácter de los mismos; la existencia de procesos pendientes, y el hecho de haber actuado en grupo o pandilla.

Se entenderá especialmente que la libertad del imputado constituye un peligro para la seguridad de la sociedad, cuando los delitos imputados tengan asignada pena de crimen en la ley que los consagra; cuando el

imputado hubiere sido condenado con anterioridad por delito al que la ley señale igual o mayor pena, sea que

la hubiere cumplido efectivamente o no; cuando se encontrare sujeto a alguna medida cautelar personal, en

libertad condicional o gozando de alguno de los beneficios alternativos a la ejecución de las penas privativas o restrictivas de libertad contemplados en la ley.

cuando

Se entenderá que la seguridad del ofendido se encuentra en peligro por la libertad del imputado

existieren antecedentes calificados que permitieren presumir que éste realizará atentados en contra de aquél, o en contra de su familia o de sus bienes. 


\section{CONCLUSÕES}

\subsection{Inconstitucionalidade das normas que dispõem sobre a}

possibilidade de decretação de prisão preventiva de ofício

Com o presente trabalho procurou-se demonstrar que, em uma perspectiva histórica do processo penal, o sistema inquisitivo, focado na figura do juizacusador e em um ideal de justiça focado na implementação de políticas públicas, foi dando lugar paulatinamente e com movimentos de avanço e retrocesso (reforma e contrarreforma) a um sistema acusatório, com separação clara entre acusador e julgador, e mais próprio aos Estados Democráticos de Direito fortalecidos na segunda metade do século XX.

O Brasil, democratizado após a entrada em vigor da Constituição de 1988, consagrou implicitamente o princípio acusatório nas normas da mais alta hierarquia do sistema normativo. A presunção da inocência, a ampla defesa, o contraditório e a titularidade da ação penal pública em mãos do Ministério Público fortaleceram a imparcialidade e a isenção do juiz penal, reduzindo sua função de agente de política de segurança pública e incrementando seu papel como o árbitro de uma disputa, que julga exposto ao contraditório, em regra. O princípio constitucional acusatório condiciona toda a justiça penal em um sistema acusatório, de modo que regras que encontram sua fundamentação em um princípio inquisitivo, já não mais vigente no Brasil, são inconstitucionais e, por isso, inválidas.

Mais recentemente, reformas no Código de Processo Penal diversificaram as medidas cautelares, reforçaram o aspecto cautelar da prisão preventiva introduziram elementos que prestigiam o sabor de contenda do processo (como a audiência una e o cross-examination) e restringiram a possibilidade de decretação da prisão preventiva de ofício durante o curso do processo penal.

Embora a Constituição de 1988 tenha representado uma viragem completa nos princípios do processo penal, e algumas reformas tenham fortalecido a coesão do sistema acusatório, o Código de 1941, criado sob a égide de um regime de inspiração fascista e comprometido com um ideal de Justiça Penal essencialmente inquisitória, seguiu em vigor. Mas não só seu texto sobreviveu por mais de sete décadas, 
como sua ideologia permaneceu guiando os rumos do processo penal. Entre as normas ainda vigentes encontramos aquelas que permitem ao juiz decretar a prisão preventiva sem o requerimento do Ministério Público (como, por exemplo, os artigos 310, inciso II, 311 e 387, $\S 1^{\circ}$, todos do Código de Processo Penal ${ }^{583}$, e o art. 20 da Lei 11.340/2006). O problema se agrava em um processo penal extremamente verticalizado, burocrático e moroso, em que a prisão preventiva pode perdurar por anos. A decisão sobre a prisão preventiva, por ser uma das mais importantes no curso do processo penal, pois vulnera o status libertatis do acusado, é de grande importância durante o curso do processo penal.

Do ponto de vista histórico, para saber se um sistema é inquisitório ou acusatório, é relevante saber a qual parte é dado o poder de persecução e se o juiz pode iniciar procedimentos motu proprio. No caso das decisões anteriores à propositura da denúncia (incluindo a "conversão do flagrante em preventiva"), nem mesmo há processo iniciado e o juízo já decreta a medida mais drástica a que se pode chegar através do processo. Mesmo quando já está instaurado o processo, pode-se entender que o procedimento de medida cautelar é um “subprocedimento", já que a cognição necessária para se decidir uma medida cautelar é diversa daquela necessária para uma condenação ou absolvição. Quando o juiz decide de ofício, ele não só inicia este "subprocedimento", como o termina com sua decisão.

Do poder do juiz de se colocar no lugar da parte e a importância da prisão preventiva concluímos que a quintessência do decreto de ofício é o princípio inquisitivo, que sufoca o contraditório, ameaça a imparcialidade subjetiva e objetiva do juízo e torna o juiz um agente de segurança pública. $\mathrm{O}$ acusado é privado de seu direito à liberdade sem um devido processo legal. O desenvolvimento do due process não se deu simplesmente para evitar uma condenação final arbitrária, mas sim uma privação de direito arbitrária.

A escolha por manter o instituto da decretação de ofício no ordenamento representa mais do que uma opção estritamente técnico-jurídica, constituindo uma adesão ideológica, histórica e filosófica de grandes proporções.

\footnotetext{
${ }^{583}$ Os três dispositivos do Código de Processo Penal citados tiveram sua redação modificada após a entrada em vigor da Constituição Federal de 1988, razão pela qual não tratamos tecnicamente de normas não recepcionadas, mas, sim de normas inconstitucionais.
} 
Por todos estes motivos, as normas de decretação de ofício da prisão preventiva representam uma "violação ao postulado da unidade do sistema", por isso são "valorativamente isoladas" 584 .

Impedir a atuação de ofício para determinar uma segregação cautelar seria instituir mais uma daquelas "regras de salvaguarda que a experiência demonstrou necessárias nos procedimentos judiciais", que Henry Charles Lea dizia que a igreja católica não adotava para separar o acusador do juiz ao tempo da Idade Média ${ }^{585}$.

\subsection{Solução possível de acordo com o sistema acusatório}

O desenvolvimento do sistema acusatório no direito comparado inspirou possibilidade de procedimento de tomada de decisão sobre a prisão preventiva de forma consentânea com os valores do devido processo legal. Trata-se das "audiências prévias ao juízo" (também chamadas de "audiências de garantia", "audiências de controle de detenção", e, no Brasil, de "audiência de custódia") que, além de assegurarem a imparcialidade do juízo, garantem a máxima possibilidade de defesa do réu ${ }^{586}$, que será sempre representado por advogado e poderá ouvir e ser ouvido, levando o contraditório a sua expressão máxima neste momento crítico do processo, que é a deliberação sobre uma medida cautelar.

Se o contraditório consiste na ciência dos atos processuais e na possibilidade de reagir, que melhor oportunidade de exercê-lo que em uma audiência pública, com a presença de ambas as partes e com o juiz objetivamente imparcial, que não tem contato prévio algum com as informações do caso, e decide exposto à discussão das partes.

A audiência de garantia seria providencial principalmente nos casos em que, tendo o réu sido preso em flagrante, surja para o Ministério Público a intenção de

\footnotetext{
${ }^{584}$ Expressões de CANARIS, C.W. Pensamento sistemático e conceito de sistema na Ciência do Direito. p. 235 e seguintes. Canaris inclusive coloca que esses "corpos estranhos" no sistema devem ter, se considerados válidos, interpretação restritiva e nunca extensiva.

585 Op. cit. p. 6559.

${ }^{586}$ MACIÁ G., R.; ROIG A., M. El nuevo sistema de adopción de la medida cautelar de la prisión provisional. p. 81 .
} 
requerer a conversão para a prisão preventiva, retirando-se a eficácia do inciso II do art. 310 do atualmente vigente Código de Processo Penal.

Além de impedir a ação de ofício do juiz e de promover a plena vigência do contraditório, permite que outros dois elementos essenciais do sistema acusatório sejam prestigiados: a publicidade (garantindo a transparência democrática das decisões) e a oralidade. A imparcialidade objetiva do juiz também seria mais garantida, com a menor importância do inquérito, pois o juiz teria acesso apenas às aportações orais das partes (advogado e Ministério Público) nesta fase tão delicada do processo, que é a decisão sobre as medidas cautelares. Por fim, resolver-se-ia o problema da incongruência lógica do método de se tomar decisões ${ }^{587}$, ao menos na primeira instância.

Sem uma audiência com as duas partes presentes, os estereótipos (falsas representações) de que fala Hassemer, não só do réu, mas também do promotor, tomam conta da compreensão cênica do juiz e distorcem o processo penal. Trata-se de abrir os horizontes da comunicação restritos no atual modelo de tomada de decisão sobre a cautelar penal e, nos dizeres de Hassemer, adaptar o processo judicial a formas discursivas de comunicação, fortalecendo a capacidade comunicativa dos participantes do processo $^{588}$.

É preciso dizer que, no tema do método da tomada de decisão sobre a medida cautelar, o projeto de novo Código de Processo Penal já nasce ultrapassado, pois, embora intencione instituir no Brasil a figura do juiz de garantia - promovendo " $o$ distanciamento do juiz do processo, responsável pela decisão de mérito" "589 -, mantém a forma burocrática, escritural e inquisitória da tomada de decisão sobre a prisão preventiva.

Necessário dizer que está em trâmite no Senado Federal o Projeto de Lei 554/2011, de autoria do Senador Antonio Carlos Valadares, que, reformando o art. 306 do Código de Processo Penal ${ }^{590}$, institui a audiência de custódia no Brasil. O texto já foi

\footnotetext{
${ }^{587}$ Ver nota 109.

${ }^{588}$ Op.cit. p. 183 e seguintes.

${ }^{589}$ Expressões de sua exposição de motivos.

590 Texto atual, já com as emendas determinadas pelo substitutivo apresentada pela Comissão de Direitos Humanos e Legislação Participativa do Senado: “Art. 306. (...) $§ 1^{\circ}$ No prazo máximo de vinte e quatro horas após a prisão em flagrante, o preso será conduzido à presença do juiz para ser ouvido, com vistas às medidas previstas no art. 310 e para que se verifique se estão sendo respeitados seus direitos fundamentais, devendo a autoridade judicial tomar as medidas cabíveis para preservá-los e para apurar eventual violação.
} 
aprovado com emendas pela Comissão de Direitos Humanos e Legislação Participativa e pela Comissão de Assuntos Econômicos, e atualmente aguarda a aprovação da Comissão de Constituição e Justiça. Consta também, que a Defensoria Pública da União já realizou Audiência Pública sobre o assunto e ajuizou uma Ação Civil em junho de 2014 perante a Justiça Federal do Amazonas para implementação da audiência de custódia no Brasil.

É evidente que esta reforma deve ser acompanhada da proibição da adoção da medida cautelar de ofício por parte do juiz.

Temos no direito comparado vários exemplos da utilização desta audiência prévia como método para decidir sobre a prisão preventiva. Já foram citados os casos da Itália (a richiesta di covalida dell'arresto o del fermo e a udienza di convalidaartigos 390 e 391 do Código de 1988), da Espanha (com a audiência prévia) e do Chile. Agraga-se os casos do Perú (que também não admite a prisão preventiva de ofício em seu Código de Processo Penal de $2004^{591}$ e condiciona a decisão de prisão preventiva à realização de uma audiência ${ }^{592}$ ) e da Colômbia (que também não admite a prisão

$\S 2^{\circ}$ A oitiva a que se refere o $\S 1^{\circ}$ não poderá ser utilizada como meio de prova contra o depoente $\mathrm{e}$ versará, exclusivamente, sobre a legalidade e necessidade da prisão; a prevenção da ocorrência de tortura ou de maus-tratos; e os direitos assegurados ao preso e ao acusado.

$\S 3^{\circ} \mathrm{A}$ apresentação do preso em juízo deverá ser acompanhada do auto de prisão em flagrante e da nota de culpa que lhe foi entregue, mediante recibo, assinada pela autoridade policial, com o motivo da prisão, o nome do condutor e os nomes das testemunhas.

$\S 4^{\circ}$ A oitiva do preso em juízo sempre se dará na presença de seu advogado, ou, se não o tiver ou não o indicar, na de Defensor Público, e na do membro do Ministério Público, que poderão inquirir o preso sobre os temas previstos no $\S 2^{\circ}$, bem como se manifestar previamente à decisão judicial de que trata 0 art. 310 deste Código."

${ }^{591}$ ARTíCULO ${ }^{268}$ Presupuestos materiales.- 1. El Juez, a solicitud del Ministerio Público, podrá dictar mandato de prisión preventiva, si atendiendo a los primeros recaudos sea posible determinar la concurrencia de los siguientes presupuestos...

${ }^{592}$ ARTíCULO 271 ${ }^{\circ}$ Audiencia y resolución.- 1. El Juez de la Investigación Preparatoria, dentro de las cuarenta y ocho horas siguientes al requerimiento del Ministerio Público realizará la audiência para determinar la procedencia de la prisión preventiva. La audiencia se celebrará con La concurrencia obligatoria del Fiscal, del imputado y su defensor. El defensor del imputado que no asista será reemplazado por el defensor de oficio.

2. Rige en lo pertinente, para el trámite de la audiencia lo dispuesto en el artículo $8^{\circ}$, pero La resolución debe ser pronunciada en la audiencia sin necesidad de postergación alguna. El Juez de la Investigación Preparatoria incurre en responsabilidad funcional si no realiza la audiência dentro del plazo legal. El Fiscal y el abogado defensor serán sancionados disciplinariamente si por su causa se frustra la audiencia. Si el imputado se niega por cualquier motivo a estar presente em la audiencia, será representado por su abogado o el defensor del oficio, según sea el caso. Em este último supuesto deberá ser notificado con la resolución que se expida dentro de las cuarenta y ocho horas siguientes a la conclusión de la audiencia.

3. El auto de prisión preventiva será especialmente motivado, con expresión sucinta de La imputación, de los fundamentos de hecho y de derecho que lo sustente, y la invocación de las citas legales correspondientes.

4. El Juez de la Investigación Preparatoria, si no considera fundado el requerimiento de prisión preventiva optará por la medida de comparecencia restrictiva o simple según el caso. 
preventiva de ofício em seu moderno Código de Processo Penal de $2004^{593}$ e, como o Chile, elegeu a audiência como método de tomada de todas as decisões ${ }^{594}$ ).

${ }^{593}$ Artículo 306. Solicitud de imposición de medida de aseguramiento. Modificado por el art. 59, Ley 1453 de 2011. El fiscal solicitará al juez de control de garantías imponer medida de aseguramiento, indicando la persona, el delito, los elementos de conocimiento necesarios para sustentar la medida y su urgencia, los cuales se evaluarán en audiencia permitiendo a la defensa la controversia pertinente. Escuchados los argumentos del fiscal, Ministerio Público y defensa, el juez emitirá su decisión. La presencia del defensor constituye requisito de validez de la respectiva audiencia.

594 Artículo 153. Noción. Las actuaciones, peticiones y decisiones que no deban ordenarse, resolverse o adoptarse en audiencia de formulación de acusación, preparatoria o del juicio oral, se adelantarán, resolverán o decidirán en audiencia preliminar, ante el juez de control de garantías. 


\section{BIBLIOGRAFIA ${ }^{595}$}

ABBAGNANO, Nicola. Dicionário de Filosofia. São Paulo: Martins Fontes. Trad. A.Bosi. 2007.

ALBUQUerQue, Paulo Pinto de. A reforma da Justiça Criminal em Portugal e na Europa. Coimbra: Amedina. 2003.

ALEXY, Robert. Constitucionalismo discursivo. $2^{\text {a }}$. ed. Porto Alegre: Livraria do Advogado. Trad. Luís Afonso Heck.. 2008.

Teoria dos Direitos Fundamentais. Trad. Virgílio Afonso da Silva. São Paulo: Malheiros. 2008.

ALIGHIERI, Dante. A Divina Comédia. Edição bilíngue. Trad. Italo Eugenio Mauro. São Paulo:34. 2004.

ALMEIDA, João Mendes de Almeida. O processo criminal brasileiro. V. I. $4^{\mathrm{a}}$. ed. Rio de Janeiro: Freitas Bastos S.A. 1959.

ALMEIDA, Joaquim Canuto Mendes de. Princípios fundamentais do processo penal. São Paulo: RT. 1973.

ALVES, Rogério Pacheco. O poder geral de cautela no processo penal. Revista da EMERJ, v. 6, n. 22, 2003. p. 276 a 306.

AMBOS, Kai; CHOUKR, Fauzi Hassan. A reforma do processo penal no Brasil e na América Latina. São Paulo: Método. 2001.

; LIMA, Marcellus Polastri. O processo acusatório e a vedação probatória: perante as realidades alemã e brasileira. Porto Alegre: Livraria do Advogado. 2009.

ARMENTA Deu, Teresa. Sistemas procesales penales: la justicia penal en Europa y América. Madrid: Marcial Pons. 2012.

\footnotetext{
595 De acordo com a Associação Brasileira de Normas Técnicas. NBR 6023. Citações do formato Kindle são anotadas da forma como aparecem do aparelho leitor de livros. 
BADARÓ, Gustavo Henrique Righi Ivahy. Correlação entre acusação e sentença. $2^{\mathrm{a}}$. ed. São Paulo: RT. 2009.

Processo Penal. $2^{\mathrm{a}}$.ed. Rio de Janeiro: Elsevier. 2014.

BAJER, Paula. Processo Penal e cidadania. Rio de Janeiro: Jorge Zahar. 2002.

BARNEWALL, Richard Vaughan; ALDERSON, Edward Hall. Reports of cases argued and determined in The Court of King's Bench: with tables of the names of the cases and the principal matters. A.Strahan:Dublin. 1818.

BARROS, Flaviane de Magalhães; MACHADO, Felipe Daniel Amorim. Prisão e Medidas Cautelares: nova reforma do processo penal - Lei $n^{\circ} 12.403 / 2011$. Belo Horizonte: Del Rey. 2011.

BASILIO, Paula Cunha. A prisão preventiva decretada de ofício no Processo Penal Brasileiro. Rio de Janeiro: Escola da Magistratura do Estado do Rio de Janeiro. 2013. Disponível em http://www.emerj.tjrj.jus.br/paginas/trabalhos conclusao/2semestre2013/trabalhos 22013/PaulaCu nhaBasilio.pdf. Acessado em 9 de setembro de 2014.

BAUMAN, Richard A. Crime and punishment in Ancient Rome. New York: Routledge. 2004.

BERRI, Giulio. Formulario delle misure cautelari personali e reali: esplicato comma per comma ed annotato con la giurisprudenza. Milano: Giuffrè. 2012.

BINDER, Alberto M. Derecho procesal penal. Tomo I: Hermenéutica del proceso penal. Buenos Aires: AdHoc. 2013.

BITTAR, Eduardo C. B. Metodologia da pesquisa juridical: teoria e prática da monografia para os cursos de direito. São Paulo: Saraiva. 2013.

BOBBIO, Norberto. Teoria do ordenamento jurídico. Brasília: Polis. 1990.

Era dos direitos. Trad. Regina Lyra. Rio de Janeiro: Elsevier. Trad. Regina Lyra. 2004. 
BONAVIDES, Paulo; ANDRADE, Paes. História constitucional do Brasil. $8^{\text {a }}$. ed. Brasília:OAB. 2006.

BRASIL. Ministério da Justiça. Sistema penitenciário no Brasil Fundo penitenciário nacional em números. 6 ${ }^{a}$. ed. Brasília: Departamento Penitenciário Nacional. 2012. Disponível em file:///C:/Users/F\%C3\%A1bio/Downloads/2012FunpenN\%C3\%BAmeros.pdf. Acessado em 16 de julho de 2014.

CALABRICH, Bruno; FISCHER, Douglas; PELELLA, Eduardo. (coord.) Garantismo penal integral: questões penais e processuais, criminalidade moderna e a aplicação do modelo garantista no Brasil. 2a . ed. Salvador: Jus Podivm. 2013.

CAMPOS, Francisco. O Estado Nacional: sua estrutura, seu conteúdo ideológico. Brasília: Senado Federal, Conselho Editorial, 2001.

CANARIS, Claus-Wilhelm. Pensamento sistemático e conceito de sistema na Ciência do Direito. Trad. A. Menezes Cordeiro. Lisboa: Fundação Calouste Gulbenkian. 1989.

CANOtilho, J.J. Gomes. Direito Constitucional e Teoria da Constituição. $7^{\mathrm{a}}$ ed. Coimbra: Almedina. 2003.

CARNELUTTI, Francesco. Cuestiones sobre el proceso penal. Trad. Santiago Sentís Melendo. Buenos Aires: Ediciones Jurídicas Europa-América. 1961.

CINTRA, Antonio Carlos de Araújo; GRINOVER, Ada Pellegrini; DINAMARCO, Cândido Rangel. Teoria Geral do Processo. 29ª ed. São Paulo: Malheiros. 2013.

CORDERO, Franco. Procedura penale. Nona edizione. Milano: Giuffrè.

COUTINHO, Jacinto Nelson de Miranda. O papel do novo juiz no processo penal. In (coord.) Crítica à teoria geral do direito processual penal. Rio de Janeiro e São Paulo: Renovar. 2001.

CRUZ, Rogério Schietti Machado. Com a palavra, as partes. Conteudo Juridico, BrasiliaDF: 19 maio $2009 . \quad$ Disponivel em: <http://www.conteudojuridico.com.br/?artigos\&ver=2.24012\&seo=1>. Acesso em: $15 \mathrm{de}$ setembro de 2014. 
CRYER, Robert; FRIMAN, HÅKAN; ROBINSON, Darryl; WILMSHURST, Elizabeth. An introdution to International Criminal Law and Procedure. Second Edition. Cambridge: Cambridge University Press. 2010.

DAMAŠKA, Mirjan R. The faces of justice and state authority: a comparative approach to the legal process. New Haven and London: Yale University Press. Kindle Edition. 1986. . Aspectos globales de la reforma del proceso penal. Reformas a la Justicia Penal en las Americas. Washington: Fundación para e Debido Proceso Legal. 1999. p. 37-57. Disponível em http://www.congresoson.gob.mx/docs_biblio/docBiblio_31.pdf. Acessado em 6 de agosto de 2014.

DAHL, Robert A. Sobre a democracia. Trad. Beatriz Sidou. Brasília: UNB. 2001.

DEMERCIAN, Pedro Henrique; MALULY, Jorge Assaf. Curso de processo penal. $9^{\mathrm{a}}$ ed. Rio de Janeiro: Forense. 2014.

DESCHNER, Karlheinz. God and fascists: the Vatican alliance with Mussolini, Franco and Pavelić. Trad. Richard Pepper. New York: Prometheus. 2013.

DIAS, Jorge de Figueiredo. Direito processual penal. $1^{\mathrm{a}}$ ed. Reimpressão. Coimbra: Coimbra. 2004.

DINAMARCO, Cândido Rangel. Instituições de Direito Processual Civil. V. II. $5^{\text {a }}$ ed. São Paulo: Malheiros. 2005.

DISNEY, A. R. A history of Portugal and the Portuguese Empire. Volume I: Portugal. Cambridge: Cambridge University Press. 2009.

DUCE, Mauricio; BAYTELMAN, Andrés. Evaluación de la reforma procesal penal: estado de uma reforma em marcha. Santiago: Universidad Diego Portales. Facultad de Derecho. 2003.

DUCE J., Mauricio; RIEGO R. Cristián. Proceso penal. Santiago: Editorial Juridica de Chile. 2007.

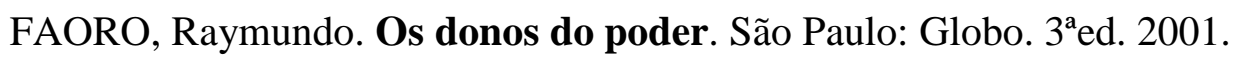


FAUSTO, Boris. Crime e cotidiano: a criminalidade em São Paulo (1880-1924). São Paulo: Brasiliense. 1984.

FERNANDES, Antonio Scarance. Teoria geral do procedimento e o procedimento no processo penal. São Paulo: Revista dos Tribunais. 2005.

- Funções e limites da prisão processual. Revista Brasileira de Ciências Criminais. Vol. 64. p. 239. jan. 2007.

Processo penal constitucional. São Paulo: RT. 7ª ed. 2012.

FERRAJOLI, Luigi. Derecho y razón: teoría del garantismo penal. Trad. Perfecto Andrés Ibáñez, Alfonso Ruiz Miguel, Juan Carlos Bayón Mohino, Juan Terradillos Basoco, Rocío Cantarero Bandrés. Madrid: Trotta. 1995.

FERREIRA, Dennis Aceti Brasil. A prisão preventiva de ofício e o processo penal tipo acusatório. Revista do Ministério Público. Rio de Janeiro: PGJ-RJ. n.8, p. 137-142, jul.dez., 1998.

FOUCAULT, Michel. Vigiar e punir: o nascimento da prisão. Petrópolis: Vozes. 1999.

A verdade e as formas jurídicas. Rio de Janeiro: Nau. $2^{\text {a }}$ ed. 2002.

GARNER, Bryan A. (Editor in Chief). Black's Law Dictionary. 9a ed. St. Paul: Thomson Reuters. 2009.

GASPARI, Elio. A ditadura escancarada. São Paulo: Companhia das Letras. 2002.

GAUER, Ruth Maria Chittó. Criminologia e sistemas jurídico-penais contemporâneos II. Porto $\quad$ Alegre. $2010 . \quad$ Disponível em http://www.pucrs.br/edipucrs/Crimin.eSist.Jurid.PenaisContemp.II.pdf. $\quad$ Acessado em 25/08/2014.

GIMENO Sendra, José Vicente. Manual de derecho procesal penal. 2a. ed. Madrid: Colex. 2010.

El Derecho Fundamental a un Proceso Acusatorio. In MACIEL, Adhemar Ferreira; SERRANO Gómez, Alfonso; MADLENER, Silma Marlice (coord.). Estudos de 
Direito Penal, Processual e Criminologia em homenagem ao Prof. Dr. Kurt Madlener. Brasília: Conselho da Justiça Federal, Centro de Estudo Judiciários. 2014.

; DÍAZ Martinez, Manuel. La prisión provisional y sus medidas alternativas. Madrid: Consejo General del Poder Judicial. 2005.

GOLDSCHMIDT, James. Problemas jurídicos y políticos del proceso penal. Barcelona: Bosch. 1935.

GOMES Filho, Antonio Magalhães. Presunção de inocência e prisão cautelar. São Paulo: Saraiva. 1991.

. Direito à prova no processo penal. São Paulo: RT. 1997.

Prefácio. In ZILLI, Marcos Alexandre Coelho. A iniciativa instrutória do juiz no processo penal. São Paulo: RT. 2003

. Presunção de inocência e prisão processual na Lei 12.403, de 2011. In LUCCA, Newton de; MEYER-PFLUG, Samantha Ribeiro; NEVES, Mariana Barboza Baeta (coord.). Direito Constitucional Contemporâneo: homenagem ao Professor Michel Temer. São Paulo: Quartier Latin. 2012.

GOMES, Luiz Flávio; MARQUES Ivan Luís (coord.). Prisão e medidas cautelares: comentários à Lei 12.403, de 4 de maio de 2011. 2a ed. São Paulo: Revista dos Tribubnais. 2011.

GRINOVER, Ada Pellegrini. Liberdades públicas e processo penal: as interceptações telefônicas. $2^{a}$. ed. São Paulo: RT. 1982.

HALL, Daniel E. Criminal law and procedure. 6ª ed. Clifton Park: Delmar. 2012.

HASSEMER, Winfried. Introdução aos fundamentos do Direito Penal. Tradução da $2^{\mathrm{a}}$ edição alemã por Pablo Rodrigo Alflen da Silva. Porto Alegre: Sergio Antonio Fabris. 2005.

HOBSBAWM, Eric. Age of extremes: the short twentieth century 1914-1991. London: Michael Joseph. 1994. 
HORKHEIMER, Max. Critical theory: selected essays. Trad. Matthew J. O'Connell e outros. New York: Continuum. 2002.

ILLUMINATI, Giulio. The accusatorial process from the Italian point of view. North Carolina Journal of International Law and Commercial Regulation. Chapel Hill, North Carolina, Volume 35 - Number 2, p. 297 to 318. Winter 2010. Disponível em http://www.law.unc.edu/journals/ncilj/issues/volume35/number-2-winter-2010/the-accusatorialprocess-from-the-italian-point-of-view/. Acessado em $1^{\circ}$ de junho de 2014.

JUSTIÇA. Direção e produção de Maria Augusta Ramos. Documentário. Brasil: produção independente, 2004. Disponível em: http://www.youtube.com/watch?v=_GrBKbZ6aPc. Acessado em 5 set. 2014.

KANT, Immanuel. The conflict of the faculties. Trad. Mary J. Gregor. New York: Abaris Books. 1979.

Critique of Pure Reason. Trad. P. Guyer, A.W.Wood. Cambridge: Cambridge University Press. 2000.

. Metaphysical foundations of natural science. In Theoretical philosophy after 1781. Cambridge: Cambridge University Press. Trad. Gary Hatfield; Michael Friedman; Henry Allison; Peter Heath. 2002.

KELSEN, Hans. Teoria Pura do Direito. Trad. João Baptista Machado. São Paulo: Martins Fontes.. 1999.

LARA, Silvia Hunold (org.) Ordenações Filipinas: Livro V. São Paulo: Companhia das Letras. 1999.

LEA, Henry Charles. A history of the inquisition of the Middle Ages. v. I. New York: Harper \& Brothers. Kindle Edition. 1887.

A history of the inquisition of Spain. New York: The Macmillan Company. 1906

LIMA, Marcellus Polastri. A tutela cautelar no processo penal. Rio de Janeiro: Lumen Juris. 2005. 
Manual de processo penal. $4^{\mathrm{a}}$. ed. Rio de Janeiro: Lumen Juris. 2009.

LOPES Jr., Aury. Prisões cautelares. São Paulo: Saraiva. 4a . ed. 2013.

Direito Processual Penal. 11ª Ed. São Paulo: Saraiva. 2014.

MACIÁ Gomez, Ramón; ROIG Altozano, Marina. El nuevo sistema de adopción de la medida cautelar de la prisión provisional. Actualidad penal. España. n.5, semana 29 enero a 4 febrero, p. 75-82. 1996. Disponível em http://www.ramonmacia.com/wpcontent/uploads/AP5-Prisi\%C3\%B3n-Provisional.pdf. Acessado em 26 de abril de 2014.

MAIER, Julio B. J. Derecho Procesal Penal. Tomo I: Fundamentos. $2^{\text {a }}$. ed. Buenos Aires: Editores Del Puerto. 2012.

; AMBOS, Kai; WOISCHNIK, Jan (coord.). Las reformas procesales penales em América Latina. Buenos Aires: AD-HOC. 2000.

MALAN, Diogo Rudge. Direito ao confronto no processo penal. Rio de Janeiro: Lumen Juris. 2009.

; MIRZA, Flávio (coord.) 70 anos de Código de Processo Penal brasileiro: balanço e perspectivas de reforma. Rio de Janeiro: Lumen Juris. 2011.

MARCÃO, Renato. Prisões cautelares, liberdade provisória e medidas cautelares restritivas. $2^{a}$ ed. São Paulo: Saraiva. 2012.

MARCHENA, Don J. (trad.). Manual de inquisidores: para uso de las inquisiciones de España y Portugal ó Compendio de la Obra titulada Directorio de Inquisidores, de Nicolao Eymerico. Mompeller: Imprenta de Feliz Aviñon.1821.

MARQUES, José Frederico. Elementos de direito processual penal. V.I. $3^{\text {a }}$ atualização. Campinas: Millennium. 2009.

MENDONÇA, Andrey Borges. Nova reforma do Código de Processo Penal: comentada artigo por artigo. $2^{\mathrm{a}}$ ed. São Paulo: Método. 2009.

. Prisão e outras medidas cautelares pessoais. São Paulo: Método. 2011. 
MOMMSEN, Teodoro. El derecho penal romano. Trad. P. Dorado. Madrid: La España Moderna. 1905.

MORAES, Maurício Zanoide de. Presunção de inocência no processo penal brasileiro: análise de sua estrutura normativa para a elaboração legislativa e para a decisão judicial. Rio de Janeiro: Lumen Juris. 2010.

MOTA, Carlos Guilherme; FERREIRA, Gabriela Nunes (coord.). Os juristas na formação do Estado-Nação brasileiro: 1850-1930. São Paulo: Saraiva. 2010.

MOUSOURAKIS, George. A legal history of Rome. London and New York: Routledge. 2007.

NUCCI, Guilherme de Souza. Código de Processo Penal comentado. $11^{\mathrm{a}}$ ed. São Paulo: RT. 2012.

NÚÑEZ Vásquez, J. Cristóbal. Tratado del proceso penal y del juicio oral. Tomo I: introducción al estudio del proceso penal. Santiago: Editorial Jurídica de Chile. 2003.

OLIVEIRA, Eugênio Pacelli de. Curso de Processo Penal. 18a. ed. São Paulo: Atlas. 2013.

O princípio acusatório e a nova prisão preventiva. Palestra proferida no $X$ Seminário de Direito Militar. Partes I e II. Superior Tribunal Militar. 30 de nov. de 2011. Disponível em http://www.youtube.com/watch?v=t09PqlA4cDs. Acessado em 2 de set. De 2014.

; FISCHER, Douglas. Comentários ao Código de Processo Penal e sua jurisprudência. $5^{\text {a }}$. ed. São Paulo: Atlas. 2013.

ORGA Larrés, José Carlos. Prisión provisional y principio acusatorio. Navarra: Legaltoday.com. Seção Penal. 7 de setembro de 2009. Disponível em: http://www.legaltoday.com/practica-juridica/penal/penitenciario/prision-provisional-y-principioacusatorio. Acesso em 20 de abril de 2014.

ORGANIZAÇÃO DAS NAÇÕES UNIDAS. Subcomitê de Prevenção da Tortura e outros Tratamentos ou Penas Cruéis, Desumanos ou Degradantes. Relatório sobre a visita ao Brasil do Subcomitê de Prevenção da Tortura e outros Tratamentos ou Penas Cruéis, 
Desumanos ou Degradantes. 08 de fevereiro de 2012. Disponível em http://www.onu.org.br/img/2012/07/relatorio SPT 2012.pdf. Acessado em 14 de abril de 2014.

ORGANIZAÇÃO DOS ESTADOS AMERICANOS. Comissão Interamericana de Direitos Humanos. Informe sobre el uso de la prisión preventiva en las Américas. OEA/Ser.L/V/II. Doc. 46/13. 30 diciembre 2013. Disponível em http://www.oas.org/es/cidh/ppl/informes/pdfs/Informe-PP-2013-es.pdf. Acessado em 16 de set. 2014.

PANZAVOLTA, Michele. Reforms and counter-reforms in the Italian struggle for an accusatorial criminal law system. North Carolina Journal of International Law and Commercial Regulation. Chapel Hill, North Carolina, Volume 30 - Number 3, p. 577 to 624. Spring $2005 . \quad$ Disponível em http://www.law.unc.edu/journals/ncilj/issues/volume30/number-3-spring-2005/reforms-andcounterreforms-in-the-italian-struggle-for-an-accusatorial-criminal-law-system/. Acessado em $1^{\circ}$ de junho de 2014.

PESSOA, Vicente Alves de Paula, Cons. Codigo do Processo Criminal de Primeira Instancia do Brazil. Rio de Janeiro: Jacintho Ribeiro dos Santos. 1899.

PRADO, Geraldo. Sistema acusatório: a conformidade constitucional das leis processuais penais. 4. ed. Rio de Janeiro: Lumen Juris, 2006.

PROJETO "BRASIL: NUNCA MAIS". O regime militar. São Paulo: Arquidiocese de São Paulo. 1985.

RAMOS, André de Carvalho. Curso de direitos humanos. São Paulo: Saraiva. 2014.

RIEGO, Cristián; DUCE, Mauricio (directores de la investigación y editores). Prisión preventive y reforma procesal penal en América Latina: evaluación y perspectivas. Santiago: Centro de Estudios de Justicia de las Americas (CEJA). 2009.

RODRÍGUEZ Vega, Manuel. Discrecionalidad del Ministerio Público y objeto del juicio abreviado. Revista de Derecho de la Pontificia Universidad Católica de Valparaíso. Volume XXXVI. Valparaíso, Chile, 2011, 1er Semestre. p. 495 - 529. 
ROSA, Alexandre Morais da. Guia compacto do processo penal conforme a teoria dos jogos. $2^{\text {a }}$. ed. Rio de Janeiro: Lumen Juris. 2014.

RUSSELL, Bertrand. A history of western philosophy. New York: Simon and Schuster. 1945.

SAAD, Marta; MALAN, Diogo Rudge. Origens históricas dos sistemas acusatório e inquisitivo. Revista dos Tribunais. Vol. 842. p. 413. dez. 2005.

SALLES, José Roberto da Cunha. Foro penal: teoria e prática do Processo Criminal brasileiro. Volume I: do Poder Judicial. Rio de Janeiro: B.L. Garnier. 1882.

SAMAHA, Joel. Criminal procedure. $8^{\mathrm{a}}$. ed. Belmont: Wadsworth. 2012.

SCHWARTZ, Bernard. The unpublished opinions of the Warren Court. New York: Oxford University Press. 1985.

A history of the Supreme Court. New York: Oxford University Press. Kindle Edition.1995.

SKLANSKY, David Alan. Anti-inquisitorialim. 122 HARVARD LAW REVIEW 1634 2008-2009.

TAVOLARI Oliveros, Raúl. Instituciones del nuevo proceso penal: cuestiones y casos. Santiago: Jurídica de Chile. 2005.

TERRILL, Richard J. World Criminal Justice systems: a survey. Seventh Edition. New Providence, NJ: Matthew Bender \& Company, Inc. 2009.

THEODORO Júnior, Humberto. Curso de direito processual civil: processo de execução e cumprimento da sentença, processo cautelar e tutela de urgência. Volume II. $42^{\mathrm{a}}$. ed. Rio de Janeiro: Forense. 2008.

TOCQUEVILlE, Alexis de. Democracy in America. V. I. Trad. Henry Reeve, Esq. $4^{\mathrm{a}}$. ed. New York: J. \& H. G. Langley. 1841.

TOURINHO Filho, Fernando da Costa. Processo penal. V. 3. $34^{\mathrm{a}}$. ed. São Paulo: Saraiva. 2012. 
VILLA, Marco Antonio. A história das Constituições brasileiras: 200 anos de luta contra o arbítrio. São Paulo: Leya. 2011.

WALMSLEY, Roy. World Pre-trial/Remand Imprisonment List (second edition). London: International Centre for Prison Studies. 2014. Disponível em http://www.prisonstudies.org/sites/prisonstudies.org/files/resources/downloads/world_pretrial_imprisonment_list_2nd_edition_1.pdf . Acessado 5 de setembro de 2014.

WEBER, Max. Economy and society: an ouline of interpretive sociology. Guenther Roth. Claus Wittich (ed.). Berkeley, Los Angeles, London: University of California Press. 1978. WOLKMER, Antônio Carlos. História do Direito no Brasil. $3^{\text {a }}$. ed. Rio de Janeiro: Forense. 2003. (org.) Fundamentos de História do Direito. Belo Horizonte: Del Rey. 2006. 